\author{
Universidade de São Paulo \\ Faculdade de Filosofia, Letras e Ciências Humanas \\ Departamento de Geografia
}

\title{
COREMÁTICA INSULAR
}

Uma teoria para a modelização gráfica de ilhas e arquipélagos

O exemplo da ilha Montão de Trigo (SP)

Versão corrigida

São Paulo

2017 
Matheus Sartori Menegatto

\section{COREMÁTICA INSULAR}

Uma teoria para a modelização gráfica de ilhas e arquipélagos

O exemplo da ilha Montão de Trigo (SP)

Dissertação de Mestrado apresentada ao Programa de Pós-Graduação em Geografia Humana do Departamento de Geografia da Faculdade de Filosofia, Letras e Ciências Humanas da Universidade de São Paulo para obtenção do título de Mestre em Ciências (Geografia Humana)

Orientadora: Profa. Dra. Fernanda Padovesi Fonseca

São Paulo 
Autorizo a reprodução e divulgação total ou parcial deste trabalho, por qualquer meio convencional ou eletrônico, para fins de estudo ou pesquisa, desde que citada a fonte.

Catalogação na Publicação

Serviço de Biblioteca e Documentação

Faculdade de Filosofia, Letras e Ciências Humanas da Universidade de São Paulo

M541c Menegatto, Matheus Sartori

Coremática Insular: Uma teoria para a modelização gráfica de ilhas e arquipélagos; o exemplo da ilha Montão de Trigo (SP) / Matheus Sartori Menegatto; orientadora Fernanda Padovesi Fonseca. São Paulo, 2017. 192 f.

Dissertação (Mestrado) - Faculdade de Filosofia, Letras e Ciências Humanas da Universidade de São Paulo. Departamento de Geografia. Área de concentração: Geografia Humana.

1. Cartograma. 2. Ilhas. 3. Geografia. 4. Geometria. 5. São Sebastião. I. Fonseca, Fernanda Padovesi, orient. II. Título. 
Matheus Sartori Menegatto

\title{
COREMÁTICA INSULAR
}

Uma teoria para a modelização gráfica de ilhas e arquipélagos

O exemplo da ilha Montão de Trigo (SP)

\author{
Banca Examinadora:
}

Profa. Dra. Fernanda Padovesi Fonseca

Professora Orientadora

Programa de Pós-Graduação em Geografia Humana

FFLCH - USP

Prof. Dr. Hervé Émilien René Théry

Programa de Pós-Graduação em Geografia Humana FFLCH - USP

Profa. Dra. Sueli Angelo Furlan

Programa de Pós-Graduação em Geografia Física

FFLCH - USP

Prof. Dr. Eduardo Paulon Girardi

Programa de Pós-Graduação em Geografia

FCT - UNESP (Campus Presidente Prudente) 
A Santo Antônio 


\section{AGRADECIMENTOS}

Tudo aquilo que fazemos e que adquire correspondência concreta no mundo humano, permeado de seus significados, é uma obra, seja um livro, uma casa ou uma história. Com efeito, toda obra é feita pelos homens e para os homens, um coletivo, e nunca por um único homem e para um único homem, individualmente. Isso porque não há legado nem sentido social em algo que não se compartilha. Inclusive um livro de memórias; uma só pessoa pode escrevê-lo, mas as memórias, mesmo que suas, são construídas na companhia dos outros, segundo aquilo que lhe fizeram, segundo o que ela lhes fez. Até no caso dos eremitas, muitos deles privando-se da companhia de outrem por dias, meses ou anos, sua obra é mais que sua vida, algo individual; é seu exemplo de vida, algo coletivo.

Assim, tomemos este trabalho por uma obra. Que seja singela, ela não constitui uma simples

derivação de meu esforço. É, antes, feita para e pelos outros homens, que me formaram desde o nascimento até hoje, em todos os sentidos, em todas as dimensões. É com esta percepção que agradeço imensamente por tudo.

A forma e o conteúdo deste trabalho, devo à minha orientadora, Profa. Dra. Fernanda Padovesi Fonseca.

A capacidade de discriminar o essencial do acessório, aos Profs. Drs. Sueli Angelo Furlan e Hervé Théry, bem como aos orientandos da Profa. Fernanda.

A oportunidade de estudar, à Universidade de São Paulo (USP) e a todos os cidadãos que a custeiam mediante a nobreza e a honestidade de seu trabalho.

Os subsídios para os mapas e para frequentar as disciplinas do mestrado, à Empresa Paulista de Planejamento Metropolitano S.A. (Emplasa).

O conhecimento do objeto de estudo, aos moradores do Montão.

A consciência, aos meus pais Adriana e João, ao meu irmão Leonardo, ao Douglas, ao Guilherme, às minhas avós Maria, Romilda e Nazareth, aos meus padrinhos, aos meus tios e primos e aos demais amigos e familiares.

A vida, a Deus. 
Enlurados num bloco de pedra, tudo quanto para nós é sensação de todos os instantes, neles é saudade e desejo. Cessam os ouvidos de ouvir a música da terra, rumorejo de arvoredo, vozes amigas, barulho de rua, as mil e uma notas duma polifonia que nós sabemos que o é, e encantadora, unicamente quando a segregação prolongada nos ensina a lhe conhecer o valor. Cessam os olhos de rever a imagem que desde a meninice lhe são habituais. Para os ouvidos, só há ali, dia e noite, ano e ano, o marulho das ondas a chicotadas no enrocamento da torre; e, para a vista, a eterna massa que ondula, ora torva, ora azul. Variantes únicas, as velas que passam de largo, donairosas como garças, ou os transatlânticos penachados de fumo. Figura a vida de um homem arrancado à querência e assim posto, qual triste galé, dentro duma torre de pedra, grudada como craca a um ilhéu. Terá poesia de longe; de perto, é alucinante.

Monteiro Lobato. Os faroleiros. 


\section{Coremática Insular: Uma teoria para a modelização gráfica de ilhas e arquipélagos; o exemplo da ilha Montão de Trigo (SP)}

\section{Resumo}

O objetivo principal deste trabalho é demonstrar a especificidade do universo insular. Para tal, os conceitos de insularidade, maritimidade, litoralismo, ilheidade e condição arquipelágica foram elencados de modo a abarcar fatores comuns no âmbito da miríade de possibilidades que as ilhas são capazes de ensejar. O intento central foi, assim, explorar esses conceitos por intermédio de representações gráficas capazes de transcender a simples analogia com a realidade, típica dos mapas. Trata-se, pois, do método da Coremática, desenvolvido pelo geógrafo francês Roger Brunet na busca de uma argumentação feita não somente pelas palavras, mas pelas imagens. A princípio, com as possibilidades de representação geométrica existentes, é possível compor uma série de figuras estruturantes ou basilares que, combinada ou individualmente, são capazes de expressar as dinâmicas fundamentais de determinado espaço geográfico. Com efeito, lançou-se mão do método coremático para demonstrar a especificidade da forma insular, tendo, como estudo de caso, Montão de Trigo, uma ilha localizada no litoral norte do estado de São Paulo. Empregou-se, assim, uma modelização gráfica da ilha, a partir da qual se foi capaz de identificar determinados traços distintivos, tais quais a relação terra-mar; as ligações internas e externas; as centralidades intrainsulares; as formas de compartimentar o território; o direito de propriedade e o direito de uso do espaço insular; os graus de antropização; e, finalmente, o papel da influência marítima no assentamento humano.

Palavras-Chave: Coremática; modelização gráfica; ilha; insularidade; Montão de Trigo (SP). 
Chorématique, islands and archipelagoes: A theory for graphical modelling; the example of Montão de Trigo Island (SP)

\begin{abstract}
This work shows the specific feature of the islands. To do so, we used the concepts of insularity, maritime dimension, coastal condition, sense of belonging to an island and archipelagic nature, that can describe different situations related to the islands. The main idea was to present these concepts by using some graphical depictions, which can go beyond the simple analogy with geographical reality that the maps usually present; by using, therefore, a method that could argue with images instead of words: the Chorématique, developed by the French geographer Roger Brunet. Firstly, with the current representation possibilities in terms of geometry, Brunet proposed some basic or structural images that can be used (separately or jointly) in different situations to show the most important aspects of a region. By applying this method to demonstrate the island distinctiveness, we created some basic images as well as Brunet done. Then, we presented a graphic model that shows the essential geography of Montão de Trigo, a small island in the northern coast of São Paulo State, Brazil. Among all the features of the island, there are different types of phenomena: relationships between ocean and land; domestic and foreign linkages; center places; natural and human regions; ownership and rights of use the land; degrees of human intervention; and, finally, the maritime influences in the process of human settlement.
\end{abstract}

Keywords: Chorématique; graphical modelling; island; insularity; Montão de Trigo (SP). 


\section{LISTA DE QUADROS}

Quadro 1. Quadro descritivo dos mapas elaborados .................................... 35-38

Quadro 2. Coremas propostos por Brunet (2001) ......................................... 53

Quadro 3. Corotipos dos espaços insulares ........................................... 120 


\section{LISTA DE FIGURAS}

Figura 1. Mapa dos pontos de controle e coleta de dados em campo, na ilha Montão de Trigo .... 32 Figura 2. Modelos gráficos de ocupação e integração territorial da Nova Zelândia (COGNARD,

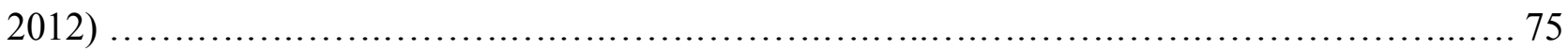

Figura 3. Modelos gráficos da ilha de Córsega (BRUNET, 2004) …........................ 76

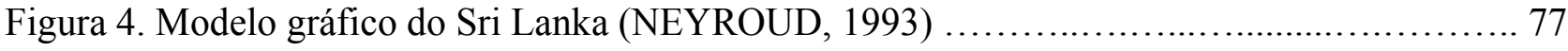

Figura 5. Modelo gráfico do Japão no contexto do fluxo mundial de capitais e mercadorias

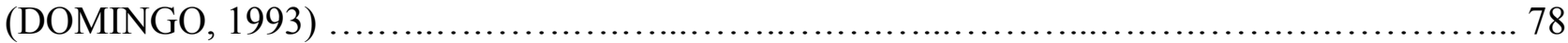

Figura 6. Modelos gráficos de análise e síntese retratando a Malásia (KONINCK e THÉRY, 1989)

Figura 7. Modelos gráficos de análise e síntese retratando a ilha de Socotorá (GUÉBOURG, 2000)

Figura 8. Modelos gráficos da ilha de Tenerife (JADÉ, 2000) ................................ 81

Figura 9. Modelos gráficos da difusão do turismo no arquipélago de Comores (GAY, 2001) ...... 82

Figura 10. Modelo gráfico da ilha de Reunião (JAUZE, 1996) ................................. 83

Figura 11. Modelos gráficos comparativos de Guadalupe e Martinica (CALMONT e VASSOIGNE, 1999)

Figura 12. Modelo gráfico da organização do espaço turístico na ilha de Reunião (BOUCHET e

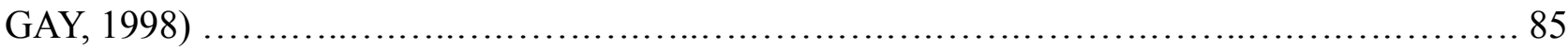

Figura 13. Modelos gráficos comparativos das ilhas de Reunião e Maurício (KNAFOU, 1988) ... 85

Figura 14. Modelo gráfico da ilha de Guadalupe (BRUNET, 1986) …......................... 86

Figura 15. Modelo gráfico da ilha de Reunião (GUÉBOURG e THÉRY, 1988) ................... 86

Figura 16. Modelo gráfico de Ubatuba e suas ilhas (PANIZZA et al., 2004) ..................... 87

Figura 17. Modelo gráfico da ilha Upaon-Açu (MA) ....................................... 88

Figura 18. Modelos gráficos das ilhas de Cuba e Madagascar .................................... 89

Figura 19. Modelo gráfico de Bornéu ..................................................... 90

Figura 20. Modelo gráfico de São Tomé e Príncipe ........................................... 91

Figura 21. Modelos gráficos de Nauru e da federação micronésia $\ldots \ldots \ldots \ldots \ldots \ldots \ldots \ldots \ldots \ldots \ldots . \ldots 92$

Figura 22. Modelo gráfico das ilhas Sociedade (Polinésia Francesa) ............................ 93

Figura 23. Modelos gráficos do Havaí, das Canárias e da ilha de Santa Helena .................... 94

Figura 24. Modelos gráficos da Ilha Comprida (município, SP) e de Funafuti (Tuvalu) .......... 95

Figura 25. Modelos gráficos das ilhas de Páscoa e da Islândia ................................... 96

Figura 26. Modelo gráfico da ilha de Santiago (Cabo Verde) e de Marajó (PA) ..................... 97 


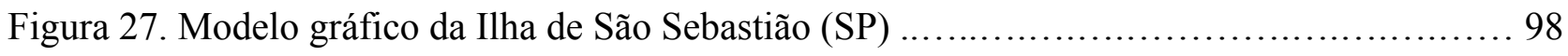

Figura 28. Modelos gráficos de Hong Kong e Tristão da Cunha .................................. 99

Figura 29. Modelo gráfico das ilhas Maurício .............................................. 100

Figura 30. Modelos gráficos de Florianópolis (SC), Fernando de Noronha (PE) e Ilha do Sul

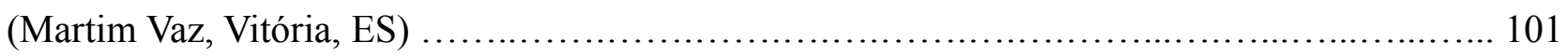

Figura 31. Modelo gráfico da ilha de Santo Antão (Cabo Verde) ............................ 102

Figura 32. Modelo gráfico do arquipélago japonês ....................................... 103

Figura 33. Modelo gráfico da ilha de Vitória (ES) ....................................... 104

Figura 34. Modelo gráfico da ilha de Santa Lúcia ........................................ 105

Figura 35. Modelos gráficos das ilhas de Itaparica (BA) e São Vicente (SP) ..................... 106

Figura 36. Modelos gráficos da Macaronésia lusófona ................................... 107

Figura 37. Modelos gráficos de Malta e Cabo Verde ......................................... 108

Figura 38. Modelo gráfico da ilha do Mosqueiro (Belém, PA) ............................... 109

Figura 39. Modelo gráfico da Groenlândia ............................................. 110

Figura 40. Modelo gráfico do Chipre ..................................................... 111

Figura 41. Modelos gráficos de Singapura e Montão de Trigo (SP) ............................. 112

Figura 42. Modelo gráfico da Ilha Grande (RJ) ....................................... 113

Figura 43. Modelo gráfico da ilha da Queimada Grande (SP) .............................. 114

Figura 44. Modelo gráfico das ilhas paulistas do Mar Virado, das Couves, Comprida (Ubatuba) e Anchieta ............................................................................... 115

Figura 45. Modelo gráfico do arquipélago de Comores .................................. 116

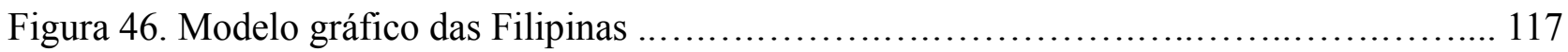

Figura 47. Modelo gráfico das escalas e contextos regionais de Aruba ...........................118

Figura 48. Modelo gráfico das ilhas de Man e do Canal ........................................ 119

Figura 49. Ortofotografia da ilha Monte de Trigo ......................................... 122

Figura 50. Mapa de localização da ilha Monte de Trigo ................................... 123

Figura 51. Fotografia da ilha Monte de Trigo vista da Barra do Una, São Sebastião .............. 124

Figura 52. Fotografia da ilha Monte de Trigo vista do barco que usamos na travessia partindo da

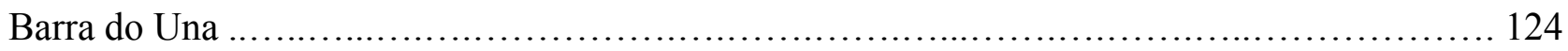

Figura 53. Mapa planialtimétrico de Monte de Trigo .................................... 126

Figura 54. Fotografia da Vila dos Pescadores, localizada no platô ........................... 127

Figura 55. Fotografia do ponto de atracamento no Sítio de Lá ............................ 127

Figura 56. Mapa orobatimétrico e perfil topográfico de Monte de Trigo ........................ 129

Figura 57. Mapa litológico de Monte de Trigo ............................................. 131 
Figura 58. Mapa de unidades fisiográficas e formas de vertente de Monte de Trigo 133

Figura 59. Fotografia da Ponta Negra

Figura 60. Fotografia de escolhos próximos ao costão das Tocas

Figura 61. Croqui climático esquemático de Monte de Trigo

Figura 62. Mapa de abastecimento de água e energia elétrica em Monte de Trigo

Figura 63. Fotografia de painel fotovoltaico na Vila dos Pescadores ....

Figura 64. Fotografia de caixa d'água na Vila dos Pescadores

Figura 65. Croqui pedológico esquemático de Monte de Trigo ....

Figura 66. Fotografia da Lage, maior dos escolhos marinhos próximos à Monte de Trigo

Figura 67. Avifauna dos escolhos adjacentes à ilha Monte de Trigo

Figura 68. Mapa da atividade pesqueira nas regiões de Bertioga e São Sebastião 146

Figura 69. Fotografia do atracadouro com suas estivas características

Figura 70. Fotografia de rede de pesca utilizada pelos monteiros

Figura 71. Mapa de uso e cobertura das terras (vegetação natural e afloramentos rochosos) em Monte de Trigo 151

Figura 72. Mapa de uso e cobertura das terras (tratos antrópicos) em Monte de Trigo 152

Figura 73. Mapa de uso e cobertura das terras em Monte de Trigo segundo o vocabulário caiçara

Figura 74. Fotografia de coqueiro na Vila dos Pescadores 154

Figura 75. Fotografia de bambuzal na Vila dos Pescadores 154

Figura 76. Fotografia de cão, uma das espécies introduzidas em Monte de Trigo 155

Figura 77. Fotografia de galinhas, patos e gansos, também espécies introduzidas 155

Figura 78. Fotografia de fanerófitos com lianas, vistos da trilha 156

Figura 79. Fotografia da serrapilheira florestal 156

Figura 80. Fotografia do costão com presença de espécies vegetais nativas (de porte herbáceo e arbóreo) e introduzidas (cana-de-açúcar, coqueiros)

Figura 81. Fotografia de porção íngreme do terreno, com campos graminosos e árvores de menor porte 157

Figura 82. Fotografia de espécies rupícolas e saxícolas 158

Figura 83. Fotografia de afloramentos de rocha nua, litófitos e fanerófitos 158

Figura 84. Fotografia do pontão úmido da ilha com bromeliáceas 159

Figura 85. Fotografia de detalhe da flora do cume de Monte de Trigo 159

Figura 86. Fotografia da vegetação dos lajeados de altitude 160

Figura 87. Fotografia de matacão próximo ao topo aguçado da ilha, com presença de cactáceas .160 
Figura 88. Fotografia de picada íngreme aberta próximo ao costão de Monte de Trigo 162

Figura 89. Fotografia da torre de transmissão localizada junto ao pico 162

Figura 90. Mapa das trilhas e picadas de Monte de Trigo, com algumas marcações de tempo de deslocamento 163

Figura 91. Mapa de atividades e equipamentos sociais e econômicos de Monte de Trigo 165

Figura 92. Fotografia da escola, na Vila dos Pescadores 166

Figura 93. Fotografia de roça próxima à escola 166

Figura 94. Fotografia da Igreja Evangélica Assembleia de Deus, única edificação religiosa de funcionamento corrente na Vila dos Pescadores 167 Figura 95. Fotografia dos monteiros. No caso, neto e avó. O chapéu e o tapete circular, feitos a partir da folha de bananeira, são exemplos do artesanato desenvolvido na ilha 167

Figura 96. Mapa de usos do território em Monte de Trigo 169

Figura 97. Fotografia da construção em madeira na Vila dos Pescadores 170

Figura 98. Fotografia de banheiros externos às moradias 170

Figura 99. Modelos gráficos de análise e síntese retratando a ilha Monte de Trigo 174

Figura 100. Retrato cronocoremático da ilha Monte de Trigo 175 


\section{SUMÁRIO}

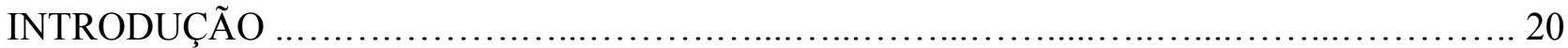

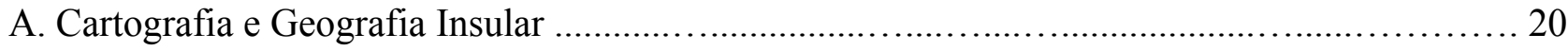

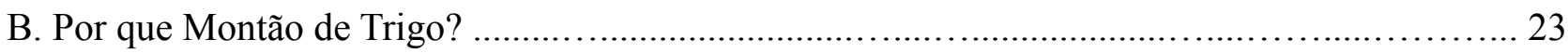

C. Há alguma especificidade geográfica nas ilhas e nos arquipélagos? .......................... 25

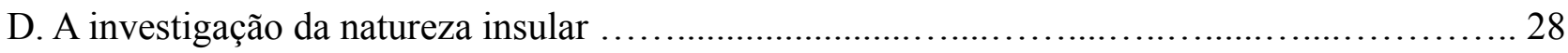

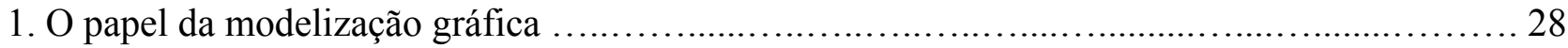

2. Dos nexos entre Geografia, Geometria e Cartografia aos corotipos insulares .................... 30

3. Modelos gráficos de Montão de Trigo: produtos de um processo ............................. 31

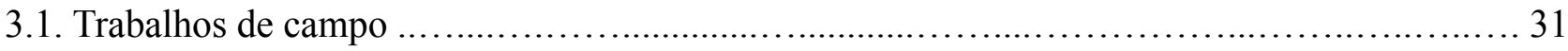

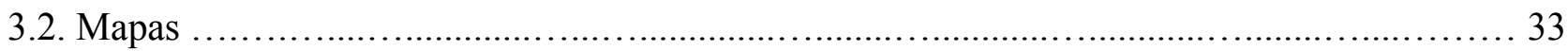

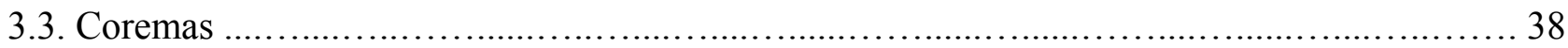

CAP. I. UMA GRAMÁTICA PARA REPRESENTAR O ESPAÇO GEOGRÁFICO ............... 40

A. Espaço geométrico, espaço geográfico ..................................................... 40

B. Cartografia e espaço de representação .................................................... 43

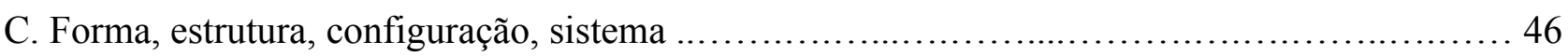

D. Modelos e modelização gráfica .................................................... 49

E. Coremática: um vínculo entre as vertentes nomotética e idiográfica da Geografia .............. 51

CAP. II. LITORALISMO, MARITIMIDADE E INSULARIDADE ............................ 57

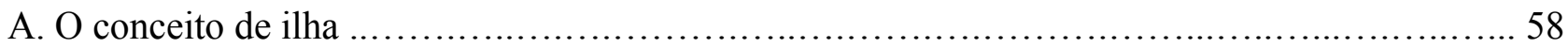

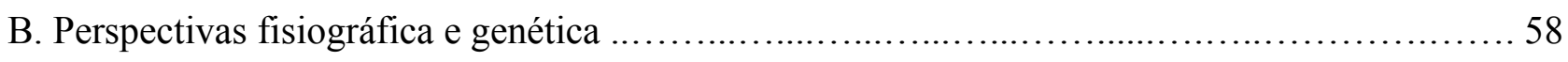

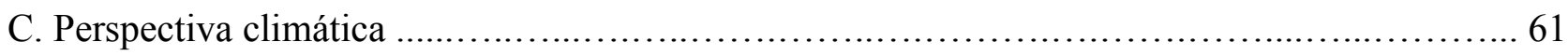

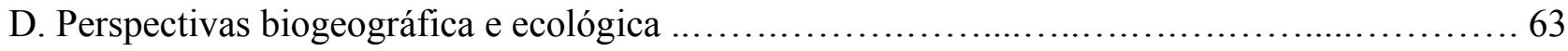

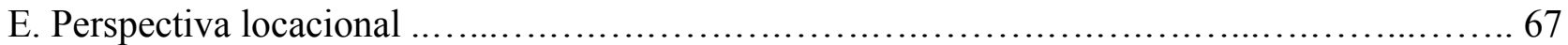

F. Perspectivas perceptiva e cultural ............................................................. 68

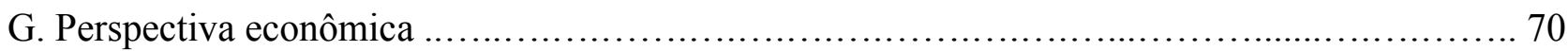

H. Perspectivas social e demográfica ...................................................... 71

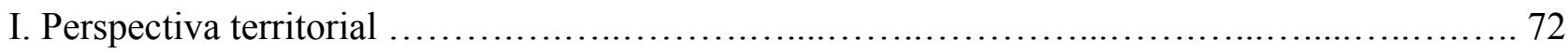


A. Exemplos da Revista M@ppemonde ..................................................... 75

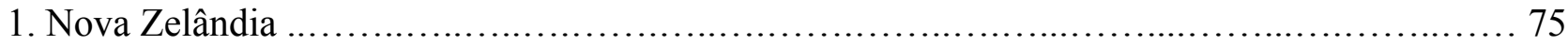

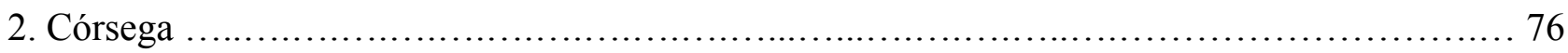

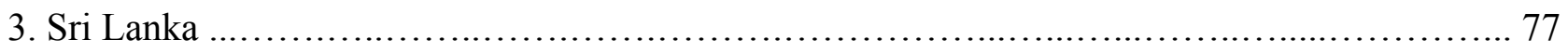

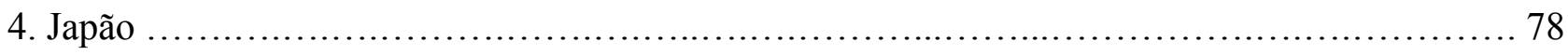

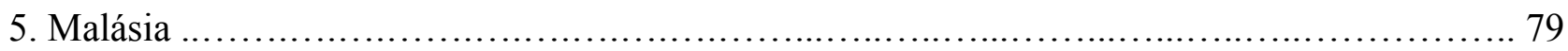

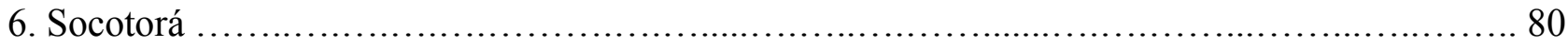

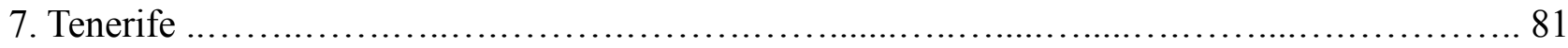

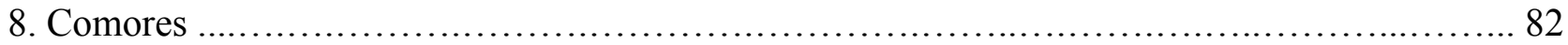

9. Maurício, Reunião, Martinica e Guadalupe ............................................. 83

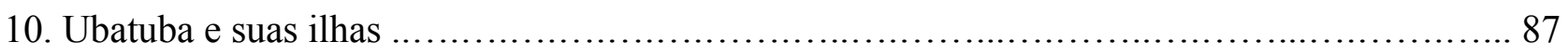

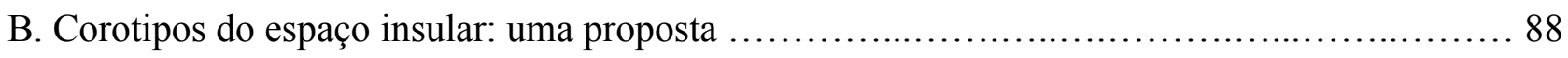

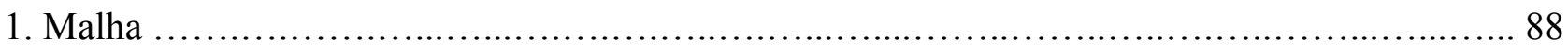

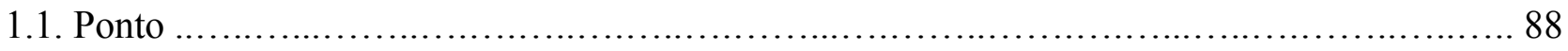

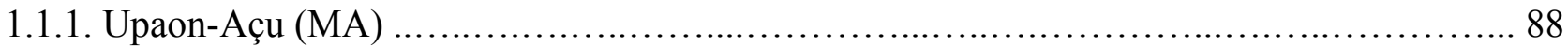

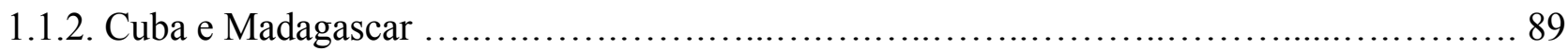

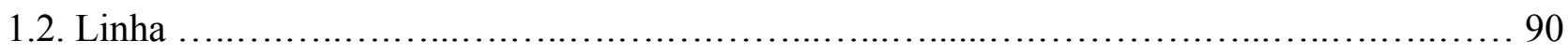

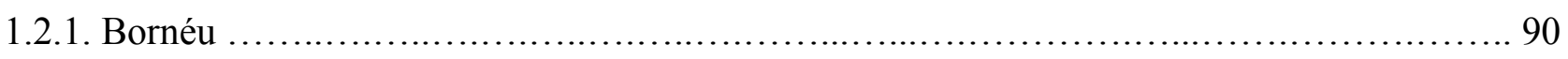

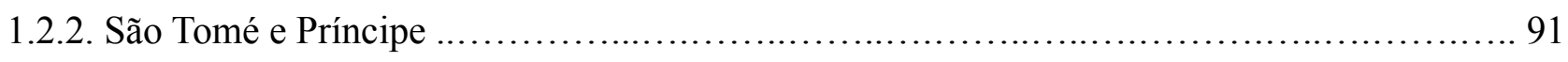

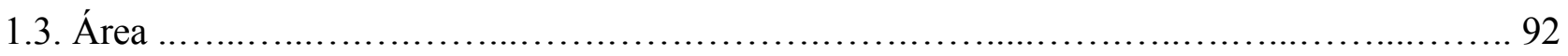

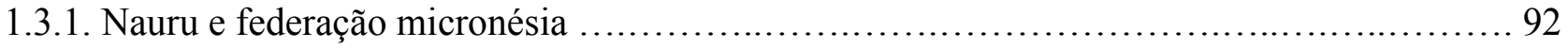

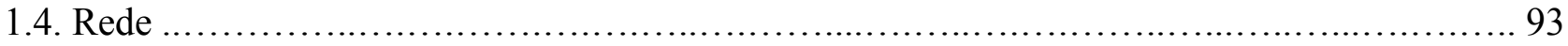

1.4.1. Sociedade (Polinésia Francesa) ......................................................... 93

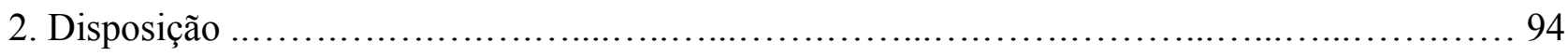

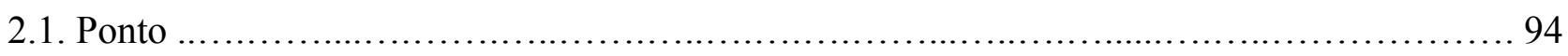

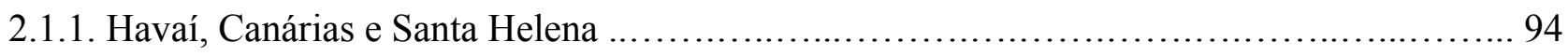

2.1.2. Ilha Comprida (município, SP) e Funafuti (Tuvalu) .................................. 95

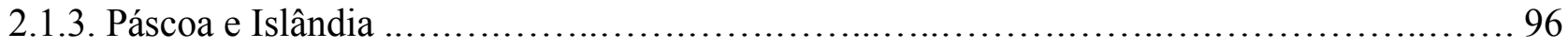

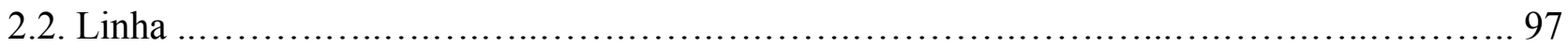

2.2.1. Marajó (PA) e Santiago (Cabo Verde) ............................................. 97

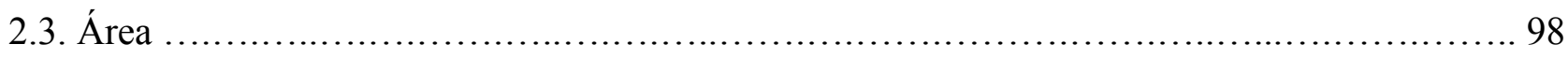

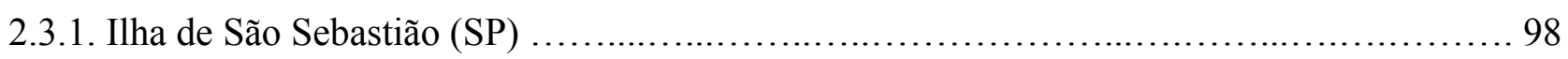

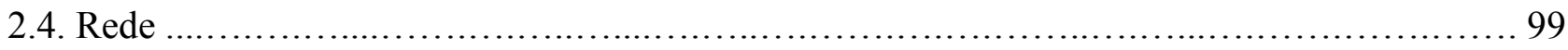


2.4.1. Hong Kong e Tristão da Cunha ........................................................ 99

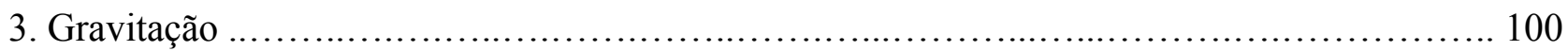

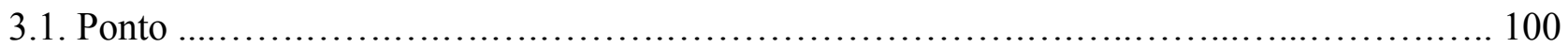

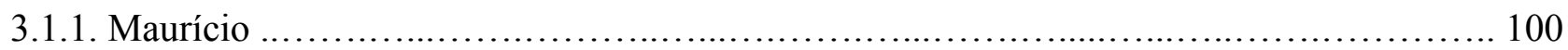

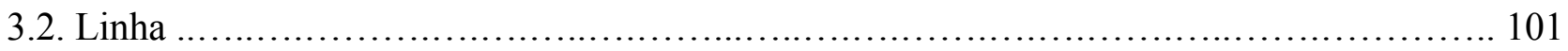

3.2.1. Florianópolis (SC), Fernando de Noronha (PE) e Ilha do Sul (Martim Vaz, Vitória, ES) ... 101

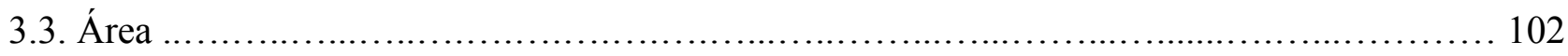

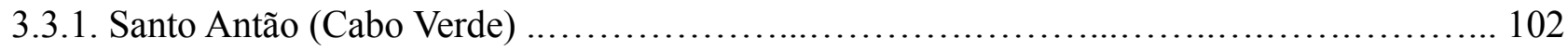

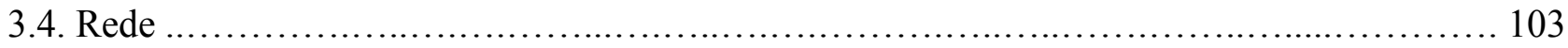

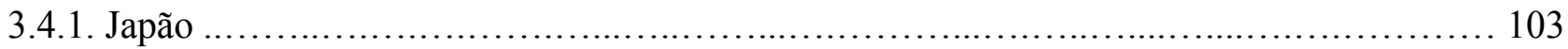

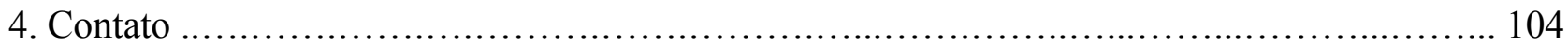

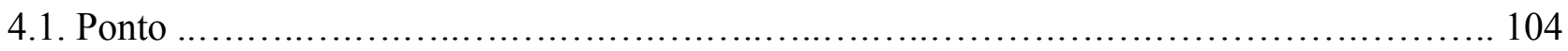

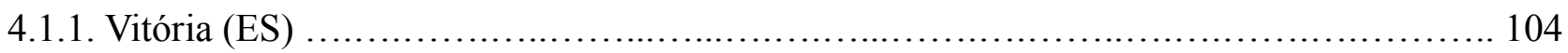

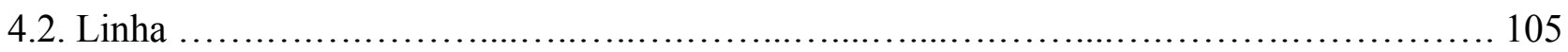

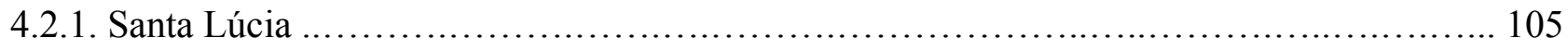

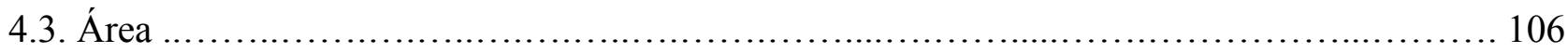

4.3.1. Itaparica (BA) e São Vicente (SP) ................................................... 106

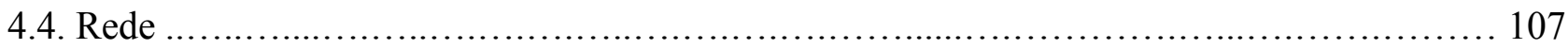

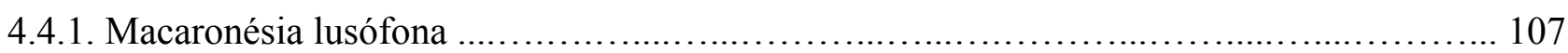

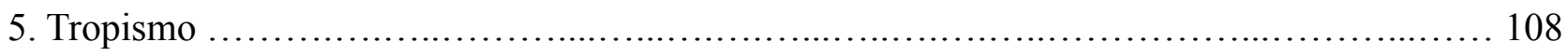

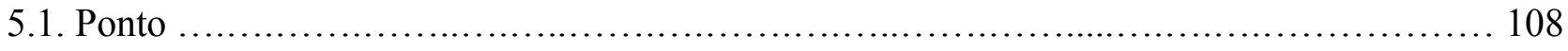

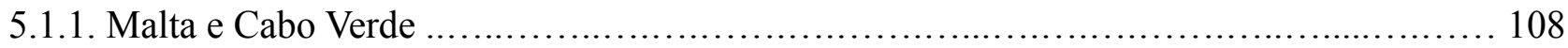

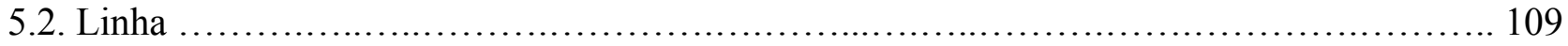

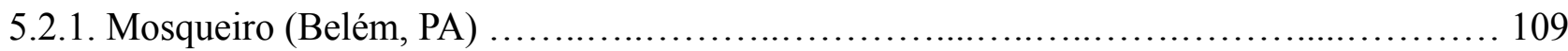

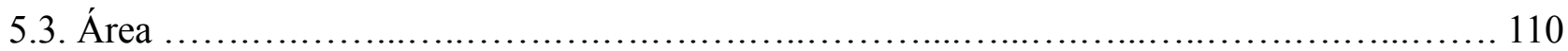

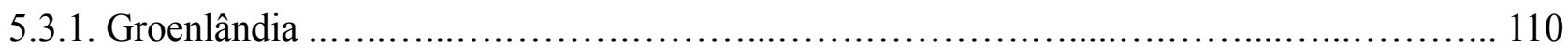

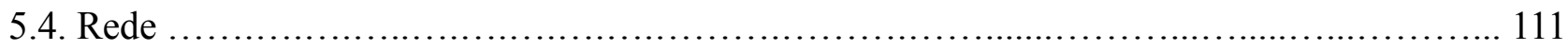

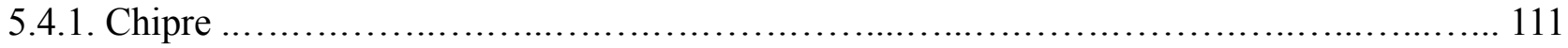

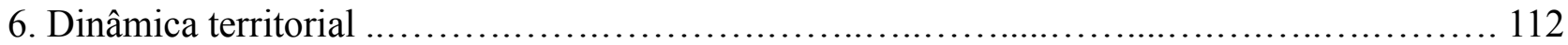

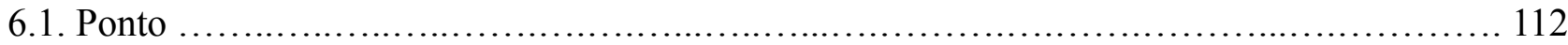

6.1.1. Singapura e Montão de Trigo (SP) ............................................... 112

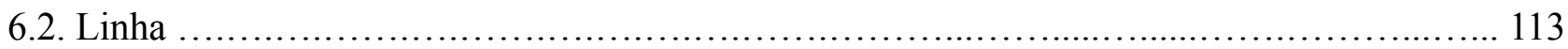

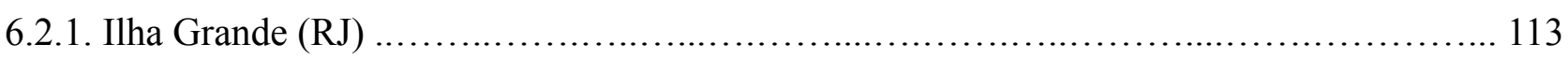

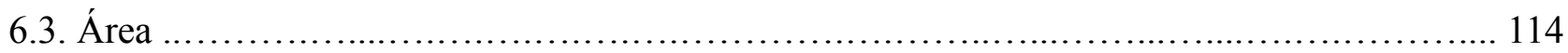




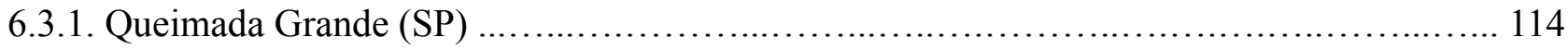

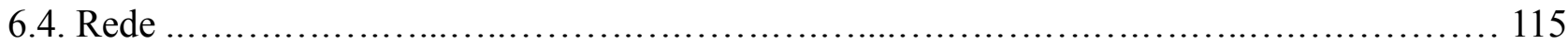

6.4.1. Ilhas paulistas do Mar Virado, das Couves, Comprida (Ubatuba) e Anchieta .............. 115

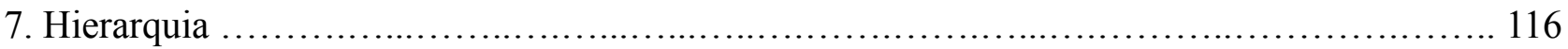

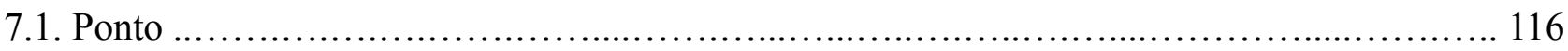

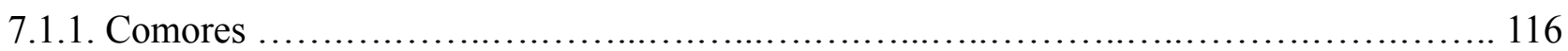

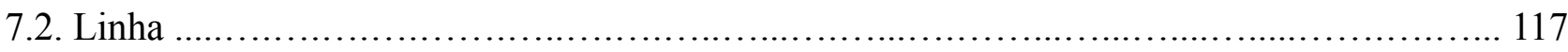

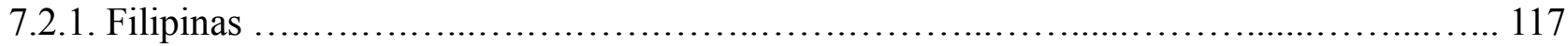

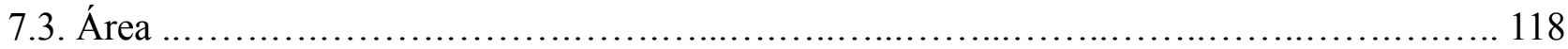

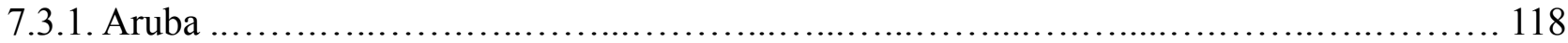

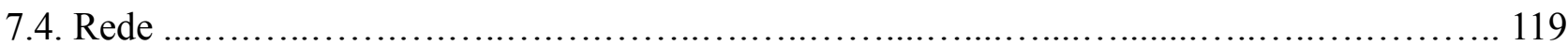

7.4.1. Dependências da Coroa britânica (ilha de Man, ilhas do Canal) ............................. 119

8. Uma síntese das estruturas fundamentais ................................................... 120

CAP. IV. MODELIZAÇÃO GRÁFICA DA ILHA MONTÃO DE TRIGO ....................... 121

A. Caracterização geográfica ............................................................... 121

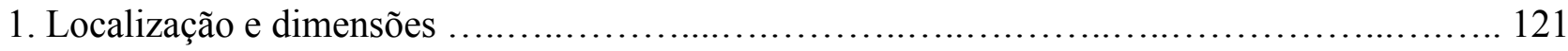

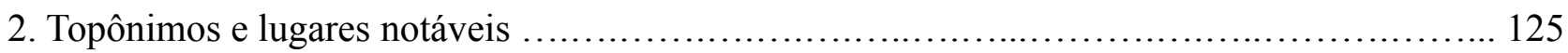

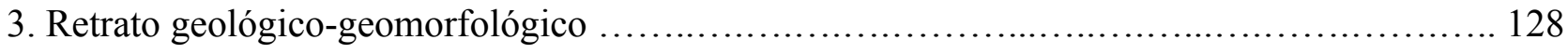

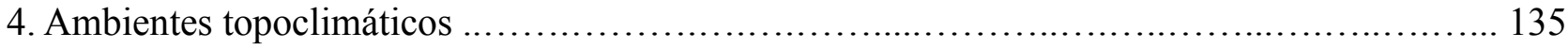

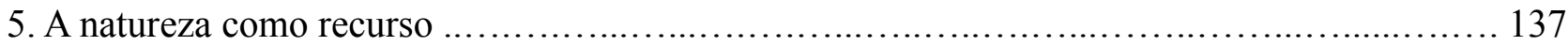

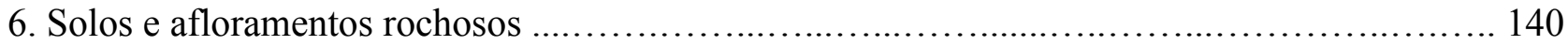

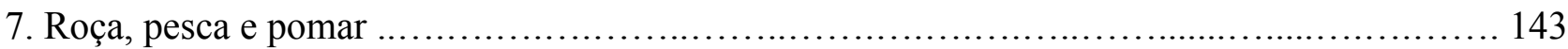

8. Manifestações da floresta ombrófila .................................................... 148

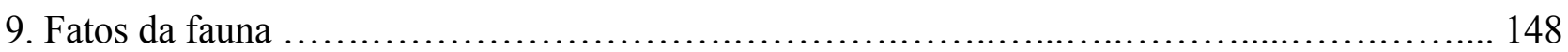

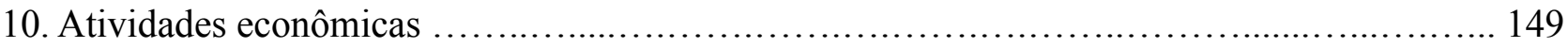

11. Infraestrutura e situação socioeconômica ............................................... 161

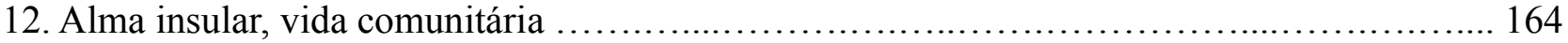

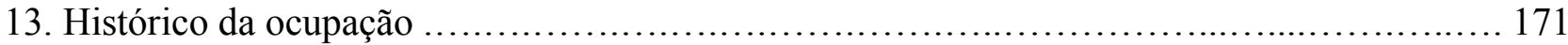

14. Perfil da população ....................................................................... 171

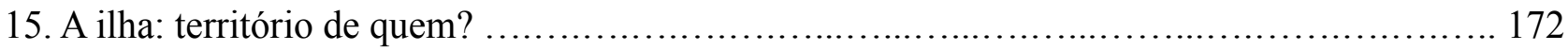

B. Propostas de modelização ............................................................ 173 


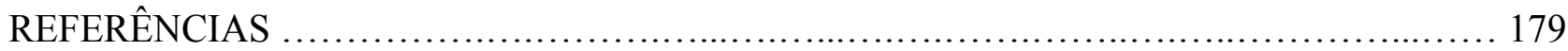

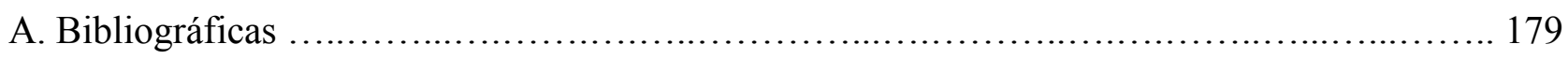

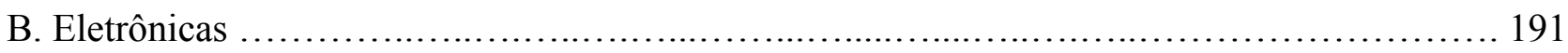




\section{INTRODUÇÃO}

As relações entre a Geografia e a Cartografia são muito antigas. Eratóstenes ${ }^{1}$, um dos primeiros sábios a compor um tratado acerca da ciência geográfica, considerava-a fundamento e explicação do traçado sobre os mapas. Concepção justa por iluminar, para além da conexão entre a arte de representar o ecúmeno e a descrição mestra da Terra, a ligação interna existente entre esses dois saberes e a Geometria - conhecimento, por excelência, das formas e medidas no globo. A despeito das mudanças epistemológicas que sofreram essas disciplinas com o transcorrer dos séculos, há muito o que se conservar de cartográfico na Geografia e de geográfico na Cartografia.

Retirar a medida da Terra é, sem dúvida, passo fundamental para sua descrição rigorosa e, outrossim, para a representação de seu todo ou de uma de suas partes. O espaço existe, de um lado, como medida e qualidade - referenciando o posicionamento e, consequentemente, a distância e a área dos objetos, somos capazes de idealizar relações, possibilidades, magnitudes, influências. De outro, existe como concepção e representação - toda formulação sobre ele é, na verdade, uma forma de concebê-lo, de fazê-lo presente ultrapassando a pura percepção, de re(a)presentá-lo. Representação visual ou mental, quantitativa ou qualitativa, permite um pensar singelo sobre a realidade terrestre.

Elemento de composição da natureza telúrica e de orientação para a vida humana, o mar e as ilhas nele situadas sempre auxiliaram as civilizações para que bem soubessem o lugar que ocupavam num mundo vasto e cheio de mistérios. "É o mar, sobretudo, que descreve e dá forma à Terra"2, configurando toda sorte de articulações, delimitando os continentes, separando e integrando mundos. Referência para a descrição dos territórios ${ }^{3}$, é matéria geográfica por excelência.

\section{A. Cartografia e Geografia Insular}

Objeto deste trabalho, os espaços insulares e as águas que os circundam foram cruciais para a mensuração das terras, para a localização dos povos, para o imaginário das gentes. Fato qualificado e quantificado, percebido e concebido, interpretado e representado, a ilha, como realidade geográfica e dado de consideração cartográfica, tem suas especificidades ora apreciadas, ora questionadas pelos especialistas. São os oceanos ou mares que lhes conferem uma dupla faceta, que, apesar de contraditória, as explica: o isolamento e a possibilidade de comunicação. Da

\footnotetext{
1 ESTRABÃO, 1991a, p. 486

2 Ibidem, p. 505, tradução nossa

3 Idem, 1991b, p. 20
} 
mesma maneira que as águas são estradas para a navegação, seu potencial segregador é fato histórico.

Por meio da Cartografia e derivando concepções da Geometria, a Geografia tem, por desafio, modelar o universo insular, isto é, retirar sua real medida, sua forma, reunir suas essências, suas permanências, seus invariantes. Justamente, por ser matéria contraditória, a essência geográfica das ilhas escapa frequentemente aos especialistas, que, não pouco frequente, negam sua existência ou, de mais a mais, acusam seu estudo de ser um retorno ao determinismo ambiental. Há quem, contudo, afirme categoricamente que, sim, "as ilhas existem, e os insulares, também"4. Isto posto, a tarefa primordial deste trabalho é esmiuçar, por meio da representação gráfica e dos estudos sistemáticos, a especificidade da forma insular.

O ponto inicial desse projeto intelectual é a formulação de que, para cada ilha, como para qualquer localidade do globo terrestre, há sempre uma situação geográfica que a define - a partir da localização relativa a outros elementos da superfície planetária, traça-se sua condição perante o mundo ou uma parte dele. A situação geográfica das ilhas, isto é, sua localização frente aos fatos e objetos do mundo, é concebida a partir da noção de insularidade 5 . Assim, há ilhas que só o são num sentido fisiográfico - o mar é pouco definidor de seus destinos, o isolamento é pouco ou nada marcante. Em outra perspectiva, algumas ilhas não o são de direito, por definição rigorosa, mas, tão submetidas ao jugo das águas (continentais ou marítimas) estão, que não é possível desconsiderar sua condição insular. Existe, destarte, dois sentidos para a ilha: um absoluto (caráter permanente, como pequena porção terral emersa ladeada por água), outro relativo (caráter circunstancial, dada a insularidade a partir de certa posição relativa ou situação) ${ }^{6}$. Com efeito, préstimo em uma ocasião, dano em outra, a insularidade é mercê tanto da natureza insular como de sua localização sobre a Terra.

Para todos os efeitos, deve-se ter em vista que a insularidade é um fato complexo e essencialmente contraditório ${ }^{7}$, visto que está imbuída de aspectos consonantes à transição terramar. Toda transição implica, necessariamente, tensão e complexidade - caso que se pode verificar com facilidade em meios intergrades entre dois domínios morfoclimáticos distintos, em zonas de fronteiras entre países e em áreas de tensão fitoecológica. A contradição é atributo da insularidade por toda a sorte de influências das massas aquáticas na vida biológica e social das ilhas e arquipélagos, que, concomitantemente, separam e conectam. Como estrada, campo de

4 PÉRON, 1993, p. 11, tradução nossa

5 ROYLE, 2001

6 BRUNET et al., 1993

7 RÜE, 1935 
pesca e marca divisória, a água impõe ao gênio humano condições e consequências, constrangimentos e possibilidades.

Os estudos insulares e a representação geográfica das ilhas têm, por temática epistemológica, outras preocupações além das noções de ilha e insularidade, não menos importantes, porém subsidiárias. Em primeiro lugar, não se deve ajuizar a natureza de uma ilha apenas a partir dos fatos da insularidade, sendo necessário observar também as formas de representação simbólica dela decorrentes. Neste ponto, o conceito de ilheidade ${ }^{8}$ tem a capacidade de vincular o universo insular ao imaginário perceptivo e significativo daqueles que o habitam, os ilhéus. Sua expressão evidencia mitos fundadores do espaço vivido, bem como, o que merece maior ênfase, comportamentos induzidos ou construídos a partir da natureza peculiar da ilha. Por conseguinte, se a ilha é resultado de condições de natureza e disposição, emana sua representação da sensação, da percepção e da concepção dadas por tais condições. É justamente atenta a essa ambivalência da realidade insular que se consagra uma representação gráfica útil e rigorosa.

Não menos importantes, irrompem-se os conceitos de maritimidade e de litoralismo, admitidos como a "presença impositiva do oceano" e o "dinamismo costeiro em que a terra e o mar acertam suas diferenças"10, respectivamente. Que a influência exercida pelo mar é elementochave da insularidade, é fato autoevidente. Porém, nem em hipóteses remotas, pode-se fugir ao entendimento de que é característica do universo insular a influência litorânea total, ou seja, de que a vida econômica e social da população tende a ser tão voltada para a costa, como, perigual, as influências da faixa litorânea fazem-se sentir até o interior terral - pelo menos, do ponto de vista climático.

Por fim, vale a pena sublinhar que as ilhas ou arquipélagos também são criações do imaginário. Longe de serem apenas objetos de representação simbólica por parte dos insulares, participam de uma concepção de mundo eminentemente contemporânea, a despeito de suas raízes já arcaicas. A ilha como alteridade é opinião tanto grega como ameríndia, tendo povoado, inclusive, a cosmovisão medieval cristã. Atualmente, advoga o posto de exceção ao mundo globalizado, "último reduto do mundo selvagem"", povoada por seu exotismo característico, por um lado, instigador e apaixonante, e, por outro, ameaçador e umbrático.

Ilhéus ou não, os que amam as ilhas, preferem os lugares pequenos aos grandes, a profundidade à amplitude, o particular ao geral. (...) Em que consiste esse sonho das ilhas? Uma parte dele

8 DIEGUES, 1997, p. 12

9 Ibidem, p. 11

10 SEMPLE, 1941, p. 205, tradução nossa

11 DIEGUES, Op. cit., p. 3 
implica viver em um lugar pequeno. Quanto menor, melhor. Se for muito grande, descaracteriza-se, deixa de parecer uma ilha. O que se procura é um lugar que possa ser percorrido num dia, onde se encontre tudo com facilidade e onde o mar esteja quase sempre à vista. É vital sentir continuamente o mar, pois a sensação de estar cercado por água lembra o quão longe se chegou e o quão afastado se está do resto do mundo (KLUGE, 2008, p. 8-9).

A identidade insular é, portanto, resultado da simbiose entre o ambiente típico das ilhas, com todas as contradições impostas pelo mar, e o imaginário social do ilhéu. Sua gênese existe por oposição a uma externalidade estranha aos traços típicos da maritimidade e da insularidade. Sentimento territorial e ambiental, a ilheidade resulta de contatos históricos, quer porque o insular somente adquire consciência de seu isolamento no instante em que se depara com uma rede comunicativa da qual ele não tem parte, quer porque ele apenas depreende o real significado do ambiente marítimo com o qual comunga quando percebe sua raridade no âmbito de um domínio amplamente terrestre.

Para tratar do fenômeno marítimo e do fato insular com rigor, que seja, de modo a captar o que há de essencial na forma insularidade, a representação gráfica, por dois motivos, pode afirmarse como importante aliada. Primeiro, por ser, ela própria, um modelo, isto é, uma aproximação da realidade - mais útil do que se propor como uma cópia perfeita, é na sua imperfeição que reside sua utilidade. Segundo, por ter um caráter primígeno, nunca acabado, sedento por empiria e aprimoramento. Posto o fato, as imagens deste trabalho serão, antes, focos autônomos de informação do que complementos visuais do texto escrito. Devem possuir a potência de modelar, atribuir a medida das coisas mesmas que re(a)presentam. E se, ao lado da observação empírica, a construção de modelos é tarefa capital da ciência ${ }^{12}$, a modelização gráfica - ou melhor, "a escrita de modelos geográficos sob a forma de figuras"13 - é incumbência utilíssima para a Geografia.

\section{B. Por que Montão de Trigo?}

Pelo mapa da distribuição da população brasileira, nota-se logo os desdobramentos geográficos da função exercida pelos mares durante nossa história. Assim, nesse "país genuinamente atlântico"14, estudar essas massas de água salgada e as ilhas nelas localizadas parecenos imperioso, quer para compreendermos um pouco de nossas origens, quer para tomarmos consciência de nossa situação atual.

12 LÉVI-STRAUSS, 1973, p. 303

13 GRATALOUP, 2003, p. 629

14 AZEVEDO, 1970, p. 17 
No âmbito da realidade insular nacional, o litoral norte do estado de São Paulo distingue-se facilmente, quer pelas dinâmicas atuais de valorização imobiliária que experimenta - com consequente reorganização de seu espaço -, quer pelo rico universo arquipelágico que oferece. Composta por quatro municípios - três majoritariamente continentais (Ubatuba, Caraguatatuba e São Sebastião) e um inteiramente insular (Ilhabela) -, a faixa costeira setentrional paulista possui 41 ilhas, 14 ilhotas e 20 lajes $^{15}$. Por sua vez, uma taxonomia atenta às dinâmicas das aludidas ilhas permite discriminá-las consoante sua ocupação - fixa, temporária e sazonal ${ }^{16}$ - e sua dimensão muito pequenas (de 0,01 a $50 \mathrm{ha}^{17}$ ), pequenas a médias (de 50 a 500 ha) e grandes (mais de 500 ha) ${ }^{18}$.

Na qualidade de laboratório de modelização gráfica, a ilha Montão de Trigo, pertencente ao município de São Sebastião, foi eleita, já porque conta com um duradouro histórico de ocupação fixa, já porque possui uma área média se comparada às demais da região. Situada a pouco mais de $10 \mathrm{Km}$ da Barra do Una, na costa sebastianense, com coordenadas geográficas $23^{\circ} 51^{\prime} \mathrm{S}, 45^{\circ} 47^{\prime} \mathrm{O}$, o terreno monteiro é acentuadamente declivoso, possuindo altitudes que variam de 0 a $289 \mathrm{~m}$, e abriga, na face norte, uma população de aproximadamente 50 habitantes. Sua vegetação florestal tropical pluvial, aliada a campos graminosos e costeira rochosa proeminente, distribui-se pelos 130 ha disponíveis ${ }^{19}$. O conjunto rochoso assemelhado a um vulcão ou a um montículo de trigo, razão do nome característico, tem acesso restrito ao continente, minguada infraestrutura de serviços sociais e intrínseco nexo econômico com o mar.

A predileção pelo espaço dos monteiros deve-se a algumas justificativas principais. Primeiramente, pela insularidade patente, dada pelas parcas possibilidades de acesso de sua população e de sua biota relativamente a outras situações do continente e, mesmo, insulares, conjugada ao seu tamanho razoável, à sua mediana distância à orla continental e à sua singular paisagem de verde conservação, a despeito do uso da terra praticado pelos ilhéus há mais de dois séculos. Secundariamente, pois esse conjunto ideal para o estudo da insularidade brasileira tem sido, no atual momento histórico, objeto de conservação ambiental frente à transformação socioespacial do litoral paulista empreendida pelo turismo e pela especulação imobiliária ${ }^{20}$. Finalmente, por conta da alta emigração e do acentuado desequilíbrio na razão de sexos naquele espaço, que lhe tornam exemplo vivo dos paradigmas da demografia insular.

\footnotetext{
15 PEREIRA et al., 2009, p. 9

16 Ibidem, p. 11

17 Hectares. 1 ha $=1 \mathrm{hm}^{2}=100$ ares $=10.000 \mathrm{~m}^{2}$

18 CONDEPHAAT, 1985 apud FURLAN, 1989, p. 38

19 BARROS, 1997, p. 137

20 FURLAN, 1989, p. 34
} 
Como santuário ecológico e espaço de vida caiçara, Monte de Trigo é caracteristicamente uma realidade invulgar.

\begin{abstract}
O processo de urbanização dos antigos espaços caiçaras é acompanhado por um movimento populacional de várias direções: a mudança espacial da moradia caiçara da beira-mar para os sertões; a migração das populações caiçaras para as cidades e a chegada de migrantes de outras áreas do país (...), primordialmente no ramo da construção civil (CARDOSO, 1996, p. 40).
\end{abstract}

À vista de tal processo, uma pista para a cuidadosa análise da situação insular de Monte de Trigo não parece ser outra senão inquirir-se sobre a presumível permanência de seu estado insular. Até porque o modo de vida ilhéu ou caiçara, típico dos monteiros, não é estranho tampouco externo, na maior parte dos casos, às transformações espaciais supracitadas do litoral norte do estado. Quase via de regra na região e em outras localidades brasileiras, as atividades tradicionais locais (portuária e pesqueira) são mais ou menos abaladas pelo "processo de incorporação das zonas de praia pelas práticas marítimas modernas", que, com o evento do turismo litorâneo, acentuaram a "racionalidade anteriormente empreendida pela vilegiatura" ${ }^{21}$ e pelo desejo de se morar à beira-mar.

\title{
C. Há alguma especificidade geográfica nas ilhas e nos arquipélagos?
}

Que a insularidade é questão digna de cuidado, já é fato discutido, já porque o universo insular possui traços exclusivos (tanto de ordem física como humana), já porque a Geografia Insular é tida como um estudo regional. No que concerne à primeira das justificativas, uma vez caracterizado por suas pequenas dimensões, o espaço insular revela-se aglutinador e rarefeito, pois, se não pode contar com o trunfo de uma heterogeneidade de paisagens - e, tampouco, de manifestações suficientes de um mesmo fenômeno -, resta-lhe traços peculiares em situação de coabitação. Convertendo as energias de dispersão em concentração, a insularidade desenvolve um aguçado senso de unidade territorial ${ }^{22}$. Caso dos povos como da biota, a exiguidade tende a fomentar uma união mais sólida, já que permite a convergência de dinamismos de toda a espécie. Relações entre organismos animais e/ou vegetais podem, por exemplo, derivar de uma simbiose arcaicamente construída no ambiente insular. Ligações comerciais entre ilhéus - de um lado, pescadores, e, de outro, agricultores - também são capazes de fazer transcorrer séculos de convivência mútua. Contudo, se, por uma circunstância especial, elementos estranhos de elevado 
potencial de competição ou de rivalidade são introduzidos numa ilha, a desvantagem dimensional multiplicará rapidamente o conflito. A penetração de um predador exótico, por exemplo, pode ser veloz e devastadora.

Porém, se são elencados todos esses traços típicos para demonstrar a importância do conceito, a insularidade está longe de ser refratária à polêmica. Constatam-se, ao longo de toda a história do pensamento geográfico, dois polos principais de argumentos, o primeiro deles favorável à noção - por considerá-la verdadeiro modelo da realidade geográfica, facilmente compreensível pela diminuta dimensão do espaço insular - e o segundo contrário - cético em relação à capacidade explicativa das dinâmicas do mundo. Desse modo, enquanto se defendia que "por meio de um estudo minucioso e mais cômodo dos pequenos conjuntos, poderemos e deveremos acostumarmonos a determinar as conexões estritamente geográficas entre os fatos naturais e os destinos humanos" 23 , acusava-se que considerar o insularismo como chave de interpretação era, por vezes, um retorno inconsequente ao determinismo, uma vez que a influência da natureza sobre o espírito humano é extremamente oscilante e anacrônica - dá-se mediante períodos de dormência e dominância que se sucedem de modo irregular e episódico ${ }^{24}$.

Diante da controvérsia, pretende-se, com este trabalho, demonstrar em que medida a insularidade é noção digna de atenção por parte dos estudiosos, bem como quais suas formas, isto é, que traços essenciais as explicam, que invariâncias, que conceitos participam de sua definição. Neste último ponto, maritimidade, litoralismo e relação arquipelágica aparecem como alguns dos tópicos que, supõe-se, sejam altamente significativos para se depurar o que há de mais abstrato na substância insular.

Algumas pistas residem nas concepções de exiguidade, raridade, unidade territorial, isolamento e influência aquática, já expostas. Não raro, há quem as tome como ambientes essencialmente frágeis ${ }^{25}$. A fragilidade da biota insular, neste caso, apenas comprova ao homem a persistente vulnerabilidade da natureza do terreno ${ }^{26}$.

Em certa medida, as sociedades insulares podem ser explicadas a partir do espaço que habitam e, na direção oposta, não se deve esquecer que, ele próprio, o espaço, é um produto social. Em outras palavras, a natureza terrestre existe como significado da vida do homem, além de ocupar o posto de condição e resultado de suas ações.

\footnotetext{
23 BRUNHES, 1962, p. 60

24 FEBVRE, 1950, p. 182

25 BROOKFIELD, 1971, p. 57

26 Ibidem, p. 43
} 
O senso comum, a mais trivial das opiniões, percebe a ação humana, drama prescrito ou psicodrama improvisado, como o desenrolar de uma cena já pronta, já adornada.(...) [Porém,] as sociedades não desempenham algo que já está previamente escrito ou decorosamente imposto: elas trabalham, bem como criam e recriam (BRUNET, 2001, p. 18, tradução nossa).

Em companhia dessas meditações sobre a conceituação formal de ilha, de sociedade insular e de insularidade, indaga-se em que tomada pode a representação gráfica protagonizar o debate. Tendo em vista o espaço como um mecanismo capaz de definir os objetos a partir de sua localização, sem embargo, a própria Geografia, como é natural a toda ciência, consiste em mediação da realidade. Não dissemelhante, a ideia de representação, de reapresentação dos fenômenos sob outra roupagem, também é um dispositivo mediador do real, já que retira os fenômenos do caos da percepção imediata para ordená-los conforme uma lógica distinta. Por tal, como a ciência não pode existir sem representar a realidade, o entendimento do espaço só ascende à consciência dos sujeitos à medida que eles o representam, depurando-o daquilo que lhe é acessório e conservando sua substância. O espaço é um mediato objeto de representação na vida do homem ${ }^{27}$. A representação visual captada num só golpe de olhar, denominada gráfica, não é outra coisa que um procedimento exequível para se ter em mente dinâmicas espaciais. É por meio dela, portanto, que este trabalho tentará esboçar o insularismo e a sua miríade de variedades.

Em resumo, o objetivo geral do trabalho consiste em prospectar em que medida a Coremática, por meio da representação gráfica, é capaz de definir a insularidade e descrever os diferentes padrões espaciais presentes em ilhas e arquipélagos. Quanto ao objetivo específico, intenta-se validar os coremas insulares a partir de um exercício prático de modelização gráfica da ilha Montão de Trigo (SP).

No caso da ilha paulista, as concepções medulares que se anseia captar - quando da representação visual gráfica - são, num momento, a insularidade como uma relação dos ilhéus com a ilha que habitam, e, em outro, como um conceito que opõe particularismo interno e mundo externo. Dessa forma, só é caracteristicamente insular um espaço quando apartável de uma matriz geral tendo em vista possíveis barreiras físicas (impostas pelas águas) ou humanas. No caso de Monte de Trigo, a população não só encontra, no mar, seu modo de vida, como sofre com constrangimentos de acesso ao continente. Nesse sentido, duas ponderações amparam esse modo de avaliar a área de estudo. Primeiramente, é válido ter em mente que "a vida social na ilha não se define pelo fato dela estar cercada de água por todos os lados, mas pelas práticas em que estão envolvidos os ilhéus na sua relação com o mar" ${ }^{28}$. Ademais, no caso das ilhas, ressalta-se um jogo

27 BRUNET, 2001, p. 18

28 DIEGUES, Op. cit, p. 31 
intrusivo de contrastes: "o seu isolamento marítimo forma um pano de fundo que põe em evidência a importância das relações que as ligam ao mundo exterior"29.

\section{A investigação da natureza insular}

Para o desenvolvimento deste trabalho, contou-se com uma pesquisa bibliográfica a respeito dos pormenores geográficos da ilha Monte de Trigo, da Geografia Insular, da Coremática e de suas aplicações, da natureza da representação gráfica, das profundas relações entre Geografia e Cartografia, da função da modelização (ou modelagem) na ciência e, por fim, dos clássicos debates - no âmbito da Geografia - em torno da validade conceitual da insularidade. Acerca do espaço insular monteiro, para mais, foram instrumentos de pesquisa alguns sítios eletrônicos de mergulho e turismo, do mesmo modo que reportagens de jornais e revistas. A colaboração de determinados órgãos e instituições, de natureza pública e privada, também foi essencial. Reunidas todas essas fontes de pesquisa (inclusive fotografias, fotografias aéreas e mapeamentos cedidos) e tendo conversado com monteiros e alguns investigadores da ilha, realizaram-se trabalhos de campo em Monte de Trigo entre os dias 11 e 12 de dezembro de 2015 e entre os dias 24 e 26 de julho de 2016 , a fim de verificar hipóteses de pesquisa e validar a cartografia manual realizada até então.

\section{O papel da modelização gráfica}

Os mapas são imagens analógicas da realidade. Exibem-na sob uma perspectiva, dentro de dimensões apropriadas, com medidas e transformações geométricas particulares, de posse de uma linguagem visual plena de intencionalidades. Nunca são a reprodução fiel da realidade, tal qual uma pintura realística, sequer são símbolos isentos das formas reais do terreno. Parecem habitar o domínio da analogia; sugerem suprimindo. "Naturalmente, nenhum mapa pode representar perfeitamente a realidade, mas não fazendo isso, ele é mais útil ainda" 30 . Finalmente, os mapas funcionam como modelos, aproximações seletivas do real.

Apresentado o fato, coabitariam dois tipos de modelização gráfica no âmbito dos estudos geográficos: uma no sentido mais amplo, de seleção visual de elementos do espaço terrestre socialmente apropriado, outra no sentido mais específico, de representação dos próprios conceitos geográficos abstratos na forma de figuras. O primeiro sentido incluiria as imagens analógicas (cartas, mapas, plantas). Já o segundo seria modelo espacial em sentido normativo, forma abstrata 
daquilo que se considera mais significativo tanto num campo de pesquisa próprio (o urbano, o agrário, o insularismo) como num espaço assinalado (o município de São Paulo, a ilha Montão de Trigo). Os mapas são modelos gráficos no primeiro sentido por ainda ocuparem o posto da analogia no que concerne ao espaço representado. Os modelos gráficos no sentido mais restrito, como os trata a Coremática, são pós-cartográficos ou metacartográficos ${ }^{31}$, de outra forma, modelos dos conceitos identificados no espaço representado ao longo de todo o trabalho cartográfico. Vinculado a essa concepção, o modelo nesográfico ${ }^{32}$ funciona como aproximação visual dos conceitos de ilha e de insularidade, percebidos em inúmeros exemplos da Cartografia Insular.

As possibilidades de visualização gráfica e a própria memória visual são imprescindíveis ao trabalho geográfico ${ }^{33}$, seja por permitirem a identificação de prováveis relações espaciais por meio de similitudes de localização que só a vista é capaz de captar, seja por fomentarem a transmissão pedagógica dos conhecimentos sobre o território - para a instrução da população que nele habita e para a ação dos planejadores. Particularmente, imagens sobre as ilhas podem, por vezes, explicá-las mais do que os textos, ofertando chaves de interpretação de sua condição e funcionamento distintivos.

Para que a modelização gráfica dê conta de captar as dinâmicas fundamentais dos espaços insulares, central é, ademais, um inventário geográfico preciso e, concomitantemente, dinâmico que dê conta das especificidades de cada tema sem, com isso, desvinculá-lo de outros aspectos estruturantes. Problema antigo e ainda fundamental da Geografia Regional, associar objetos tanto pela localização como pelos seus atributos sempre foi procedimento áspero. Uma matriz de dados geográficos ${ }^{34}$ é, dessa forma, mais que desejável: com um vetor-coluna oferecendo as características regionais ou locacionais e com um vetor-linha reunindo as características elementares ou substantivas, ficam derivadas a diferenciação das áreas (com comparações do vetor-coluna) e a covariação espacial (por intermédio do elenco organizado do vetor-linha). Uma matriz dinâmica, ou seja, que reagisse às pulsações temporais, tornar-se-ia praticável se intrometidos os tópicos da estabilidade e da instabilidade ${ }^{35}$. Para os que, ainda assim, concebessem a rigidez da matriz como interceptadora de outras possibilidades de análise, há outras propostas - como, a título de exemplo, a que complementa a relatividade de localização no rol de características locacionais e a que transmuta as características elementares em dimensões do espaço geométrico - ordem zero (pontos, localidades); primeira (linhas, redes), segunda (áreas) e terceira ordens (terrenos) ${ }^{36}$.

31 THÉRY, 2004 apud DUTENKEFER, 2010, p. 40

32 Nesografia era o nome anteriormente dado à Geografia Insular.

33 BRUNET, 1962, p. 14

34 BERRY, 1964, p. 6

35 Ibidem, p. 9

36 HAGGETT e CHORLEY, 1975, p. 13 
Na representação coremática de Monte de Trigo, a matriz alternativa de dados geográficos sucederá à clássica. É, pois, na confrontação de ambas que surgirá um retrato regional minucioso.

\section{Dos nexos entre Geografia, Geometria e Cartografia aos corotipos insulares}

Este trabalho possui um percurso lógico de demonstração teórica e de aplicação prática. Em primeiro lugar, aborda-se o espaço como categoria basilar da realidade, com suas correspondências de teorização hipotética (dimensão filosófica do espaço) e de representação formal (dimensão geométrica do espaço). Em segundo, introduz-se o argumento do espaço como matéria de representação, isto é, da representação (inclusive visual) como condição medular para a apreensão do próprio espaço. Em terceiro, demonstra-se, a partir dos princípios da Geografia, que o espaço concreto e o espaço de representação modelam o alicerce da vida humana sobre a Terra. Em quarto, salientam-se os históricos vínculos entre essas duas qualidades do espaço como expressões da ligação indissociável entre a Geografia e a Cartografia. Em quinto, num esforço de harmonizar os dois aspectos do conhecimento científico, a saber, a Nomotética e a Idiográfica, impetra-se a Coremática, gramática da representação geográfica.

Findo o primeiro capítulo, o subsequente adota um caminho diverso para a reflexão. Tratando dos conceitos de insularidade, maritimidade e litoralismo, captar as essências geográficas do universo insular é o objetivo primordial. Para tal, reflete-se sobre o conceito de ilha a partir de múltiplas perspectivas (fisiográfica, geológica, climática, ecológica, locacional, perceptiva, cultural, econômica, social, demográfica, territorial), cada qual atrelada a uma ou a um conjunto de subdivisões da Geografia Geral.

A convergência entre os dois capítulos vem a calhar no terceiro tomo, momento principal da dissertação, quando as concepções de ilha e de insularidade encontram-se com a modelização gráfica sob a luz dos preceitos da Coremática. Para tal, empregamos duas estratégias. Antecedente, mostramos exemplos de modelização gráfica insular, publicados em edições da Revista M@ppemonde ${ }^{37}$. Posteriormente, esboçamos modelos gráficos que retratassem a miríade de possibilidades que as ilhas e arquipélagos assumem na superfície do planeta. Ao cabo, construímos uma tabela com as dinâmicas fundamentais do espaço insular, a exemplo daquela apresentada por Brunet $^{38}$ para os espaços geográficos em geral.

O quarto capítulo funciona tão simplesmente como estudo de caso. Antes de tudo, assumese como a aplicação dos modelos nesográficos - em outros termos, os modelos gráficos que versam

37 Para mais informações, acesse: <http://mappemonde.mgm.fr/>. No periódico, são retratadas realidades regionais do mundo todo mediante uma grande variedade de mapas e outras imagens.

38 BRUNET, 2001, p. 198 
sobre as variedades do universo insular - para um espaço específico, a ilha Montão de Trigo. Dois são os momentos desse último capítulo: um primeiro, de inventário geográfico (localização, relevo, clima, hidrografia, solos, biota, economia, condições e práticas sociais, cultura, política e território, energia, recursos, riscos ambientais, demografia e circulação), e um segundo, de cruzamento de informações segundo a natureza geométrica da variável considerada e sua localização relativa (problemas de linha, ponto e área na alta, na média ou na baixa encosta, citando caso próprio). O resultante desse modo dissemelhante de realizar a caracterização geográfica da ilha permite que, qual intenção da Coremática, o território monteiro possa ser lido como um conjunto vivo de nexos espaciais, como real sistema. Depende, pois, de seu sucesso na exposição imagética de Monte de Trigo a própria validade dos modelos (neso)gráficos propostos.

\section{Modelos gráficos de Montão de Trigo: produtos de um processo}

\subsection{Trabalhos de campo}

As visitas de estudo em Montão de Trigo somente foram praticáveis por intermédio do Pastor Adílson e seu filho, este último barqueiro e morador da ilha, que fez cumprir-se a travessia até ela com tranquilidade e gentileza. Ambos os percursos (de ida e de vinda) duraram, em média, 20 minutos cada e realizaram-se sempre no mesmo dia, ainda que em ocasiões diferentes. Em vista de condições meteorológicas razoáveis (pouca nebulosidade), as intenções de verificação em campo puderam desenrolar-se sem constrangimentos, quer pela mínima interferência dos fenômenos atmosféricos, quer pela quietude marítima ao longo da travessia.

No período matutino, conversamos com representantes da comunidade, que sejam, o Pastor Adilson e sua família, de sobrenome Oliveira, dilucidando questões relativas às condições socioeconômicas dos moradores, às práticas cotidianas, à religião, ao regime de propriedade da terra e aos pontos de referência insular. Em seguida, até o regresso, foram percorridas algumas trilhas a fim de cronometrar tempos médios de andança e alcançar os pontos de verificação in loco dos objetos cartografados. Adiante, é visualizável o mapa de pontos de verificação e caminhos percorridos durante o período de observação da paisagem. Em companhia do mapa, reside uma tabela com as correspondências entre os pontos de verificação e suas coordenadas. A grade de coordenadas cartesianas planorretangulares (próprias do Fuso 23 da Projeção Universal Transversa de Mercator) situada no mapa teve por função a identificação dos pontos em campo. O sistema geodésico horizontal de referência foi o World Geodetic System de 1984 (WGS 84), comum para os receptores do Sistema de Posicionamento Global (GPS). No mapa que 
apresentamos abaixo, note que convertemos as coordenadas referenciadas em WGS 84 para coordenadas referenciadas em SIRGAS 2000 (Datum Geocêntrico para as Américas), atualmente oficial em nosso país.

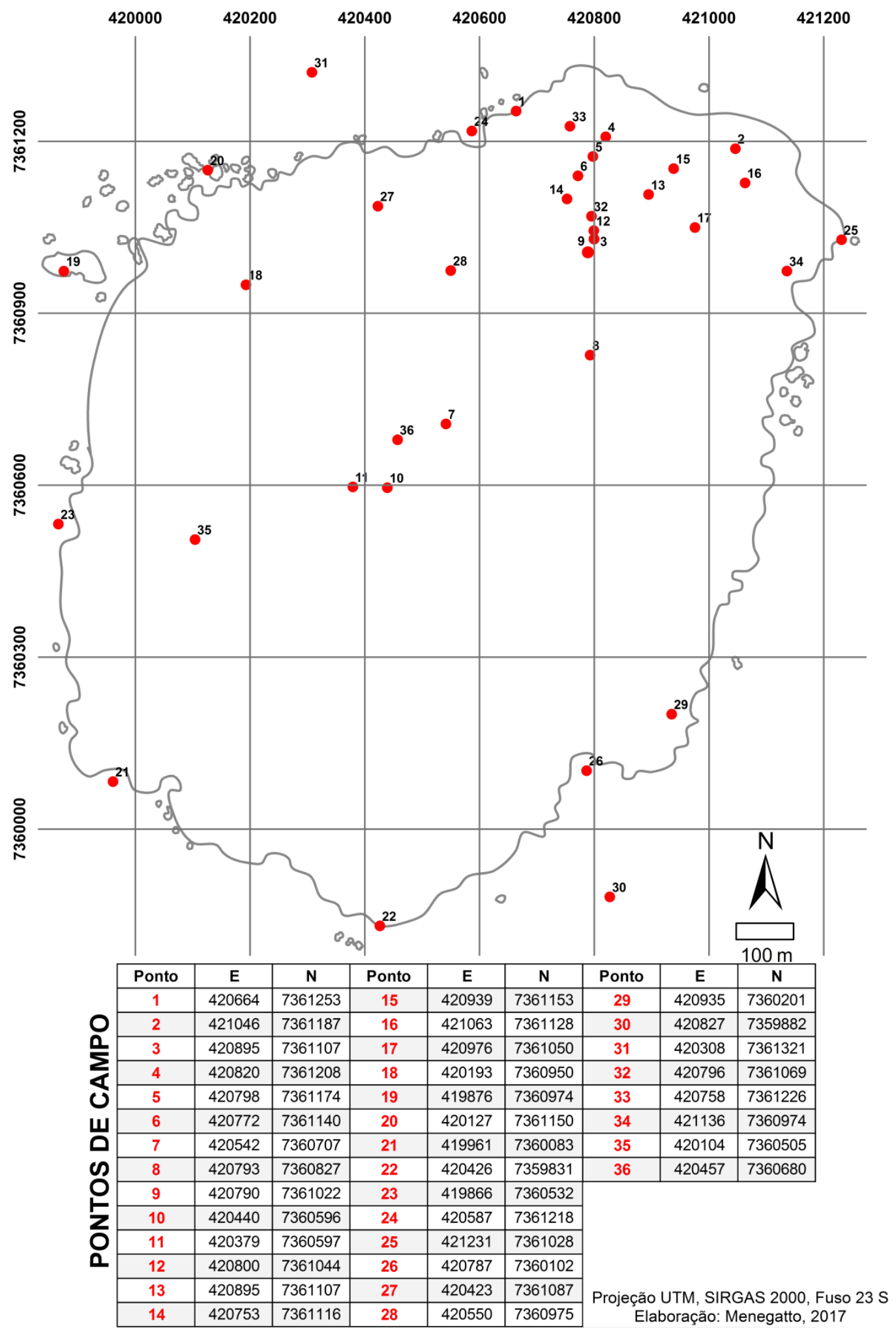

Figura 1. Mapa dos pontos de controle e coleta de dados em campo, na ilha Montão de Trigo, SP 
Em campo, dispôs-se dos seguintes ferramentais: receptor GPS Garmin, relógio com cronômetro, câmera fotográfica, fotografia aérea do Projeto Mapeia São Paulo ${ }^{39}$, Mapa de Pontos Campo, quadro com espaços destinados à anotação dos pontos verificados, telefone móvel, água e alimentos.

\subsection{Mapas}

O processo cartográfico realizou-se de maneira mais ou menos contínua, alicerçando-se em uma sequência rigorosa e em materiais específicos de pesquisa. À revelia de diversas fontes de consulta, cada qual para um único ou um pequeno conjunto de mapas, todos os produtos cartográficos tiveram por base um conjunto de fotografias aéreas digitais (no formato TIFF Tagged Image File Format, não georreferenciado) com área de cobertura da ilha Monte de Trigo e porções haliêuticas adjacentes. Pertencentes ao Sistema Cartográfico Metropolitano (SCM) da Empresa Paulista de Planejamento Metropolitano S.A. (Emplasa), as aerofotos $n^{\circ} 4111620498$, 4111620497, 4111620496, 4111580506, 4111580505 e 4111580504, com resolução espacial de 45 cm, do Projeto de Atualização do Estado de São Paulo - Projeto Mapeia São Paulo (de 2010, 2011), prestaram-se para o processo inicial do mapeamento, qual seja, a restituição estereofotogramétrica, realizada a partir de estereoscópio de bolso. Sem preocupações reais de medida, o procedimento da restituição foi mais frutuoso na identificação de unidades espaciais do que propriamente em sua delimitação com exatidão euclidiana de posicionamento e área.

A etapa subsequente consistiu no cruzamento visual das informações espaciais (manifestas pelas primitivas geométricas de ponto, linha e área) intentando algumas sobreposições dos esboços cartográficos (overlays). O decorrente do trabalho foi, finalmente, um esboço sintético com 36 pontos de apoio a serem verificados em campo, com a ambiguidade posicional própria das fotografias aéreas. Em atenção à orientação de que, "para corrigir a inclinação do eixo, as fotografias aéreas podem ser retificadas com um aparelho que deve restabelecer o quadrado original, ampliando o lado mais curto e reduzindo o outro" ${ }^{40}$, optou-se por solicitar à Emplasa a fotografia aérea ortorretificada da ilha marinha, uma vez que permite efetuar medidas de áreas, distâncias e ângulos ${ }^{41}$. Por sua parte, a ortofotografia apresenta-se em formato digital (TIFF georreferenciado), com resolução espacial de $1 \mathrm{~m}$ e nomenclatura compatível à da escala 1:25.000 do esquema de articulação do Sistema Cartográfico Nacional (SCN), a saber, SF-23-Y-D-V-3-NE.

39 EMPLASA, 2011

40 LIBAULT, 1975, p. 45

41 PANIZZA e FONSECA, 2011, p. 35 
Em seguimento à conferência de campo, o processo de vetorização sobre a ortofoto processou-se de modo a sanar os pontos primaciais de inexatidão. O Sistema de Referência Geocêntrico para as Américas (SIRGAS 2000), o Nível Médio do Mar (NMM) do marégrafo do porto de Imbituba (SC), as coordenadas cartesianas planorretangulares e a Projeção Universal Transversa de Mercator (UTM) representam, na devida ordem, as opções realizadas para os sistemas geodésicos horizontal e vertical, o sistema de coordenadas e a projeção cartográfica. Ademais, a escala de vetorização manual fixou-se em 1:2.500. Os arquivos foram gerados em formato GDB (Geodatabase File), próprios para serem processados no software ArcGIS (versão 10.1), Sistema de Informações Geográficas desenvolvido pelo Environmental Systems Research Institute $(E S R I)^{42}$. Para cada feição criada no interior do banco de dados geográficos, há uma tabela de atributos correspondente. De resto, para construir o perfil topográfico da ilha, apresentado juntamente ao mapa orobatimétrico, empregou-se o módulo ArcScene, interface do mesmo ArcGIS.

Segue-se um quadro com os mapas elaborados, algumas de suas características, as fontes de consulta e, para alguns casos, os métodos e os sistemas taxonômicos usados por base.

42 Para mais informações sobre o instituto ESRI, acessar: <http://www.esri.com/>. 


\begin{tabular}{|c|c|c|c|c|c|}
\hline Nome do mapa & $\begin{array}{c}\text { Modo de } \\
\text { implantação } \\
\text { dos fenômenos }\end{array}$ & $\begin{array}{c}\text { Relação entre os } \\
\text { objetos } \\
\text { representados }\end{array}$ & $\begin{array}{c}\text { Variável (s) } \\
\text { visual (s) } \\
\text { empregada (s) }\end{array}$ & $\begin{array}{l}\text { Fonte (s) de } \\
\text { dados }\end{array}$ & Observação \\
\hline $\begin{array}{l}\text { Abastecimento de } \\
\text { água e energia } \\
\text { elétrica }\end{array}$ & Pontual & Diversidade & Cor & Campo & ---------- \\
\hline $\begin{array}{c}\text { Atividades e } \\
\text { equipamentos sociais } \\
\text { e econômicos }\end{array}$ & Pontual e zonal & Diversidade & Cor e forma & Campo & ---------- \\
\hline Circulação & Pontual e linear & Diversidade & Cor e forma & Campo & $\begin{array}{l}\text { Percorremos as } \\
\text { principais trilhas da } \\
\text { ilha, procurando } \\
\text { sempre medir o } \\
\text { tempo de } \\
\text { deslocamento } \\
\text { utilizando um } \\
\text { relógio com } \\
\text { cronômetro }\end{array}$ \\
\hline Clima & Linear e zonal & $\begin{array}{l}\text { Diversidade e } \\
\text { ordem }\end{array}$ & $\begin{array}{l}\text { Orientação, cor e } \\
\text { valor }\end{array}$ & $\begin{array}{l}\text { Mazzini } \\
\text { (2009); } \\
\text { Sartorello } \\
\text { (2010) }\end{array}$ & $\begin{array}{l}\text { O zoneamento do } \\
\text { mapa é muito mais } \\
\text { esquemático, não } \\
\text { contando, talvez, } \\
\text { com o rigor } \\
\text { necessário para uma } \\
\text { classificação } \\
\text { climática definitiva } \\
\text { para a ilha, quer do } \\
\text { ponto de vista da } \\
\text { localização dos } \\
\text { limites, quer da } \\
\text { perspectiva das } \\
\text { classes taxonômicas }\end{array}$ \\
\hline
\end{tabular}




\begin{tabular}{|c|c|c|c|c|c|}
\hline Litologias & Zonal & Diversidade & Cor e forma & $\begin{array}{l}\text { Enrich } \\
\text { Rojas } \\
(2000)\end{array}$ & $\begin{array}{c}\text { Esse mapa é uma } \\
\text { adaptação do já } \\
\text { elaborado por } \\
\text { Enrich Rojas } \\
\text { (2000). A cor e a } \\
\text { simbologia são as } \\
\text { mesmas por ele } \\
\text { empregadas }\end{array}$ \\
\hline $\begin{array}{l}\text { Localização } \\
\text { geográfica }\end{array}$ & -------- & ---------- & ---------- & --------- & $\begin{array}{l}\text { Não é mapa } \\
\text { temático, e, sim, um } \\
\text { mapa de localização }\end{array}$ \\
\hline Atividade pesqueira & Zonal & Diversidade & $\begin{array}{l}\text { Cor, forma e } \\
\text { orientação }\end{array}$ & $\begin{array}{l}\text { Teramoto } \\
\text { (2014) }\end{array}$ & $\begin{array}{l}\text { Esse mapa é uma } \\
\text { adaptação do já } \\
\text { elaborado por } \\
\text { Teramoto (2014) }\end{array}$ \\
\hline Orobatimetria & Zonal & Ordem & $\begin{array}{c}\text { Cor (em } \\
\text { gradação de } \\
\text { intensidade) e } \\
\text { valor }\end{array}$ & $\begin{array}{c}\text { Coutinho e } \\
\text { Melcher } \\
\text { (1973); } \\
\text { Campo }\end{array}$ & $\begin{array}{c}\text { Trata-se de uma } \\
\text { adaptação do mapa } \\
\text { de Coutinho e } \\
\text { Melcher (1973), } \\
\text { com algumas } \\
\text { modificações } \\
\text { segundo pontos de } \\
\text { controle } \\
\text { adicionados em } \\
\text { campo }\end{array}$ \\
\hline $\begin{array}{l}\text { Planialtimetria de } \\
\text { referência }\end{array}$ & --------- Y Y & --------- & ---------- & $\begin{array}{c}\text { Coutinho e } \\
\text { Melcher } \\
\text { (1973); } \\
\text { Campo }\end{array}$ & $\begin{array}{c}\text { Trata-se de uma } \\
\text { adaptação do mapa } \\
\text { de Coutinho e } \\
\text { Melcher (1973), } \\
\text { com algumas } \\
\text { modificações } \\
\text { segundo pontos de } \\
\text { controle } \\
\text { adicionados em } \\
\text { campo, afora alguns } \\
\text { topônimos } \\
\text { fornecidos por } \\
\text { moradores da ilha. } \\
\text { Não consideramos } \\
\text { um mapa temático, } \\
\text { e, sim, um mapa } \\
\text { básico }\end{array}$ \\
\hline
\end{tabular}




\begin{tabular}{|c|c|c|c|c|c|}
\hline Usos do território & Zonal & Diversidade & Cor & $\begin{array}{l}\text { Carolino } \\
(2010)\end{array}$ & ------ \\
\hline $\begin{array}{l}\text { Unidades fisiográficas } \\
\text { e formas de vertente }\end{array}$ & Zonal & Diversidade & $\begin{array}{l}\text { Cor, forma e } \\
\text { orientação }\end{array}$ & $\begin{array}{c}\text { Coutinho e } \\
\text { Melcher } \\
\text { (1973); } \\
\text { Enrich } \\
\text { Rojas } \\
\text { (2000); } \\
\text { Spinelli } \\
\text { (2007); } \\
\text { Campo }\end{array}$ & $\begin{array}{c}\text { Esse mapa } \\
\text { (também, mais um } \\
\text { esquema que uma } \\
\text { proposição } \\
\text { taxonômica } \\
\text { definitiva) é fruto } \\
\text { de um esforço } \\
\text { intelectual realizado } \\
\text { ao cruzar dados de } \\
\text { altimetria e de } \\
\text { geologia com os } \\
\text { topônimos e as } \\
\text { formas do terreno } \\
\text { citadas pelos } \\
\text { moradores, } \\
\text { constantes em } \\
\text { trabalhos } \\
\text { acadêmicos (coluna } \\
\text { imediatamente à } \\
\text { esquerda) e } \\
\text { observadas em } \\
\text { campo. As cores e } \\
\text { classes taxonômicas } \\
\text { procuraram } \\
\text { obedecer as } \\
\text { recomendações do } \\
\text { Manual Técnico de } \\
\text { Geomorfologia } \\
\text { (IBGE, 2009) }\end{array}$ \\
\hline Solos (um esboço) & Zonal & $\begin{array}{c}\text { A princípio, } \\
\text { diversidade, já } \\
\text { que cada classe é } \\
\text { um tipo de solo } \\
\text { segundo o } \\
\text { Sistema } \\
\text { Brasileiro de } \\
\text { Classificação de } \\
\text { Solos da } \\
\text { Embrapa (IBGE, } \\
\text { 2015). Contudo, } \\
\text { na prática, } \\
\text { observa-se uma } \\
\text { relação de ordem, } \\
\text { dada pela } \\
\text { variação de } \\
\text { intensidade de } \\
\text { brilho das cores. } \\
\text { Essa ordenação, } \\
\text { do mais claro ao } \\
\text { mais escuro, não } \\
\text { obstante, longe de } \\
\text { se constituir um } \\
\text { obstáculo, é, na }\end{array}$ & Cor (e valor) & $\begin{array}{c}\text { Cardoso } \\
\text { (1996); } \\
\text { Enrich } \\
\text { Rojas } \\
\text { (2000); } \\
\text { Sartorello } \\
\text { (2010); } \\
\text { Campo }\end{array}$ & $\begin{array}{l}\text { Esse mapa é, por } \\
\text { excelência, um } \\
\text { esboço, já que é } \\
\text { fruto mais de } \\
\text { inferências segundo } \\
\text { os pontos de campo } \\
\text { e informações } \\
\text { secundárias (coluna } \\
\text { imediatamente à } \\
\text { esquerda) do que } \\
\text { resultado de um } \\
\text { levantamento } \\
\text { pedológico sério. } \\
\text { Não coletamos, } \\
\text { inclusive, quaisquer } \\
\text { amostras de solo. } \\
\text { As cores e as } \\
\text { classes taxonômicas } \\
\text { procuram obedecer } \\
\text { parâmetros do } \\
\text { Manual Técnico de } \\
\text { Pedologia (IBGE, } \\
\text { 2016) }\end{array}$ \\
\hline
\end{tabular}




\begin{tabular}{|c|c|c|c|c|c|}
\hline & & $\begin{array}{c}\text { realidade, } \\
\text { benéfica, pois } \\
\text { coincide com a } \\
\text { direção de } \\
\text { aumento da } \\
\text { proporção de } \\
\text { rochas no solo e } \\
\text { diminuição de } \\
\text { sua profundidade } \\
\text { média }\end{array}$ & & & \\
\hline $\begin{array}{c}\text { Uso e cobertura das } \\
\text { terras }\end{array}$ & Zonal & Diversidade & Cor & Campo & $\begin{array}{c}\text { As cores e classes } \\
\text { taxonômicas } \\
\text { procuram obedecer } \\
\text { parâmetros do } \\
\text { Manual Técnico de } \\
\text { Uso da Terra } \\
\text { (IBGE, 2013) e do } \\
\text { Manual Técnico da } \\
\text { Vegetação } \\
\text { Brasileira (IBGE, } \\
\text { 2012) }\end{array}$ \\
\hline $\begin{array}{c}\text { Uso e cobertura das } \\
\text { terras: vocabulário } \\
\text { caiçara }\end{array}$ & Zonal & Diversidade & Cor & Campo & $\begin{array}{c}\text { Para o nome de } \\
\text { cada classe, } \\
\text { procuramos } \\
\text { reproduzir o } \\
\text { vocabulário dos } \\
\text { próprios monteiros } \\
\text { e aquele constante } \\
\text { no Glossário } \\
\text { Caiçara de Ubatuba } \\
\text { (NÉMETH, 2010) }\end{array}$ \\
\hline
\end{tabular}

Quadro 1. Quadro descritivo dos mapas elaborados

\subsection{Coremas}

Na qualidade de re(a)presentações dos objetos e das dinâmicas que compõem a Terra, com seus símbolos e formas geométricas, os modelos gráficos propõem-se a expor, com a devida perspicuidade, quais estruturas fundamentais (coremas) configuram determinado retrato regional. Acerca de Monte de Trigo, intentou-se construir duas sortes de modelos: um primeiro grupo (modelos analíticos) com imagens de coremas isolados e outro (modelos sintéticos) com estruturas espaciais combinadas. Síntese e análise, nesse caso, percorrem caminhos convergentes - o modelo sintético sugere factíveis interconexões entre os fatos individuais do modelo analítico ${ }^{43}$. 
Como os processos socioterritoriais somente são assimilados à luz das relações entre o tempo histórico e o espaço geográfico, a modelização gráfica da ilha sebastianense ostenta, outrossim, estruturas espaciais pretéritas. Posto que analisar o espaço é mais do que descrever seus elementos numa ordem convencional - mas mostrar sua sucessão e suas interações -, todo espaço possui uma genealogia particular, sendo que, em relação a outros pontos do globo terrestre, há muitas semelhanças e diferenças, explicadas por distintos fatos e momentos que tanto derivaram de traços gerais como resultaram de características específicas ${ }^{44}$.

Tal como na imagem pospositiva, para evidenciar da forma mais nítida - e, portanto, com a menor quantidade de ruídos de comunicação visual - as estruturas e os movimentos do território monteiro, simplificou-se o fundo do mapa da ilha, num sentido próximo ao da esquematização de formas ideais. Ora, dado que "a lógica da modelização e da representação coremática é geométrica e abstrata" ${ }^{45}$, os contornos de costa do espaço insular foram, na sequência, simplificados, depurados e, afinal, geometrizados. 


\section{CAPÍTULO I. UMA GRAMÁTICA PARA REPRESENTAR O ESPAÇO GEOGRÁFICO}

A existência por si mesma, o ser em estado puro, que não acolhe a alteridade, é adimensional - esgota-se como manifestação autorreferente. Não tem referências outras nem pode ser decomponível em partes $^{46}$. É o ponto. Não obstante, a realidade descende da afluência contraditória e cooperada entre a identidade e a diferença, o ser e o não-ser. O espaço, manifestação particular dessa afluência - a identidade como coincidência e a diferença como dispersão - é capital substância do real. O ponto, por si, não admite a realidade tal como ela é, exceto se abandonado o prisma autocentrado, se admitido um conjunto de pontos. Nesse caso, a ótica adimensional e, em decorrência, não espacial, transmuta-se em dimensional e, portanto, espacial, já que comporta o lugar (ponto em si) e a distância (outros pontos que não o primeiro).

A realidade dimensional ou espacial aceita, em princípio, três dimensões: a linha (derivação de um conjunto de pontos, "comprimento sem largura" ${ }^{47}$ ), a área (proveniência do desvio de duas linhas, "largura mais comprimento" ${ }^{48}$ ) e o volume (distanciamento possível entre áreas ou planos, produto da área com a altura). Também qualificado de geométrico, o espaço dimensional é expressão sensível das próprias formas, do invariante dos seres, de sua essência exordial.

\section{A. Espaço geométrico, espaço geográfico}

Forma é constância substancial. A viabilidade da realidade decorre tanto da permanência do ser (da presença de formas) como da sua correspondência com um mundo perceptivo de corrupção (da aderência de um conteúdo a uma forma). A forma espacial é, antes, qualidade abstrata essencial a todo objeto. Por conseguinte, dessa forma, decorrem noções subjacentes às manifestações todas da realidade. São os princípios comuns, "proposições imediatas à demonstração"49, justamente imediatas por não serem antecedidas por nenhuma outra.

São noções comuns ${ }^{50}$ que "as coisas iguais que coincidem entre si são iguais entre si" e que "o todo é maior que a parte" ${ }^{51}$. Os objetos dispõem-se no mundo segundo esses princípios: é por não ocuparem rigorosamente o mesmo espaço que são desiguais e é por assentarem-se numa dimensão do espaço (primeira ou reta, segunda ou plano e terceira ou volume) que se vinculam uns aos outros. O espaço geométrico tridimensional é, por esse motivo, uma totalidade, e suas

46 EUCLIDES, 1991, p. 189

47 Ibidem, p. 189

48 Ibidem, p. 191

49 ARISTÓTELES, 1991, p. 217

50 As noções comuns de Euclides (1991) assemelhar-se-iam aos princípios comuns de Aristóteles (1991).

51 EUCLIDES, Op. cit., p. 201, tradução nossa 
partes representam as dimensões imediatamente inferiores. Nele, é exequível a mensuração do volume (tridimensionalidade), da área (bidimensionalidade), da distância (monodimensionalidade) e da localização (definição geométrica primitiva).

Contudo, salienta-se, as dimensões que, em simbiose, estruturam o espaço geométrico não têm por exórdio tão somente as relações de volume, área e distância. Aliás, pensar dimensão como categoria de relação parece ser menos restritivo e apropriado. Desse modo, volume, área e distância são apenas categorias de relação possíveis para o espaço, nunca exclusivas, já que também é lícito avaliá-lo unicamente pelas possibilidades de ligação (espaço-rede).

Mesmo no caso de um espaço que priorize as relações de volume, área e distância, há mais de um modo de fazê-lo. Na hipótese de se acatar o espaço como o resultante do desvio entre planos $^{52}$, as medidas feitas sobre uma superfície esférica, elipsoidal (caso da Terra) ou hiperbólica não teriam validade. Para mais, há quem considere o tempo como a quarta dimensão do espaço ${ }^{53}$, já porque, no desenrolar das ações, ínterim e instante associam-se, respectivamente, a desvio e coincidência, já porque o espaçamento entre objetos implica inevitavelmente a duração para percorrê-lo. No espaço-tempo, concepção do espaço físico oriunda de uma ótica particular de espaço geométrico, ponto implica tanto uma localização no espaço como um instante do tempo, e a distância entre os pontos é, na realidade, uma sucessão - surgem, daí, o acontecimento (simbiose localização-instante) e o intervalo (mutualismo distância-duração) ${ }^{54}$.

Tido como a representação do espaço que conserva determinada propriedade para todo um conjunto de pontos ${ }^{55}$, o espaço geométrico pode ser dividido em duas categorias prevalecentes: é topológico se regido por relações de conectividade, e é projetivo se comandado por correspondências formais de volume, área e/ou distância. De seu partido, a natureza projetiva assume-se euclidiana, desde que esteja alicerçada em simetrias e equivalências de planos em desvio, e não-euclidiana, caso se baseie em superfícies outras que não o plano (geometrias elíptica e hiperbólica, a título de exemplo) $)^{56}$.

52 Espaço definido por intermédio dos postulados de Euclides (Op. cit., p. 197-198, tradução nossa), quais sejam: "1. Traçar uma reta de um ponto qualquer até outro ponto qualquer. 2. Prolongar continuamente uma reta finita em linha reta. 3. Descrever um círculo com qualquer centro e distância. 4. Todos os ângulos retos são iguais entre si. 5. Se uma reta cruzar duas retas numa situação em que os ângulos internos do mesmo lado forem menores que dois retos, as duas retas, quando prolongadas indefinidamente, encontrar-se-ão no lado em que estão os ângulos menores que dois retos". Este último, o Postulado das Paralelas, foi motivo de controvérsia ao longo da história do pensamento geométrico, e sua refutação inaugurou as possibilidades de um pensamento pós-euclidiano, de outras geometrias praticáveis. São proposições análogas a esse postulado: a soma dos ângulos de um triângulo é igual à de dois retos; retas paralelas são equidistantes e guardam, entre si, uma distância finita; retas não equidistantes divergem em uma direção e convergem em outra; em um quadrilátero com três ângulos retos, o quarto também é reto; com três pontos não alinhados, é sempre possível construir um círculo que passe por todos eles.

53 HARVEY, 1973, p. 215

54 ARGENTIÈRE, 1958, p. 43

55 HARVEY, Op. cit., p. 203

56 Ibidem, p. 205 
O movimento universal, o desencadear dos acontecimentos, manifesta-se por intermédio do espaço físico, qualidade dos objetos concretos. É necessário, todavia, indicar que, se são concretos os objetos, sua qualidade espacial é, antes, abstrata. Acessá-la no plano formal, da forma pura, é investigar suas propriedades, é embrenhar-se nos domínios do espaço geométrico. Antes de procederem-se possíveis acusações, uma ressalva: o espaço não é anterior aos objetos - existe a partir deles sem com eles se confundir. A qualidade espacial, apesar de abstrata, não está apartada do mundo concreto, pois dele participa na condição de forma, de invariante. Caso se discorresse em sentido contrário, o efeito não seria outro senão uma duplicação desnecessária da realidade.

A localização é, por princípio, a preambular categoria do espaço. Todas as outras dimensões (quer num sentido projetivo euclidiano ou não-euclidiano, quer num sentido topológico) apenas granjeiam sentido se dela emanarem. A localização designa a determinação espacial de um objeto, que seja, a definição de seus prováveis desvios e coincidências. Um ponto no espaço é, em si, uma localização, dada ou a partir de um sistema externo de referências (localização absoluta), ou comparativamente a outros pontos (localização relativa) ${ }^{57}$. Com frequência, o espaço físico explica a localização dos fenômenos por meio de um sistema de referência de propriedades geométricas conhecidas. Caso do espaço-tempo da física relativística, a geometria não-euclidiana foi escora providencial $^{58}$.

Se o espaço está dado como categoria medular da realidade, como forma básica da existência, é com os objetos que ele se manifesta e pode ser sentido, percebido e concebido. Mediação fundamental entre os fatos do mundo, ele não é "o ambiente (lógico e real) onde as coisas se dispõem", mas "a potência universal de suas conexões"59. Toda localização, outrossim, mesmo que referenciada num sistema externo de coordenadas, mesmo que balizada num espaço geométrico, existe em relação a alguma coisa - é por não se bastarem que os objetos possuem uma qualidade eminentemente espacial. O espaço de relações representa o espaço físico por excelência.

Quando são os homens a matéria-prima de um espaço de relação, isto é, quando suas localizações são definidas pelas próprias dinâmicas que lhes dizem respeito, defronta-se com o espaço social. Isso porque as relações sociais afluem como relações espaciais. Expressão do fato, o público e o privado, duas dimensões da vida humana, representam, na devida ordem, o externo e o interno, duas dimensões do espaço orgânico. É do próprio trato social vínculos próximos e distantes de certo indivíduo, oscilações de intimidade mensuráveis na forma de distâncias afetivas. Não raro, os espaços de um escritório são compartimentados conforme a posição 
hierárquica dos trabalhadores. Naturalmente, as nuances do espírito humano, tanto no nível individual como no comunitário, ensejam inconstâncias difíceis de serem explicadas por uma propriedade espacial comum. O espaço social é anisotrópico e anisocrônico - fato não invulgar no próprio espaço físico -, de modo que sua relação com o espaço geométrico (onde todos os pontos gozam de uma mesma propriedade) está longe de ser de todo compatível ou harmônica. E, está claro, tal ressalva estende-se ao espaço dito geográfico, já que aqui o entendemos tanto como o espaço físico terrestre socialmente apropriado quanto como o espaço social teluricamente manifesto.

Por último, das íntimas relações entre a Geografia e a Geometria, efluem, por espírito e ação de derivação, três notáveis conceitos para os estudos geográficos sistemáticos. Ora, quando da proposição $n^{\circ} 35$ da geometria euclidiana, de que "os paralelogramos que estão sobre a mesma base e entre as mesmas paralelas são iguais entre si" ${ }^{60}$, é de todo desejável pormenorizar as definições de congruência geométrica (igualdade de forma), equivalência geométrica (igualdade de área) e coincidência geométrica (superposição), donde descendem as noções de congruência geográfica (igualdade de fenômenos), equivalência geográfica (igualdade de magnitude) e coincidência geográfica (igualdade de lugar).

\section{B. Cartografia e espaço de representação}

$\mathrm{Na}$ qualidade de linguagem, de sistema de signos, o mapa assenta-se no domínio das imagens. Discurso de uma ausência, a imagem medeia a relação entre o sujeito e o objeto, o homem e o mundo. É sistema de signos não-verbais e não-sequenciais de representação de um objeto ou de um conjunto de objetos, concreto ou abstrato, material ou mental ${ }^{61}$.

Posto o signo como tudo o que é tomado no lugar de algo, que o remete de alguma forma, sua gênese provém da vinculação entre significante (imagem sensorial) e significado (conceito) ${ }^{62}$. $\mathrm{O}$ conceito é dado por uma forma, um invariante. De seu partido, o signo é sua alusão na sua condição própria de ausência - e o significante é o meio sensorial pelo qual se é capaz, sob um estímulo, de realizar tal alusão. Neste caso, a acepção de imagem ata-se à ideia de referência ou insinuação. A palavra, por exemplo, é um signo linguístico cujos sons (imagem sonora) ou a combinação de caracteres num livro (estímulo visual que se converte em imagem sonora) reportam para um

60 EUCLIDES, Op. cit., p. 245-246, tradução nossa

61 LUSSAULT, 2003, p. 485

62 SAUSSURE, 1975 , p. 80 
conceito - a imagem sonora e o conceito participam, em respectivo, como significante e significado. No caso da imagem visual, o que mais compete ao trabalho, o desenho subsiste como signo que une o traçado visualmente captável (significante) a uma noção particular (significado). Sendo a comunicação a interação entre sujeitos com o intento de transmitir entendimentos ou ideias sobre a realidade, é a linguagem, isto é, o sistema de signos comuns, o instrumento indispensável para realizá-la e, isto posto, produzir mensagens (ideias ou entendimentos compartilhados). A imagem visual, com todos os desenhos, ícones, símbolos e figuras que é capaz de oferecer, constitui-se um sistema de signos (uma linguagem) que, por não dispor de ordem de leitura, não necessita de conexão com as palavras. Daí, "a linguagem visual está ligada a um sistema atemporal e espacial (não sequencial), diferente da linguagem verbal, ligada a um sistema temporal e linear (sequencial). O resultado é a visão imediata e total de uma imagem no nível global, de percepção imediata"63.

Há diversas possibilidades para a imagem. Se figurativa, é polissêmica, que seja, oportuniza uma miríade de interpretações, posto que imita o real, ele próprio objeto da percepção subjetiva. Ao contrário, uma imagem analógica, que referencie as formas da realidade sem reproduzi-las, que as re(a)presente sem imitá-las - como é o caso dos mapas - deve almejar a monossemia (isto é, um caminho interpretativo uníssono) se intentar contemplar um público multímodo. Ademais, a linguagem visual, para vir a ser um todo significativo ou um polo de discurso autônomo com vantagens sobre outras linguagens, necessita retratar objetos e fenômenos de modo a fazê-los perceptíveis num só golpe de olhar. É a essa qualidade distinta da imagem que se atribui o adjetivo gráfica. Desse modo, uma imagem gráfica permanece exposta como uma "forma de conjunto captada num instante mínimo de percepção", tendo a seu dispor um "sistema semiológico monossêmico" $"$.

Os mapas devem formar imagens, ou melhor, têm de funcionar como imagens gráficas dispondo de uma forma de apresentação monossêmica e legível. Por sua vez, a legibilidade de um mapa depende do contraste ou da gradação que a distribuição espacial de dados é capaz de oferecer. Uma configuração espacial estruturada por uma série de atributos depende tanto de uma memória como de uma habilidade espaciais do leitor somente praticáveis quando as formas são simples e legíveis ${ }^{65}$.

Afora sugestões de legibilidade cartográfica, é indispensável atentar-se para os propósitos do mapa. Como veículo de comunicação do espaço, todo mapa demanda indicar, com clareza, um ou todos os princípios da análise geográfica, a saber, a extensão, a coordenação e a causalidade dos 63 FONSECA, 2004, p. 161 
fenômenos ${ }^{66}$. Para tal, é indispensável que, de um lado, o leitor seja capaz de identificar quais fatos são comuns a determinado lugar (“em tal lugar, o que há?”), e, de outro, possa visualizar, com relativa facilidade a distribuição de um fato definido (“tal caráter, qual sua geografia?”) ${ }^{67}$. A sério, a Semiologia Gráfica emana dum esforço de captar os mecanismos sensitivo-cognitivos do ser humano concernentes à linguagem gráfica e tem por tarefa primordial evitar os equívocos de linguagem de muitos dos produtos da Cartografia.

$\mathrm{Na}$ linguagem visual, três são as relações entre os objetos: ordem, diversidade e proporcionalidade. Também três são os modos de implantação gráfica: pontual, linear e zonal. Afinal, seis são as modulações visuais sensíveis, a partir das quais se é exequível demonstrar, na forma de imagem e na posse de um dos modos de implantação, uma ou mais relações entre os objetos. Para relações de diversidade, ressaltam-se a granulação, a cor, a orientação e a forma (variáveis visuais de separação). No caso da quantidade e da ordem, conta-se com, em respectivo, o tamanho e a intensidade (valores dentro de uma mesma cor ou cores em gradação). Afora as seis variáveis, não se deve esquecer das duas dimensões do plano (o comprimento e a largura), que, conjuntas, compõem um espaço de representação onde qualquer outra modulação visual, de acordo com seu propósito, poderia aderir ${ }^{68}$. Em outros termos, cria-se a imagem visual "modulando as duas dimensões do plano $(\mathrm{X}, \mathrm{Y})(\ldots)$ e variando visualmente manchas em terceira dimensão visual $(Z)$ que atraem a atenção do leitor, cada uma delas inscrita em dada posição do referido plano"

Lado a lado com a cronologia (seriação histórica), a corologia (distribuição geográfica) é "uma das duas bases constantes e universais de comparação que o homem dispõe, já que permite registrar qualquer caráter e torná-lo, assim, comparável a qualquer outro" ${ }^{~} 70$. Com efeito, "considerada isoladamente, a Cartografia, mesmo influenciada pela Semiologia Gráfica, não chega a ser geográfica enquanto for apenas um inventário de objetos numa porção de espaço"71. Por conseguinte, parece ser útil à Geografia a Cartografia que possibilite uma ágil apreensão da distribuição espacial dos fenômenos e, doravante, uma cuidadosa análise de sua extensão, coordenação ou causalidade. Isso porque "o mapa não é um fim em si mesmo; visa proporcionar um meio para atingir um objetivo prático e científico"72.

66 DE MARTONNE, 1913, p. 21-22

67 BERTIN, 1988, p. 47

68 JOLY, 1990, p. 4

69 MARTINELLI, Op. cit., p. 9

70 BERTIN, Op. cit., p. 45

71 FONSECA, Op. cit, p. 16

72 GUERRA, 1993, p. 77 


\section{Forma, estrutura, configuração, sistema}

O triângulo é forma elementar. Ele pode ser isósceles, escaleno ou equilátero; acutângulo, retângulo ou obtusângulo; parâmetro de medida para o geômetra, ferramenta para o engenheiro, instrumento para o músico, símbolo para o místico, técnica para o agrimensor; grande ou pequeno; presente na mobília ou na casa. Porém, isso tudo não é a forma do triângulo. Todas essas coisas são, antes, manifestações do triângulo, mas nunca o triângulo em si, pois, como forma, ele é propriedade, qualidade única. É precisamente no invariante dessas manifestações que se pode captar o triângulo em si, sua forma abstrata - a todo momento corrompida pela realidade concreta, que lhe imita sem cessar. A valer, o que há em comum entre dois navios marrons, cinco lápis marrons, vinte caules de árvore marrons é o fato de serem, como óbvio, marrons. Não obstante, não é o marrom específico daquele caule ou dos aludidos navios que permanece, e sim o marrom por si mesmo, o marrom como qualidade, forma persistente à adulteração dos objetos.

A par da forma como um invariante ${ }^{73}$, a forma espacial está dada pela vinculação contraditória e simbiótica entre coincidência e distância. Por si mesma, contudo, a forma não é objeto de compreensão. Se ela o é, deve-se, antes, à manifestação dos próprios objetos, cuja existência não-espacial é rigorosamente impossível. Todo objeto, para existir, ocupa um espaço - e isso faz do espaço caráter essencial. Como o espaço geográfico ocupa o eixo central da reflexão, são suas qualidades de espaçamento e gravitação que mais devem chamar a atenção. Na superfície terrestre, não há, pois, um só elemento ou um só fenômeno que ocorra sem atrair ou se distanciar-se de outro. Com efeito, a forma espacial (numa acepção geográfica) fulgura nas cidades (polos de influência e, em consequência, centros de gravidade), nos oceanos (ou barreiras aparentemente intransponíveis, ou canais de circulação), nos maciços florestais (refúgios da civilização), nos centros comerciais (pontos de conexão com o mundo globalizado).

"Como a Terra é uma, também o é a humanidade"74. Não falta razão aos que assim pensam. Decerto, não só os fenômenos de um lugar sofrem com a intervenção de outra porção do globo, como as analogias são inúmeras. Obstinadamente, a fisionomia de uma região é uma agremiação particular de episódios e componentes do espaço físico-social terrestre. Isso significa que a descrição de cada região conduz sempre a aspectos gerais de interpretação do mundo, já que a relação causal entre os fenômenos que nela ocorrem não só pode ser observada em outros lugares, como, muitas vezes, provém de princípios espaciais mais ou menos generalizados. Quando se declara ser a Geografia "uma ciência descritiva" - revelação etimológica que é - já se tem de

73 PLATÃO, 1999, p. 115-190

74 SEMPLE, Op. cit., p. 31, tradução nossa 
abarcar os princípios comuns que geram critérios taxonômicos de caracterização. Porquanto, "toda boa descrição presume o exato conhecimento do objeto que deve ser descrito e, ao mesmo tempo, dos objetos afins mais ou menos próximos, com os quais esse tem muitas características em comum" "75. Por tradição, é a Geografia uma ciência ideográfica. Por necessidade hodierna, também é nomotética. E, portanto, se a Geografia Regional é "o estudo sintético de uma porção do espaço terrestre"76, incerto é seu destino sem a Geografia Geral, que, por sua vez, guarnece os estudos descritivos de preceitos compartilhados.

À vista disso, é impraticável pensar o espaço sem as relações comuns que o definem e que, combinadas em regiões, geram quadros geográficos característicos. Com efeito, cinco $^{77}$ são os modos de interação existentes entre o espaço social e o espaço físico terrestre: o habitar ("habituarse a estar no lugar" ${ }^{98}$ ), o apropriar (controlar, destinar e repartir o território ${ }^{79}$ ), o explorar (beneficiar-se das aptidões dos ambientes e produzir vantagens comparativas pela especialização do trabalho ${ }^{80}$ ), o circular (integrar-se e, assim, relativizar as distâncias ${ }^{81}$ ) e o gerir ou reger (traçar o caminho a seguir a partir de ordem, organização e ideias comuns ${ }^{82}$ ). Essas dinâmicas fundamentais do espaço social manifestam-se na superfície terrestre sob cinco formas correspondentes - hábitat (habitar), malha (apropriar), divisão espacial do trabalho (explorar), rede (circular) e lugar central (gerir ou reger) - e, pelo menos, mais quatro derivadas da combinação entre dinâmicas - rede de lugares (habitar e circular), produção fundiária e imobiliária (habitar e apropriar), produção (apropriar e explorar) e circulação de bens (circular e explorar) ${ }^{83}$.

Se é tarefa da Geografia estudar os processos e as formas que o espaço é capaz de assumir ${ }^{84}$ e se as dinâmicas fundamentais do espaço social teluricamente manifesto constituem esses tais processos e formas, admite-se cada uma dessas dinâmicas como uma estrutura social, que seja, como uma forma possível de associação entre o espaço social teluricamente manifesto e o espaço físico terrestre socialmente apropriado. Ora, a estrutura não passa de um arranjo. Pois bem, estrutura é arranjo de partes, é unidade de relação. Forma é invariância atributiva, permanência de qualidades. Quando uma estrutura conta com um modelo para explicá-la, disso resulta uma forma. E, se "as relações sociais são a matéria-prima empregada para a construção dos modelos que

75 RATZEL, 1990, p. 94

76 BRUNET, 1962, p. 12

77 Ibidem, p. 11

78 Ibidem, p. 21

79 Ibidem, p. 22, 24

80 Ibidem, p. 26

81 Ibidem, p. 29

82 Ibidem, p. 30

83 Ibidem, p. 21

84 Ibidem, p. 11 
tornam manifesta a própria estrutura social" ${ }^{15}$, não devem ser outras senão as relações espaciais o alicerce dos modelos que expõem a estrutura espacial. A título de exemplo, uma estrutura fundiária resulta de relações de apropriação e habitação entre os homens e a Terra (sendo a posse privada o anverso organizacional e a malha de glebas o obverso material da estrutura), e é por intermédio de um modelo explicativo (de uma demonstração de aspectos essenciais dessas relações) que se está apto a tomar por forma a apropriação privada da terra.

A estrutura deriva da interação entre atores do espaço (indivíduo, família, comunidade, coletividade local, empresa, Estado, organização supranacional ${ }^{86}$ ), ou mesmo, entre lugares, decompondo-se numa série de categorias, tais quais material, de configurações, de fluxos e de ligações. Ela introduz os elementos de ordem topológica, exprimindo determinada situação ou conjunto de lógicas espaciais ("espaçamento, distância, gravitação"87), a par de também traduzir intenções e estratégias de atores sociais (resultantes da prática social) e configurar a natureza topográfica da relação entre o homem e o meio físico.

Com efeito, o corema (do radical grego chor, "extensão") é a estrutura elementar do espaço $^{88}$. É a unidade básica que, exibindo-se sob inúmeras roupagens, pode, lançando mão de regras de composição, constituir o retrato de um espaço, tal qual, se o exemplo for a Linguística, o papel desempenhado pelos radicais na formação das palavras, pelas preposições na construção de sentido das frases e pelas conjunções na organização das orações. E, "se a estrutura nos dá a medida mesma ou a expressão das relações sociais" ${ }^{\text {"9 }}$, fundando-se como uma forma tornada cognoscível por intermédio dum modelo, o corema é a chave de interpretação das relações espaciais manifesta por modelos de representação gráfica (modelos gráficos). Ele representa desde estruturas materiais (ou mesmo, visíveis) de objetos arranjados (terrenos, construções, equipamentos) até estruturas de configurações, fluxos e organizações ${ }^{90}$.

Dada a estrutura como o componente fundamental do espaço, é ele, o espaço, uma estrutura, já porque compõe outro espaço de maior dimensão, já porque evidencia um princípio relacional: a anisotropia. A desigualdade de localização e de dimensão num espaço não engendra outra coisa senão uma distribuição - e toda distribuição é disposição particular, estrutura espacial. Por conseguinte, como as distribuições significam precisamente que o espaço é estruturado e como

\footnotetext{
85 LÉVI-STRAUSS, 1962, p. 316

86 BRUNET, 2001, p. 34

87 Ibidem, p. 156

88 Ibidem, p. 195

89 Ibidem, p. 156

90 Ibidem, loc. cit.
} 
a estrutura de um espaço é conjunto organizado de estruturas, rigorosamente, “o espaço é estrutura de estruturas"91.

Em sua qualidade abstrata, as estruturas podem afigurar-se como formas individualizadas, muito embora, na realidade concreta, elas existam senão na relação umas com as outras, seja para expor a situação dos objetos num determinado contexto (conjunto de estruturas como configuração), seja para denotar uma relação fisiológica, de funcionamento do mundo (conjunto de estruturas como sistema). Se a configuração é propensa a modificar-se segundo as situações, a configuração especificamente espacial é a morfologia engendrada pela permanência das posições relativas dos objetos em dado espaço ${ }^{92}$, visto que são as ligações e os distanciamentos que precisam a localização de cada um dos objetos, daí descendendo relações como hierarquia, interdependência e competição. E, se um sistema é um conjunto de partes organizadas e com reciprocidade de influência, um sistema espacial é uma agremiação dos objetos cuja mudança de uma localização afeta, direta ou indiretamente, todas as demais. Outrossim, como todo sistema contém atores e ações com variados graus de autonomia, cada um reúne espontaneamente toda uma sorte de subsistemas ${ }^{93}$. Estrutura das estruturas, o espaço é configuração de localizações e sistema de sistemas.

\section{Modelos e modelização gráfica}

O modelo é "uma estruturação simplificada da realidade que supostamente apresenta, de forma generalizada, características ou relações importantes" "94. Ele seleciona ("pela eliminação de detalhes acidentes, permite salientar alguns aspectos fundamentais, importantes ou interessantes do mundo real sob alguma forma generalizada"95), estrutura (já que a Ciência anseia padrões e conexões) e reaplica-se (por suprimir contingências, pode, com frequência, conservar características partilhadas por muitos objetos ou fenômenos, donde sua facilidade de ser duplicado ou estendido). Não pretendendo ser uma cópia fiel da realidade, o modelo busca captar o que há de essencial em determinado fenômeno, correspondendo mais a um produto abstrato do raciocínio intelectual do que a uma reprodução idêntica do mundo tal qual ele se nos apresenta. Daí sua importância. Com o propósito de manifestar a forma do fenômeno, seu invariante ou essência, ele o (re)apresenta - sob

\footnotetext{
91 Ibidem, p. 158

92 Ibidem, p. 200

93 Ibidem, p. 63

94 HAGGETT e CHORLEY, Op. cit. p. 3

95 Ibidem, p. 4
} 
outro aspecto, de modo a sublinhar uma ou algumas de suas propriedades -, e nisto consiste sua capacidade de demonstração, de persuasiva.

O mapa é um modelo. Sendo uma (re)apresentação dos fenômenos sob os ângulos da localização e, consequentemente, da distribuição captável pela vista (a supracitada representação gráfica), ele é seletivo, estruturado e extensível. Destarte, tinha razão quem admitiu serem os mapas "modelos icônicos, ou representativos e conceituais", já por traduzirem "tentativas estruturadas oriundas do ensejo do ser humano em comunicar aos seus semelhantes algo da natureza do mundo real"96. E não menos lúcido se é em asseverar que, "reconhecendo os mapas como modelos do mundo real e empregando-os como modelos conceituais, a fim de compreendê-los melhor, está garantida sua importância central na metodologia geográfica" ${ }^{97}$. Em meio ao caos da realidade imediata, tornar cognoscível as relações espaciais que a animam pela mediação do mapa é mais do que desejável. Os vínculos antigos entre a Geografia e a Cartografia provêm da própria conduta científica, que acessa o imediato por recurso do mediato. Ora, e o que é a representação senão uma mediação?

Não obstante, é mister delimitar a extensão do mapa no âmbito do universo dos modelos, pois, como já suficientemente demonstrado, o poder do mapa sobre a leitura do mundo consiste precisamente em seu potencial analógico. Ele referencia espaços específicos lançando mão de uma linguagem monossêmica e visualmente significativa. Mais descritiva do que normativa, a modelização cartográfica é uma etapa fundamental para captar invariâncias e constituir, assim, modelos análogos que representem circunstâncias geográficas comuns a dois ou mais espaços. Doravante, na qualidade de figuras geográficas, despertam os modelos pós-cartográficos como meios de demonstração de princípios espaciais sob uma ótica lógica e taxonômica. Ferramentais da eloquência geográfica, tais figuras podem representar malhas e divisões, redes (visíveis e invisíveis), grades, marcas pretéritas do território, auréolas de gradientes a partir de um ponto, bandeamentos advindos de uma linha, polarizações urbanas, anisotropias, formações e reformulações espaciais, rupturas, interfaces, frentes de expansão e de retração, barreiras e descontinuidades ${ }^{98}$. 


\section{E. Coremática: um vínculo entre as vertentes nomotética e idiográfica da Geografia}

Como a língua humana, o espaço é estrutura das estruturas. Se, na linguagem verbal, há unidades sonoras mínimas (fonemas) que, combinadas, engendram monemas, isto é, unidades mínimas de articulação entre um significante e um significado - sejam com valor gramatical (morfemas), sejam com valor semântico (lexemas) ${ }^{99}$-, da reunião de coremas, de matizadas naturezas, dimana o espaço. O corema representa, da mesma maneira, "a menor unidade de valor distinto que permite descrever a linguagem gráfica em torno das estruturas elementares" ${ }^{100}$. Para gozar de sucesso, a língua deve pretender-se instrumento de comunicação, de interação entre indivíduos com capacidade de transmissão de pensamentos. E, a despeito das circunstâncias em que a polissemia ostenta beleza poética, o mau uso da língua (barbarismos, solecismos, cacofonias, ambiguidades, preciosismos e toda profusão de equívocos comunicativos e vícios de linguagem) não só pode acarretar confusão e constrangimento, como, não raro, propicia interpretações distorcidas da realidade, donde vem a tão necessária norma linguística, a Gramática.

A par de uma Gramática que garanta a boa comunicação entre os indivíduos, há a Coremática, salvaguarda da boa construção e composição dos coremas na forma de modelos gráficos. Contanto que a estrutura seja uma forma abstrata cuja manifestação fenomênica procede de sua aderência a um modelo, a uma esquematização daquilo que é real, o corema é a estrutura espacial traduzida pelo modelo gráfico. Com a Coremática, a modelização gráfica descortina-se como possibilidade de leitura acurada das principais relações espaciais e de seus tropismos. Ferramenta de bom exame geográfico, a Coremática, no âmbito do GIP-RECLUS (Grupo de Interesse Público francês intitulado Réseau d'Etude des Changements dans les Localisations et les Unités Spatiales), por exemplo, foi de grande valia para a avaliação prospectiva e para o planejamento dos territórios ${ }^{101}$.

Presumivelmente, na qualidade de retórica demonstrativa, a modelização gráfica a partir da Coremática está sempre vinculada a algumas das mais precípuas concepções. Assim, vale recordar, no contexto dos fatos geográficos, sua relação basal (entre o espaço social teluricamente manifesto e o espaço terrestre socialmente apropriado), seus atributos fundamentais (semelhança e distância), seus motores elementares (espaçamento e gravidade), seus princípios primevos (de distribuição, coordenação e causalidade espaciais) e, mais pertinentes, seus conceitos indispensáveis (congruência, equivalência e coincidência). Como o modelo é o próprio objetivo da

99 LÉVI-STRAUSS, 1962, p. 242

100 DOSSE, 1993, p. 359

101 GONÇALVES, 2012, p. 15 
análise estrutural $^{102}$, a interpretação coremática deve valer-se de figuras geométricas apropriadas para recuperar dinâmicas geográficas. De mais a mais, se o ponto expressa lugar (aglomerado, centro, localidade), a linha sinaliza separação (divisa, limite, frente, fronteira, interface) ou união (intersecção), a área denota superfície (parcela, território, unidade político-administrativa, cinturão, região, zona, campo, mancha), o círculo representa gravitação (auréolas, órbitas) e o triângulo assinala relação tripartite (rede) ${ }^{103}$, basta cruzar esses traços representativos com as dinâmicas espaciais fundamentais para obter os coremas de base de todo modelo gráfico. Precisamente, um conjunto de 28 coremas fundamentais ("expressão cartográfica das estruturas e das dinâmicas geográficas") advém do entroncamento entre "as principais ações da sociedade no espaço geográfico" (malha, disposição, gravitação, contato, tropismo, dinâmica territorial e hierarquia) e os "elementos de base donde se dispõe de toda a representação icônica" ${ }^{104}$ (ponto, linha, área e rede).

Finalmente, as propriedades de igualdade de espécie (congruência geográfica), de magnitude (equivalência geográfica) e de lugar (coincidência geográfica) re(a)presentam-se, na justa ordem, na forma de mesma simbologia, mesmo tamanho e mesma localização. A título de exemplo, uma área de irrigação e uma rede de circulação têm em comum o fato de representarem a forma espacial "disposição" (orientação e ligação), mas, enquanto, em uma, o modo de implantação é zonal, em outra, ele é linear. Caso se superponham em considerável gama de pontos, compartilham de uma coincidência geográfica e podem estar próximas de uma equivalência geográfica, porém é somente sob certo aspecto que comungam de congruência geográfica.

102 LÉVI-STRAUSS, 1962, p. 316

103 BRUNET, 2001, p. 199

104 Ibidem, p. 198, tradução nossa 


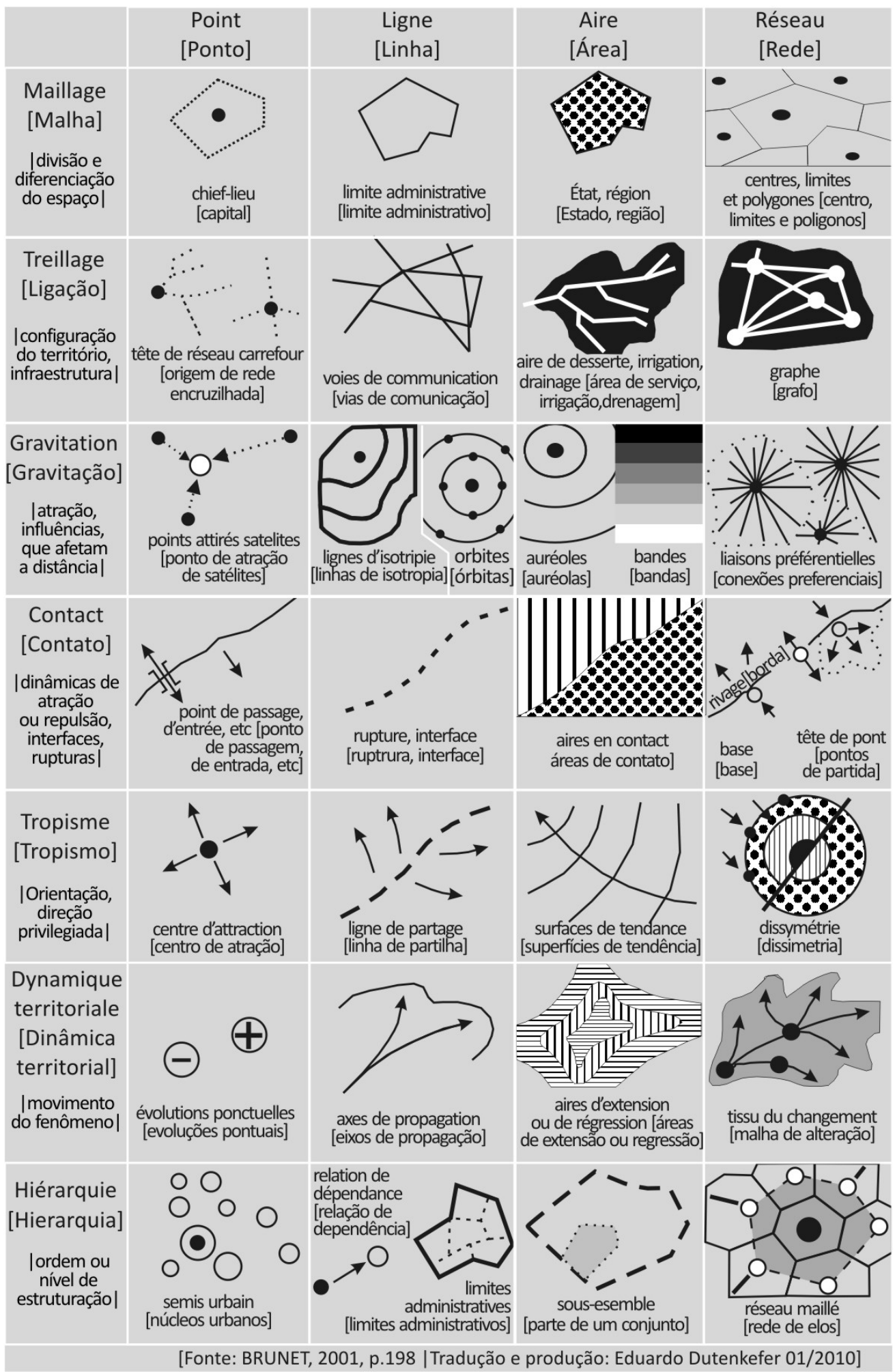

Quadro 2. Coremas propostos por Brunet (2001, p. 198). Tradução e produção: Dutenkefer (2010) 
Da relação entre o espaço social teluricamente manifesto e o espaço físico terrestre socialmente apropriado, há os fisiomorfemas ${ }^{105}$, dados da natureza da superfície planetária, rugosidades aptas a sinalizar dissimetrias, limites territoriais, padrões de ocupação do terreno e unidades regionais, podendo potencializar ou diminuir relações sociais, "aproximar ou distanciar" ${ }^{\prime 106}$. De seu partido, também as estruturas e dinâmicas naturais são representáveis por elementos geométricos fundamentais: por ilustração, o ponto é acidente específico (lago, dolina, vulcão, pico, protuberância) ou foco de fenômeno (recurso mineral, inundação, sismo, epidemia, poluição/contaminação); a linha sinaliza limite bioclimático, faixa de dobramento (cadeia, cordilheira), falha ou fratura, escarpa, monoclinal, rio, fundo de vale ou interflúvio; e, afinal, a área circunscreve extensão de estruturas geológicas (plataforma, maciço, bacia), zonas climáticas e ecossistemas ${ }^{107}$.

E da relação entre o espaço e o tempo, irrompem-se os cronocoremas ou coremas datados (que evidenciam um conjunto de espacialidades de uma área em dado momento ou indicam os processos de mudança que alteram as estruturas sociais vigentes) e os paleocoremas ("vestígios atuais, nas estruturas presentes, de fenômenos passados"108).

Retomando, as estruturas elementares ou coremas funcionam como signos, e o sistema de signos imagéticos que permite representar a realidade geográfica em suas diversas nuances é o que se chama linguagem gráfica. Ora, se esses signos representarem cada qual uma estrutura elementar do espaço, ter-se-á um exercício de modelização gráfica. Precisamente, da qualidade esquemática e conceitual dos modelos gráficos depende a correta leitura do território. Concernente à dimensão conceitual, bem vale a recomendação de que "para merecer o nome de estrutura, os modelos devem, exclusivamente, satisfazer a quatro condições"109: 1. Oferecer um caráter de sistema (uma modificação num elemento acarreta modificações em todo o conjunto); 2. Pertencer a uma classe de transformações (grupos ou famílias de modelos, de acordo com a natureza da dinâmica); 3. Prever a reação dos modelos à modificação da estrutura; 4. Explicar, a partir de seu funcionamento, todos os fatos observados. Atinente à expressão gráfica, o modelo, na qualidade de croqui, de expressão imagética demonstrativa porque pedagógica, deve ser "claro e legível" (donde se deriva que é necessário abordá-lo com clareza de conjunto), “esquemático" (somente algumas informações quer sejam do fundo do mapa, quer sejam relativas a detalhes temáticos - são eleitas como merecedoras de representação), "rigoroso" ("deve resumir sem depreciar", visto que "a exatidão da

\footnotetext{
105 Ibidem, p. 202

106 Ibidem, p. 203

107 Ibidem, p. 200-201

108 THÉRY, 2005, p. 171

109 LÉVI-STRAUSS, 1962, p. 316
} 
análise é condição indispensável da síntese") e "evocativo" (expressivo que é, demanda relevo à imagem, restituindo multifários planos da paisagem) ${ }^{110}$.

Que a forma é um invariante, já está claro. Daí a alegação de que “compreender o sentido de um termo é permutá-lo em todos os seus contextos" ${ }^{111}$. Com efeito, os coremas representam, por meio dos modelos gráficos, formas geográficas comuns a dois ou mais espaços - sem, é evidente, rejeitar o que é peculiar a cada lugar. Precisamente, frente à já anosa dicotomia entre a descrição e a normatização, problemática que se anunciou tão logo nasceu a Geografia moderna, a Coremática irrompe como novidade não só no tratamento gráfico como na interpretação teórico-conceitual do mundo. Isso porque "o corema é o elo fundamental há muito em falta na teoria geográfica entre o espaço geral e os espaços específicos, desatando a clássica contradição entre a nomotética e a idiográfica, a ciência do espaço e o conhecimento dos lugares particulares" ${ }^{\prime 12}$.

Para mais, o supracitado princípio geográfico da coordenação recupera que, no globo terráqueo, fenômenos similares tendem a possuir localizações similares, ao passo que fenômenos localizados no mesmo espaço, ao menos algum vínculo mantêm entre si. Posto que, sob uma miríade de perspectivas, algumas condições geográficas replicam-se em diferentes lugares, desponta a concepção de coremas-tipo, corotipos. Propriamente, se o "corema é uma estrutura elementar, de extensão universal ou, ao menos, geral", o "corotipo é uma forma complexa

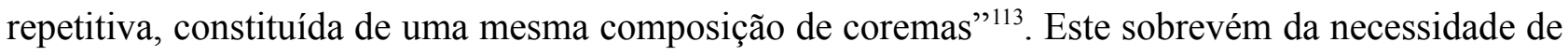
retratar contextos geográficos similares (áreas de piemonte em diferentes continentes, manchas de agricultura monocultora de exportação - plantations - em países de variados níveis de pujança econômica), seja em modelos gráficos com estruturas combinadas (modelos sintéticos), seja com estruturas elementares (modelos analíticos).

Do parecer de que "qualquer espaço é a combinação de estruturas elementares - os coremas - representadas por modelos gráficos" ${ }^{\text {"114 }}$, toda uma sorte de estudos acadêmicos já deste século procuram retratar, de maneira sintética e esquemática, geografias de lugares particulares. Dentre alguns exemplos, são de enorme valia, dado o préstimo com que foram elaborados e a capacidade evocativa que encerram, os trabalhos de Panizza ${ }^{115}$, Théry ${ }^{116}$, Gonçalves ${ }^{117}$, Poncet ${ }^{118}$,

\footnotetext{
110 BRUNET, 1962, p.18-26

111 LÉVI-STRAUSS, 1973, p. 141

112 BRUNET, 2001, p. 196, tradução nossa

113 Ibidem, p. 217, tradução nossa

114 DUTENKEFER, Op. cit., p. 106

115 PANIZZA, 2008

116 THÉRY, 2004

117 GONÇALVES, 2012

118 PONCET, 2004
} 
Dutenkefer $^{119}$, Cognard $^{120}$ e Girardi ${ }^{121}$, que, em respectivo, retratam, via modelização gráfica e segundo mais ou menos preceitos coremáticos, as dinâmicas do litoral potiguar, a heterogeneidade das regiões brasileiras, a avaliação prospectiva e o planejamento territorial da capital paulista, as especificidades do continente australiano, os elementos fundamentais da Região Metropolitana de São Paulo, a formação socioterritorial neozelandesa e a questão agrária nacional. 


\section{CAPÍTULO II. LITORALISMO, MARITIMIDADE E INSULARIDADE}

A Geografia Insular, isto é, o estudo geográfico das ilhas e arquipélagos, atravessa o pensamento humano desde a Grécia Antiga, granjeando novas roupagens com a passagem dos séculos, seja nas tradicionais escolas determinista e possibilista, seja no pensamento ecológico ou nos estudos de mundialização, típicos da virada do século.

De certa forma, a importância dos estudos insulares advém da autoridade científica que possuem as análises dos ambientes costeiros, já que, estes, com sua dinâmica terra-mar, estão presentes não só nos continentes, como também ajudam a definir a própria realidade insular - que não se esqueça da vinculação lógica entre os conceitos de insularismo e litoralismo. A costa é "a linha que limita o mar onde este parece invadir a terra, porém, inversamente, também é a linha de frente da própria terra onde esta parece invadir o mar" ${ }^{122}$. Isso porque o tropismo das zonas litorâneas parece usufruir de uma dupla direção: do mesmo modo que o mar intervém na terra (climática e economicamente, por exemplo), a terra usufrui das condições impostas pelo mar para poder espraiar-se (o que se justifica tanto pelas navegações como pela exploração econômica das águas e leito oceânicos). Sendo a ilha um espaço litoral característico, não há melhor laboratório para investigar essa dinâmica de interfaces.

Mesmo diante de uma postura cada vez mais ativa (frente a uma passividade pretérita à natureza terráquea), os destinos humanos obedecem a três fatores geográficos cuja importância já é fato histórico: a distância (um obstáculo a vencer, mais do que nunca, mensurado em termos de tempo), a diferença de nível (ação deixada à gravidade para exercer-se sobre as águas) e, ele mesmo, o espaço (a superfície não só ocupada, como também ocupável) ${ }^{123}$. Especificamente, dado que esses três aspectos nela exibem feições próprias, é a ilha singularidade digna de nota: a aparente inexorabilidade da distância imposta pelo mar, a despeito de sua marcante atuação tanto num sentido social como do ponto de vista biológico, é matéria de polêmica numa aldeia global; a protuberância paisagística de cada ilha denota, como diferença de nível que é, uma contingência terrestre numa matriz aquática (seja marítima, no caso das ilhas oceânicas, seja fluvial ou lacustre, quando em corpos d'água continentais); a exiguidade de espaço disponível pode ser ou constrangimento sem par (limitação ao povoamento ou à exploração econômica), ou motivo, dado o adensamento populacional que se é capaz de ensejar, para conquistas além-mar.

122 FEBVRE, Op. cit., 214

123 BRUNHES, Op. cit., 447 


\section{A. $O$ conceito de ilha}

A ilha é uma porção relativamente pequena de terras emersas circundadas por água doce ou salgada. A diferença em relação a um continente está na extensão: os continentes manifestam-se de modo mais significativo à vista de quem olha para o conjunto das terras firmes do globo. Convencionalmente, com 7,5 milhões de $\mathrm{km}^{2}$, é a Austrália o menor dos continentes, e, com pouco mais de 2 milhões de $\mathrm{km}^{2}$, é a Groenlândia a maior das ilhas ${ }^{124}$, donde se extrai que toda terra emersa contínua com dimensão superior à australiana será um continente, ao passo que, será uma ilha aquela de dimensão inferior aos quilômetros quadrados groenlandeses. Com efeito, essa definição, salvo sua antiguidade, não é apenas produto de convenção da comunidade científica, mas também matéria de apreciação lógica. Uma boa justificativa está justamente na influência marítima: enquanto, no ambiente continental, o influxo marítimo - tanto climático (maritimidade), como econômico (exploração dos recursos haliêuticos) e social (modo de vida costeiro) - restringe-se senão à baixada litorânea ou a algumas raras concavidades fisiográficas que permitem uma penetração um pouco mais intensa (estuários, deltas, baías), no ambiente insular, ele está por toda parte, sendo episódica qualquer desvinculação absoluta com o litoral ou com o próprio mar. A ilha é, assim, mais do que pura e simplesmente a miniatura de um continente.

De seu lado, o arquipélago particulariza-se como um conjunto de ilhas - frequentemente, de mesma gênese geológica e/ou geomorfológica ${ }^{125}$-, bem como de "águas circunjacentes e outros elementos naturais que estejam tão estritamente relacionados entre si" de modo a constituírem "uma entidade geográfica, econômica ou política ou que historicamente tenham sido consideradas como tal" 126 .

\section{B. Perspectivas fisiográfica e genética}

Em termos fisiográficos ou geomorfológicos, uma ilha caracteriza-se como um alteamento do modelado terrestre que, por destacar-se como terra emersa no íntimo de uma ambiência aquática, permanece como um permanente convite à vista. Como destaque na paisagem, a ilha constitui o típico local onde os processos costeiros habitualmente ocupam o primeiro plano - fato que se deve à sua pequena extensão. No caso do continente, outros processos interiores (erosão eólica, formação de rede hídrica complexa, sedimentação em grandes bacias), coexistindo lado a lado, roubam a cena.

124 CIA. The World Factbook. Verbetes consultados: Australia; Greenland. 
São duas as classes de ilha: as continentais ou costeiras (de natureza similar à continental, já porque se exibem como simples continuação do continente, já porque se estabelecem na própria margem continental) e as oceânicas ou isoladas (de gênese independente). Atinente ao grupo de formas costeiras, as ilhas categorizam-se em de erosão, de sedimentação, de afundamento, de afundamento e erosão combinados e residuais, podendo desdobrar-se em fluviais (do Bananal), marinhas (do Cardoso, Comprida) e fluviomarinhas (de Marajó). Aí prevalecem as ilhas brasileiras: São Luís, Itamaracá, do Governador, Grande, de Santa Catarina, dentre outros tantos exemplos. Já as ilhas oceânicas, ou são vulcânicas, ou são biogênicas (recifes coralígenos), sendo, nesta qualidade, poucos os exemplos em território nacional: arquipélagos de Trindade e Martim Vaz e de Fernando de Noronha, penedos de São Paulo e São Pedro e atol das Rocas ${ }^{127}$. As ilhas costeiras do país surgiram em seguida a inúmeras regressões e transgressões marinhas, sobretudo do Quaternário, segregando-se do continente sem, com ele, deixar de conservar semelhanças ${ }^{128}$.

Também há quem catalogue as ilhas no quesito genético. Identificam-se, assim, as de limites de placas tectônicas - sejam divergentes (Islândia, Trindade), sejam convergentes (Antilhas, Sandwich do Sul), sejam transcorrentes (Cikobia e Clipperton, no Pacífico) -, as intraplacas - ora de lineamentos (Havaí, Marquesas), ora de aglomerados (Canárias, Cabo Verde), ora isoladas $(\text { Santa Helena })^{129}$. Neste caso intraplacas, as fraturas no substrato oceânico engendram obras da arquitetura natural de singular beleza. Tanto no arquipélago havaiano como no cabo-verdiano, identificam-se aquilo que os geólogos denominam hot spot (ponto quente), área da crosta terrestre conectada a plumas térmicas (ascendência magmática subcrustal). Justamente, em ambos os arquipélagos, a crosta delgada permitiu que o magma, além de espraiar-se horizontalmente em zona subterrânea, estivesse presente na forma de atividade vulcânica ${ }^{130}$. De mais a mais, quando vulcânicas, não raro, as ilhas são reféns de deslocamentos tectônicos - nos espaços insulares com característica movimentação de terras, são comuns inversões de base e de topo ${ }^{131}$.

Outra forma de tectonismo associado, o arco insular abunda em zonas de subducção, nas quais as ilhas podem apresentar terrenos sedimentares altamente dobrados. Trata-se de uma linha curva contemplada por uma miríade de ilhas cujos primórdios se congregam à atividade vulcânica e à ascensão do assoalho oceânico. Tanto no lado exterior do arco como na linha a ele paralela, uma fossa oceânica é frequentemente encontrada, o que, aliás, é típico do Pacífico ocidental (Honshu, Marianas) ${ }^{132}$.

127 GUERRA, Op. cit., p. 234

128 FURLAN, 1989, p. 29

129 NUNN, 1994 apud WHITTAKER e FERNÁNDEZ-PALACIOS, 2008, p. 19

130 WITHERICK et. al, 2001, p. 125

131 DE MARTONNE, Op. cit., p. 715-716

132 WITHERICK et. al, Op. cit., p. 140 
No respeitante às ilhas sedimentares, quer de ordem biogênica, quer de ordem química ou física, dois casos particulares merecem realce: o atol e a ilha barreira. No primeiro caso, comum no Pacífico, o que se tem é um recife coralígeno circundante a uma laguna central. Sua origem associase a antigas ilhas (vulcânicas ou sedimentares) que sofreram submersão (por erosão, subsidência do assoalho oceânico, ou mesmo, variações do nível médio dos mares) e, na atualidade, servem de plataforma para o crescimento dos corais. Exemplificado pelo atol das Rocas, o colapso da porção mais interna do recife orgânico conduz à formação de um anel capaz de isolar, parcial ou totalmente, uma área lagunar ${ }^{133}$. Já no segundo caso, observa-se uma ilha arenosa baixa paralela à costa e desta apartada por uma laguna. De seu lado, seu processo formativo desenlaça-se mediante uma transgressão marinha sucedida pela emergência de uma barra submersa (a transgressão forma uma superfície arenosa baixa submetida à ação construtiva das ondas, enquanto o crescimento da barra arenosa advém de deposição eólica ou de erosão costeira ${ }^{134}$. Para além desses dois casos e, nem por isso, pouco comum, verifica-se o tômbolo, uma união entre ilha e continente ensejada por uma barra de acúmulo sedimentar ${ }^{135}$.

Já dito, litoralismo e insularidade confundem-se: na ilha, o que lhe é, aliás, característico, a diferenciação litoral-interior é questão difícil ${ }^{136}$. Tanto as formas quanto os processos são tipicamente costeiros ou, pelo menos, possuem, direta ou indiretamente, alguma influência litorânea. Há, mesmo, ilhas onde essa diferenciação carece de qualquer significância, dada a mesma gênese e o mesmo nível altimétrico entre área interna e área costeira.

A todos esses fatos, acrescenta-se que, de uma gênese ou de outra (vulcânica ou sedimentar, continental ou oceânica), com um ou outro modelado distintivo (plano, colinoso, montanhoso), cada ilha está contemplada com determinada variedade costeira, que, por sua vez, pode revelar algumas particularidades do regime morfológico nela existente. Os tipos mais comuns são: as planícies costeiras (geralmente formadas em condições de relativa estabilidade tectônica, com possível presença de cordões arenosos), costas de lagunas (ambientes salobros por detrás das barras ou cordões arenosos, frequentemente alimentados pela água do mar durante a maré cheia), costas de estuário (reunião entre erosão fluvial e avanço do mar pelos canais, com suas águas mixoalinas, constituem verdadeiros berçários biológicos), costas de deltas (planícies aluviais desenvolvem-se nas próprias desembocaduras fluviais, com presença de ilhas diversas, dado o aumento da carga sedimentar pela redução da capacidade erosiva), costas de enseada (avanço do mar perpendicularmente aos dobramentos do relevo, erosão destacada nas ilhas e recifes), costas de rias

133 Ibidem, p. 14

134 Ibidem, p. 17

135 Ibidem, p. 267

136 RATZEL, Op. cit., p. 169 
e rivieras (em maciços antigos, de granitos ou de outras rochas cristalinas, morros e picos são reduzidos ao estado de peneplanície e sofrem um novo ciclo erosivo na forma de vales estreitos e encaixados numa plataforma uniforme, com depressões alongadas e golfos estreitos), costas de colapso e atividade vulcânica (praias, ilhas, golfos em formato de barra, podendo aparecer sob aspecto primitivo, quando de um visível colapso semicircular com edificações de cones vulcânicos, ou sob aspecto atenuado, quando de uma sedimentação fornecida pelos aportes eruptivos) e costas glaciais (presença de fiordes, definidos como esculturas rochosas da última glaciação preenchidas por água e com aspecto recortado $)^{137}$.

O tipo de costa promove, ao lado da proximidade, uma maior ou menor facilidade de povoamento, bem como um maior ou menor vínculo com as ilhas próximas. Pois, já na época de $\operatorname{Ritter}^{138}$, era lecionado que a presença de articulações costeiras favoreceria o povoamento por atenuar os constrangimentos da ação oceânica e, por conseguinte, levar mais longe os efeitos dessa ação rumo ao interior terral.

\section{Perspectiva climática}

Do ponto de vista climático, as ilhas são definidas como realidades espaciais onde a influência marítima atinge o interior, desencorajando tipos terrestres muito diferenciados (a não ser quando propiciados pelo relevo ou por condições tamanho específicas) e contrastes acentuados de temperatura e umidade (mesmo em ilhas relativamente áridas, onde a amplitude termo-higroscópica diuturna é superior à sazonalidade anual). A insularidade nutre-se da maritimidade. Daí, o clima insular, marítimo que é, qualifica-se como essencialmente ameno, não obstante sua suscetibilidade aos fenômenos (tufões ou furacões e outras sortes de tempestades tropicais, tsunamis, ação erosiva acentuada de ondas de grande energia, ventos frequentes) e atributos (maior sensibilidade à brisa aquática e às correntes marítimas, gradiente de pressão atmosférica e de temperatura entre as superfícies aquática e terral) particulares dos mares e oceanos.

De traço ameno, o clima marítimo incentiva a habitação, que, de seu lado, também depende, é claro, da situação geográfica - ilhas muito afastadas da costa tanto em termos físicos como em termos de acessibilidade (considerável distância-tempo e/ou distância-custo), mesmo que ofereçam um bom clima e uma vida aprazível, no caso de desastres naturais ou emergências humanas, oferecem menos vantagens de colonização. Todavia, se aliado a uma boa localização, um bom clima tende a favorecer a agricultura de exportação e o intrínseco comércio além-mar ${ }^{139}$. Afora que, 
atraindo os visitantes que demandam pelos frutos daquele solo, "as vantagens climáticas encorajam a densificação da população insular", incrementando a "busca pelo incomum, típico, das ilhas"140.

O princípio da continuidade terrestre é especialmente importante no caso das ilhas: por serem espaços diminutos, estão sujeitas aos efeitos dos sistemas oceânicos, tanto no que diz respeito aos aspectos climáticos como na ótica de outras características geográficas. Tal fato comprova-se não só na escala topográfica, comum nas análises nesográficas, mas também nas escalas geográficas, de maior expressão fenomênica. No quadro climático, as ilhas estão contempladas por climas locais engendrados pela ação marítima sem qualquer prejuízo para as escalas topoclimática (vertentes e porções da costa mais expostas a ventos e correntes marinhas tendem a ter características termo-higrométricas diferenciadas, afora a influição da geometria do modelado na taxa de radiação solar que atinge o solo) e sinótica (funcionamento de monções e outros sistemas de circulação atmosféricas, mobilidade dos centros báricos e consequente movimentação das massas de ar e, mesmo, das correntes marinhas, que tanta conta têm junto ao clima insular).

Atendendo às circunstâncias de que a umidade do ar e as precipitações atmosféricas são, em geral, mais abundantes nos oceanos, mares e costas e de que "a repartição das terras e dos mares exerce uma influência decisiva no regime dos ventos" ${ }^{\text {"141 }}$, reata-se, com certa facilidade, o raciocínio que bem associa maritimidade e insularidade. Constituem fatos determinantes da maritimidade: as diferenças de calor específico entre terra e mar influem na circulação atmosférica; o clima marinho possui maiores taxas de evaporação, que, por sua vez, tendem a rebaixar a temperatura; as massas líquidas distribuem o calor por correntes de convecção que conduzem a uma maior homogeneidade térmica se comparadas com as massas litólicas ou sedimentares; e, enfim, o ambiente oceânico minora a oscilação térmica anual e amplifica o período vegetativo ${ }^{142}$.

Como já demonstrado, as ilhas são, em termos de umidade, ambientes de viva interferência marítima, salvo ocasiões em que estão sob o efeito incisivo de sistemas de alta pressão atmosférica (como é o caso do arquipélago de Cabo Verde, cujo quadro climático está fortemente submetido ao anticiclone de Santa Helena) ${ }^{143}$. Disso, pode resultar, amiúde, uma vegetação relativamente exuberante. Uma vez que, se a umidade do solo "fornece diretamente a matéria-prima da seiva, a umidade do ar regula tanto a transpiração das folhas quanto a evaporação física" ${ }^{144}$.

Enfim, se a forma e as características topográficas de uma ilha favorecem pequenos ambientes microclimáticos, mais instável é o ambiente insular como um todo e, por conseguinte,

140 Ibidem, p. 452-453, tradução nossa

141 DE MARTONNE, Op. cit., p. 111, tradução nossa

142 Ibidem, p. 108-109

143 BABAU et. al., 1983, p. 76

144 DE MARTONNE, Op. cit., p. 754, tradução nossa 
mais desfavorável é para o desenvolvimento de certas espécies ${ }^{145}$. Sem dúvida, a autoridade do mar sobre a terra faz das ilhas, repetitivamente, espaços de menor heterogeneidade, de um lado, e maior suscetibilidade, de outro, quando confrontados com os ambientes estáveis contidos no imo continental.

\section{Perspectivas biogeográfica e ecológica}

Já figura como questão clássica e como matéria de polêmica da Biogeografia que "uma área larga estimula a diferenciação por apresentar uma grande diversidade de condições naturais, cada uma das quais tendendo a produzir suas próprias espécies ou variedades"146. Trata-se da relação entre vida e área, quer sob o ângulo da disponibilidade de recursos, seja sob o prisma da dimensão espacial (e, para os mamíferos, territorial) da vida. Exiguidade de espaço, quando traduzida por menos recursos per capita, é fator de competição, seja intraespecífica, seja interespecífica. Além do mais, notando que é o Homo sapiens sapiens um animal (com todas as necessidades de espaço e de recursos comuns a outros animais), a luta por espaço entre as espécies e, no interior delas, entre os indivíduos, é, também, uma luta da espécie humana e entre os próprios homens. A valer, o espaço não é somente fonte de recursos (animais, vegetais, minerais, humanos, hídricos, energéticos); ele mesmo constitui um recurso (espaçamento e heterogeneidade de ambientes são fatores diretamente proporcionais à disponibilidade de hábitats para os animais, vegetais, protistas, fungos e bactérias e de territórios para as espécies dominadoras - dentre elas, o homem).

Frente à barreira do oceano, à maior singularidade ambiental, à dificuldade natural de se estabelecerem microambientes estáveis, à forte influência climática marítima e à recorrente intervenção da costa sobre o interior, "cada ilha pode ser considerada como um ecossistema individualizado" ${ }^{147}$, com todos os trunfos e prejuízos disso procedentes. À revelia dessa idiossincrasia, há alguns fatos, afora o espaço exíguo, que conferem certa tonalidade biogeográfica ao conceito de insularidade: a escassez (maior competição, menor espaço, raridade de recursos), o endemismo (fruto do isolamento, é, quiçá, a característica mais preponderante) e o arcaísmo (também decorrente do isolamento e, por conseguinte, do parco contato com novas espécies e com novas condições ambientais). Se a escassez biótica e o arcaísmo persistente são alvo recorrente de certames, o endemismo é fato mais incontroverso. Uma boa elucidação para este tópico é, talvez, a assertiva de que "o isolamento, por reduzir ou prevenir a intersecção de indivíduos com as

145 SARTORELLO, 2010, p. 37

146 SEMPLE, Op. cit., p. 169, tradução nossa

147 FURLAN, 1989, p. 13 
características normais de uma espécie, tende a produzir divergências" ${ }^{148}$. Para bem realçar, dado que, "nas ilhas, há muitos casos de uma indubitável restrição de espécies a uma área diminuta" 149 , o nanismo, o gigantismo e o endemismo são consequências naturais dessa insularidade, já porque o mar parece oferecer-se como obstáculo de difícil transposição (principal fator apontado pelo naturalista Wallace), já porque, em algumas ilhas, as condições geográficas são tão específicas que favorecem o particularismo biológico. Deste fato final, recorda-se que condições específicas adversas sugerem, inversamente, escassez biótica e de recursos. Ora, na comparação com os continentes, o número de espécies e indivíduos de cada espécie é relativamente inferior nas ilhas, e suas relações com a terra são mais simples e diretas, uma vez que tais ambientes, além da área restrita, possuem fronteiras muito mais bem definidas. Na maioria dos casos, seus limites biológico e geográfico coincidem ${ }^{150}$.

Quando classificadas segundo a gênese geológica e a posição geográfica, ficam mais legíveis a forma e a origem da colonização insular, bem como os vínculos de sua biota com o continente. Com efeito, quanto mais recente sua origem e quanto mais próximas estão, maiores as chances de haver similitudes entre as duas terras emersas - a maior (continente) e a menor (ilha). Como é sabido, são dois os grupos de ilhas: as continentais e as oceânicas. As primeiras compartilham com o continente mamíferos e anfíbios. Já nas segundas, os animais e plantas que as habitam ou transpuseram a barreira marítima, ou, o que é mais provável, descendem de grupos que o fizeram anteriormente, quando as condições de transposição podiam contar com algum fator facilitador (nível do mar mais baixo durante um período glacial, por exemplo) ${ }^{151}$.

A famosa teoria do equilíbrio biogeográfico insular considera diferentes inter-relações entre três componentes do jogo espacial existente no interior das ilhas: em primeiro lugar, as qualidades das ilhas (tamanho pequeno, barreiras de dispersão e situação climática alterada); em segundo, os efeitos dessas qualidades na população (pouca variedade de hábitats e altas taxas de extinção como efeitos do tamanho pequeno; imigração reduzida e mecanismos diferenciados de dispersão como frutos da existência de barreiras geográficas; e alteração na estabilidade da população como seguimento à situação climática alterada); e, ao final, os efeitos na biota de modo geral (módico número de espécies em equilíbrio e altas taxas de renovação como repercussões da pouca variedade de hábitats, elevado número de extinções e imigração reduzida; variadas formas de seleção segundo a conjunção de certos efeitos na população). A resultante de tudo isso é, decerto, a evolução biológica. Duas são as naturezas de seleção: a $r$ (segundo a taxa intrínseca de crescimento, que seja,

148 SEMPLE, Op. cit., p. 411, tradução nossa

149 WALLACE, 1975 , p. 15, tradução nossa

150 Ibidem, p. 241

151 Ibidem, p. 242-245 
taxa per capita de um crescimento de relações em dado ambiente) e a $k$ (de acordo com a capacidade de carga do ambiente, isto é, número de indivíduos de uma população de dada espécie numa situação de equilíbrio populacional). Sem embargo, sempre que a população for maior que a capacidade de carga, o número de indivíduos decresce. Finalmente, o modo de seleção, atuando numa biota reduzida e num hábitat simplificado, determina alterações das formas insulares - o balanço $r \times k$ (entre a taxa intrínseca de crescimento e a capacidade de carga do ambiente) institui ganhos de seleção. Aí está o equilíbrio biogeográfico insular ${ }^{152}$.

Dessa teoria, provém outra constatação: quanto mais distante uma ilha de outra terra emersa, mais difícil o deslocamento da biota entre os espaços terrais ${ }^{153}$. No caso dos arquipélagos, ilhas existentes entre uma terra emersa $X$ e a ilha-alvo $Y$ podem servir de pontos de parada da biota, favorecendo a rota migratória e, consequentemente, a colonização de $Y^{154}$. Não obstante, com o desenrolar dos estudos, discerniram-se situações não previstas pela teoria, dentre as quais as duas seguintes: espécies diferentes podem ter efeitos ambientais desiguais (o comportamento de um bioindicador distingue-se do de uma espécie generalista); e, por vezes, pesa mais a diversidade de ambientes que a ilha suporta do que propriamente o tamanho da ilha ${ }^{155}$.

Não só em outros aspectos, mas especificamente como ambientes de florescimento biótico, as ilhas valem-se de dois sentidos: um absoluto (quando verdadeiras terras emersas cercadas de água por todos os lados) e um relativo (quando hábitats peculiares, com incisivo contraste em relação aos ambientes circundantes) ${ }^{156}$. Desse modo, mesmo no interior de uma terra emersa, as condições geográficas podem ser tão antinômicas que uma miríade de ambientes ecológicos irrompe-se como verdadeiro arquipélago em meio a um oceano rochoso.

Em síntese, o isolamento marítimo oferece, por corolário na realidade insular, o endemismo e, com certa frequência, a rarefação populacional. Além de tanto, a evolução de sua biota depende de uma paridade entre a taxa de crescimento e a capacidade de carga. E, no final, se, sob os primas fisiográfico e climático, a vinculação costa-interior é vigorosa, o mesmo pode ser dito para os fenômenos biológicos, haja vista que, não raro, as teias alimentares insular e marítima adjacente convergem em diversos níveis ou cadeias. Também, por si mesmas, as costas funcionam como linhas de contato biótico: presença de laminárias (algas castanhas ou feofícias), peixes (locais e, às vezes, distantes) e moluscos (mariscos). Como desdobramento a essa qualidade convergente, os

152 MACARTHUR e WILSON, 2001, p. 6

153 Ibidem, p. 126

154 Ibidem, p. 137

155 FURLAN, 1997, p. 41-42

156 WHITTAKER e FERNÁNDEZ-PALACIOS, Op. cit., p.10 
litorais ornam-se de depósitos de guano e conchas, atividades aquacultoras (e suas variantes de carnicicultura e maricultura) e vestígios de atracadouros para embarcações ${ }^{157}$.

As ilhas são ambientes essencialmente frágeis. Tornados ecossistemas relativamente desafiadores para a biota, em virtude da privação espacial e da segregação oceânica ${ }^{158}$, os espaços insulares possuem, em média, condições específicas e episódicas ${ }^{159}$. De mais a mais, como a escassez biótica é diretamente proporcional à distância da ilha ao continente e inversamente proporcional à sua área, o mesmo sucede à rarefação de recursos para a atividade econômica ${ }^{160}$.

Dentre as principais causas da vulnerabilidade ambiental insular, mencionam-se ${ }^{161}$ : pobreza de espécies (mais nichos espaciais vacantes e menor competição com espécies nativas), evolução isolada (espécies insulares são competitivamente inferiores às continentais), exagerada liberdade ecológica (espécies alógenas, muitas vezes, alcançam as ilhas sem pestes ou doenças, com vantagem sobre as nativas), colonização precoce (nas ilhas com longo histórico de ocupação humana, muito já foi devastado, perturbado e introduzido) e pequena escala (limitação de área significa pouca heterogeneidade de condições físicas para fazer frente aos impactos antropogênicos). Dependendo do caso, a essas características, soma-se a circunstância de serem pontos nevrálgicos do transporte intercontinental, o que enseja constantes perturbações e introduções de espécies exóticas. Também merecem referência a maior tendência a composições endêmicas, a fragilidade das formações naturais de pequenas dimensões, o particularismo das atividades humanas e os empecilhos ao desenvolvimento econômico duradouro (tirania das distâncias, raridade de recursos, carência de infraestrutura adequada e, em alguns casos, de, até mesmo, capital humano) ${ }^{162}$. Com efeito, frente a esses ambientes ecologicamente frágeis, há a necessidade de cooperação, em que os particularismos de cada ilha - dependendo da perspectiva, constrangimentos ou trunfos -, se usados de maneira combinada por meio da reunião de múltiplas realidades insulares, podem, porventura, fazer florescer um peculiar processo de desenvolvimento.

$\mathrm{Na}$ condição de lugares naturalmente protegidos, as ilhas "servem frequentemente de refúgio ou asilo para os fracos e vencidos, sendo, portanto, concebidas como apartadas do movimento histórico" 163 . Também constituem ambientes para idosos, cansados e, até mesmo, turistas, aventureiros e casais apaixonados. E, a sério, uma vez que se afastam da dinâmica comum do mundo, as ilhas, se, bem recentemente, foram úteis presídios, campos de trabalho, asilos e lazaretos (daí sua face, de quando em quando, tirânica), também podem convir às atividades 157 BRUNET, 2001, p. 257

158 FURLAN, 1989 , p. 13

159 DE MARTONNE, Op. cit., p. 265

160 SEMPLE, Op. cit., p. 444

161 CRONK e FULLER, 1995 apud WHITTAKER e FERNÁNDEZ-PALACIOS, Op. cit., p. 320

162 DOUMENGE e MONNIER, 1989, p. 7

163 SEMPLE, Op. cit., p. 438, tradução nossa 
turísticas, estando aí um potencial de crescimento econômico e, quem sabe, de aperfeiçoamento nas condições de vida da população.

\section{E. Perspectiva locacional}

A literatura geográfica tradicional sempre associou localização e insularidade ${ }^{164}$. Assim, não é de hoje que se concebe esta última como uma condição de "localizações naturais claramente definidas, nas quais as barreiras das montanhas e dos mares desenharam limites e garantiram certo grau de isolamento"165. Há de se evocar que a localização insular é, antes de mais nada, uma localização natural, mesmo que, doravante, adquira novos sentidos segundo a acessibilidade a outras terras e o posicionamento frente às rotas marítimas. Contudo, as distâncias podem encurtarse dependendo dos contextos - a inserção de uma ilha em uma rota comercial ou de transporte de passageiros, a instalação de um aeroporto, a conversão de seu espaço econômico em plataforma de investimentos, tudo isso pode esmagar a tirania da distância e, por conseguinte, conferir cosmopolitismo e mutabilidade ao espaço insular, antes arcaico e isolado. Caso esteja próxima à costa ou sua posição frente a outras terras seja tal que a soledade não possa se manifestar, a ilha pode até descaracterizar-se - pelo menos no sentido locacional. Este é o exemplo das ilhas-capitais brasileiras (de São Luís, de Vitória, de Santa Catarina), onde o elo continental quase anula a barreira aquática entre as terras.

Dessa forma, caso se assuma a localização em um sentido relativo (para além de uma localização absoluta, amarrada em um sistema de referência externo ao observador), as ilhas admitem duas possibilidades: isolamento ou inserção nas redes de circulação e comunicação. No primeiro caso, se a segregação pode prejudicar o intercâmbio dos ilhéus com outros povos (usualmente, fomentador de modificações sociais), por outro lado, consegue conduzi-los a se valerem, de maneira genuína, das vantagens dos ambientes onde vivem sem qualquer interferência. Na segunda ocasião, "uma localização nodal em rotas comerciais insere o cosmopolitismo nas ilhas, já em oposição à diferenciação étnica e à unidade que advém da situação oceânica de isolamento" ${ }^{166}$. Sem embargo, ousa-se deliberar que, não raro, o recurso mais importante para o desenvolvimento insular não está em seus minérios, em sua biota ou na fertilidade de suas terras, mas, como parece cada vez mais evidente, em sua localização.

Quando admitida a distância relativa, torna-se, juntamente, mais imediata a compreensão daquilo que se denomina sentido arquipelágico. Pois, se os constrangimentos e possibilidades 
impostos pelo oceano marcam a insularidade interna e externamente, é o jogo terra-água num conjunto de ilhas que define a existência ou não de um arquipélago. Com efeito, as distâncias relativas e o grau de sinergia entre as ilhas fomentam ou não uma unidade geográfica, o arquipélago, tomado aqui no seu sentido mais completo, isto é, numa acepção híbrida, que inclui o natural e o social para fundi-los inexoravelmente. Deriva-se daí que, na qualidade de manifestação espacial, a insularidade permeia-se de inúmeras escalas, materializando "não só a distância, como também o espaço de contato" 167 . Em um nível de análise internacional, o universo insular existe em oposição aos continentes, quer servindo a eles como aglomerado de nós do sistema de redes e fluxos que configura a economia-mundo, quer deles apartando-se, constituindo-se, assim, exceção da aldeia global. Enfim, já na escala dos países e regiões, já na escala dos arquipélagos e mares interiores, insularismo é particularidade, seja num sentido econômico, seja num sentido social.

\section{F. Perspectivas perceptiva e cultural}

Observação supracitada, uma boa localização (mais em um sentido relativo do que justamente absoluto) tende a compensar as limitações de área impostas pela realidade insular. Não constitui exagero, do mesmo modo que apartamento biótico acarreta endemismo, ausência ou exiguidade de contato entre povos enseja particularismo e localismo. Com efeito, se especificidades étnicas são maiores à medida que uma ilha é mais isolada, inversamente, quando próxima à outra terra, similitudes são bem possíveis ${ }^{168}$. Isso justifica o fato, por vezes observado, de a diversidade cultural ser comparativamente superior nos arquipélagos que no interior de uma área continental bem servida de redes de circulação e comunicação. Citando caso análogo, se uma ilha tende a cultivar uma nova língua ou, como é mais comum, um dialeto, um arquipélago apresenta um grupo de dialetos com diferenças expressivas entre as ilhas - se assim não fosse, os Açores e as ilhas de Cabo Verde não chamariam tanta a atenção dos gramáticos e linguistas. Já no caso das ilhas que constituem pontos nodais em uma rede de comunicação e circulação, há terreno fértil para o desenvolvimento de línguas francas ${ }^{169}$.

Afora a dimensão cultural objetiva, há um sentido subjetivo da insularidade, perpassado pela cultura (erudita e popular) de povo a povo, de geração em geração. A insularidade está, pois, atada à consciência dos ilhéus e dos não-ilhéus ${ }^{170}$. Desde os primórdios, as ilhas povoam a mente e o espírito dos homens - sua sensação, percepção e concepção.

167 PELLETIER, 2009, p. 230

168 SEMPLE, Op. cit., p. 418

169 LOPES, 1984, p. 47.

170 PÉRON, 1993, p. 18 
A ilha parece ter um lugar especial na imaginação do homem. Ao contrário da floresta tropical ou da praia, ela não pode reivindicar abundância ecológica, nem - como ambiente - teve uma grande significância na evolução humana. A sua importância reside no reino da imaginação. No mundo, muitas das cosmogonias começaram com o caos aquático: quando a terra emerge, necessariamente é uma ilha. (...) Ao contrário dos primeiros exploradores, Louis de Bouganville não acreditava em nenhum Éden, mas sua descrição maravilhosa do Taiti converteu a ilha em um substituto similar. (...) No século dezenove, os missionários [,entretanto,] rebateram a imagem edênica das ilhas (...) [e, apesar disso, elas] triunfaram sobre a propaganda negativa: a afluência dos turistas continuou. Elas adquiriram outro significado, local de fuga temporária. (TUAN, 1980, p.135-137).

Sem dúvida, o que mais se destaca na percepção do homem quanto ao espaço insular é, em rigor, seus limites bem delimitados pelo mar (ou por qualquer outro corpo d'água, no caso de ilhas fluviais ou lacustres). Se esses limites apartam o homem (pelo menos, em matéria de percepção) de outras possibilidades de ambiência, o mar (e, porque não, lago ou rio) torna-se seu ambiente por excelência. A resultante disso não é outra senão uma vida cotidiana distinta de uma vida continental ordinária, já porque o espaço é finito (donde deriva uma territorialidade bem circunscrita), já porque o oceano marca a paisagem e as práticas sociais (vinculação entre maritimidade e insularidade), já porque os meios de transporte são particulares, geralmente com graus acentuados de dissemelhança com os continentes ${ }^{171}$.

A "tomada de consciência de um modo de vida particular, diferente das populações continentais, está associada a um conjunto de representações e imagens que os ilhéus formaram a respeito de seu espaço geográfico e cultural, oriundas de sua insularidade" ${ }^{172}$. À vista disso, para além de uma insularidade geográfica, é forçoso admitir uma ilheidade psicológica (do francês, illeité $^{173}$ ), que seja, um sentimento, um imaginário, uma representação do espaço insular fortemente marcada por um localismo de personalidade, uma eutopia ou, em outros termos, uma "topopsicologia"174. Por sua vez, fatores como dimensão, distância (absoluta ou relativa) em relação à outra terra emersa e taxa de diversidade (de paisagens, produtos, homens e instituições) influenciam sobremaneira o localismo insular e a topopsicologia. A decorrência de todos esses fatos é que, de um lado, uma ilha torna-se mais perceptível (mais significativa) para um continental quanto maior sua distância ao continente e menor sua taxa de diversidade, e, de outro, a ilha participa da consciência de seu habitante quanto mais particular for, quanto mais tiver seus limites definidos e quanto mais constrangedores forem. Afinal, o implacável resultado desse particularismo 
é ou uma especialização funcional (ilhas agrícolas, ilhas-refúgio), ou uma idealização perceptiva (ilhas do medo, do amor, da aventura) ${ }^{175}$.

\section{G. Perspectiva econômica}

Afora uma taxonomia baseada em critérios físicos, como muito se viu, as ilhas podem ser catalogadas segundo seus usos - seja num sentido econômico (ilhas agrícolas, turísticas, portuárias, de entroncamento comercial e marítimo, paraísos fiscais), seja num entendimento social (ilhaspresídio, lazareto, de refúgio, santuários, paraísos ecológicos) - ou não-usos (ilhas efêmeras, fantasmas, de povoamento episódico ou sazonal) ${ }^{176}$. Com efeito, é por meio dos usos e não-usos que podem adquirir, quer por condições históricas, quer por condições naturais, que se é legítimo conferir um sentido econômico para as ilhas.

A exploração dos recursos haliêuticos e as oportunidades oferecidas pela costa sugerem duas facetas do aproveitamento econômico insular. Ora, se é a costa "a linha que limita o mar onde este parece invadir a terra" e, inversamente, se é também "a linha de frente da própria terra onde esta parece avançar sobre o mar" ${ }^{\prime 177}$, esse tropismo de dupla direção constitui um verdadeiro trunfo: do mesmo modo que o mar influencia a terra (climática e economicamente), a terra lança mão do mar para poder espraiar-se (navegações e exploração econômica das águas e do leito marinhos). Isso porque os litorais apresentam mais de um tipo de utilidade: são lugares de produção alimentícia ao mesmo tempo em que têm valor comercial por conectar povos de diferentes locais do mundo ${ }^{178}$.

Contudo, há que se reconhecer, é claro, que a insularidade, para mais que possíveis vantagens comparativas, tem um sem número de constrangimentos para a economia. Bem o sabem os chamados Pequenos Estados Insulares em Desenvolvimento (PEIDs) - como é o caso de Vanuatu, Barbados, Comores e Maldivas, para citar alguns exemplos. Neles, os efeitos do insularismo expressam-se em dois níveis ${ }^{179}$ : um macroeconômico (acentuada especialização econômica, grande dependência externa, vulnerabilidade ambiental expressiva, gastos públicos elevados) e um microeconômico (impactos nas atividades das empresas, em especial, no nível dos custos de produção, abastecimento, distribuição e venda). Frente a tais constrangimentos, diversas estratégias têm sido adotadas: algumas afastam-se do liberalismo global ${ }^{180}$ (ilhas isoladas, de tradições mais rígidas e sem a infraestrutura comum a outras partes do mundo, como Tristão da

175 Ibidem, p. 52-55

176 RÜE, Op. cit., p. 137

177 FEBVRE, Op. cit., p. 214

178 DOUMENGE, 1967, p. 32

179 ALMADA E SANTOS, 2011, p. 81-82

180 Ibidem, p. 81-82 
Cunha), enquanto outras vivem em função dele (Singapura, Hong Kong). Quer em um quadro, quer em outro, a cooperação parece ser a palavra-chave.

\section{H. Perspectivas social e demográfica}

As condições naturais que fazem a ilha manifestar sua insularidade possuem desdobramentos demográficos específicos. O tipo de costa, por exemplo, é, talvez, um bom parâmetro analítico da correlação espacial entre povoamento e condições geográficas. Já Ritter ${ }^{181}$ reconhecia duas qualidades de litoral: de condensação (onde a densidade humana é diretamente proporcional ao número de articulações, tais quais baías, enseadas, pontas e ilhas) e de dispersão (privadas de articulações costeiras, as aglomerações humanas procuram os estuários dos rios). Ademais, não apenas as articulações, mas os acidentes propriamente ditos parecem também favorecer ou embaraçar a ocupação. A valer, "a subsidência ou o movimento positivo do terreno mantém a costa num estado de juventude", de modo que a "riqueza das articulações é favorável ao assentamento humano, ao porto e a pesca", enquanto "a subsidência negativa tende a simplificar a drenagem e a dificultar o assentamento" "182. Com efeito, "não só a acessibilidade da costa em relação ao mar, mas também sua habitabilidade é um fator de importância histórica" ${ }^{183}$, visto que um interior infértil ou acidentado, uma costa fértil ou a combinação de ambos podem explicar uma superpopulação litoral (caso da China). Em vista disso, dois parecem ser os destinos insulares: a acessibilidade e a habitabilidade da ilha podem, individualmente ou de forma combinada, ensejar ou rarefação demográfica, ou superpopulação, quer seja na ilha de maneira geral, quer seja numa ilha específica dentro de um conjunto arquipelágico mais amplo, quer seja em ambientes particulares de uma mesma ilha (litoral, interior).

Outro aspecto que merece tratamento, já por sua dimensão tanto social quanto demográfica, é a relação entre emigração e permanência. No geral, como se pode pensar, localismo e segregação caminham juntos. Todavia, se o isolamento das ilhas tende a aumentar o localismo e a reforçar a identidade grupal dos ilhéus, os contornos marítimos cada vez mais navegáveis instigam, não raro, a evasão. De fato, nos atuais contextos do trabalho e do emprego no mundo globalizado, quanto mais voltados a si mesmos estiverem os espaços insulares (quanto maior seu coeficiente de insularidade), menos oportunidades oferecem e, em decorrência, mais reforçam seus contornos, mais valorizam o domínio além-mar. Aí está, sem dúvida, uma relação causal complexa: como o

181 CARVALHO, 1913, p. 33

182 DE MARTONNE, Op. cit., p. 20, tradução nossa

183 SEMPLE, Op. cit., p. 267, tradução nossa 
insularismo faz da ilha um conceito absolutamente eutópico ${ }^{184}$ e como a inclusão da ilha no contexto global tende a tornar essa eutopia uma desvantagem comparativa, pode desenvolver-se, no seio dos ilhéus, o tímido (ou, por vezes, mais explícito) desejo de virar-se para fora, de sair de seu isolamento tirânico e conquistar o ar de outras terras. A sério, a utopia continental aparece, no âmbito da somatória superlativa dos constrangimentos da insularidade, como o outro invertido, contradito e, curiosamente, alimentado pela eutopia insular.

\section{Perspectiva territorial}

Por ter seus limites naturalmente estabelecidos pelo mar, a ilha, de saída, pode reivindicar facilmente identidades territoriais, pois "unidade e divisão políticas procuram assentar-se sobre unidade e divisão geográficas" ${ }^{\prime 185}$. Ora, os limites físicos da soberania de uma nação tendem a reforçar sua posição de lugar único, que merece zelo ${ }^{186}$. Já no caso de um arquipélago, as fronteiras não são reconhecíveis tão prontamente, a não ser que um grupo de ilhas esteja completamente apartado no meio do mar e constitua, ele próprio, um único arquipélago.

De mais a mais, a presença do mar e de articulações na costa, bem como a posição de uma ilha ou um arquipélago no âmbito do jogo político local ou mundial, pode bem ser um trunfo em episódios de alianças, conquistas e guerras. Não se está sem razão quando se endossa, "nas formações políticas de grande envergadura, as posições marítimas, tais como ilhas e cabos, têm o seu papel destinado" 187 .

Em conferência do Programa das Nações Unidas para o Desenvolvimento ${ }^{188}$, congregaramse diferentes formas de existência territorial. Com efeito, nos vários rincões do globo, é possível identificar desde uma perinsularidade ou hipoinsularidade ${ }^{189}$ (continentalização de um fenômeno insular) até uma superinsularidade (isolamento total de uma ilha), bem como, em paralelo, desde uma uni-insularidade (Estado-ilha) até uma pluri-insularidade (Estado-arquipélago). Combinem-se a essas formas de insularidade, perfis econômicos distintos, e despontará aos PEIDs um quadro extremamente múltiplo de ilhas-território, que, uma vez integradas, podem granjear relevância crescente no cenário político e econômico internacional. Nesse contexto, citam-se, por exemplo, organizações como a AOSIS (Aliança dos Pequenos Estados Insulares) ${ }^{190}$.

184 GONÇALVES, 1986, p. 130

185 SEMPLE, Op. cit., p. 23, tradução nossa

186 TUAN, 1983 , p. 197

187 LA BLACHE, 1921, p. 360

188 Para mais informações, acesse: <http://www.undp.org/content/undp/fr/home/presscenter/events/2014/ september/smallislands2014.html >.

189 THIERRY, 2005, p. 329

190 Disponível em: <http://aosis.org/>. 


\section{CAPÍTULO III. MODELOS GRÁFICOS DE ILHAS E ARQUIPÉLAGOS}

A ilha ideal é um antimundo ${ }^{191}$. Espaço antissináptico, porque refratário às redes integradoras, a realidade insular possui, não raro, uma história contraditória. Se, antes, insinuava-se como conservação e endemismo, agora, assimilada a determinada trama regional ou mundial de circulação e comunicação, é paisagem em rápida mutação (quiçá, de descaracterização), tenha-se em vista sua parca capacidade de resiliência quando em um contexto de exiguidade e homogeneidade espaciais. Assim, do ponto de vista cartográfico, para determinar sua situação geográfica, faz-se necessário representar a ilha como ponto integrado ou banido das linhas de sinapse, e, para descrever seu sítio interior, como área de aspecto gráfico homogêneo (isotropia) ou repleta de dessemelhanças ou desproporções gráficas (anisotropia).

Com efeito, o modelo insular areolar baseia-se na circularidade litoral, perímetro que lhe dá unidade e definição. Isso porque a quase totalidade das ilhas vive em função de sua costa. Manifesta-se segundo sua relação com uma externalidade. Intestinamente, dissimetrias ocorrem entre a faixa litorânea e o interior terral, transmitindo, por vezes, relações centro-periferia. Frequentemente, em uma ilha, centro geométrico e centro humano não coincidem: é mais comum, aliás, que a periferia esteja no meio do espaço insular, na medida em que a centralidade é exercida pela franja costeira. Esses fatos, longe de serem acessórios, devem ser notados sempre que se empreenda representações de todos os tipos. Gradações ou diferenciações cromáticas, quando bem posicionadas numa imagem são, de seu lado, capazes de expressar graficamente níveis de penetração de influências externas, oposição litoral-interior e relação centro-periferia.

Por sua vez, as formas geométricas, os efeitos cromáticos e os sinais gráficos são dotados de capacidade representativa própria segundo os contextos em que são empregados, seja para demonstrar as relações espaciais mais significativas de uma ilha, seja para expressar as dinâmicas elementares de um arquipélago. Neste caso final, as hierarquias e interações entre ilhas-centro, ilhas-periferia e ilhas desertas devem possuir uma fisionomia própria em termos de figuras ${ }^{192}$.

Já o vimos, mas é necessário retomá-lo por constituir ponto nevrálgico do trabalho: quando preenchida por um modelo explicativo, uma estrutura (ou conjunto de estruturas) insinua uma forma. A valer, a forma da insularidade (aderente às formas da maritimidade, do litoralismo, da ilheidade e da condição arquipelágica) necessita de modelos gráficos para impor-se à vista do pesquisador. Esses modelos, no que lhes diz respeito, buscarão captar as estruturas espaciais fundamentais que, entre si, definam a localização umas das outras (configuração) e/ou componham,

191 BRUNET, 2001, p. 261

192 Ibidem, p. 262-263 
cada qual com sua contribuição, um todo fisiológico cognoscível (sistema). Com amparo na Coremática, buscamos apresentar modelos gráficos com algumas das estruturas que, vistas páginas atrás, auxiliam no entendimento da condição geográfica insular.

Como base, tenha-se a relação indissociável, sobretudo no campo da representação gráfica, entre Geometria e Geografia e, por conseguinte, a paridade proporcional entre propriedades geométricas $^{193}$ e propriedades geográficas. À vista disto, num modelo gráfico: igualdade de forma geométrica expressa igualdade de fenômenos (propriedade da congruência); igualdade de área expõe igualdade de magnitude (propriedade da equivalência); e, enfim, sobreposição de figuras insinua igualdade de lugar (propriedade da coincidência). Para citar o caso, tenham-se dois círculos próximos com tamanhos distintos. Quando a finalidade é representar a forma insular revelada pelas estruturas em um modelo gráfico, os dois círculos são espaços de mesma natureza (ambos constituem ilhas); sua distância geométrica é também geográfica (seja num sentido absoluto de localização geodésica, seja num sentido relativo de acessibilidade ou espaço de relação); e, ao cabo, os tamanhos diversos não indicam outra coisa que disparidades na área física ou na importância (econômica, política, social) de uma ilha em relação à outra.

Nas páginas subsequentes, apontam-se, primevamente, exemplos consagrados de modelização gráfica de ilhas e, ulteriormente, coremas que, num conjunto, poderiam compor um retrato da insularidade em suas nuances de manifestação.

193 EUCLIDES, Op. cit., p. 245-246 


\section{A. Exemplos da Revista M@ppemonde ${ }^{194}$}

Prova incontestável de que Coremática e Geografia Insular têm laços em comum há tempos é o conjunto de trabalhos aqui presente. Neles, é interessante notar a permanência de distintivos gráficos, possivelmente reaplicáveis em diversos outros espaços insulares.

\section{Nova Zelândia}

Lançando mão da modelização gráfica, Cognard (2012) retratou a Nova Zelândia sob a ótica de sua formação socioterritorial e subsequente integração ao sistema-mundo.

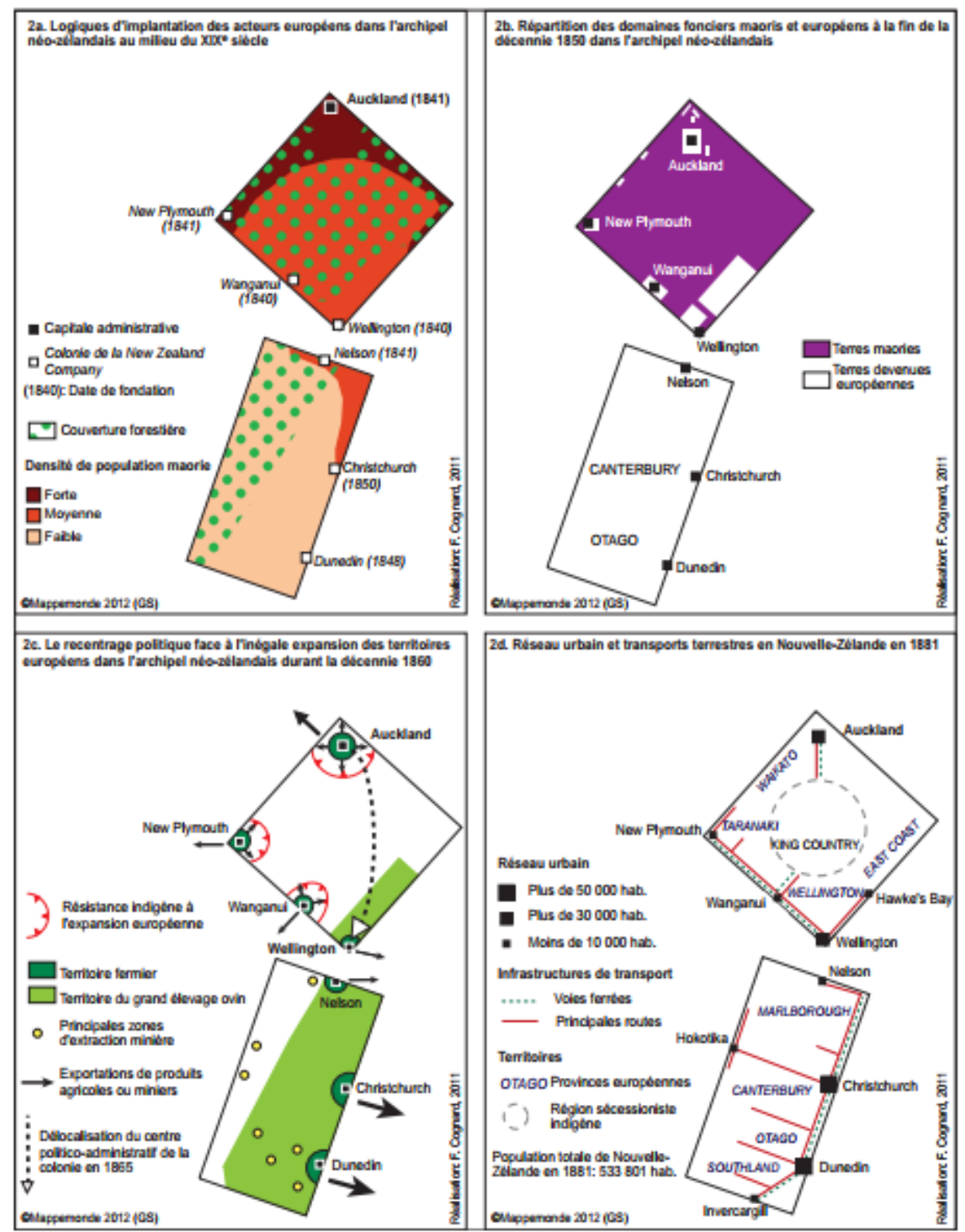

Figura 2. Modelos gráficos de ocupação e integração territorial da Nova Zelândia (COGNARD, 2012)

194 Para mais informações, acesse: <http://mappemonde.mgm.fr/>. 


\section{Córsega}

Brunet (2004) descreveu graficamente Córsega opondo, de um lado, situação geográfica montanhosa e mediterrânica e, de outro, dinâmicas históricas de ocupação e mutação.

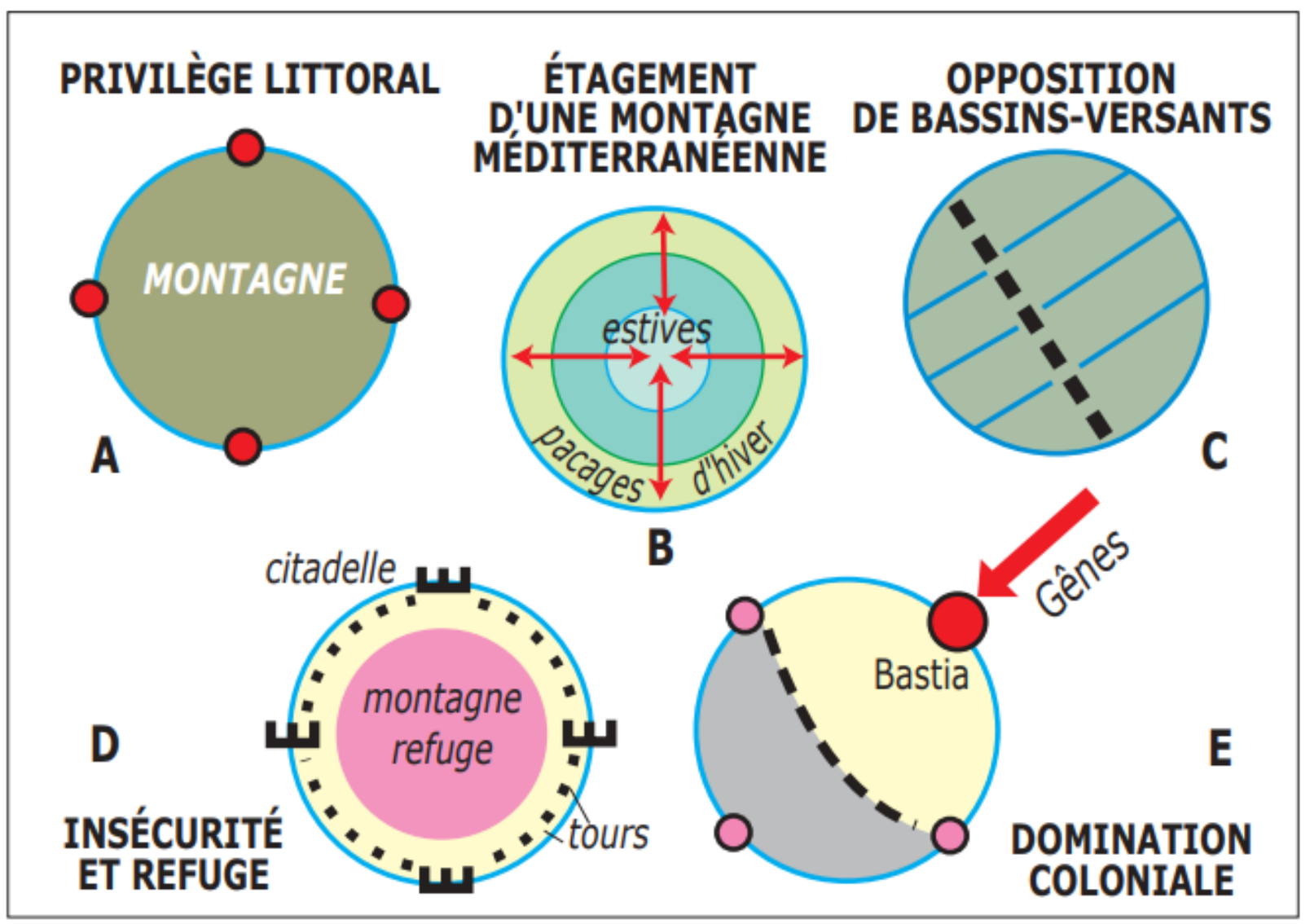

Figura 3. Modelos gráficos da ilha de Córsega (BRUNET, 2004) 


\section{Sri Lanka}

Já Neyroud (1993) combina relação centro-periferia, parcelamento étnico-cultural e movimentos de conquista territorial ao tratar do Sri Lanka.

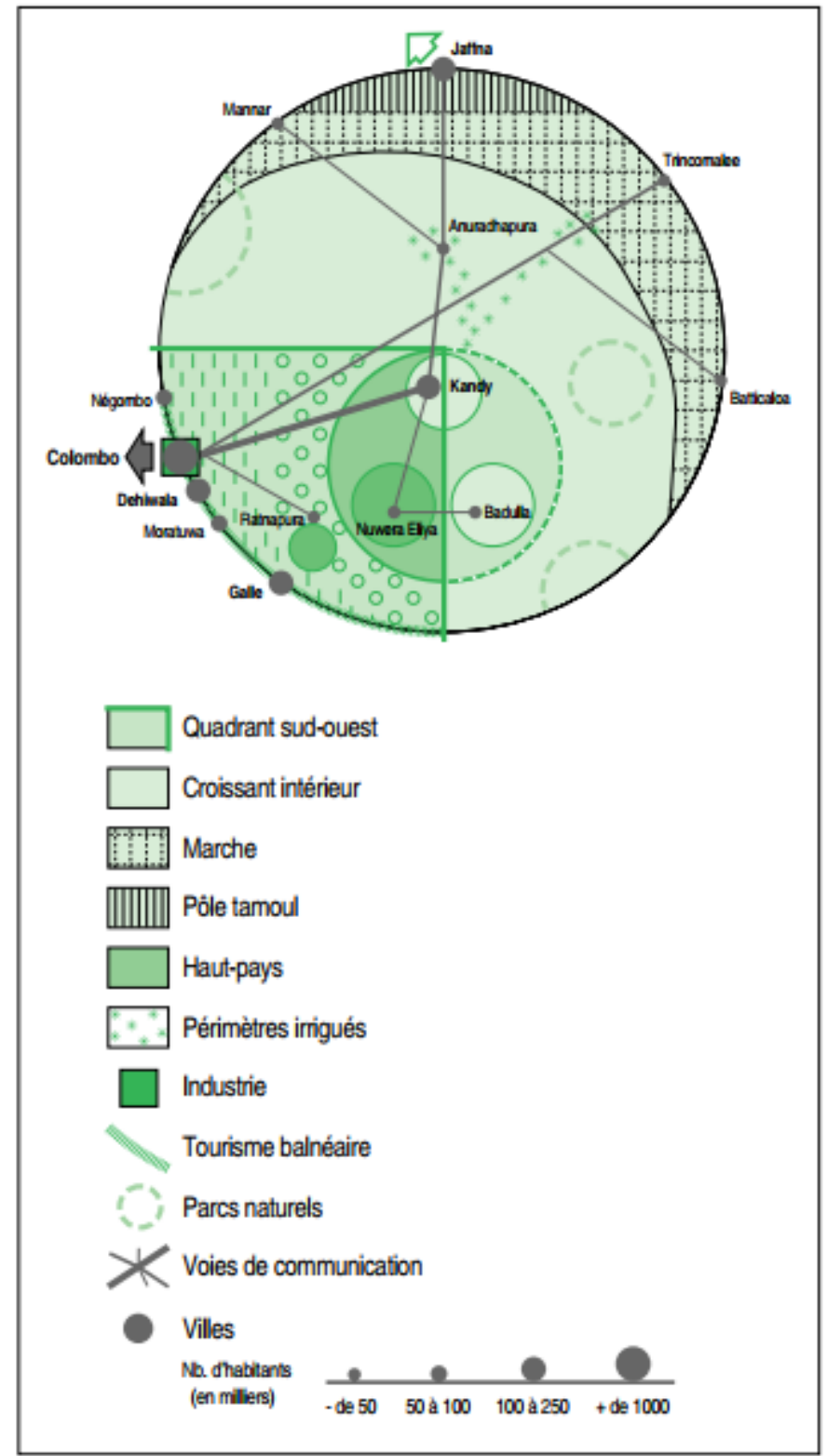

Figura 4. Modelo gráfico do Sri Lanka (NEYROUD, 1993) 


\section{Japão}

Domingo (1993) preocupou-se em representar o Japão em sua relação com a economiamundo.

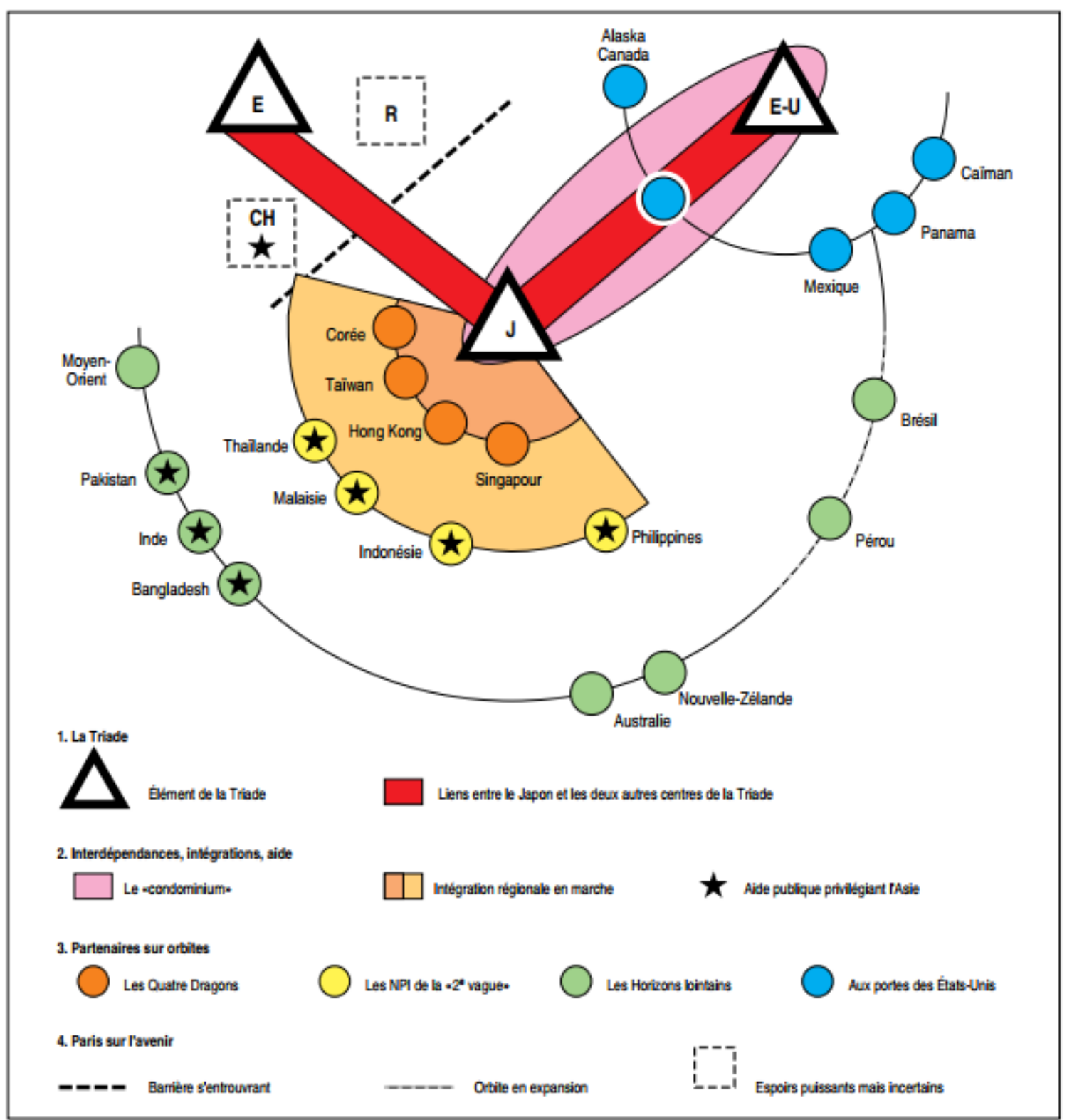

Figura 5. Modelo gráfico do Japão no contexto do fluxo mundial de capitais e mercadorias (DOMINGO, 1993) 


\section{Malásia}

Koninck e Théry (1989) analisaram a Malásia do ponto de vista de uma síntese complexa de quatro estruturas fundamentais em relação, duas antecedentes, duas consequentes.
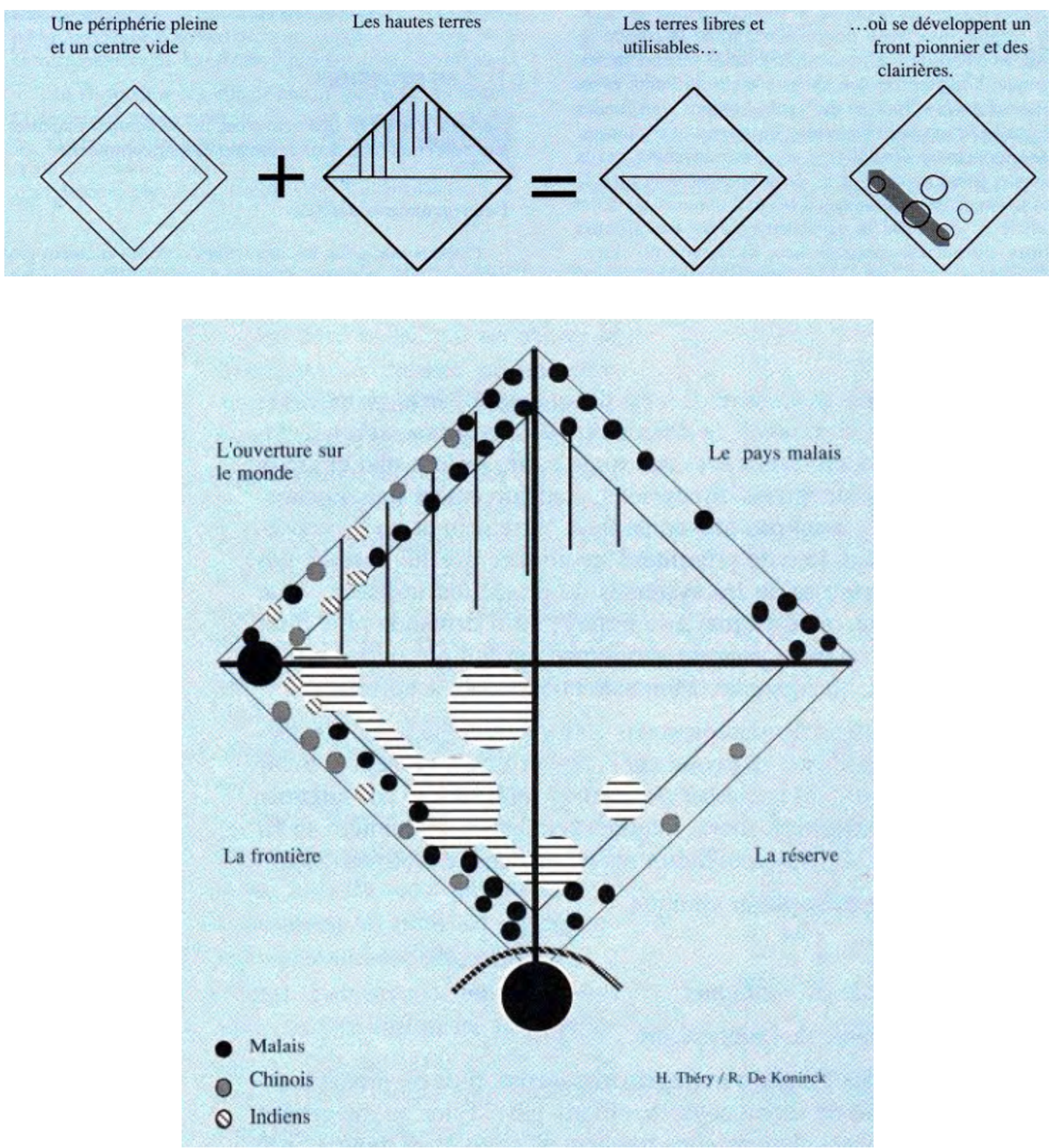

Figura 6. Modelos gráficos de análise e síntese retratando a Malásia (KONINCK e THÉRY, 1989) 


\section{Socotorá}

A organização espacial de Socotra (ou Socotorá), no Índico, está repleta de dissimetrias e hierarquias numa franja costeira destoante do pilar tectônico interior, parcamente habitado, porém fonte dos escassos recursos hídricos da ilha. Isso quem expõe é Guébourg (2000).

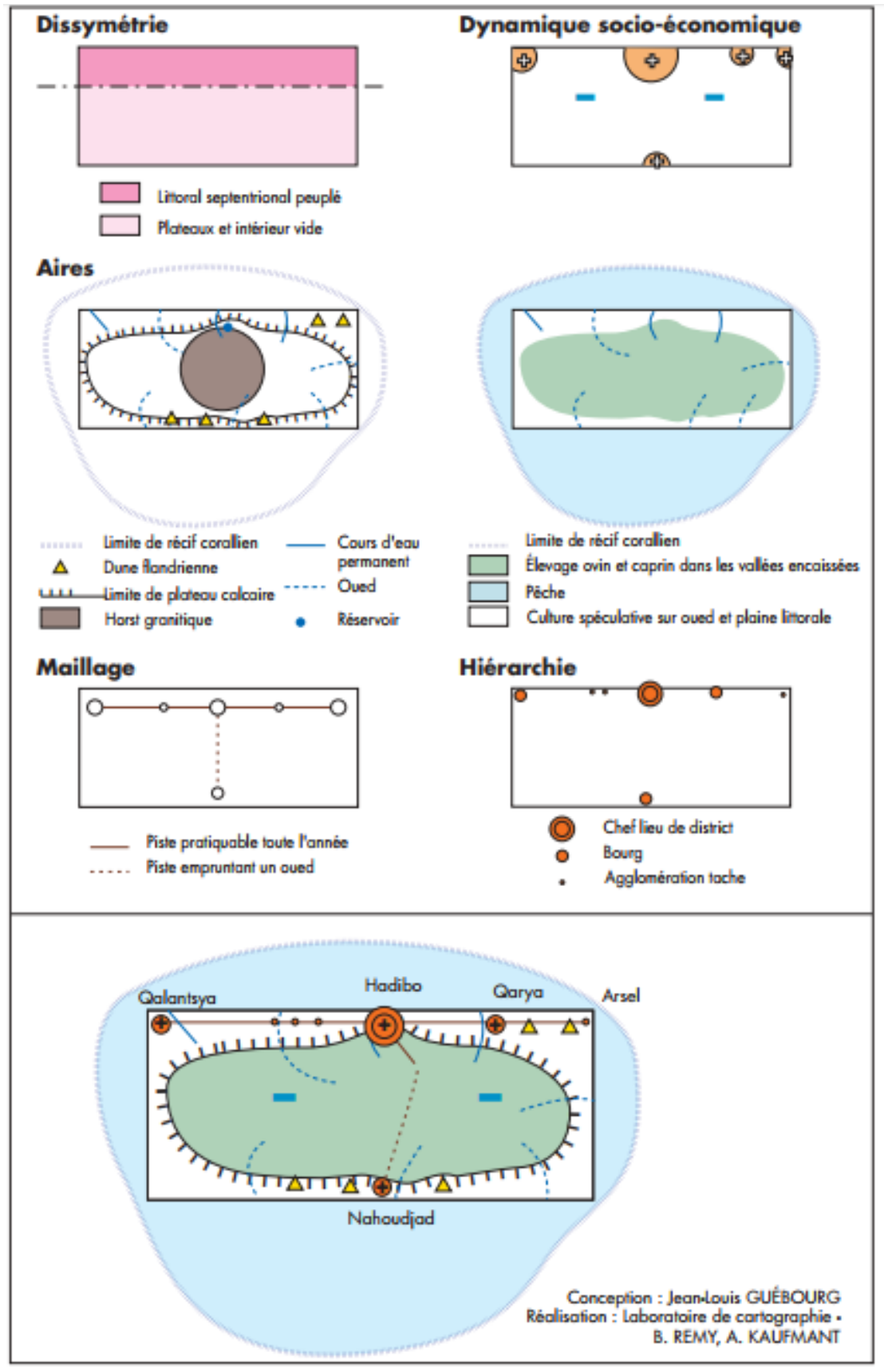

Figura 7. Modelos gráficos de análise e síntese retratando a ilha de Socotorá (GUÉBOURG, 2000) 


\section{Tenerife}

O relevo também é relevante no exercício de Jadé (2000), que empreendeu uma modelização gráfica da ilha de Tenerife, no arquipélago das Canárias.
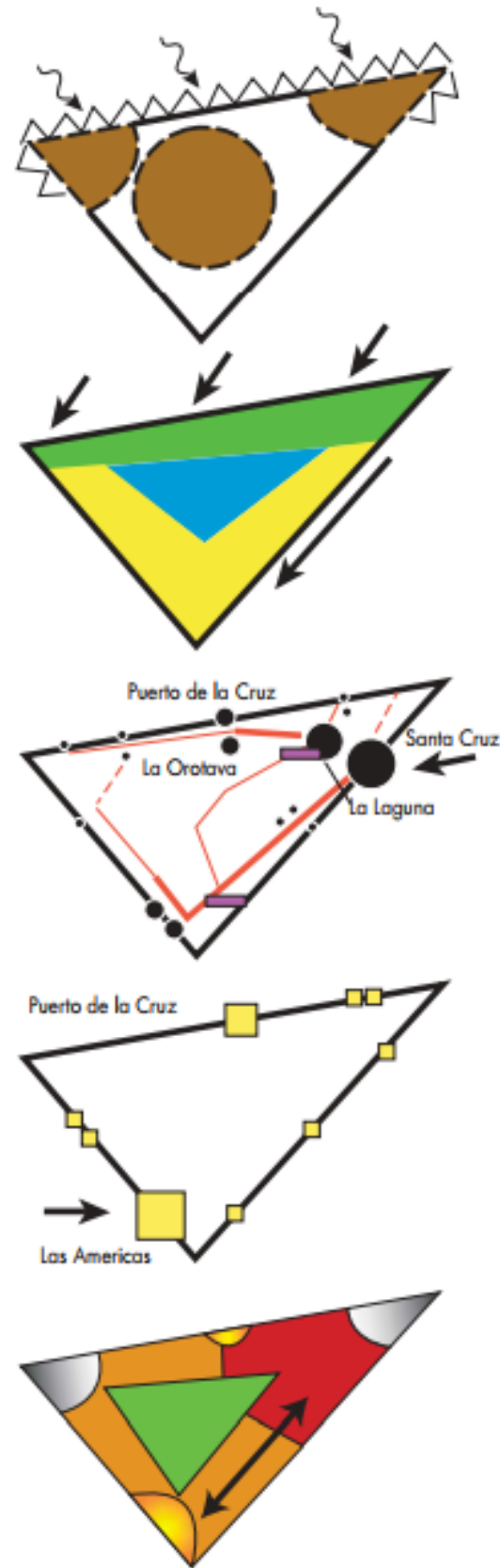

Erwann bode
Relief ef liftoraux

Les reliefs volkaniques elevés et dissóqués

Direction des houles dominantes

Cótes à falaises exposibes aux houles

\section{Climat, précipitations}

Alizés dominants

Précipilations abondantes, croissartes vers Pintérieur

Climat d'alitude, froid, sec, avec parfois de la neige Cóte sous le vent, bon ensoleillement, effet de foehn

\section{Réseau urbain}

Un système urbain hiérarchisé et constitué d'unités bipolaires

Les principales voies de communication, sur le liftord oriental

Deux oéroports : vols internationoux ou sud, domestiques à la laguno

Les flux d'importations, la dépendance de l'ille

\section{Tourisme}

Les principaux pöles touristiques, centrés sur des aménagements liftoraux : le modèle ex nihilo, conçu pour solisfaire à l'imoginaire européen

Desination des principaux flux touristiques

\section{Organisation de l'espace}

Les espoces areduss des massifs éleviés : difficulté d'accès et paysoges superbes

Le pare nutional du Teide

L'espoce de vie des finerfeniens : grignoté par la périurbanisation, la banlieue bleue de Santa Cruz.

Les espoces intermédiaires : vocation agricole en déclin au nord, forte pression fouristique au sud.

Les isolats du tourisme international

Les flux pendulaires entre espace de vie tinerfenien et pöle demplois touristiques

Figura 8. Modelos gráficos da ilha de Tenerife (JADÉ, 2000) 


\section{Comores}

A descontinuidade típica dos arquipélagos adquire relevância e interesse neste trabalho, já porque se alicerça em outros modos de implantação que não o zonal, já porque carece de maior atenção para ser percebida, no contexto da representação, como uma unidade geográfica única. Acerca do fato, Gay (2001) traz o exemplo das ilhas Comores como modelo de difusão do turismo em arquipélagos intertropicais. O mesmo autor lida com a implantação do turismo em outras ilhas: Barbados, Martinica, Taiti, Mahé (Seicheles) e Viti Levu (Fiji) ${ }^{195}$.

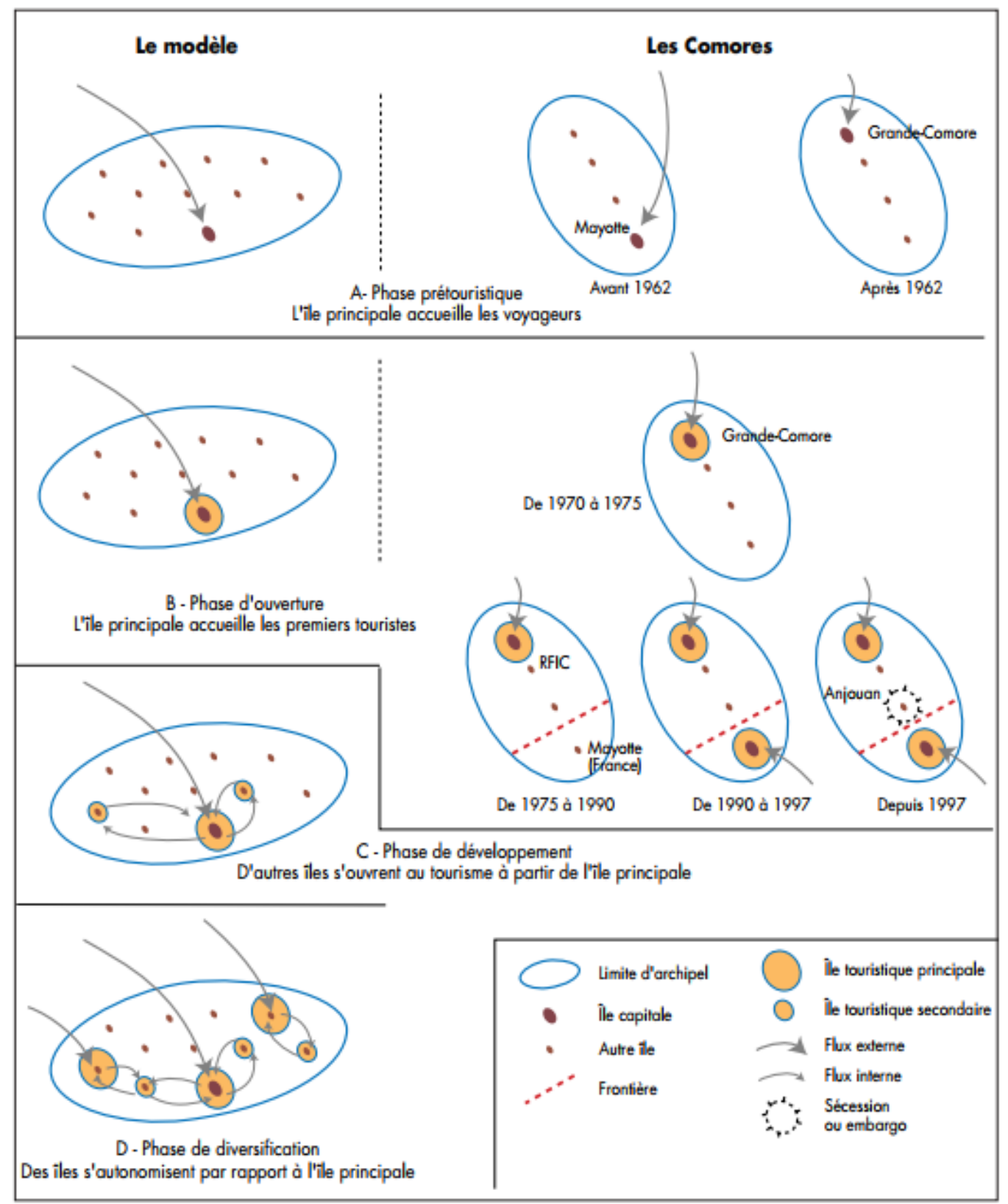

Figura 9. Modelos gráficos da difusão do turismo no arquipélago de Comores (GAY, 2001)

195 Idem, 2000 


\section{Maurício, Reunião, Martinica e Guadalupe}

Aliás, como no caso imediato supracitado, tendo-se em vista a difusão da Coremática na Geografia francesa, as possessões atuais ou os pretéritos territórios de ultramar da França são comumente eleitos estudos de caso para a modelização gráfica. A valer, sobre a ilha de Reunião, há os trabalhos de Jauze (1996), de Bouchet e Gay (1998) e de Guébourg e Théry (1988). Também é matéria de Knafou (1988) e de Couix e Desse (1992), que, para uma análise comparativa, colocamna lado a lado de, respectivamente, Maurício e Guadalupe. Aliás, tanto Calmont e Vassoigne (1999) como o próprio Brunet (1986) contam com estudos de Martinica e/ou Guadalupe em suas obras.

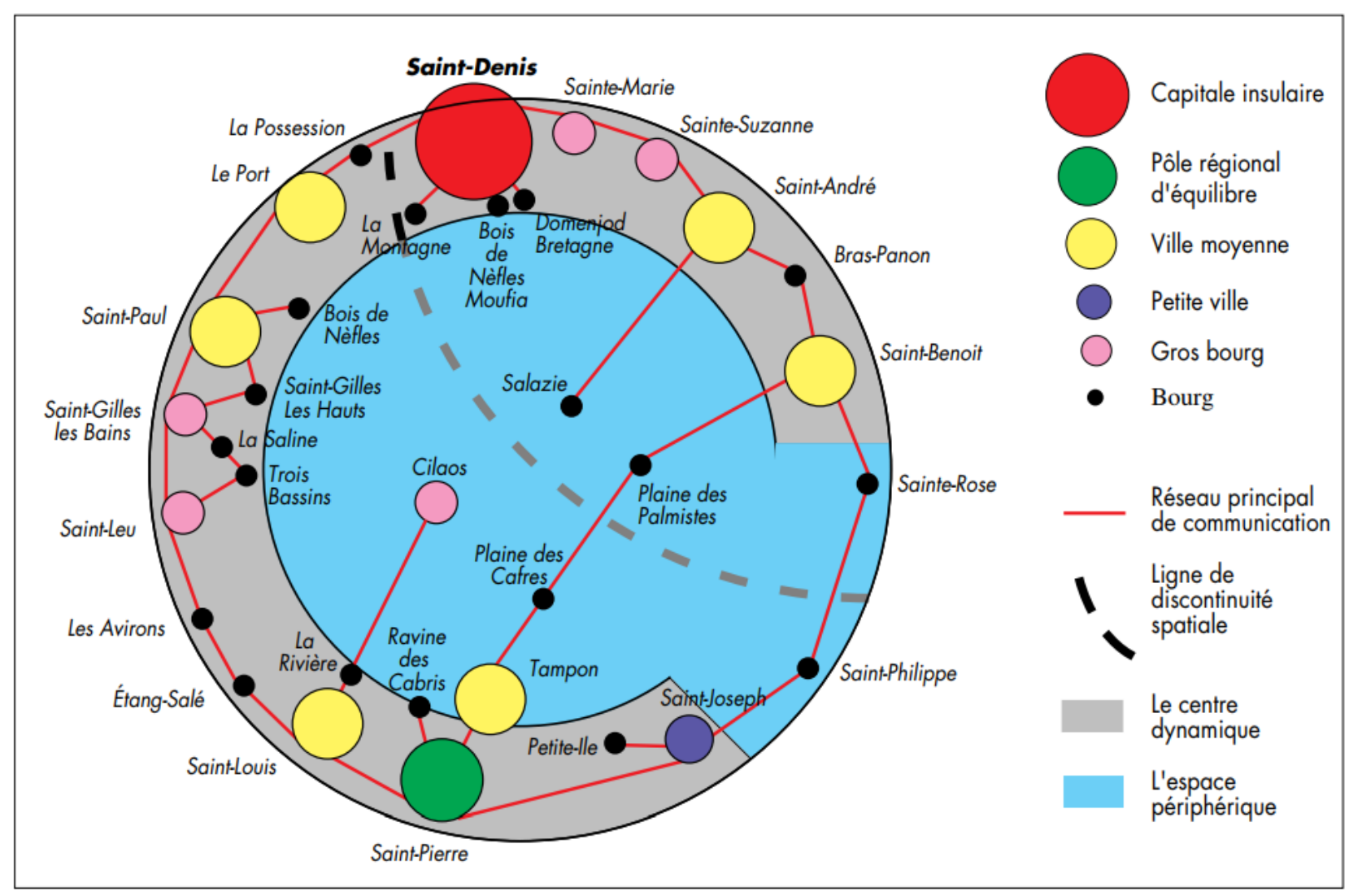

Figura 10. Modelo gráfico da ilha de Reunião (JAUZE, 1996) 

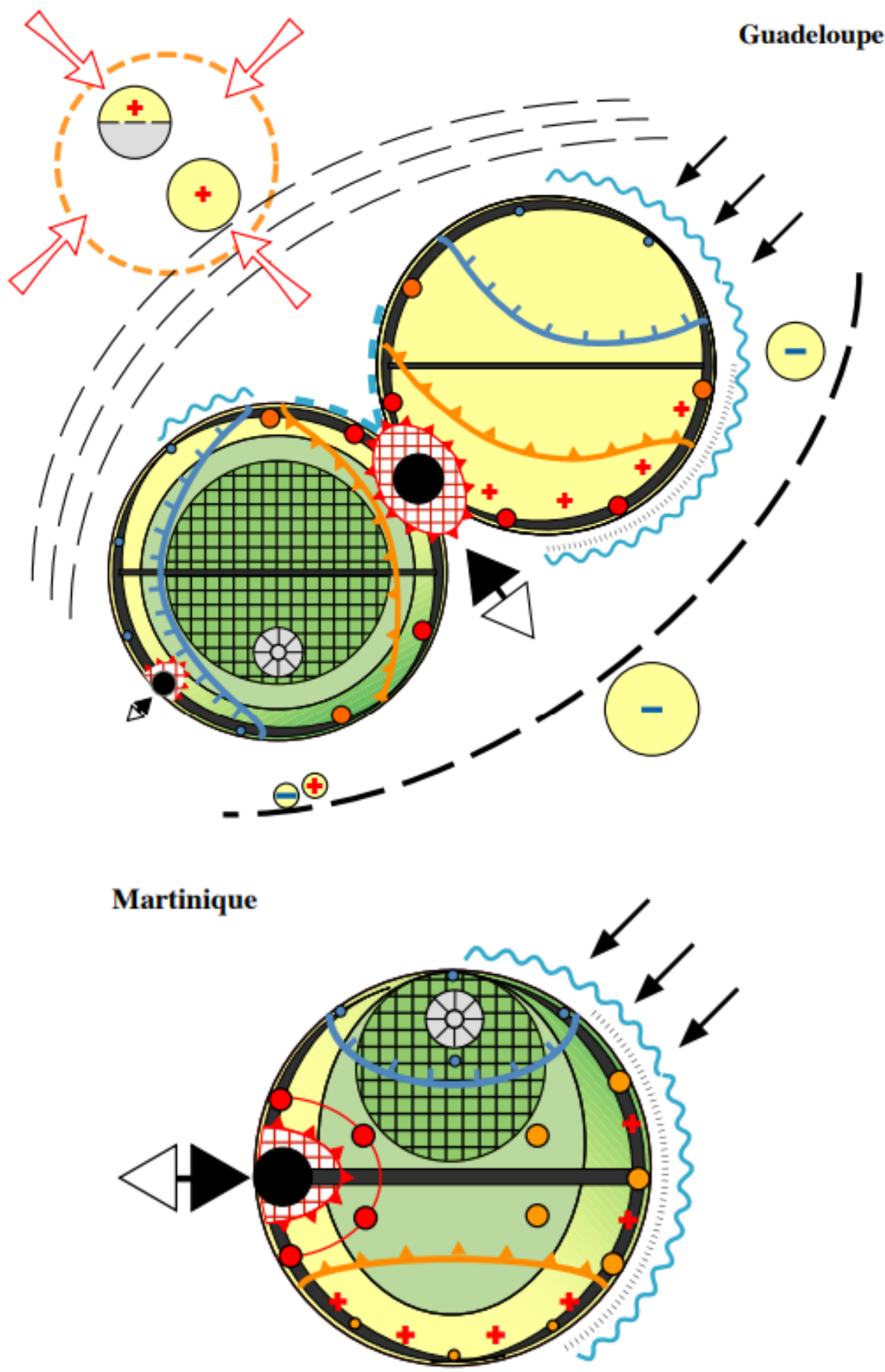

Antilles

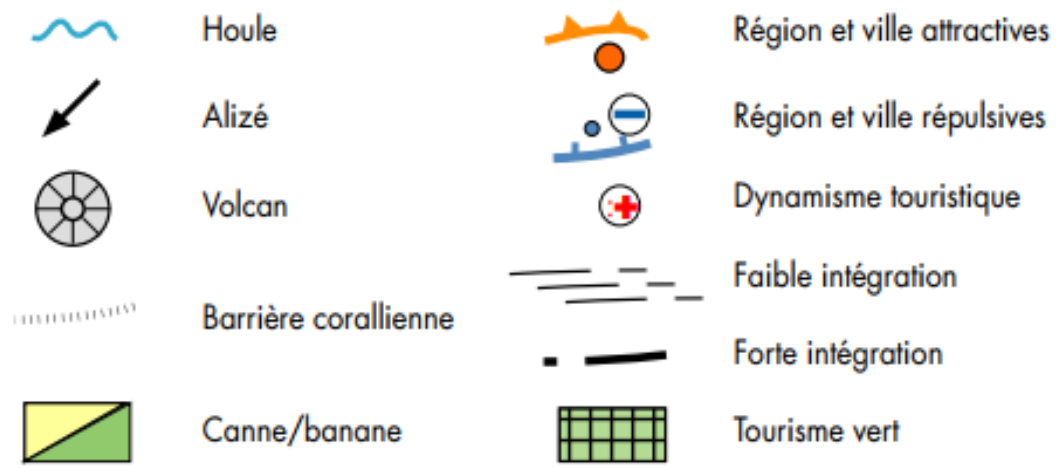

Figura 11. Modelos gráficos comparativos de Guadalupe e Martinica (CALMONT e VASSOIGNE, 1999) 


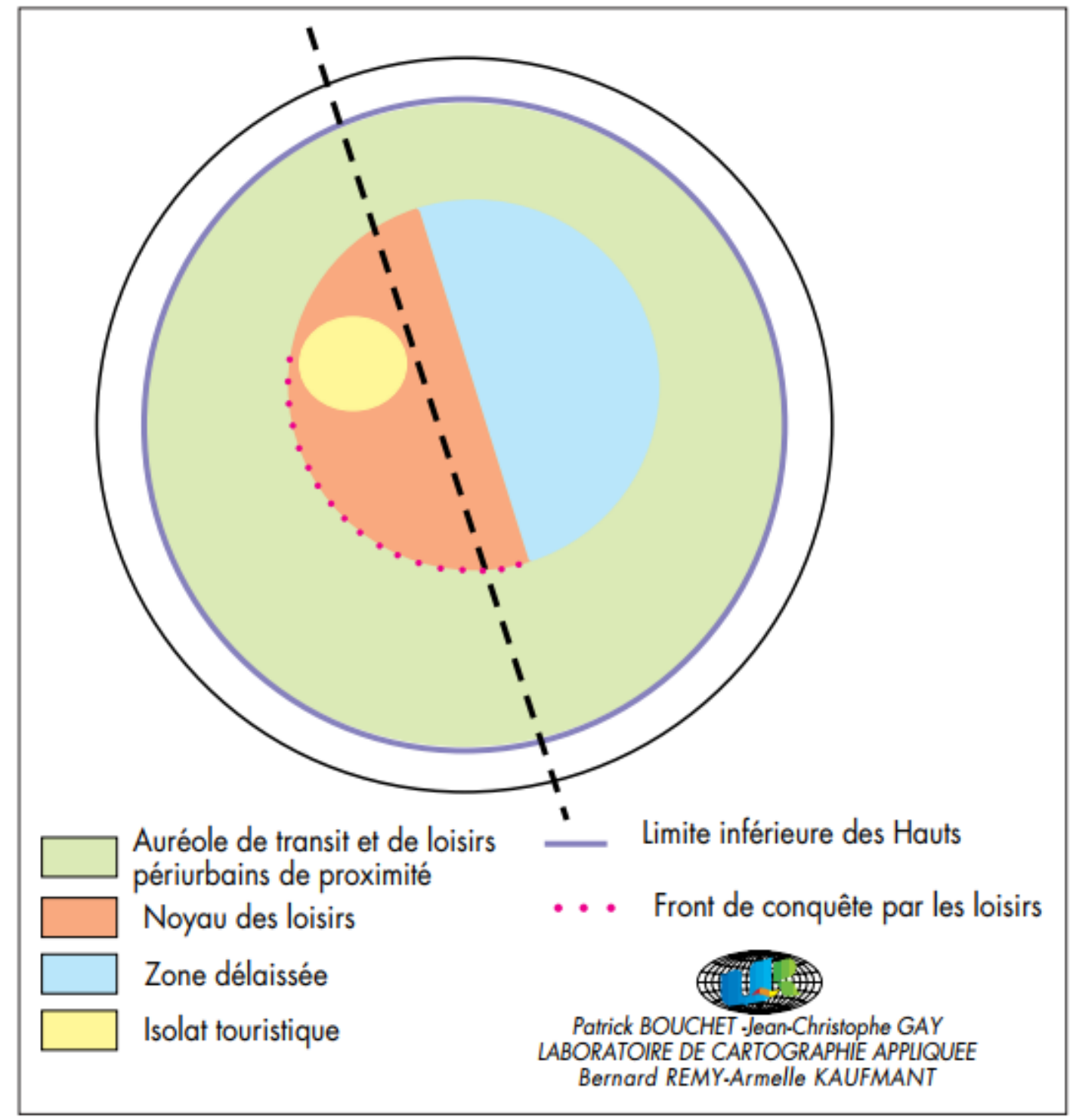

Figura 12. Modelo gráfico da organização do espaço turístico na ilha de Reunião (BOUCHET e GAY, 1998)

\section{LA REUNION}
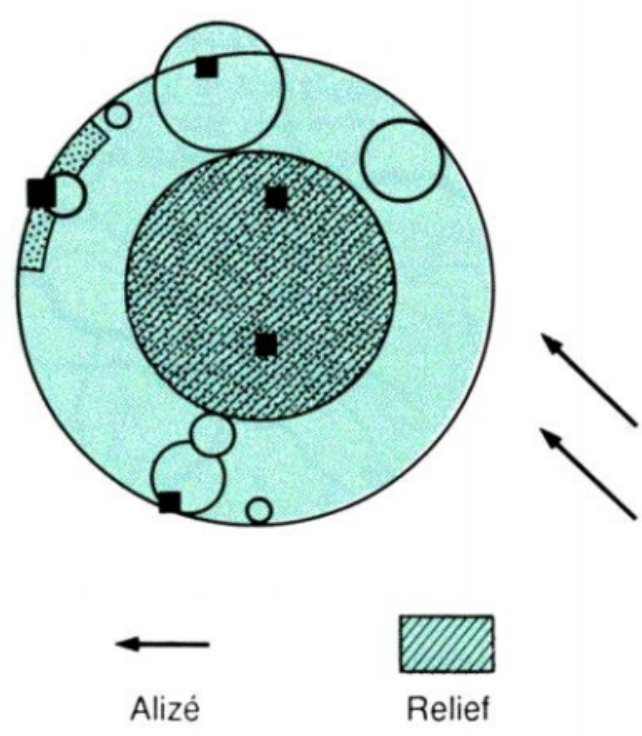

MAURICE
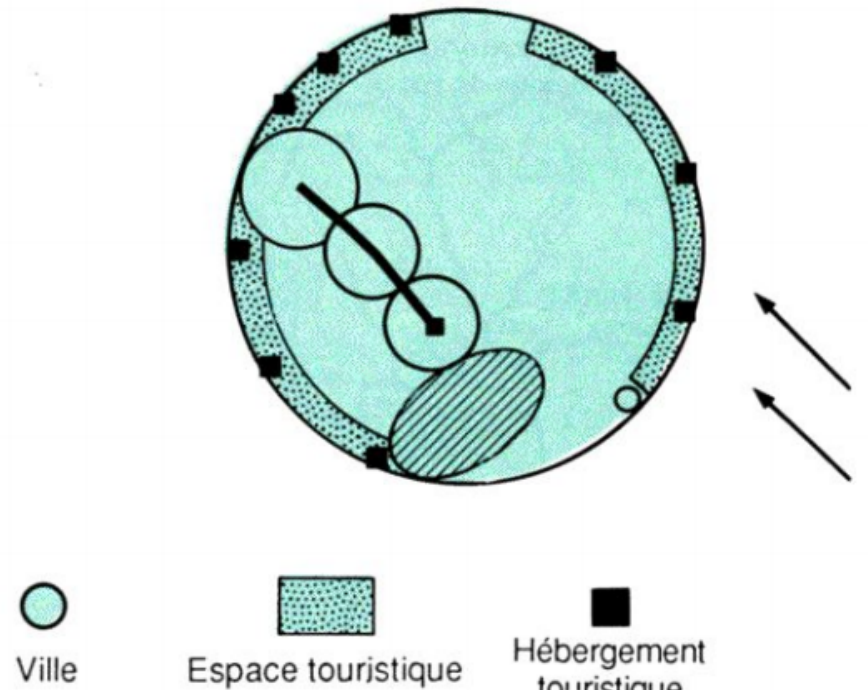

Figura 13. Modelos gráficos comparativos das ilhas de Reunião e Maurício (KNAFOU, 1988) 

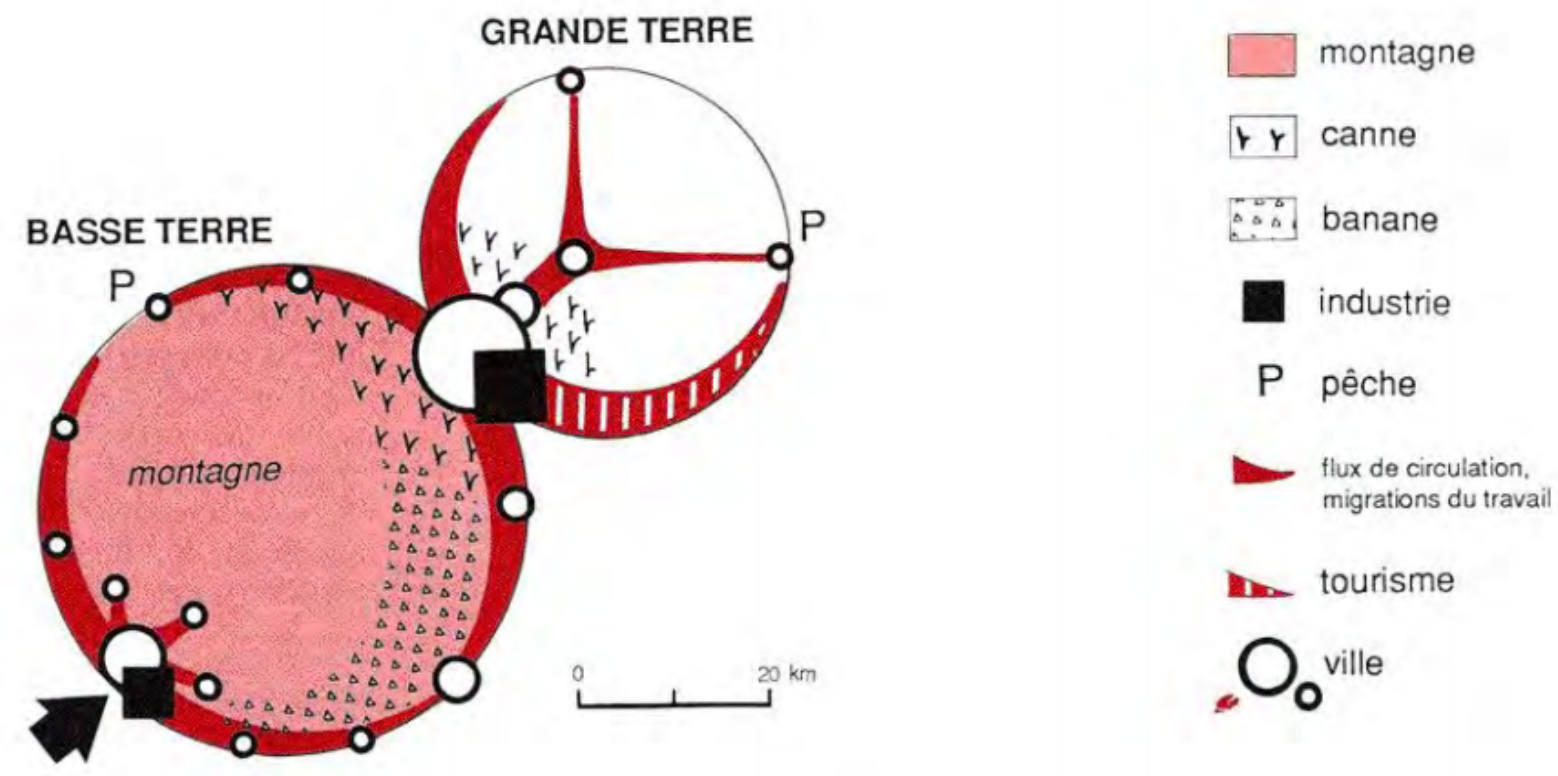

Figura 14. Modelo gráfico da ilha de Guadalupe (BRUNET, 1986)

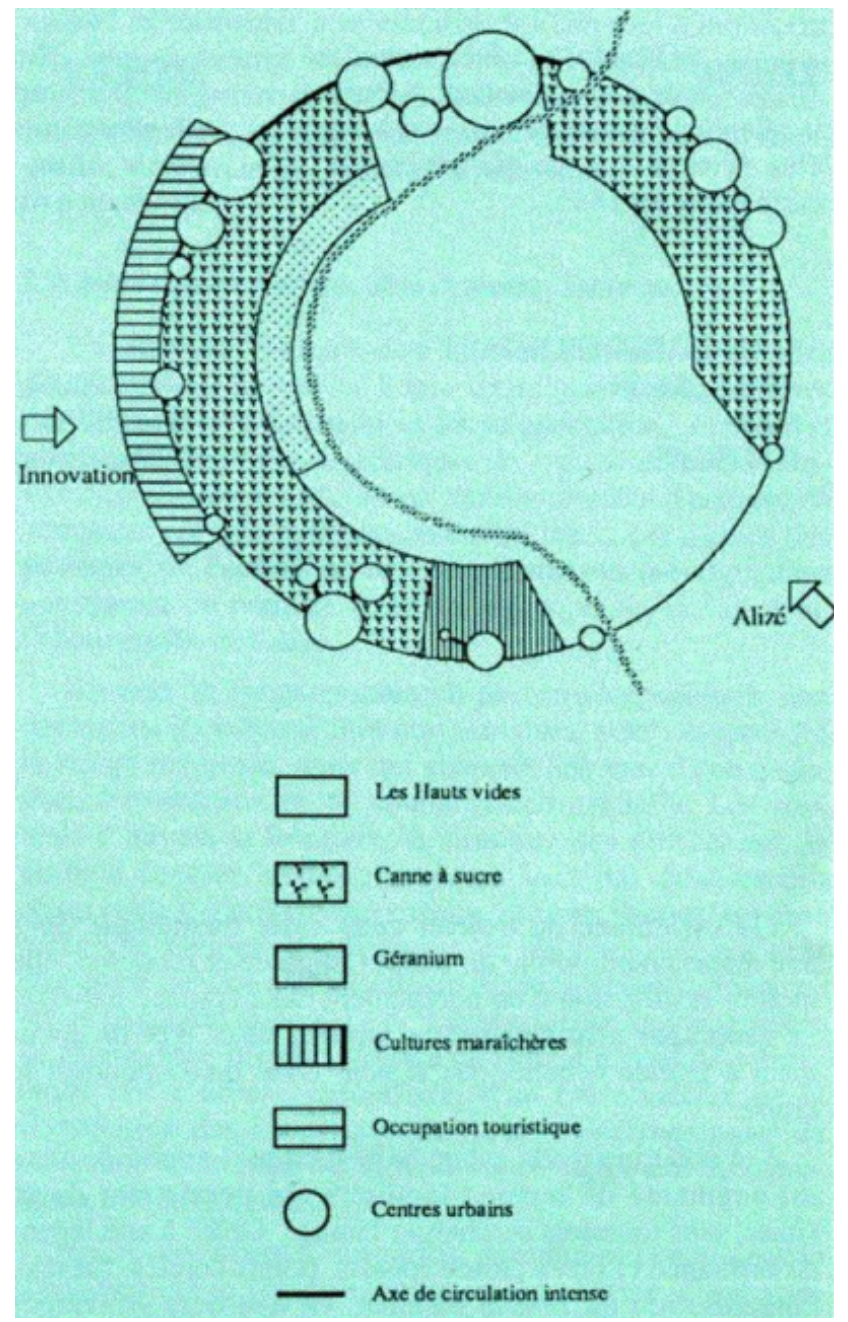

Figura 15. Modelo gráfico da ilha de Reunião (GUÉBOURG e THÉRY, 1988) 


\section{Ubatuba e suas ilhas}

Em nosso contexto pátrio, merece menção o modelo gráfico apresentado por Panizza et al. (2004) para o litoral norte paulista, região dinâmica da atualidade e, por esse caráter, inclusive, objeto de interesse deste trabalho.

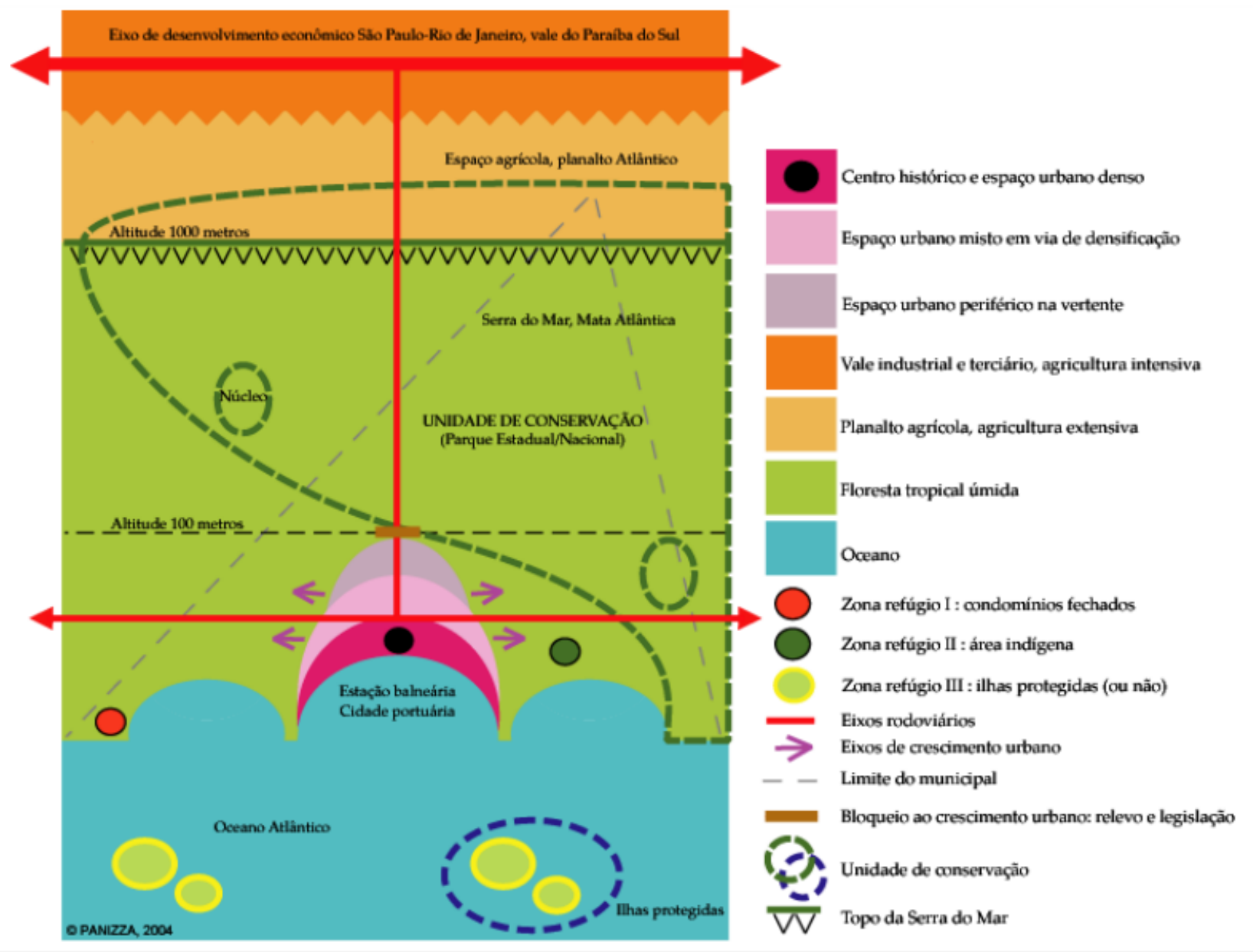

Figura 16. Modelo gráfico de Ubatuba e suas ilhas (PANIZZA et al., 2004) 


\section{B. Corotipos do espaço insular: uma proposta}

\section{Malha}

\subsection{Ponto}

Um ponto destacado assentado ao lado de uma área costeira (com bordas curvas - sejam côncavas, sejam convexas - ou retilíneas, segundo a forma litoral continental) pode indicar uma ilha-capital, sede de uma unidade político-administrativa. Neste caso, a ilha é a própria localidadesede. Em outras escalas, há casos em que a ilha não é encarada como localidade, mas como repositório de localidades, quer na sua costa, quer no seu interior.

\subsubsection{Upaon-Açu (MA)}

Se Vitória (ES) e Florianópolis (SC) também são ilhas-capitais, apenas São Luís (MA) é uma capital estadual inteiramente insular. Situada na ilha Upaon-Açu - topônimo indígena assentido tanto pela tradição como pela Constituição estadual ${ }^{196}$-, é parte do arquipélago do Golfão Maranhense, entre as baías de São Marcos e São José, na foz do rio Mearim, onde abundam reentrâncias estuarinas já densamente ocupados pelos brasilíndios em tempos antecedentes aos da colonização europeia ${ }^{197}$. Que há vantagem no sítio urbano e na situação geográfica de São Luís, é, portanto, algo que espontaneamente se constata ao se examinar a história demográfica e social do litoral nordestino.

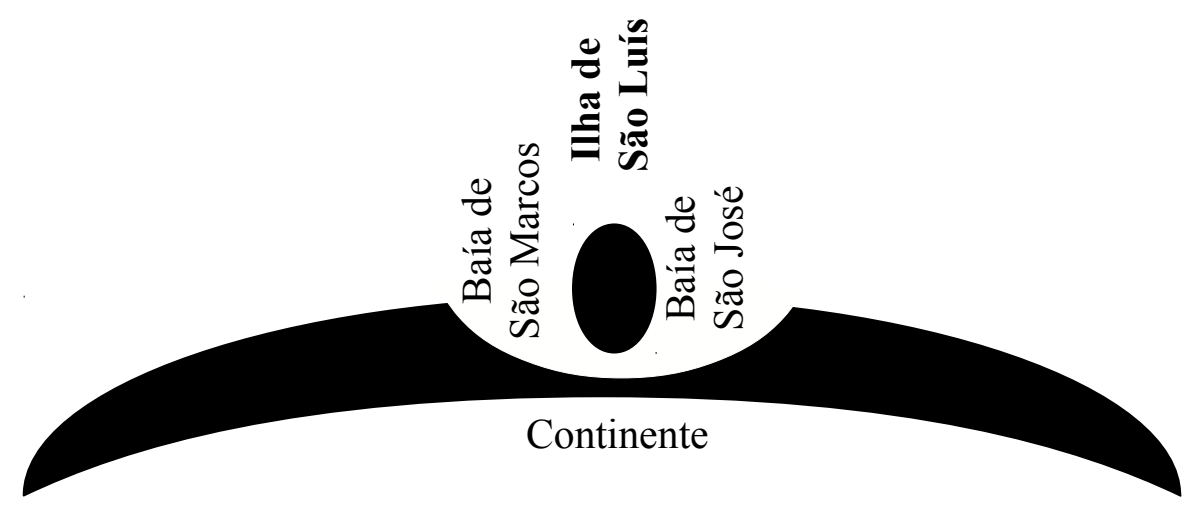

Figura 17. Modelo gráfico da ilha Upaon-Açu (MA) 


\subsubsection{Cuba e Madagascar}

No que tange à localização de uma localidade no espaço insular, reconhecem-se duas situações contrastantes: representadas, em um polo, pela ilha de Cuba, cuja capital e a segunda maior cidade estão assentadas na costa, junto a baías homônimas ${ }^{198}$, e, em outro polo, por Madagascar, cujos altos planaltos centrais alojam Antananarivo, mais importante centro urbano do país $^{199}$.
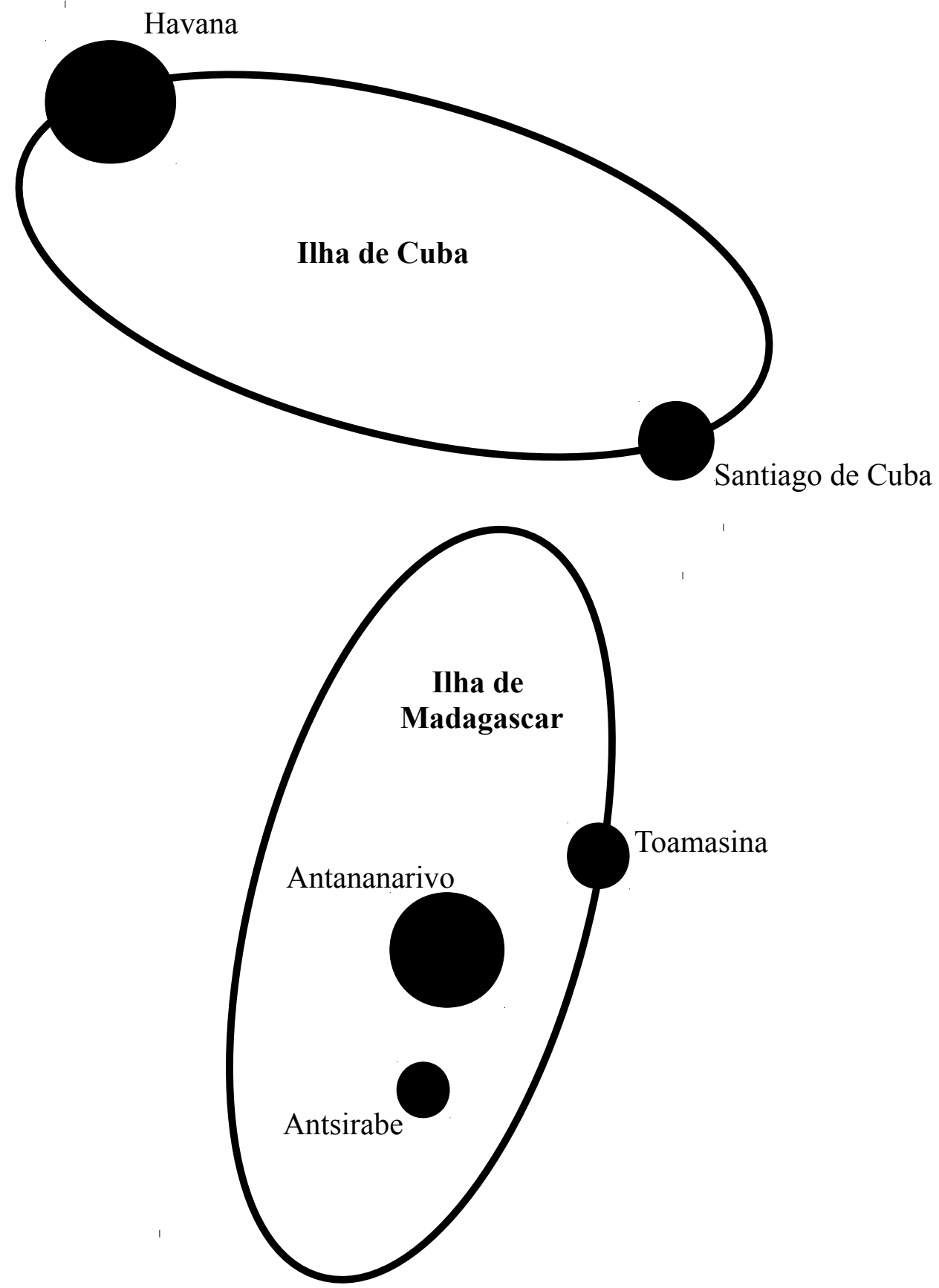

Figura 18. Modelos gráficos das ilhas de Cuba e Madagascar 


\subsection{Linha}

Quando os limites territoriais são tratados em nível intrainsular, pode-se trinchar a ilha (um círculo) lançando mão de linhas fortes, autonomizando, assim, as regiões, províncias, estados, municípios, comunas ou outra sorte de fatias territoriais. Se concebidas na escala interinsular, as linhas devem particularizar as ilhas ou conjuntos de ilhas que formem, por si mesmos, unidades político-administrativas.

\subsubsection{Bornéu}

As secessões de um território alcançam diferentes níveis. No caso de Bornéu, longe de serem acidentes do terreno impressos pela natureza, as fissuras que se assentam sobre o solo na forma de limites administrativos são, em verdade, a materialização de um conjunto de relações de poder que ocorreram naquele espaço com o transpassar dos séculos. Se, em dias atuais, o cisalhamento tripartite confere relevância a uma ilha já notada por sua área, muitos já foram os atores de seu jogo político. Antagonismos e alianças entre coroas autóctones (borneanos e filipinos) e alóctones (espanhóis, portugueses, ingleses e holandeses) desdobraram-se tempo após tempo, desenhando o mapa presente. Com efeito, onde ontem estavam os muçulmanos borneanos, o território neerlandês de Kalimantan e a região setentrional de Sarawak (ao lado da possessão britânica de Sabah) ${ }^{200}$, hoje figuram, respectivamente, o Sultanato de Brunei, cinco das províncias indonésias e dois dos estados malaios.

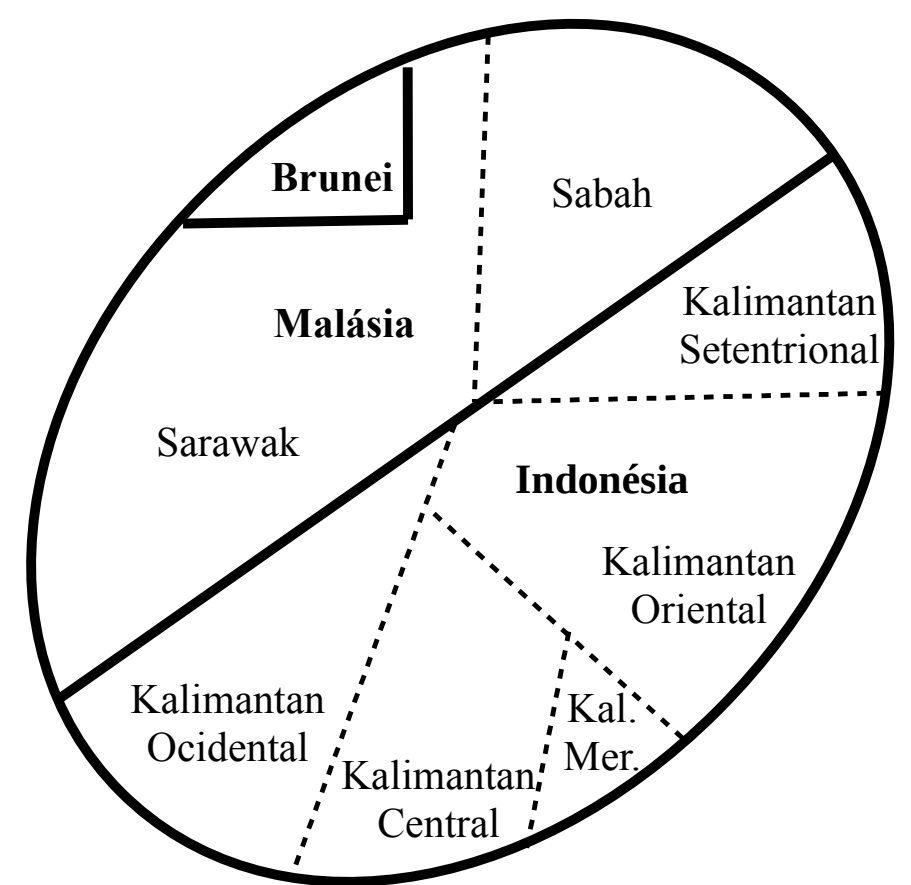

Figura 19. Modelo gráfico de Bornéu

200 LING, 2013, p. 28 


\subsubsection{São Tomé e Príncipe}

Ora, se uma mesma ilha pode ser território de três países, inversamente, está claro, um mesmo país pode ter mais de uma ilha por território. Do ponto de vista físico, São Tomé e Príncipe são duas ilhas. Já do político, são um só país. De mais a mais, se neste caso, da escala nacional, de dois, tira-se um (duas ilhas, um país), numa escala distrital, de um, tira-se seis - seis são as unidades político-administrativas de São Tomé ${ }^{201}$.
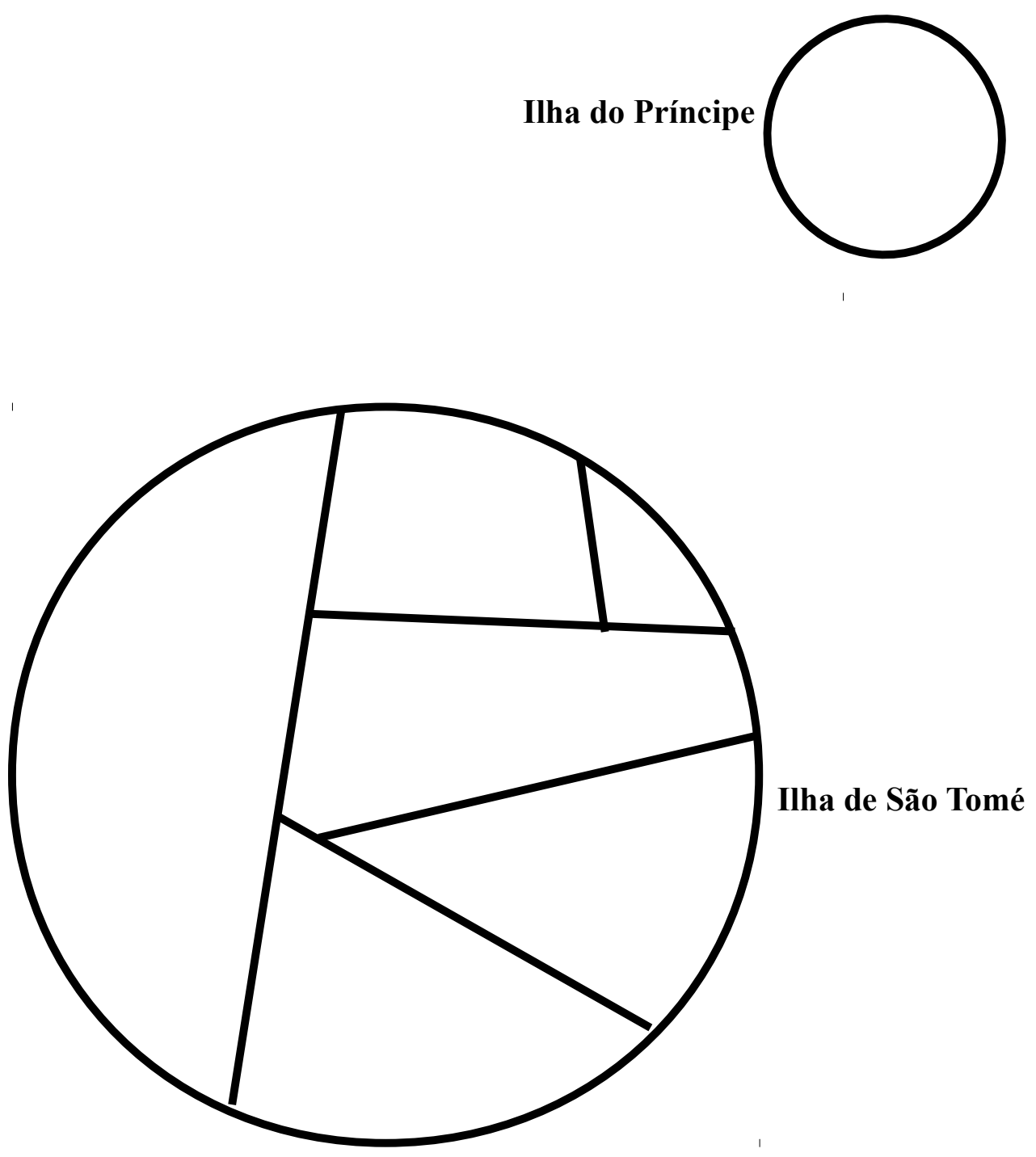

Figura 20. Modelo gráfico de São Tomé e Príncipe

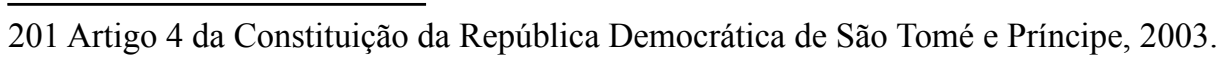




\section{3. Área}

Tomar um círculo ou uma elipse por uma ilha não foi acaso. É o modelo ideal por três motivos. Preliminarmente, pelo fato de a circunferência ser o lugar geométrico de equidistância de todos os pontos a um centro, buscando-se dar a ideia de que o litoral (circunferência) exerce sua influência por todo o interior terral (área do círculo). Insularidade e litoralismo são, pois, conceitos inter-relacionados. Em segundo lugar, devido à curva constante e perfeita da linha circular, o que permite direcionar os pontos da costa para todos os rumos possíveis, vantagem quando se pondera que as ilhas estão ou não inseridas num contexto de rede (tendo em conta que insularidade e isolamento não são conceitos excludentes; muito pelo contrário). Enfim, por ser maleável, tornando-se elipse quando se tiver à mão uma ilha mais anisotrópica, aumentando ou diminuindo de tamanho com facilidade (segundo o poder de influência, a magnitude de um fenômeno, o tamanho físico ou demográfico de dada realidade insular).

Se empregamos um único círculo para um Estado-ilha (uni-insularidade), colocamos à nossa disposição círculos próximos para um Estado-arquipélago (multi-insularidade).

\subsubsection{Nauru e federação micronésia}

Como já examinado, o mar, fronteira e via que é, oferece-se como limite natural e lógico da ilha. Mas as forças históricas estão além. Aproveitam essa condição de diferentes formas, daí implicando uma miríade de possibilidades: uma ilha, um país (Nauru, a menor república do mundo, com $21 \mathrm{~km}^{2}$ ); um país, mais de seiscentas ilhas (Estados Federados da Micronésia) ${ }^{202}$.

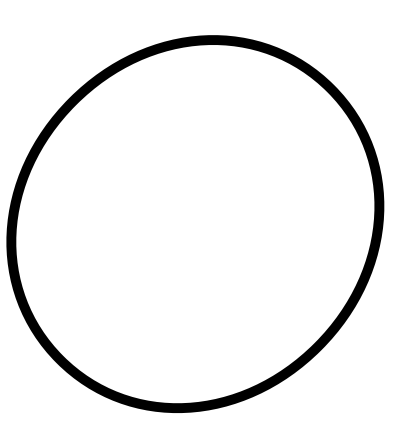

Nauru

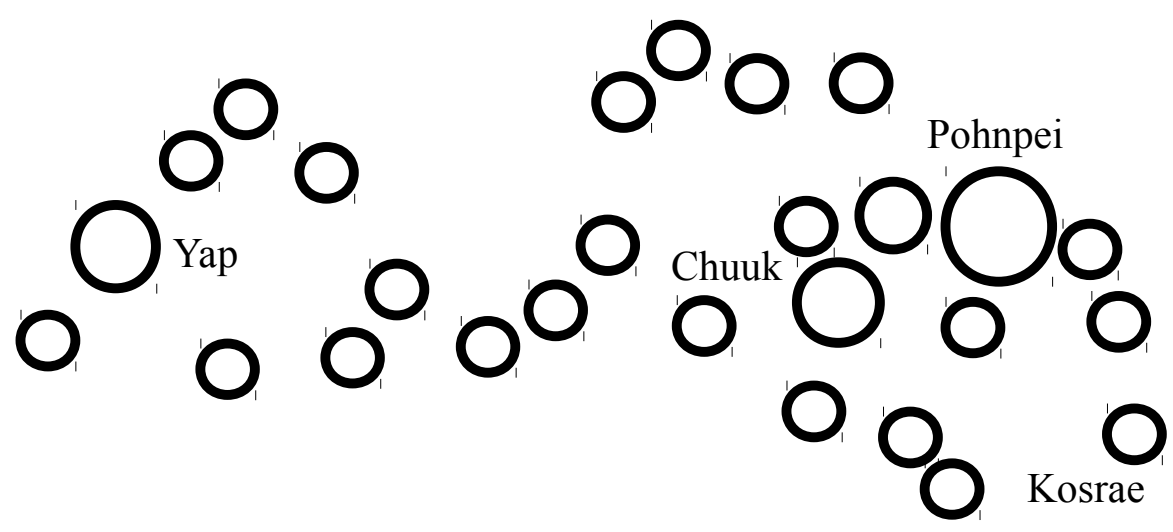

Estados Federados da Micronésia

Figura 21. Modelos gráficos de Nauru e da federação micronésia

202 CIA. The World Factbook. Verbetes acessados: Nauru; Micronesia, Federated States of. 


\subsection{Rede}

Os trezentos e sessenta graus da circunferência permitem que se posicione uma localidade em todos os pontos cardeais, colaterais e sub-colaterais. A localização de cada ponto (localidade) no litoral (circunferência) de cada ilha (círculo ou área de elipse) insinua uma possível ligação interinsular.

\subsubsection{Sociedade (Polinésia Francesa)}

Assim chamadas pelo capitão Cook por "assentarem-se uma contígua à outra" ${ }^{203}$, as ilhas Sociedade dispõem, dada a vantagem comparativa, de um sistema de comunicação que, a despeito do confrangimento marítimo, é capaz de integrar um arquipélago de mais de 200 mil habitantes. Pelos aeródromos próximos à linha costeira, certa proximidade e disposição de cada ilha no desenho arquipelágico, é possível averiguar no mapa da Polinésia Francesa que se, individualmente, uma ilha pode contar com uma distribuição particular de centros urbanos, a forma do conjunto de ilhas e a localização de cada centro insinuam uma comunicação interinsular. Avista-se com mais facilidade esse fato quando as ilhas eleitas para tal exame de observação são, no conjunto do barlavento, Taiti e Moorea, e, no do sotavento, Raiatea e Tahaa.

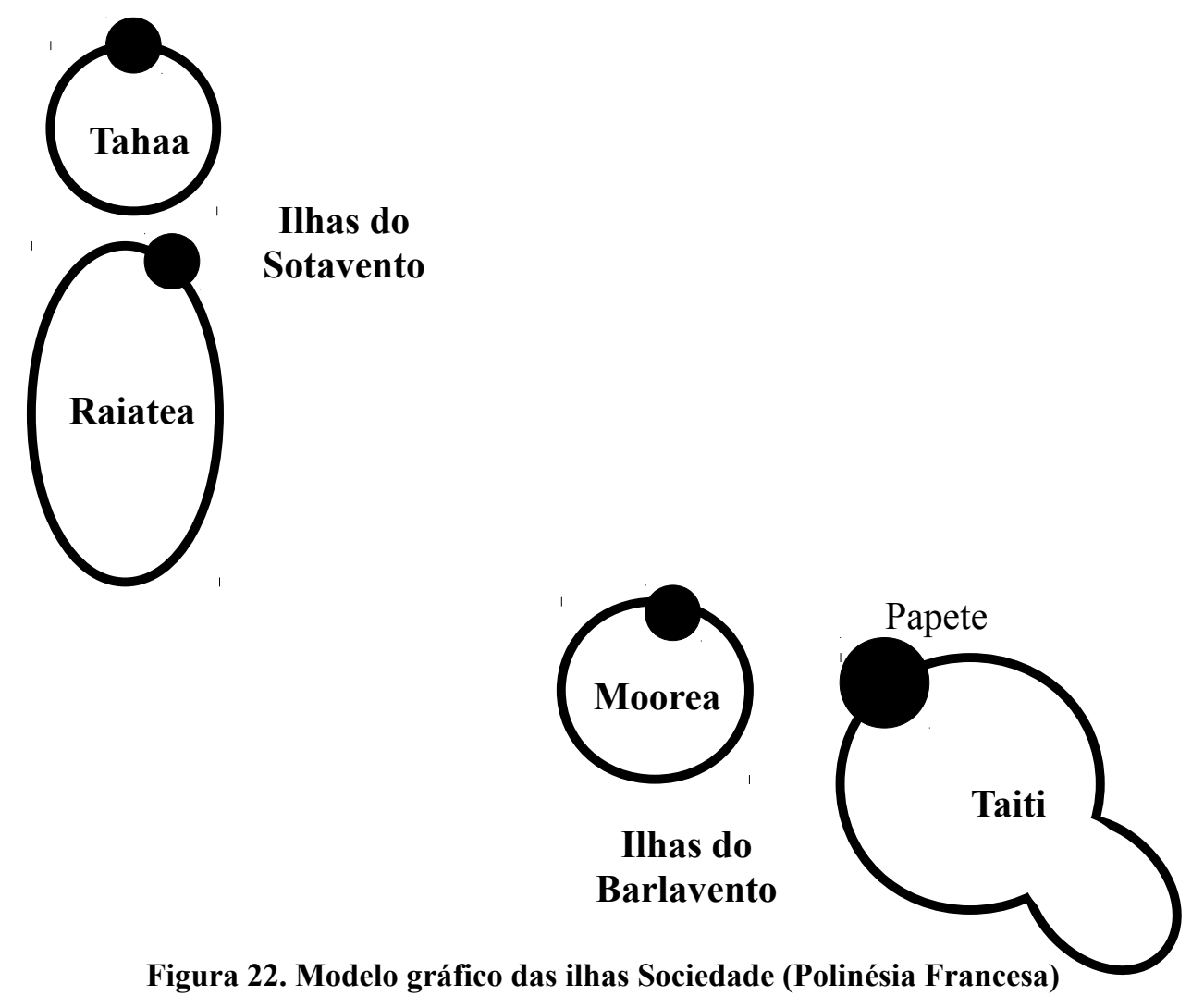

203 HORWITZ, 2003, p. 42 


\section{Disposição}

\subsection{Ponto}

A configuração ou disposição pode ser um dado do conjunto de ilhas ou de uma ilha em isolado. No primeiro contexto, as ilhas serão como pontos ou pequenos círculos, podendo formar, em grupo, linhas retas (lineamentos), linhas curvas (arco insular) ou concentrações não regulares (aglomerados). No segundo, a combinação com outros elementos gráficos permite representar categorias insulares específicas: se muito excêntrica a elipse e se próxima de região costeira, isolando um delgado retângulo azul (água), pode significar ilha barreira, ao passo que, quando abrigar outro círculo interior (laguna), pode oferecer-se como atol. As linhas de costa, de sua parte, recebem curvas à proporção de suas articulações (salientes ou reentrantes) e adquirem pontos de densidade segundo os graus de concentração ou distribuição da população.

\subsubsection{Havaí, Canárias e Santa Helena}

Quanto à forma física em que um conjunto de ilhas está disposto, as variações são sempre pertinentes, já porque podem influenciar na relação interinsular, já porque prenunciam alguns encalços de sua gênese. Profícuo é o caso das ilhas intraplacas, derivadas de pontos quentes (hotspots), uma vez que diversas são as possibilidades de disposição arquipelágica dele decorrentes, a saber, lineamento, como o Havaí, aglomerado, como as Canárias, e ilha isolada, como Santa Helena $^{204}$ - a primeira no oceano e na placa tectônica do Pacífico, as duas últimas no oceano Atlântico e na placa africana.

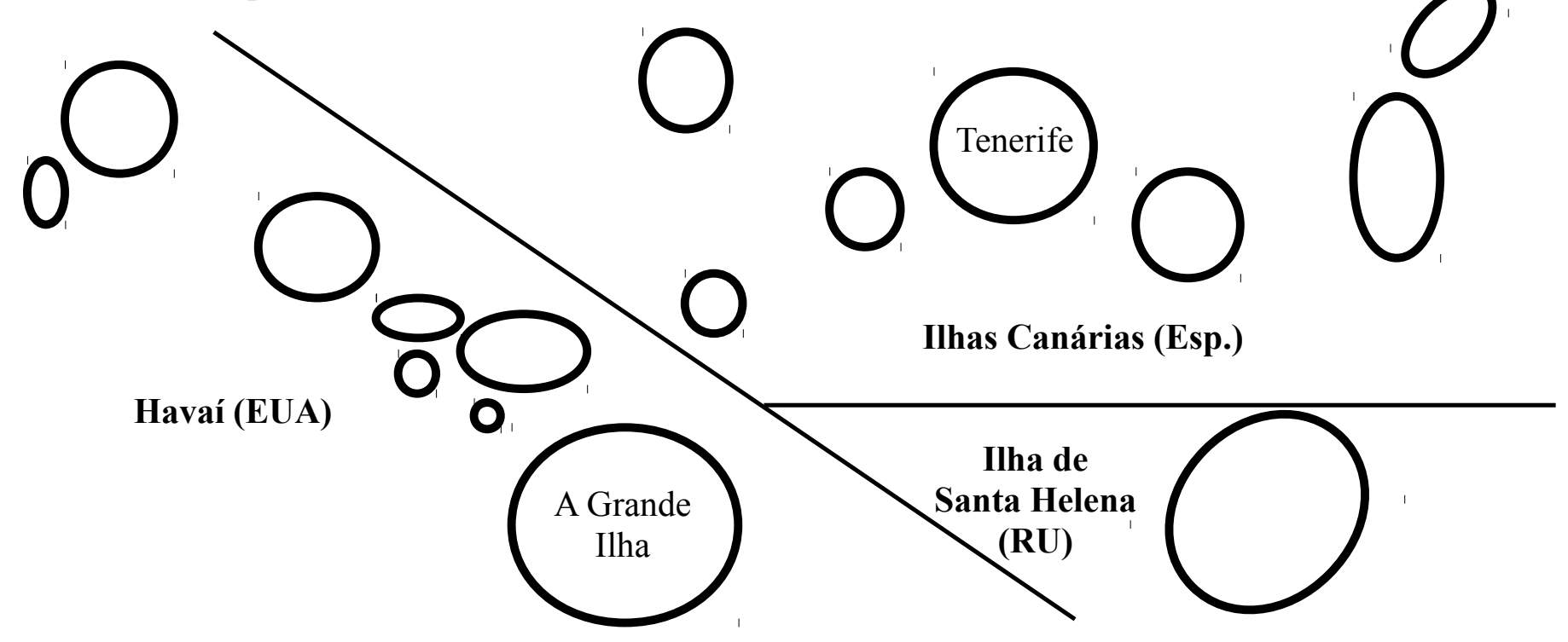

Figura 23. Modelos gráficos do Havaí, das Canárias e da ilha de Santa Helena

204 NUNN, 1994 apud WHITTAKER e FERNÁNDEZ-PALACIOS, Op. cit., p. 19 


\subsubsection{Iha Comprida (município, SP) e Funafuti (Tuvalu)}

Para as ilhas sedimentares, a forma é igualmente importante, desvelando, numa só tomada, algo sobre sua geologia e o tipo de relações sociais que pode ensejar. De um lado, uma ilha barreira a exemplo da Ilha Comprida, cuja alta razão comprimento/largura - provinda dos processos de deposição arenosa marinha e areno-argilosa flúvio-estuarina e flúvio-lagunar ${ }^{205}$ - constrange o acesso entre povoações intrainsulares e, concomitantemente, oportuniza a transposição do interior terral em direção à costa a sotavento, apartada de Cananeia e Iguape senão pela delgada faixa de águas abrigadas do mar Pequeno. De outro lado, na face oposta da Terra, em plena Polinésia, a capital de Tuvalu é uma realidade geográfica ambígua: um único atol em contexto regional, algo em torno de trinta ilhotas numa investigação mais localizada. Para a questão, "onde está a sede do governo tuvaluano?”, há, pois, duas respostas possíveis: “o atol de Funafuti”, arriscarão os mais práticos, "a localidade de Vaiaku, em Fongafale, a maior das ilhotas de Funafuti"206, dirão categoricamente os mais detalhistas. Isso porque, como é de praxe nas lições de Geografia, olhar ilhas é também olhar escalas.

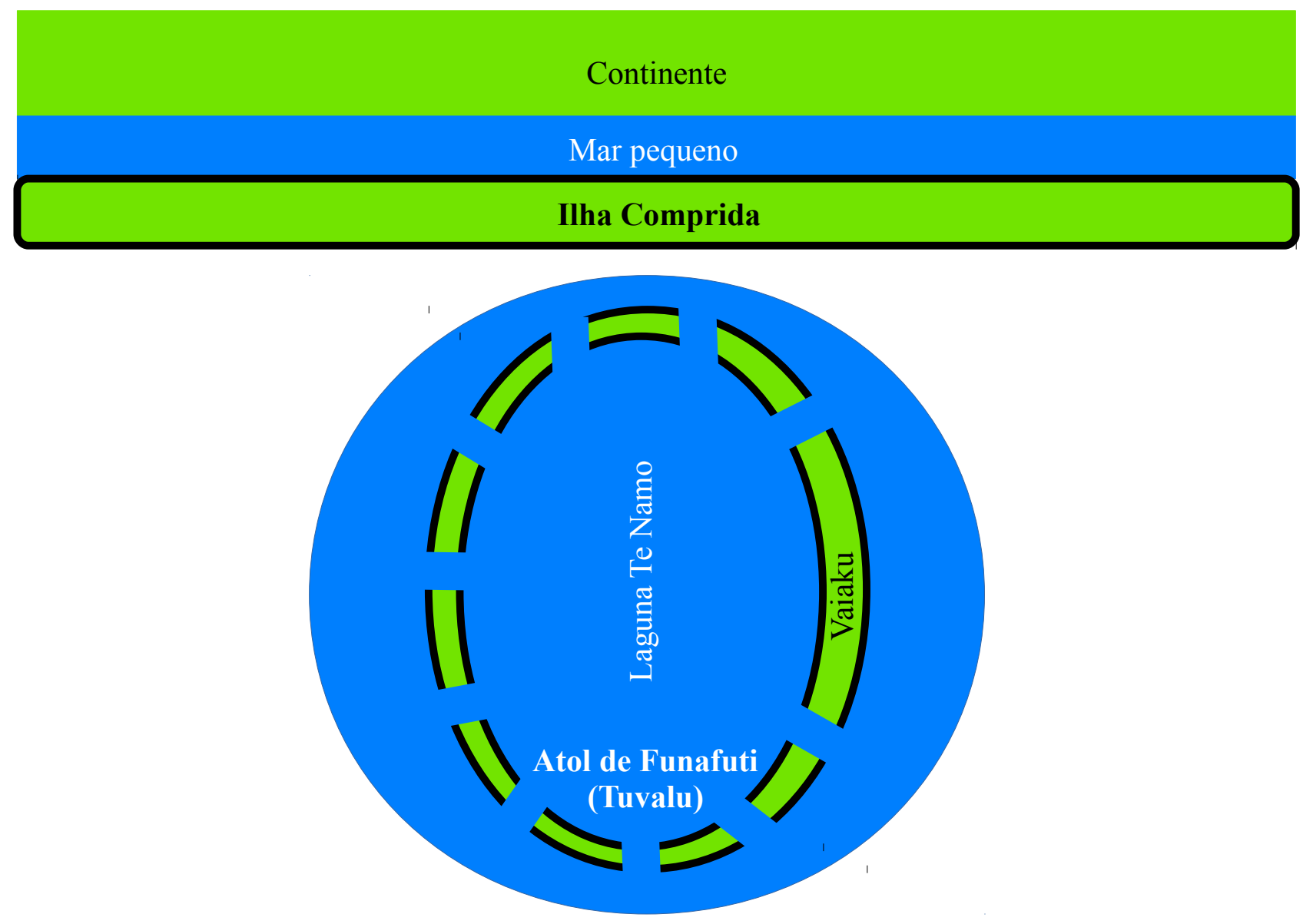

Figura 24. Modelos gráficos da Ilha Comprida (município, SP) e de Funafuti (Tuvalu)

205 SUGUIO e MARTIN (1994) apud GUEDES, 2009, p. 9

206 CIA. The World Factbook. Verbete consultado: Tuvalu. 


\subsubsection{Páscoa e Islândia}

Acerca dos tipos de costa, contrasta-se a Islândia, plataforma giratória de altas latitudes do Atlântico notabilizada por Júlio Verne, à ilha de Páscoa, um triângulo retângulo do Pacífico, pouco ao sul do trópico de Capricórnio, que, pela curiosa biodiversidade, despertou o interesse de Charles Darwin. Isso porque a costa articulada da Islândia é tipicamente de condensação, convidativa ao povoamento e muito bem integrada por famigerada estrada anelar ${ }^{207}$, ao passo que o litoral de Páscoa é comparativamente mais retilíneo, com população dispersa e exígua, com exclusão da reentrância onde se assenta Hanga Roa, que retém mais de quatro quintos dos insulares ${ }^{208}$.

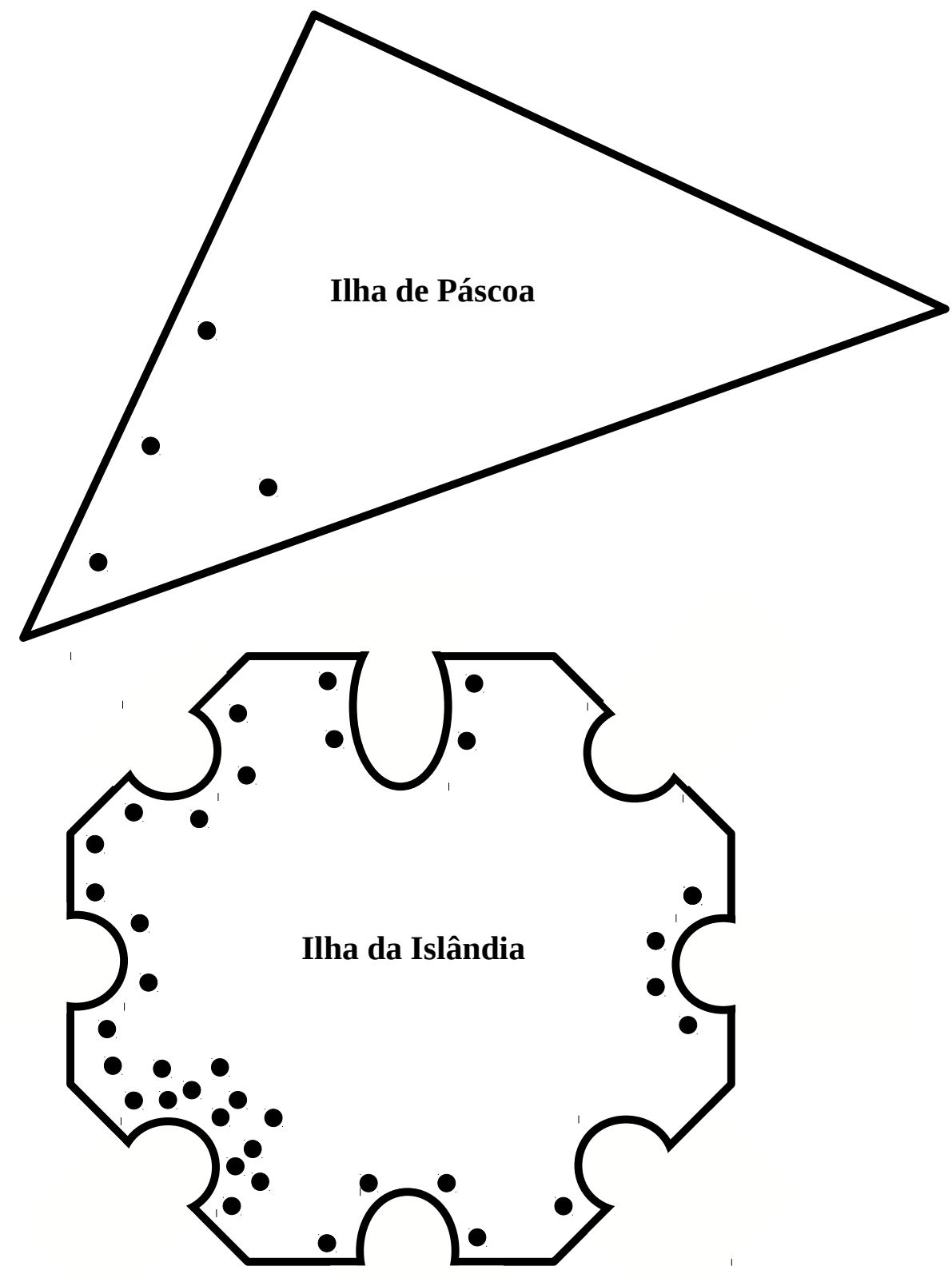

Figura 25. Modelos gráficos das ilhas de Páscoa e da Islândia

207 Informações sobre a Estrada Anelar disponíveis no sítio eletrônico da Administração Viária e Costeira da Islândia: $<$ http://www.road.is/>.

208 Para mais estatísticas, acessar o sítio eletrônico do Instituto Nacional de Estatísticas do Chile: $<$ http://www.ine.cl/>. 


\subsection{Linha}

Linhas curvas ou retilíneas atando pontos dispersos do círculo (ilha) serão suas ligações internas, quer redes de drenagem, quer vias de circulação.

\subsubsection{Marajó (PA) e Santiago (Cabo Verde)}

Em Santiago, a integração do território dá-se por intermédio de ligações internas, ora disponibilizadas pela natureza, ora fruto de façanha humana. Cabo Verde, na faixa do Sahel, por não dispor de rede hidrográfica perene facilitadora de itinerários, reclama, num contexto de modernização infraestrutural experimentada recentemente, um sistema viário robusto que possa integrar os centros urbanos e escoar as mercadorias. Com uma densidade rodoviária de 3,5 km de estradas $/ \mathrm{km}^{2}$ de terra arável - relativamente alta se comparada a outros países insulares de patamar socioeconômico semelhante e maior condensação nas ilhas de Santiago, Boa Vista e Santo Antão ${ }^{209}$ -, uma miríade de benfeitorias é imperiosa, como, a título de exemplo, restauros na pista de rolamento que conecta Tarrafal, Assomada e Praia, a capital nacional.

Já na maior ilha fluviomarinha do mundo, Marajó, no Pará, a rede hidrográfica é fator de integração, quer do interior insular, quer do arquipélago homônimo, que, de seu partido, compreende 16 municípios distribuídos por mais de 100 mil km²10.
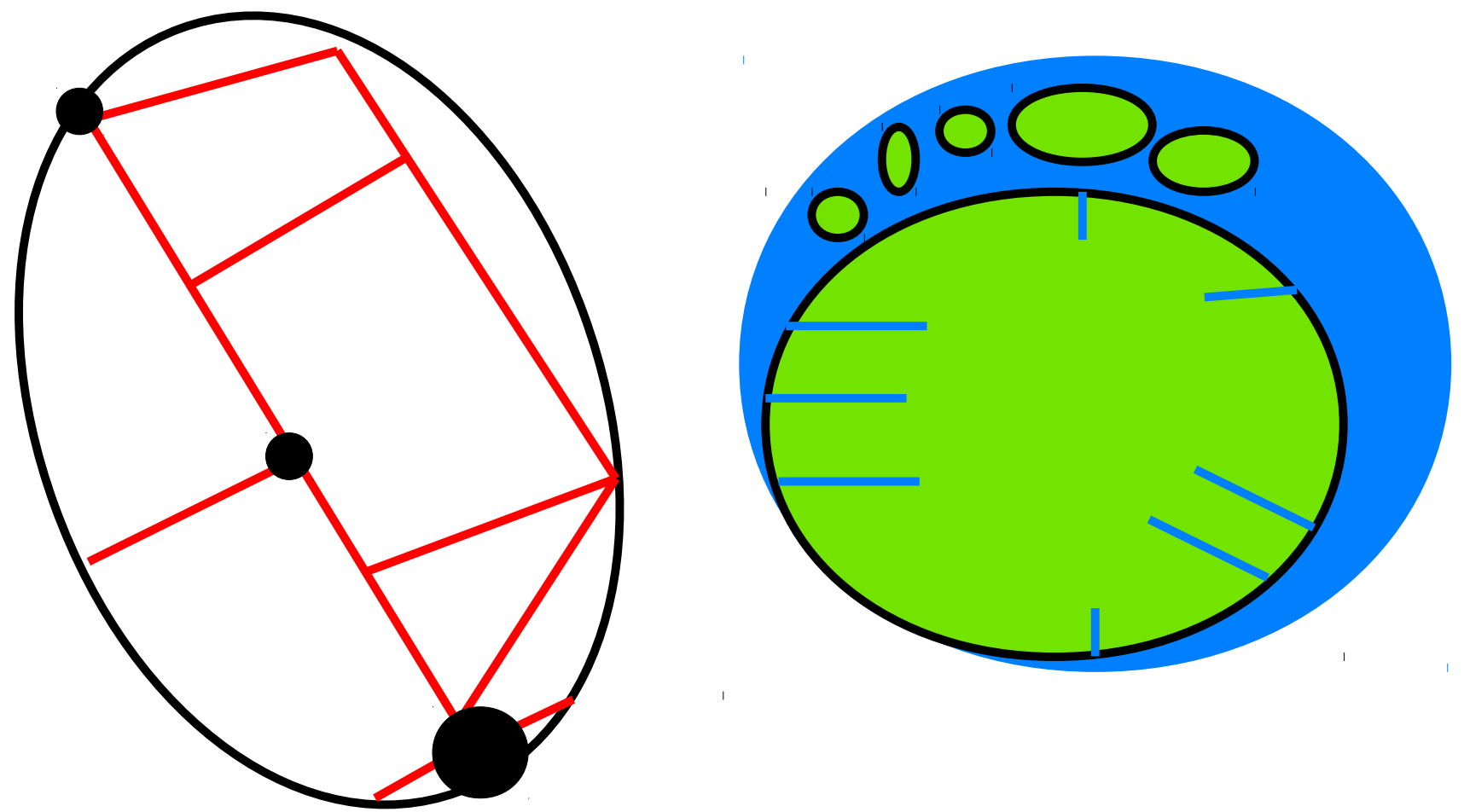

Figura 26. Modelos gráficos das ilhas de Santiago (Cabo Verde) e Marajó (PA)

209 BRICEÑO-GARMENDIA e BENITEZ, 2010, p. 10

210 Para mais informações, acesse o Portal “Cidades”, do IBGE: <https://cidades.ibge.gov.br/xtras/home.php?lang=>. 


\section{3. Área}

Compartimentos dentro de um círculo diferenciáveis por variáveis visuais de separação (cores, hachuras orientadas) dão ideia de classificação regional, sejam regiões sintéticas (fenômenos combinados), sejam analíticas (um só critério).

\subsubsection{Ilha de São Sebastião (SP)}

Um olhar atento às isoietas ${ }^{211}$ permite discriminar diferenças pluviométricas mais ou menos pronunciadas no interior da ilha de São Sebastião (onde se assenta a sede municipal de Ilhabela). Essa regionalização topoclimática em ambientes advém da barreira orográfica do setor a barlavento para os fluxos atmosféricos úmidos dominantes de sudeste ${ }^{212}$. Ventos ascendentes na vertente voltada ao oceano contrastarão, portanto, com o escoamento descendente quente e seco na vertente voltada ao continente. Não se trata de outro efeito senão de uma sombra de chuva.

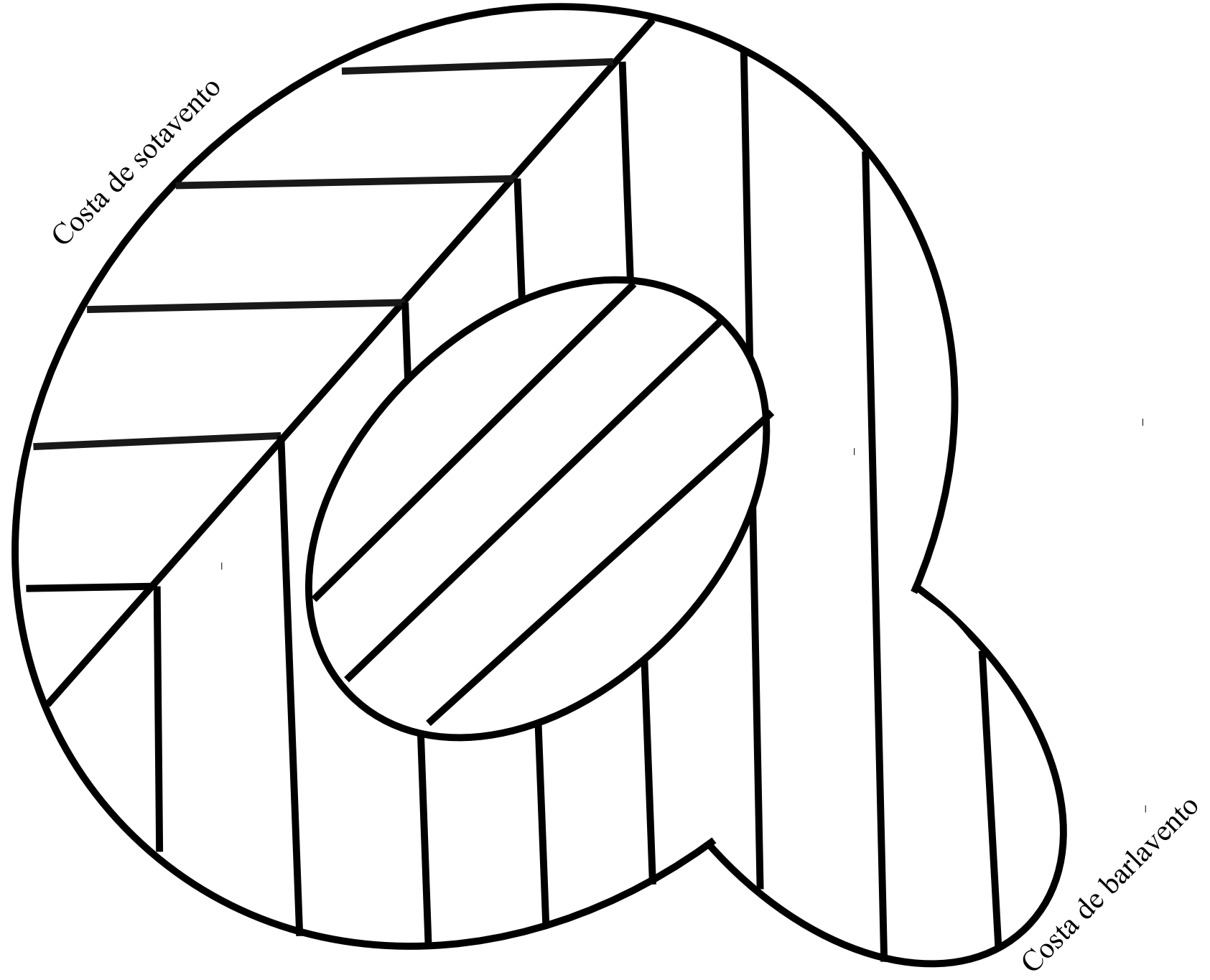

Figura 27. Modelo gráfico da Ilha de São Sebastião (SP)

211 MILANESI, 2007, p. 35

212 Ibidem, p. 46 


\subsection{Rede}

$\mathrm{Na}$ teoria dos grafos ${ }^{213}$, da lógica espacial topológica, os pontos são nós, as linhas que os interconectam são arcos. Precisamente, para ponto, leia-se ilha; para linhas, leia-se rede. Por conseguinte, para ponto atravessado por linha, entenda-se ilha nodal de rede de comunicação e circulação; para ponto sem linha próxima (de outra cor, se possível, para destacar e diferenciar), perceba logo uma ilha isolada, quer pelo acaso, quer por uma razão.

\subsubsection{Hong Kong e Tristão da Cunha}

Se exequível fosse elaborar uma escala de medida para o grau de integração de uma ilha às redes mundiais de circulação náutica e aeronáutica, em uma extremidade, ter-se-ia, Hong Kong, e, em outra, Tristão da Cunha. Em verdade, as vantagens locacionais da primeira em relação à segunda não se dão somente pelo fato de ela ter fluxos regulares a outras ilhas e ao continente, mas também pela proximidade natural com essas realidades - em, especial com a China -, enquanto, no caso de Tristão, a menor regularidade de deslocamentos pactua-se com a condição de ser a ilha habitada mais remota do mundo (dois mil quilômetros a Santa Helena ${ }^{214}$, a localidade mais próxima, já isolada, que abrigou Napoleão depois dos Cem Dias). Ora, se Tristão da Cunha é ilha por excelência (exemplo de superinsularidade), Hong Kong apenas o é em sentido absoluto, pois, como expõe Kluge ${ }^{215}$, sua insularidade já estaria descaracterizada (caso de hipoinsularidade ${ }^{216}$ ).

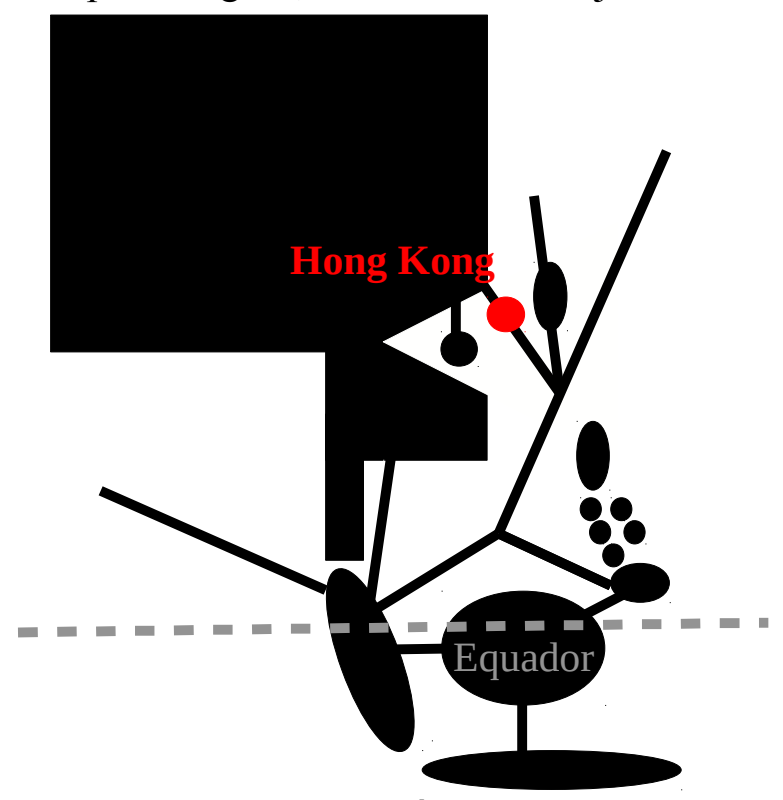

No Sudeste Asiático Redes de circulação

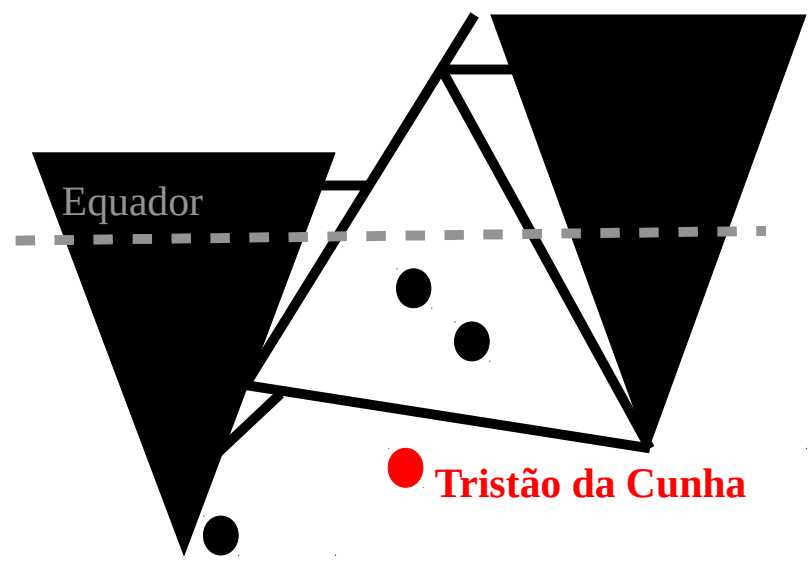

No Atlântico Sul

Figura 28. Modelos gráficos de Hong Kong e Tristão da Cunha

213 HAYES, 2000

214 CIA. The World Factbook. Verbete consultado: Saint Helena, Ascencion and Tristan da Cunha.

215 KLUGE, loc. cit.

216 THIERRY, loc. cit. 


\section{Gravitação}

\subsection{Ponto}

Setas direcionais e uma cor de destaque para a ilha central podem indicam relação centroperiferia. É a gravitação sob o modo de implantação pontual.

\subsubsection{Maurício}

Tal qual sustentou Brunet ${ }^{217}$, o espaçamento e a gravidade constituem duas forças motrizes da realidade geográfica. É, pois, com elas que os objetos e os fenômenos adquirem relação e localização. Precisamente, as ilhas Maurício, no sudeste africano, bem incorporam certas relações de poder e hierarquia, típicas de todo o território, em que centro e periferia, dominação e subordinação, polo influenciador e zona influenciada amanham seus contornos no mapa. A valer, Maurício é a principal terra emersa do arquipélago das Mascarenhas Orientais, assenhorando-se das ilhas Agalega, Rodrigues e São Brandão ${ }^{218}$, todas elas constituindo um único país.

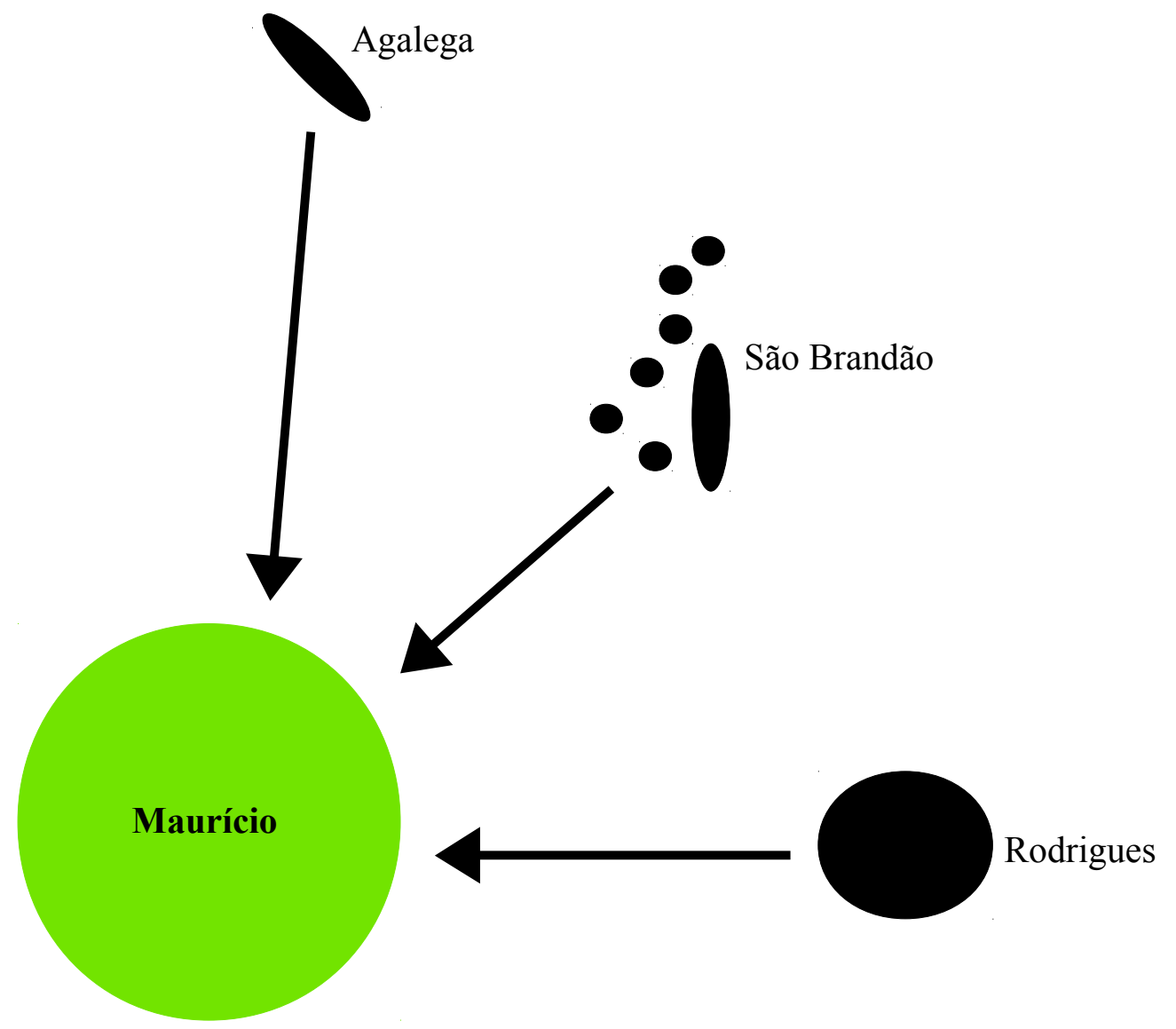

Figura 29. Modelo gráfico das ilhas Maurício 


\subsection{Linha}

Se o centro geométrico do modelo gráfico coincidir com o centro geográfico, tanto melhor, pois o foco deve recair primeiro sobre o elemento capital, depois sobre os demais, que ocuparão áreas marginais segundo seu grau de atração gravitacional à área principal. A ideia mister aqui, contudo, é marcar o espaço disponível para o desenho com auréolas ou quadrados de diferentes tamanhos, mais ou menos concêntricos, de modo a esquematizar a intensidade do campo gravitacional conforme a distância. Conceba-se a distância, é lógico, num sentido relativo.

\subsubsection{Florianópolis (SC), Fernando de Noronha (PE) e Ilha do Sul (Martim Vaz, Vitória, ES)}

O Brasil, país genuinamente atlântico, detém ilhas em distintos níveis de isolamento, seja pelas ligações que estabelecem com a sede continental, seja pela distância à linha de costa. Liste-se em ordem de disjunção (do menor para o maior grau) três exemplos da nossa realidade nacional e ter-se-á Florianópolis (ilha-capital, apartada do continente senão por estreita faixa aquática), Fernando de Noronha (distrito estadual de Pernambuco, situa-se a $500 \mathrm{~km}$ da capital do estado, Recife) e Ilha do Sul (no arquipélago de Martim Vaz, a $28^{\circ}$ 51' O, a mais de $1.000 \mathrm{~km}$ de Vitória, município ao qual, do ponto de vista político-administrativo, está ligada, é o ponto mais oriental do

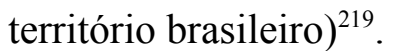

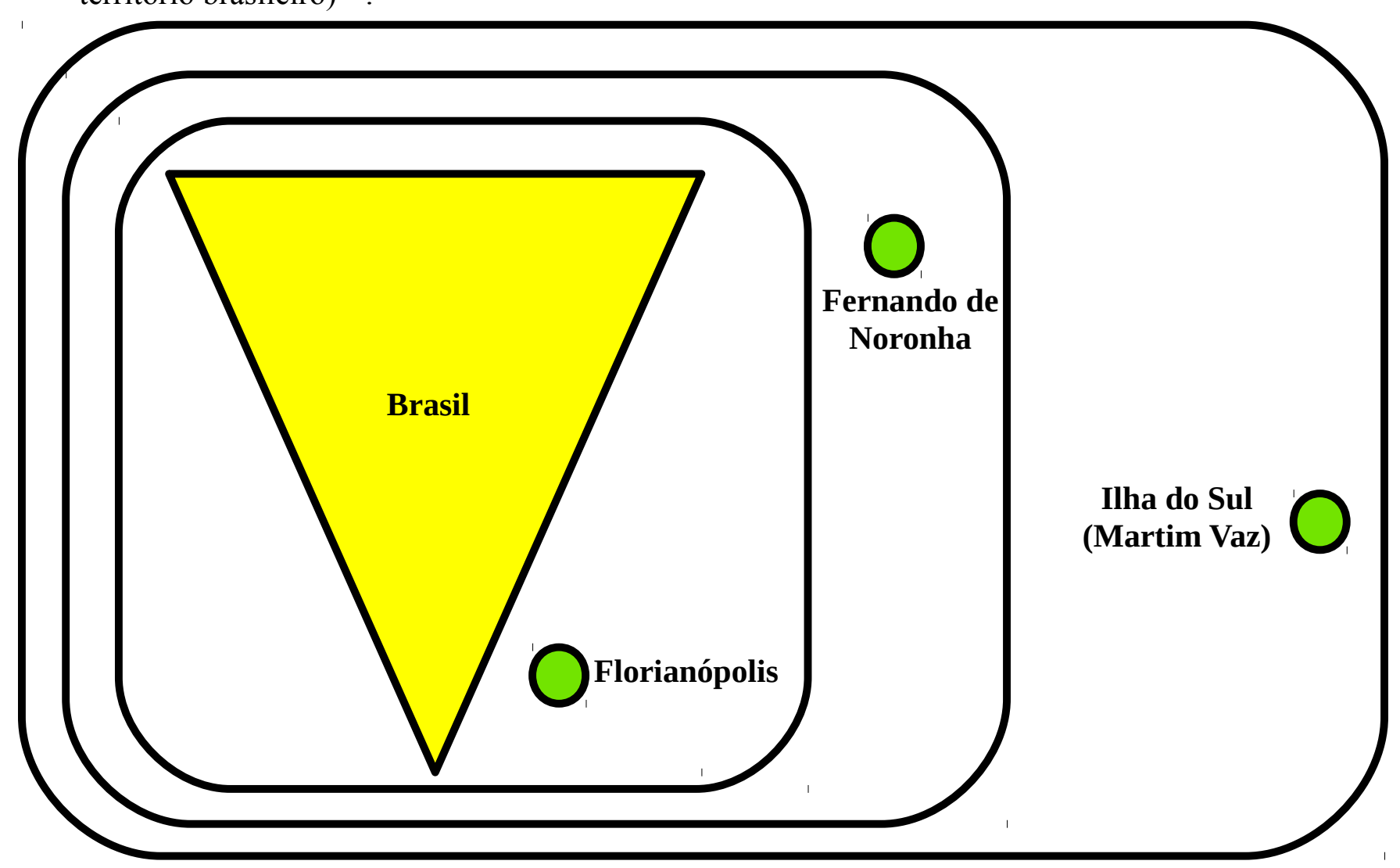

Figura 30. Modelos gráficos de Florianópolis, Fernando de Noronha e Ilha do Sul (Martim Vaz)

219 IBGE e MB, 2011, p. 34-35 


\section{3. Área}

Se as auréolas estiverem representando o interior insular e se empregadas na forma de faixas de mesma cor com variação ordenada de valor ou de bandas de cores diferentes com gradação que permita o estabelecimento de uma ordem, estar-se-á diante de níveis de afastamento do litoral ou do interior terral, de modo a explorar conceitos como maritimidade.

\subsubsection{Santo Antão (Cabo Verde)}

Uma íntima associação entre altimetria e níveis de umidade e precipitação é reconhecível nos mapas topoclimáticos do arquipélago de Cabo Verde ${ }^{220}$. Apesar de estar na faixa do Sahel, o espaço cabo-verdiano abriga realidades como Santo Antão, cujos andares altimétrico-climáticos variam do rés árido ao pico úmido, dada a configuração do relevo, os nevoeiros, as correntes úmidas ascendentes e as altitudes mais ou menos pronunciadas típicas da gênese insular vulcânica.

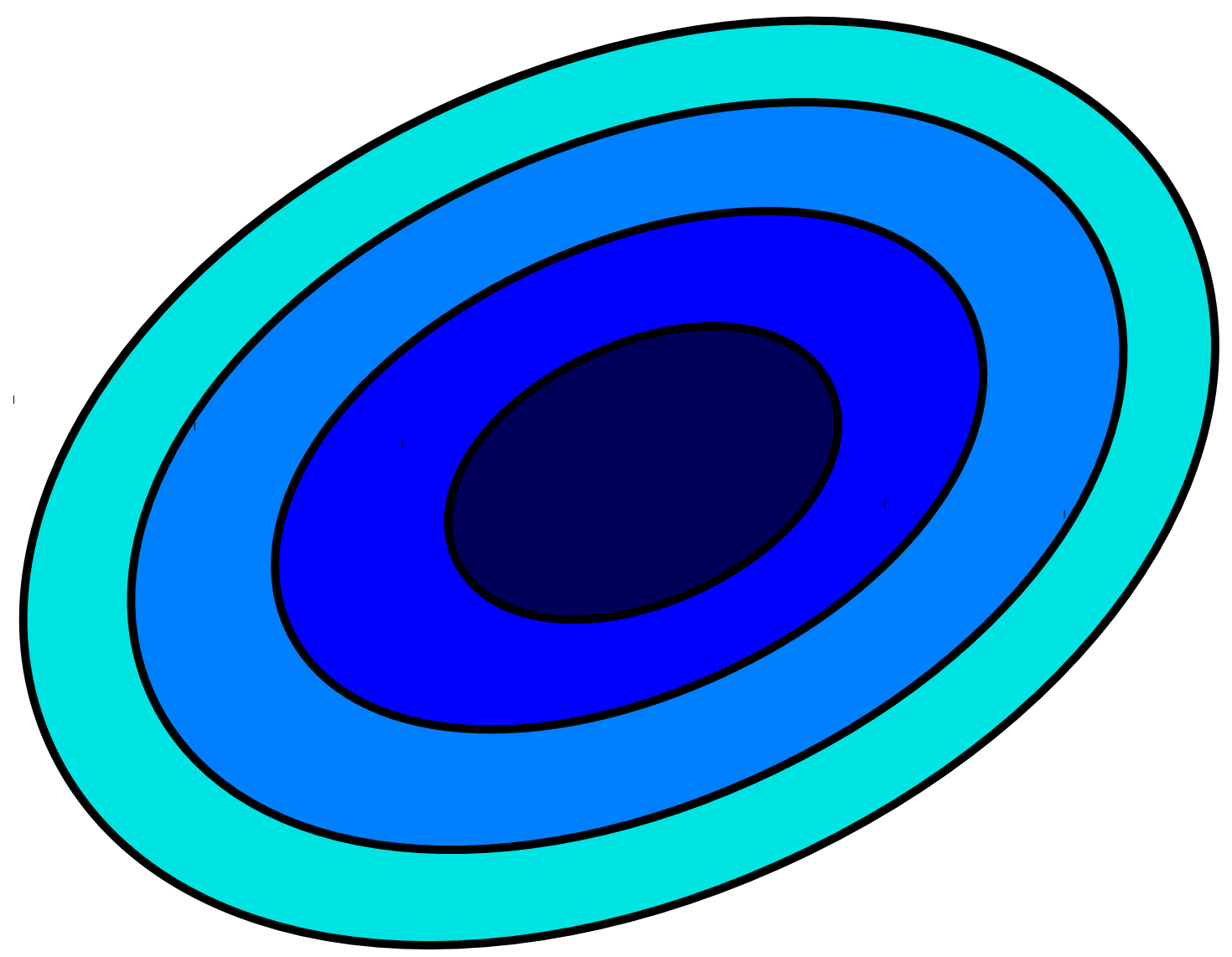

Figura 31. Modelo gráfico da ilha de Santo Antão (Cabo Verde)

220 CARDOSO, 2006, p 21 


\subsection{Rede}

Espécie de auras azuis em redor dos círculos (ilhas), os mares constituem o par necessário para compor com a terra a condição insular. Água e terra em unidade: eis a insularidade. Se acrescentarmos linhas radiais a essas terras, interconectando-as pelos mares, teremos, por resultado, as ligações preferenciais de um arquipélago, traço essencial da lógica gravitacional que se desenvolve em seu âmago.

\subsubsection{Japão}

Nos seus estudos sobre o Japão, Pelletier ${ }^{221}$ arrazoou que a insularidade se manifesta não unicamente pela distância, porém (e sobretudo) pelo espaço de contato. Por certo, esse país, potência mundial hoje, mundo feudal ontem, tem no mar a base para as relações espaciais cinzeladas em sua história milenar. A sério, uma robusta rede interconectora foi esculpida no arquipélago, sobretudo entre Hokkaido, Honshu, Shikoku e Kyushu, por meio das baías de Tóquio e Osaka, do mar do Japão, do canal Bungo, dos estreitos Kii-suido e Tsugaru e dos nadas ou mares intestinos ${ }^{222}$.

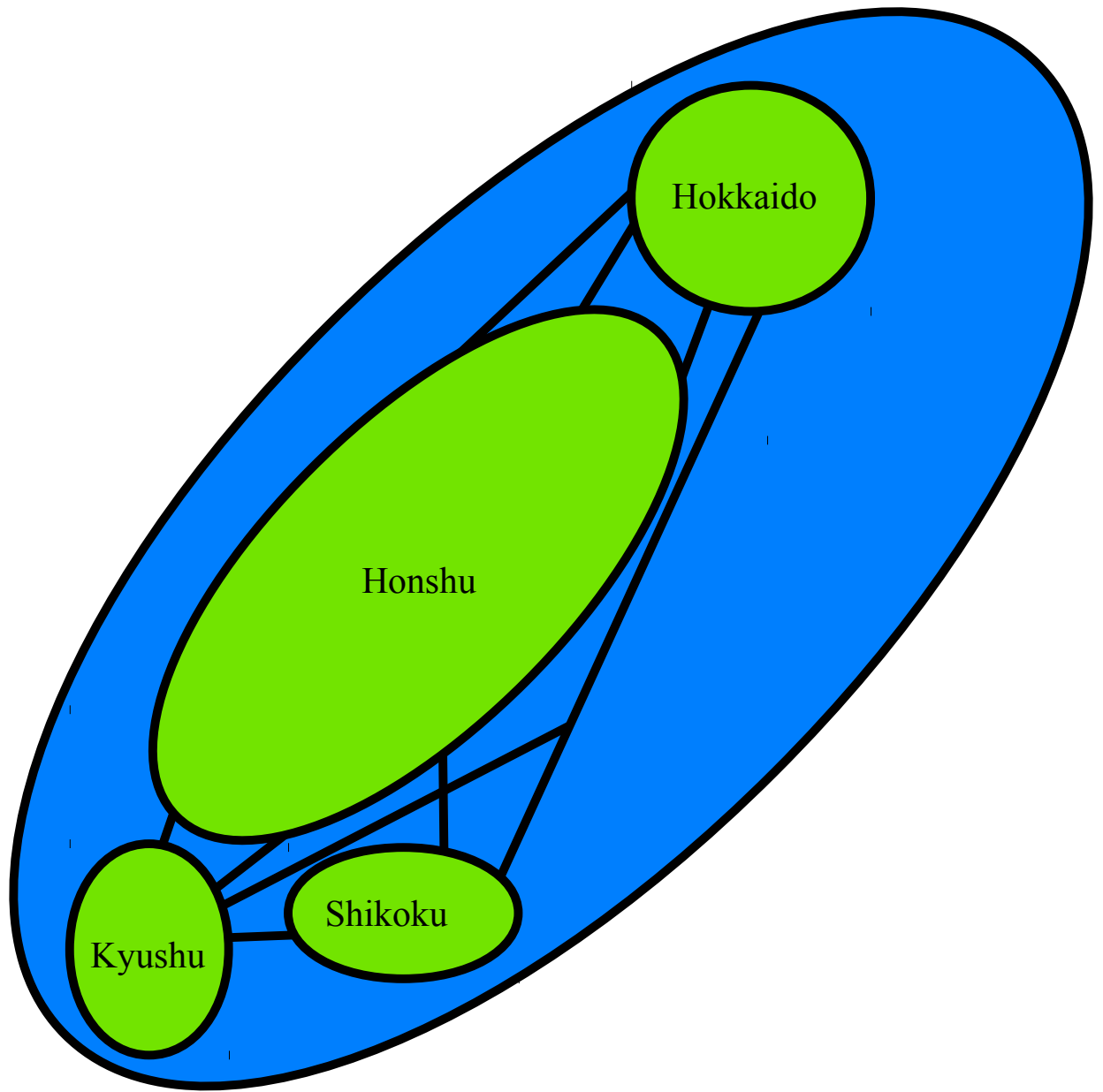

Figura 32. Modelo gráfico do arquipélago japonês

221 PELLETIER, Op. cit., 230

222 As ligações intra-arquipelágicas japonesas podem ser observadas pela plataforma do "Open Street Map", disponível em: $<$ https://www.openstreetmap.org/\#map=10/33.9018/131.8716>. 


\section{Contato}

\subsection{Ponto}

Já o vimos: o ponto, às margens do círculo, significa localidade. Quando acompanhado de setas direcionais (egresso e regresso), é, portanto, atracadouro. Nada mais fácil. Com efeito, setas orientadas para a ilha ou a partir dela reproduzem a relação desse espaço com o mundo que o circunda.

\subsubsection{Vitória (ES)}

Vitória, a "cidade-ilha" por antonomásia, conta com um relevante duo portuário a oferecer: Tubarão, na praia de Camburi, e o porto homônimo e mais importante, no bairro central. Essa duplicidade de terminais deve-se à necessidade já antiga de mais uma alternativa para o escoamento do minério de ferro, que, de seu lado, confere atadura internacional ao espaço capixaba ${ }^{223}$.

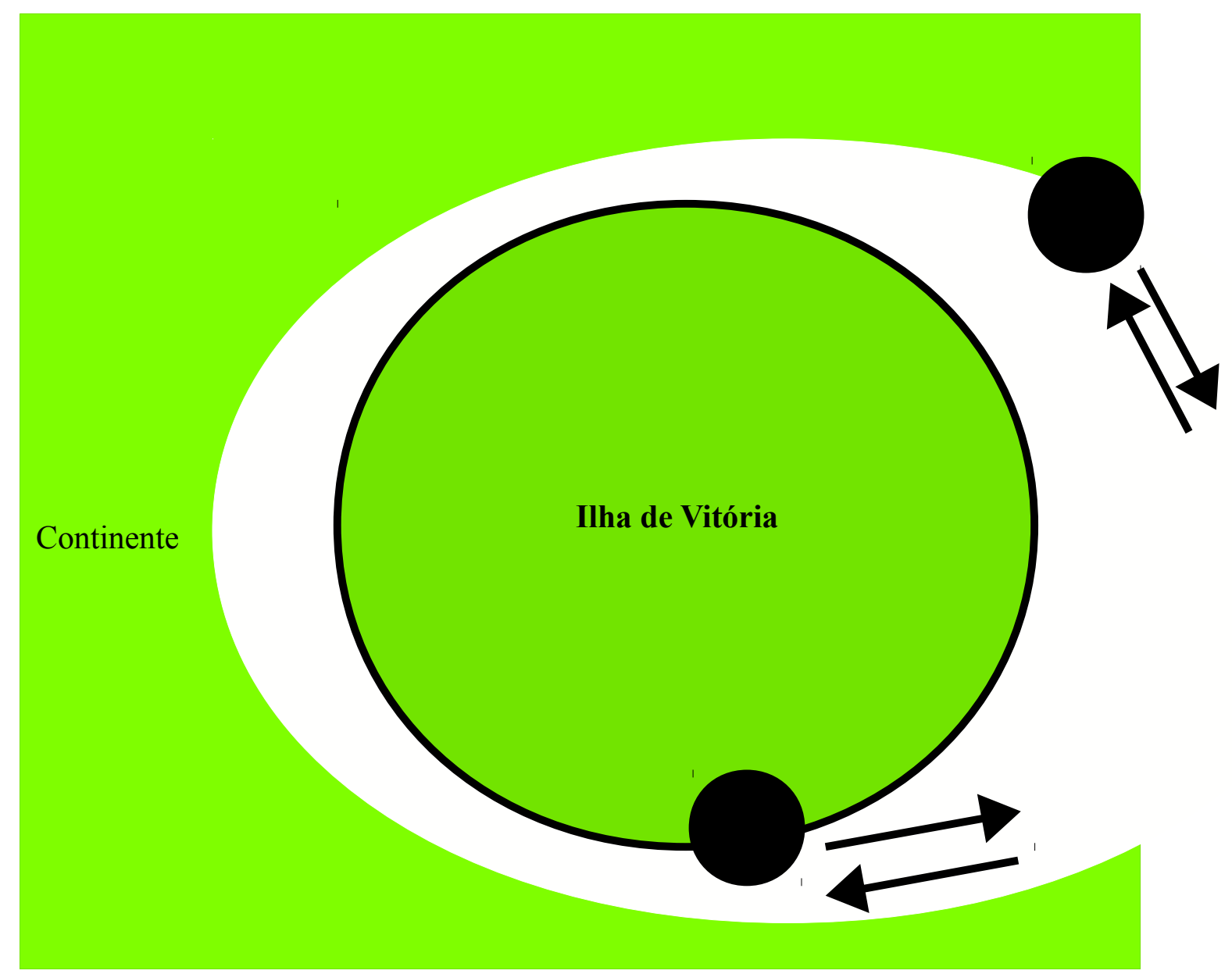

Figura 33. Modelo gráfico da ilha de Vitória (ES)

223 Para mais informações, acessar o sítio eletrônico da Companhia Docas do Espírito Santo (CODESA): $<$ http://www.vitoriaport.com.br/site/>. 


\subsection{Linha}

"Os limites visíveis da soberania de uma nação, como uma fileira de montanhas, um trecho de rio, reforçam a sensação da nação como lugar" ${ }^{224}$. Ora, os limites dão a ideia certa sobre a extensão e as singularidades de um território, assistindo o habitante a criar um conceito sobre o espaço onde habita e a estabelecer relações afetivas com ele. A nação é um exemplo. Mas outras escalas são igualmente possíveis. Neste âmbito, a linha de costa é o limite. Não restam, pois, dúvidas quanto à extensão do espaço insular - é tudo aquilo que estiver recantado pelas marés. Para bem instituir o conceito de ilheidade, é necessário desenhar uma linha grossa, que frise os limites litorâneos.

\subsubsection{Santa Lúcia}

Tal e qual a diminuta república micronésia de Nauru, Santa Lúcia, ilha do barlavento caribenho com não mais que minguados $620 \mathrm{~km}^{2225}$, é uma ilha-país, que seja, encerra-se, tanto do ponto de vista de seu território emerso quanto da ótica de sua identidade nacional, na linha de costa. Constrangimento pela exiguidade territorial, decerto. Mas não somente. Essencialmente, relações topofílicas $^{226}$ são muito possivelmente predispostas pelo ambiente insular, com litoral à vista e sentimento localista.

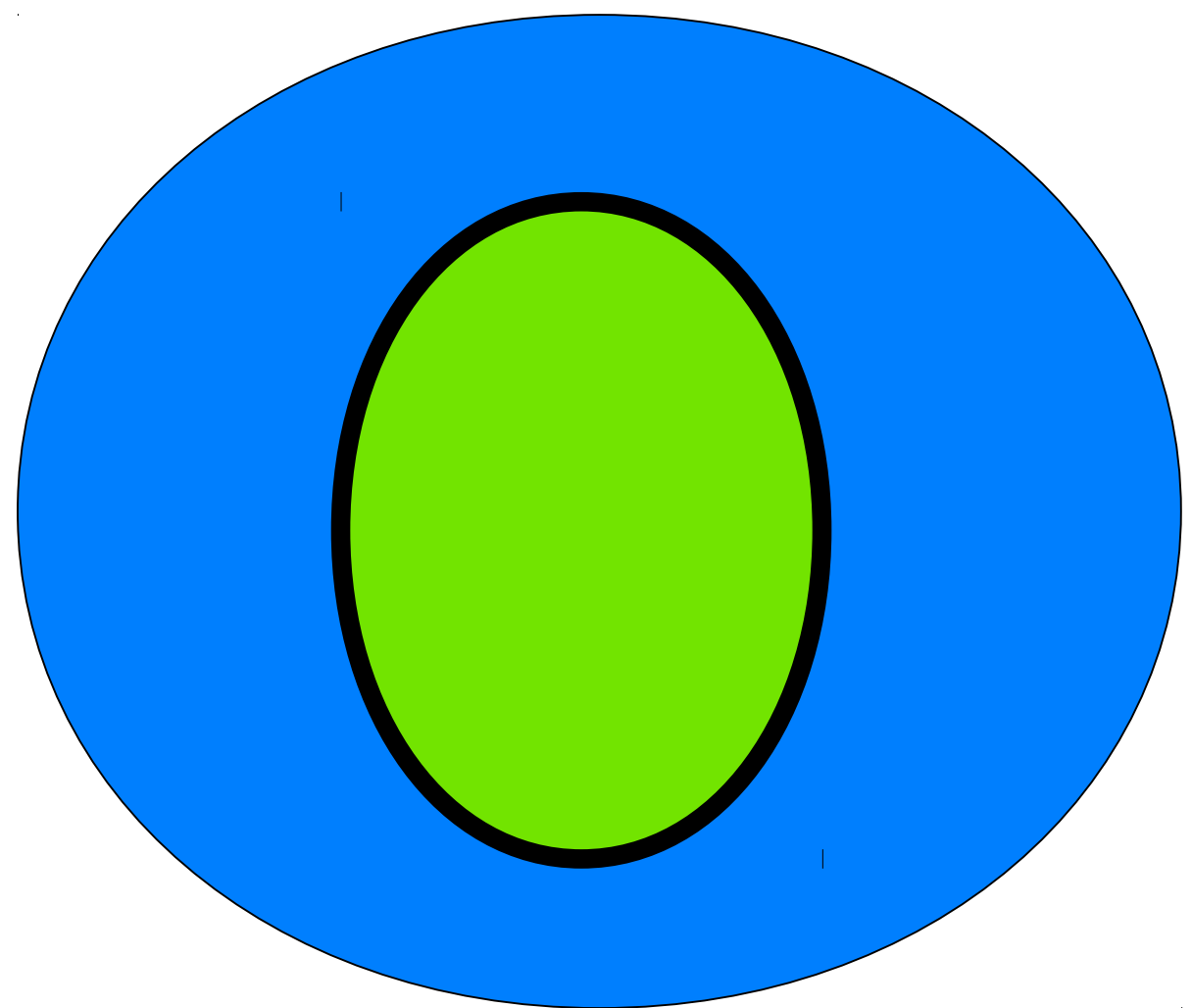

Figura 34. Modelo gráfico da ilha de Santa Lúcia

224 TUAN, 1983, p. 197

225 CIA. The World Factbook. Verbete consultado: Saint Lucia.

226 TUAN, 1980, p. 135 


\section{3. Área}

Localidade é ponto. Se na circunferência exterior, é localidade litorânea. Se com setas direcionais, é marca de idas e vindas. Ao redor do porto, pode-se diferenciar por variáveis visuais de separação - especialmente, pela cor - toda uma zona portuária que se distingua das áreas adjacentes. O mesmo pode ser empreendido para diferenciar água, faixa litorânea e interior terral.

\subsubsection{Itaparica (BA) e São Vicente (SP)}

Duas formas de concepção e atuação no território tendem a colidir nas zonas litorâneas brasileiras. Aliás, já o referimos. A valer, esse processo ganha nitidez com as recentes práticas marítimas modernas, mormente com a especulação imobiliária ${ }^{227}$, que vem somar-se a choques já existentes entre o desejo de conservar e o desejo de abrir-se e transformar. Vejam-se os exemplos das ilhas de Itaparica (municípios homônimo e de Vera Cruz, Região Metropolitana de Salvador, BA) e São Vicente (municípios homônimo e de Santos, Região Metropolitana da Baixada Santista, SP) e as porções continentais a elas praticamente anexas. No primeiro, os loteamentos direcionados à Baía de Todos os Santos e ao Atlântico avançam incontinenti sobre a zona costeira disponível, pactuando-se, para tal, o mercado turístico e o capital financeiro para empreendimentos prediais ${ }^{228}$. No segundo, a paisagem exibe um já antigo contraste entre as áreas florestadas da Serra do Mar (continente) e o Porto de Santos (ilha) ${ }^{229}$, sendo que, de mais a mais, ambas as matrizes, a verde selvagem e a cinzenta urbana, concorrem com projetos de inovação e estruturação, posicionando, lado a lado, ambientalistas e agentes econômicos.
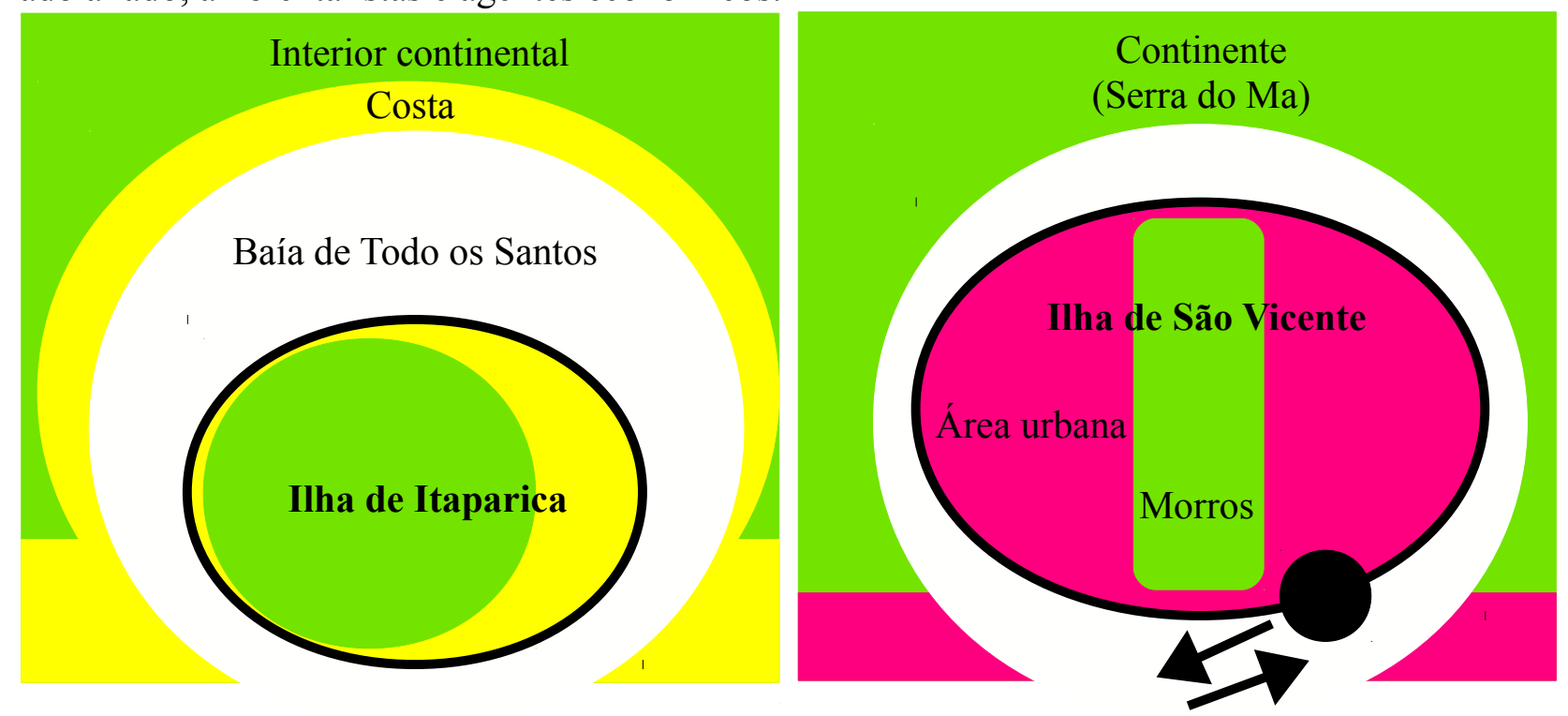

Figura 35. Modelos gráficos das ilhas de Itaparica (BA) e São Vicente (SP)

227 DANTAS, loc. cit.

228 BALTRUSIS et al., 2014, p. 45

229 IBGE e MB, Op. cit., p. 102 


\subsection{Rede}

A eleição da cor para zonas internas de uma ilha não exclui seu emprego para diferenciá-la das demais. Uma única cor por realidade insular exemplifica especialização produtiva, notadamente se ela estiver conectada a outras terras emersas por intermédio de uma rede. Se num contexto não reticulado, seu contraste equivale a isolamento.

\subsubsection{Macaronésia lusófona}

A Geografia está longe de ser uma ciência dita de núcleo duro. Vive, em certa medida, ao sabor da tradição e de circunstâncias toponímicas. Desse modo, os critérios para apontar arquipélagos assentam-se tanto em questões subjetivas do universo cultural do pesquisador como em questões objetivo-taxonômicas, tais quais vegetação, clima, geologia e atividades econômicas. Eleja-se a Macaronésia e ter-se-á um bom exemplo. Esse grupo de ilhas atlânticas faz jus ao nome de batismo dado pelos ibérios - etimologicamente, "ilhas afortunadas". Do prisma biogeográfico, aliás, a unidade desse arquipélago justifica-se: já na década de 1970, Robinson ${ }^{230}$ identificou-o como uma das trinta e sete regiões florísticas e faunísticas do globo terrestre. Tal região é idem encruzilhada eurafricana de espécies animais e vegetais e de gentes, podendo ser subdividida segundo padrões linguísticos em Macaronésia lusófona e Macaronésia hispânica. E aí os consensos podem não se estender para todas as áreas. No caso específico das ilhas de colonização lusitana, as atividades econômicas tornam-nas universos distintos: Cabo Verde baseia-se na pesca e nos serviços; os Açores dependem da pecuária (especialmente bovina, orientada para a produção leiteira); e, finalmente, a Madeira e ilhas sob sua circunscrição são paisagens de exceção, notadamente voltadas ao turismo (ilha principal, Porto Santo) e, em paralelo, à conservação ambiental, na forma de espaços de reserva, cujos nomes são, por si, bem ilustrativos (ilhas Desertas, ilhas Selvagens) ${ }^{231}$.

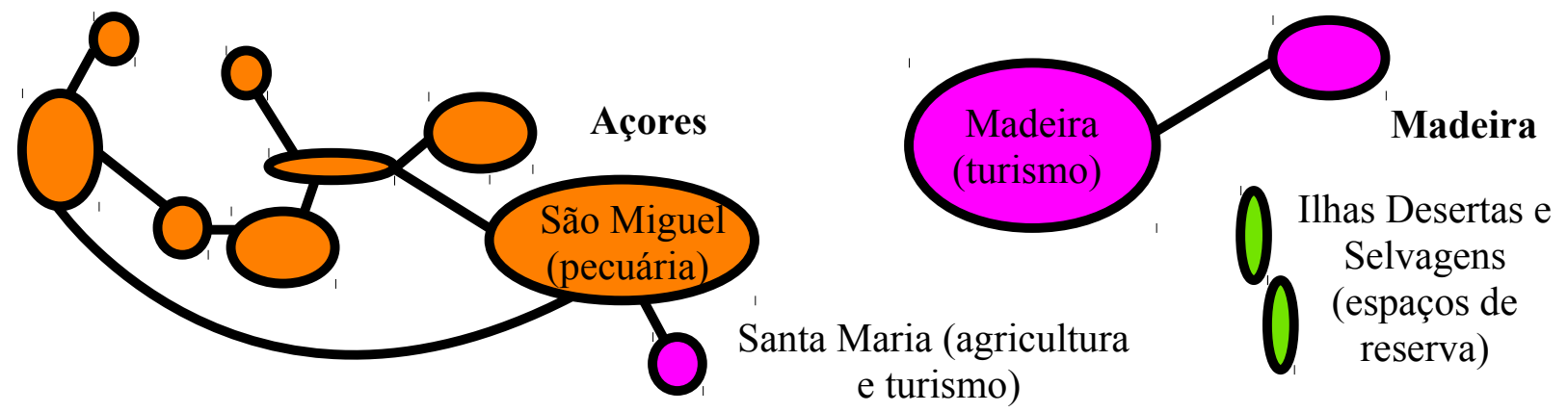

Figura 36. Modelos gráficos da Macaronésia lusófona

230 ROBINSON, 1972

231 Para estatísticas demográficas, sociais e econômicas das Regiões Autônomas dos Açores e da Madeira e da República de Cabo Verde, acesse os Institutos Nacionais de Estatística (INEs) de Portugal, para os dois primeiros casos, disponível em: <https://www.ine.pt>, e de Cabo Verde, para o último caso, disponível em: $<\mathrm{http}: / /$ www.ine.cv/>. 


\section{Tropismo}

\subsection{Ponto}

$\mathrm{Na}$ ocasião de partirem de um ponto, as setas direcionais sugerem localidade especializada no contato com o exterior (porto). Sempre que múltiplas e multidirecionais, não sinalizando nenhum lugar em particular, valem para toda a ilha. Mostram nexos de todo o seu território com o exterior, seja numa relação de influência, recebimento (ponta das flechas para a ilha), seja de efluência, escoamento (pontas alienadas do interior terral).

\subsubsection{Malta e Cabo Verde}

A questão migratória nos contextos insulares é uma das mais em voga na atualidade. Eutopia insular, utopia além-mar. Esse binômio explica, de forma dialética talvez, a identidade do ilhéu construída na ilha e pela ilha (ilheidade) por meio do mar, limite antecedente, via consequente. Dada a baixa capacidade de resiliência combinada a uma exiguidade de área de algumas ilhas, basta essa transmutação da água em estrada para projetar o ilhéu para o exterior, espaço novo que indubitavelmente o conduzirá a um encontro consigo mesmo, com sua ilheidade antes latente, agora aparente. Até porque, "nos diferentes estudos sobre as práticas transnacionais cabo-verdianas, tem-se apontado [inclusive] como a rede transnacional reforça a percepção dos cabo-verdianos sobre o que partilham entre si" $^{{ }^{232}}$. Na Europa, a atual crise migratória robustece a magnitude e o significado desses fluxos humanos e identitários. Assim, se Cabo Verde era o exemplo clássico de ilha-primórdio, prólogo migratório, Malta representa, na outra extremidade, o molde contemporâneo de ilha-passagem, meio da jornada, para uns, e de ilha-exórdio, epílogo migratório para outros ${ }^{233}$.

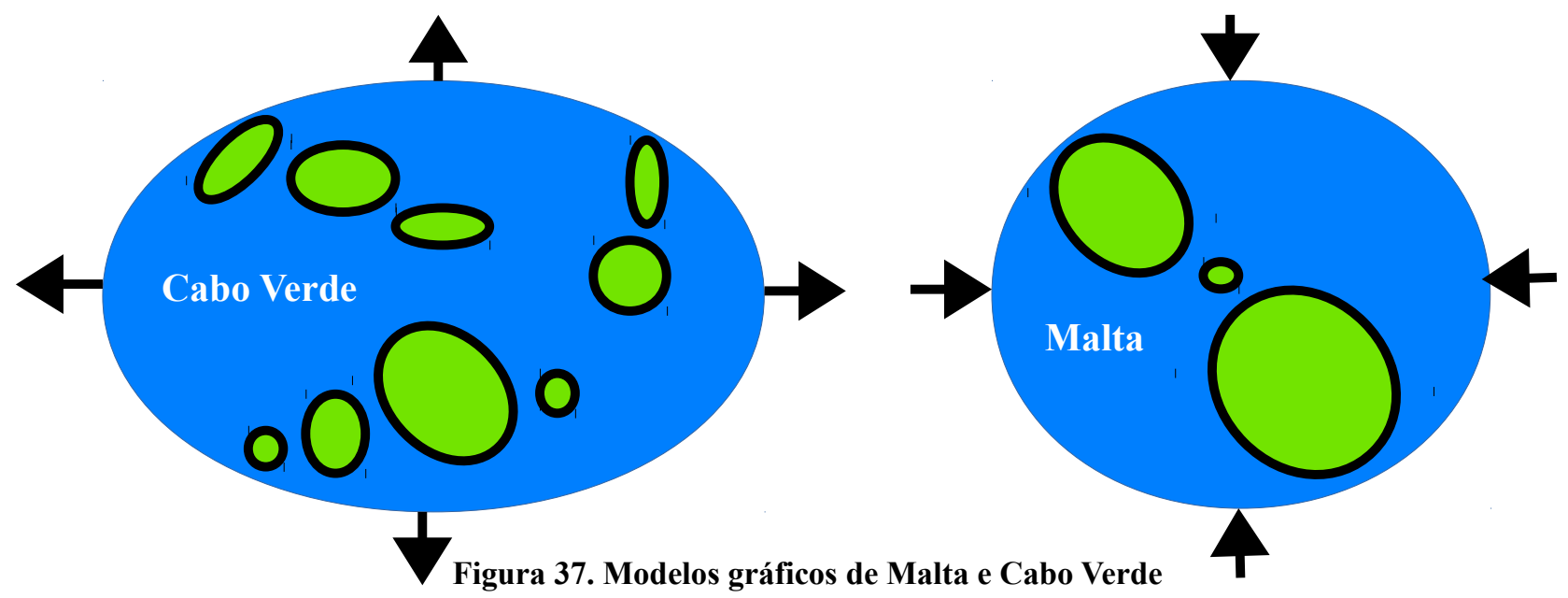

232 ÉVORA, 2006, p. 4

233 As estatísticas da imigração em Malta e em outros membros da União Europeia podem ser acessadas pelo portal da Rede Europeia de Migração (EMN): <http://emn.ie/index.jsp?p=128\&n=229>. 


\subsection{Linha}

A linha de costa assinala limite. À medida que adquire setas direcionais - a ela ortogonais, geralmente - revela as mutações do território insular promovidas pelo mar e enviadas por ele a outras paragens.

\subsubsection{Mosqueiro (Belém, PA)}

A costa é zona de mutação, quer do ponto de vista geomorfológico (dos processos litorâneos), quer do climático (penetração da influência marítima), quer do humano (pelo litoral, as levas de colonização avançam terra adentro). E, tenha-se clareza de raciocínio, os tropismos litorâneos ocorrem não só na direção mar-terra, como também apontam da terra para o mar (caso esse da emigração e suas utopias, da saída para o comércio transnacional). Em tal contexto, elencase a ilha do Mosqueiro, distrito administrativo de Belém do Pará, que, com costas abertas para as baías de Marajó e Santo Antônio, desfruta dessa dupla direção de influências: exterior aquático interior terral (ventos fluviais com função reguladora do clima e aproveitados para esportes como o windsurf) e intestino insular - exterioridade fluvial (pesca comercial artesanal, à moda da comunidade do Cajueiro ${ }^{234}$ ).

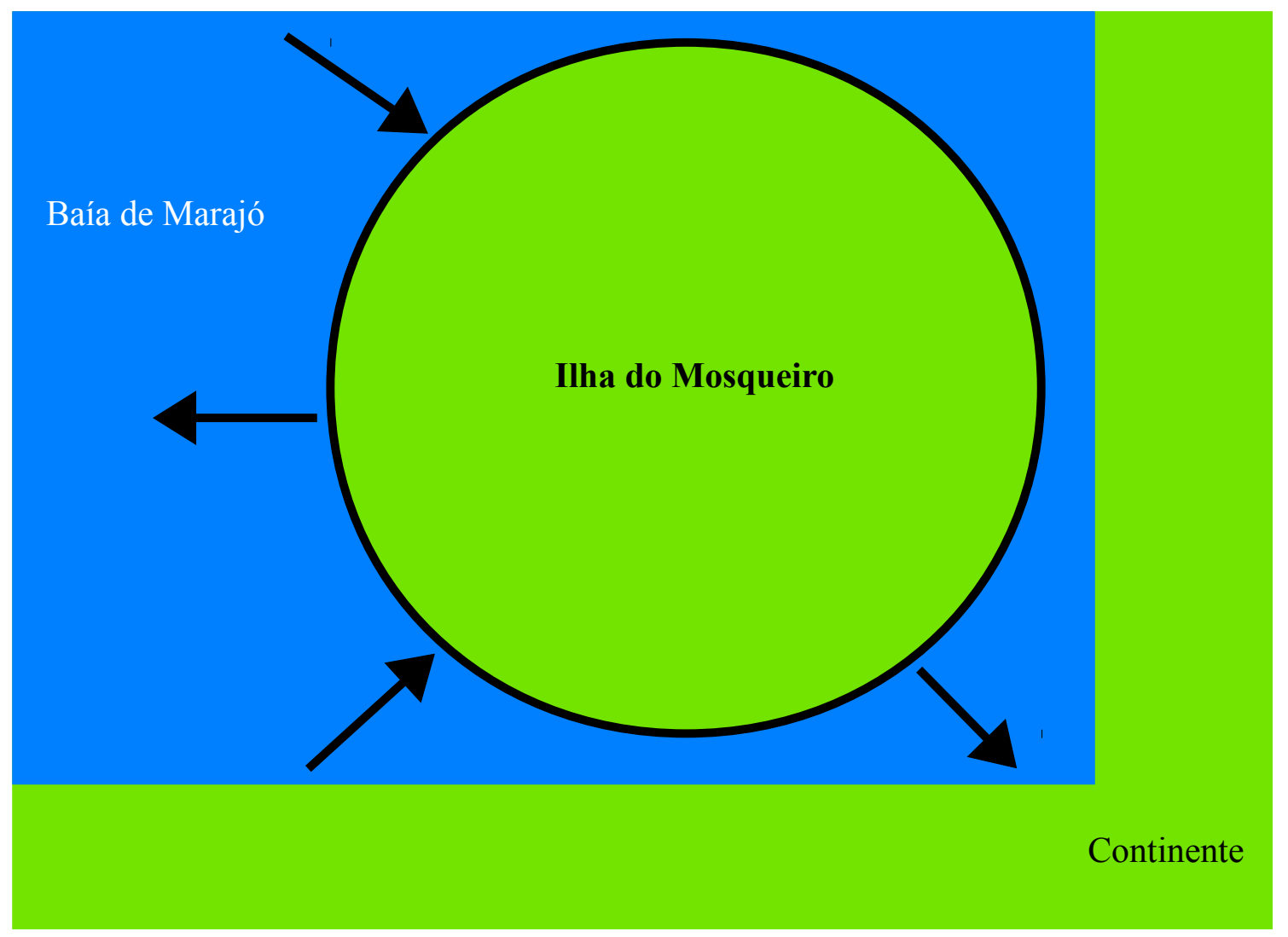

Figura 38. Modelo gráfico da ilha do Mosqueiro (Belém, PA)

234 SILVA, 2015, p. 48 


\section{3. Área}

Linhas paralelas à costa, quando acompanhadas de seta perpendicular rumo ao centro insular, regionalizam os efeitos do litoralismo e da maritimidade.

\subsubsection{Groenlândia}

Caso supracitado, litoralismo e insularidade são conceitos inter-relacionáveis. Quer-se uma ilha ideal, tenha-a apartada pelas águas oceânicas, desvinculada das redes de comunicação e circulação, com espaço exíguo e, mormente, costa sempre à vista. Não obstante, vistos a físiografia do terreno, a morfologia insular, o espaço disponível ou outros impeditivos interiores (de ordem física ou humana), a penetração daquilo que as águas forâneas e a atmosfera sobre elas são capazes de transportar pode dar-se em níveis distintos. Tome-se como exemplo a Groenlândia e isso é percebido de imediato. Num exame de imagens de satélite da porção meridional daquela que é considerada a maior ilha do globo, tratadas segundo o Índice de Vegetação da Diferença Normalizada (NDVI), nota-se que a população e a tundra confrangem-se a beira-mar, restando às terras mais altas interioranas o anecúmeno da calota glaciar. Isso posto visto que a maritimidade possui efeito dúplice de amenizar os extremos de temperatura e oferecer comunicação e subsistência aos residentes ${ }^{235}$.

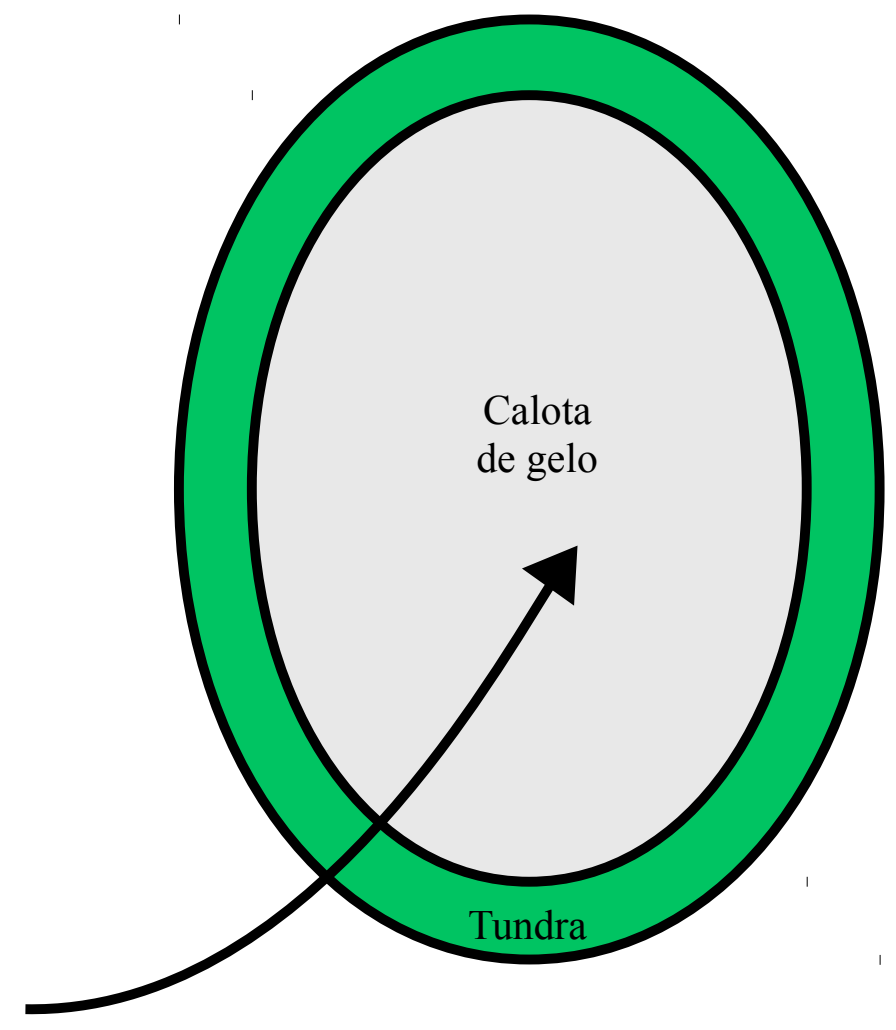

Figura 39. Modelo gráfico da Groenlândia

235 HANSEN, 1991, p. 95. 


\subsection{Rede}

Linhas penetram em terras a partir de uma ilha particular. A Geometria dá foco a esse círculo; a Geografia torna-o centro estratégico; a História coloca-o à prova. Um nó em uma rede de colonização, comércio, ação política ou exercício militar tem de, numa hipótese, ser a origem da rede, e, em situação diversa, ser um meio do caminho valorizado pelo tamanho do círculo e/ou pela posição no desenho.

\subsubsection{Chipre}

Frequentemente, a colonização tece-se segundo uma rede. Apoiando-se sobre pontos nodais, avança sobre os territórios e submete-os a interferências ou autoridades de gêneros distintos. O Chipre, enclave eurasiático que é (concomitantemente, helênico e otomano), teve sua importância geoestratégica salientada durante a Guerra Fria, quando a Grã-Bretanha buscava acesso ao petróleo das Arábias e do Golfo Pérsico, ao passo que os Estados Unidos, para além desses interesses, divisavam um local para o monitoramento das movimentações militares e lançamentos de mísseis soviéticos ${ }^{236}$.

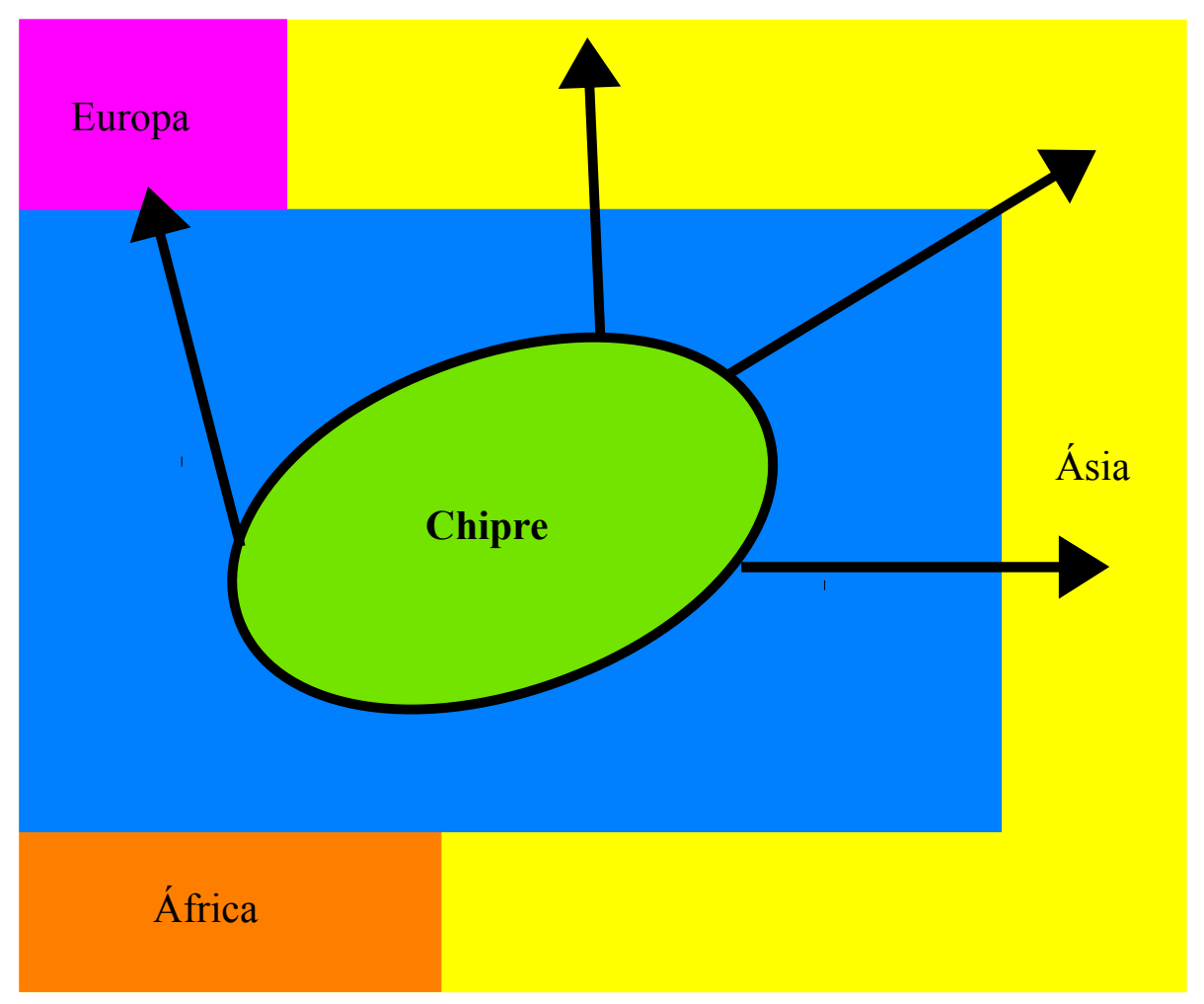

Figura 40. Modelo gráfico do Chipre

236 CID, 2016, p. 17 


\section{Dinâmica territorial}

\subsection{Ponto}

Cada ponto no interior do círculo revela um pequeno efetivo no espaço insular. Dessarte, muitos pontos, muita densidade, seja de pessoas, localidades ou quaisquer outros elementos ou fenômenos. Transcendendo a distribuição dos fatos pelo espaço, os sinais aritméticos de subtração e adição insinuam uma novidade: são movimentos da ilha no tempo e relativamente a outros espaços, façam-se de eclosão, façam-se de encolhimento. De mais a mais, diríamos estagnação se, nas circunstâncias dessa notação, algum círculo nada oferecesse.

\subsubsection{Singapura e Montão de Trigo (SP)}

Já o dissemos e voltamos a afirmar, as ilhas são ambientes essencialmente frágeis, não invulgares são os eventos forâneos que, uma vez as tenham invadido, promovem rápidas transformações em suas dinâmicas territoriais. De quando em quando, representam extremos: superpopulação, de um lado, quando, ligadas a uma rede de comunicação e circulação, desfrutam de uma localização relativamente vantajosa; rarefação demográfica, de outro, quando as perspectivas econômicas são, no mínimo, obtusas para os jovens que, uma vez em contato com o restante da aldeia global, percebem o isolamento como contrariedade de seu destino. Do ponto de vista biológico, o mesmo se dá: há, em um polo, muitos santuários ecológicos, com espécies endêmicas de inestimável valor científico, enquanto, em outro, pela fragilidade que apresentam, há cenários de completa desolação e pouca biota. Caso se queiram exemplos desses polos, no que tange às populações humanas, pegue-se Singapura, no sudeste asiático, e Montão de Trigo, no litoral norte paulista. A ilha oriental é, a sério, a república com maior densidade demográfica do mundo (7.000 hab/ $\left.\mathrm{km}^{2}\right)$ e tem franco crescimento econômico visto que, ao longo de sua história, buscou aliar livre comércio, indústria de transformação altamente diversificada e localização nevrálgica ${ }^{237}$. Outro é o cenário do Monte de Trigo: a falta de diversificação de suas atividades econômicas, o declínio das roças, a míngua de sua população e o considerável desequilíbrio na razão de sexos conduzem a um cenário emigratório aparentemente incontestável ${ }^{238}$.
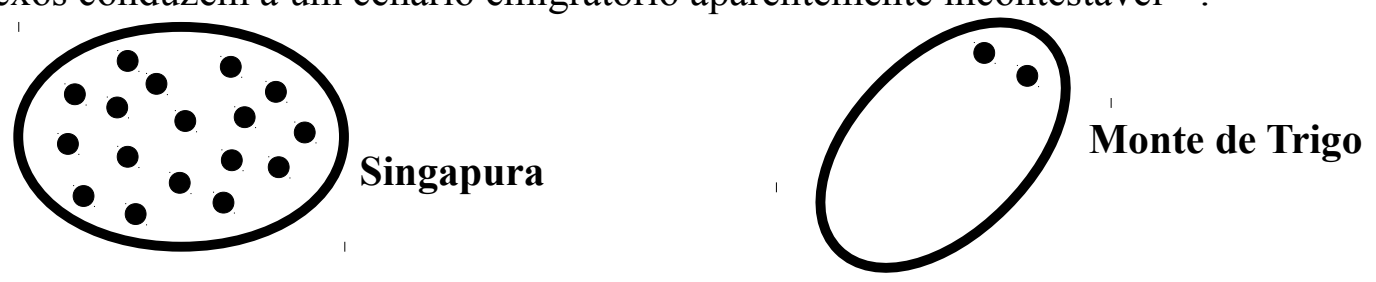

Figura 41. Modelos gráficos de Singapura e Montão de Trigo (SP)

237 CIA. The World Factbook. Verbete consultado: Singapure.

238 BARROS, Op. cit., p. 137 


\subsection{Linha}

Seta direcionada ao interior terral, se favorecida pelo sentido de outra linha (ou polígono) normal à linha de costa, retrata os facilitadores do território, isto é, os fatores geográficos favoráveis a dinâmicas específicas, sejam eles o relevo, alguma estrada ou uma rede já estabelecida de cidades.

\subsubsection{Ilha Grande (RJ)}

Redes internas e características fisiográficas do terreno podem conduzir à penetração de ares de além-mar, afora, é claro, aventar, sempre que possível, a comunicação entre duas localidades. O relevo tem, assim, papel tanto na ocupação quanto, quiçá, nas dinâmicas espaciais que dela decorrem. Ilha Grande, no litoral de Angra dos Reis, é um excelente exemplo: um exame de sua carta topográfica ${ }^{239}$ permite distinguir uma estrada (elemento planimétrico) orientada na direção NE/SO, que parte da Vila do Abrãao em direção à praia dos Dois Rios e que repousa em uma facilidade altimétrica já existente, que seja, uma linha de sela entre as vertentes do Pico do Papagaio (em serra homônima) e do morro do Ferreira (na serra do Abraão).

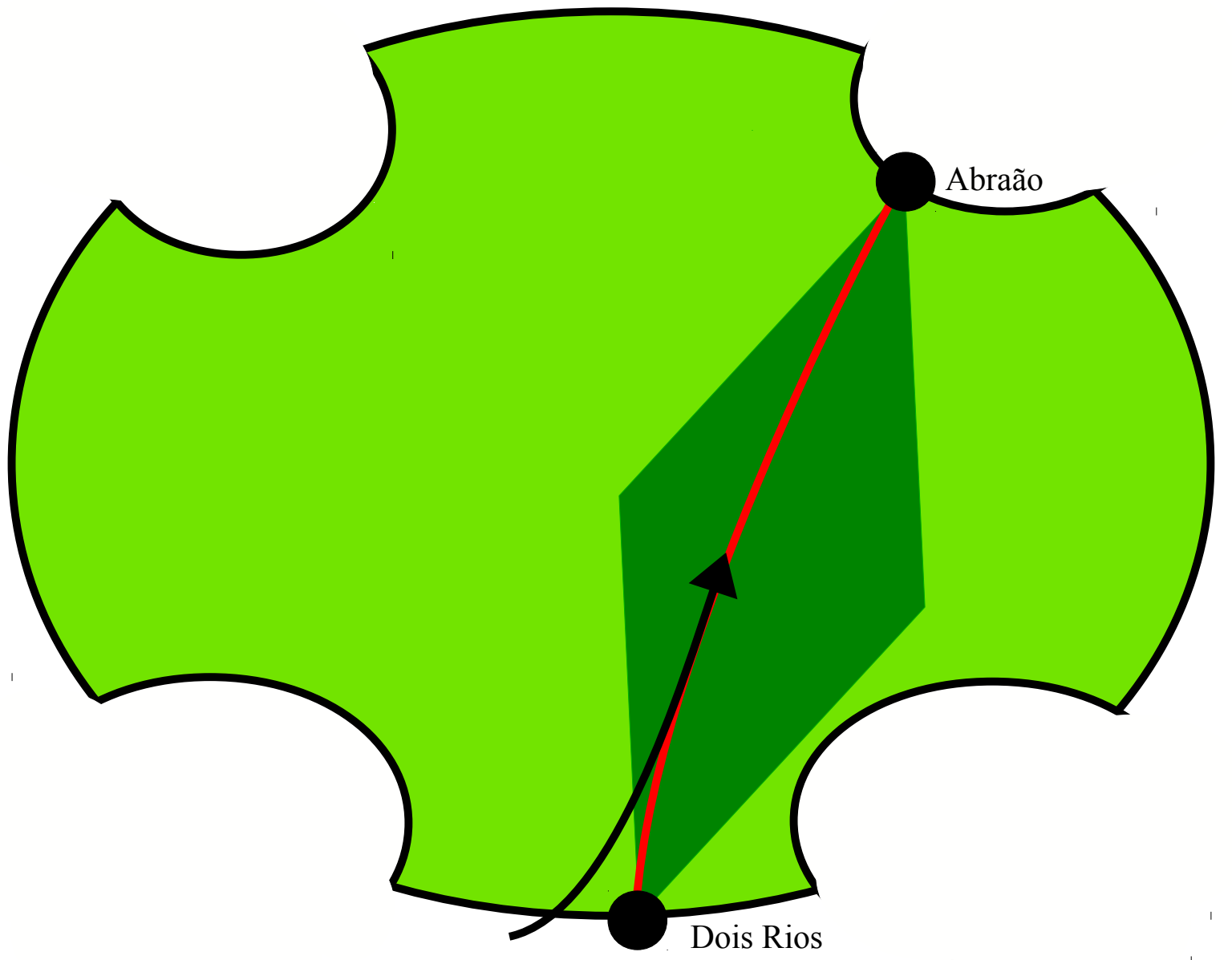

Figura 42. Modelo gráfico da Ilha Grande (RJ)

239 Para mais informações, consultar a carta topográfica SF-23-Z-C-II-2 (folha Ilha Grande), elaborada pelo IBGE, na escala 1:50.000, em 1974, no âmbito do Mapeamento Sistemático Brasileiro. Disponível em: $<$ http://biblioteca.ibge.gov.br/visualizacao/mapas/GEBIS\%20-\%20RJ/SF-23-Z-C-II-2.jpg>. 


\section{3. Área}

Para exprimir, em termos gráficos, um processo histórico, tanto de ordem natural como humana, de conexão e desconexão entre ilhas ou entre uma ilha e um continente, faça-se o seguinte. Primeiramente, colora as terras e as águas de modo distinto (o discernimento cromático entre ilha e continente coloca-se ao sabor das circunstâncias). Posteriormente, junte as terras por meio de uma zona de mesma cor (se o desejo for mostrar vínculo) ou separe-as pela cor das águas (se o intuito for manifestar apartamento). Na hipótese de a cisão produzir especialização insular (isto é, particularidades no contexto de outras terras), os fenômenos em terrenos distintos devem ser tratados por cores, formas ou orientações diferenciadas. Quando um quadrado no continente representa uma espécie de ser vivo, um losango na ilha pode sugerir outra espécie.

\subsubsection{Queimada Grande (SP)}

Eventos pretéritos, quer de nossa história natural, quer de nossa história social, têm a capacidade de atar e romper relações entre terras emersas na mesma proporção, implicando certos endemismos (perspectiva biológica) e localismos (perspectiva humana) nos espaços insulares. A jararaca-ilhoa (Bothrops insularis) é um exemplo de especiação decorrente do isolamento insular. Típica da ilha da Queimada Grande (não sem razão, referida coloquialmente como "ilha das Cobras") - a $30 \mathrm{~km}$ da costa de Itanhaém (SP) e dela apartada há 11.000 anos, finda a glaciação pleistocênica ${ }^{240}$-, esse ofídio, sem predadores naturais, colonizou o espaço disponível e especializou-se ao longo de séculos de seleção natural para que fosse hábil em inocular um veneno com rápida ação mortífera e que, por conseguinte, garantisse sua alimentação em um espaço concomitantemente pequeno e com presas de fácil escape (aves).

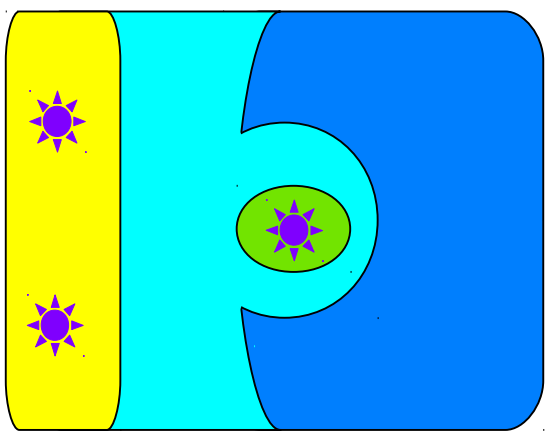

Glaciação pleistocênica: Rebaixamento do nível do mar

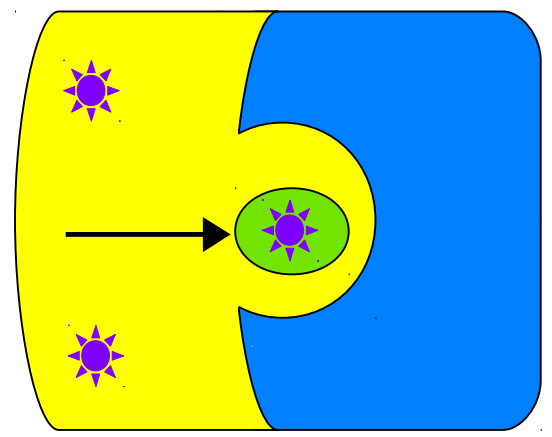

Glaciação pleistocênica: Ligação continente-ilha

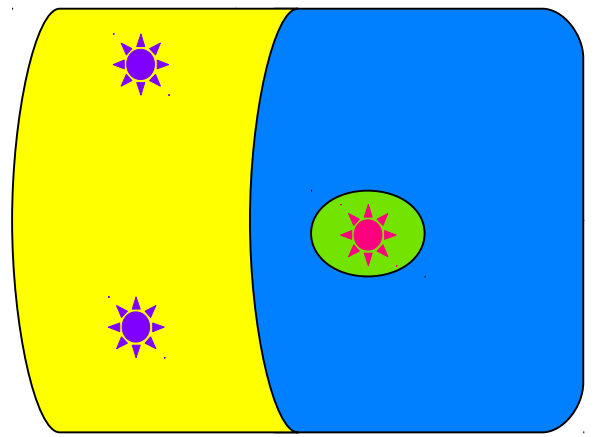

Holoceno: secessão continente-ilha e especiação ofídica

Figura 43. Modelo gráfico da ilha da Queimada Grande (SP) 


\subsection{Rede}

Áreas grandes associadas por hastes flechadas a áreas pequenas propõem relações de povoamento entre continentes e ilhas. As direções e os tamanhos das flechas e dos fluxos coincidem. O mesmo se dá com a continuidade dos traçados. Por resultado, estabelece-se uma gradação do povoamento, de consolidado a insipiente ou, mesmo, inexistente.

\subsubsection{Ilhas paulistas do Mar Virado, das Couves, Comprida (Ubatuba) e Anchieta}

Não se exige vagar pelos rincões da Terra para encontrar tipos característicos de povoamento insular. Em Ubatuba, algumas ilhas dispersas próximo à costa já nos oferecem algumas possibilidades. Dadas as condições geográficas e vistos os processos históricos de uma realidade insular, ter-se-á a presença humana em graus distintos de povoamento dos lugares, alteração da paisagem, domínio do território, organização do espaço e frequência de atividades. Dessa forma, se a ilha da Queimada Grande não somente é desabitada como também hostil a qualquer tipo de projeto de colonização (afora seu valor ambiental inestimável, reputado sobretudo ao endemismo ofídico), há ilhas ubatubenses já com o distintivo do homem, com os seguintes padrões de ocupação: temporário (para pernoite ou afazeres específicos, caso do Mar Virado), sazonal (de veraneio, caso das Couves e Comprida ${ }^{241}$ ) e consolidado ou permanente (caso da Anchieta) ${ }^{242}$.

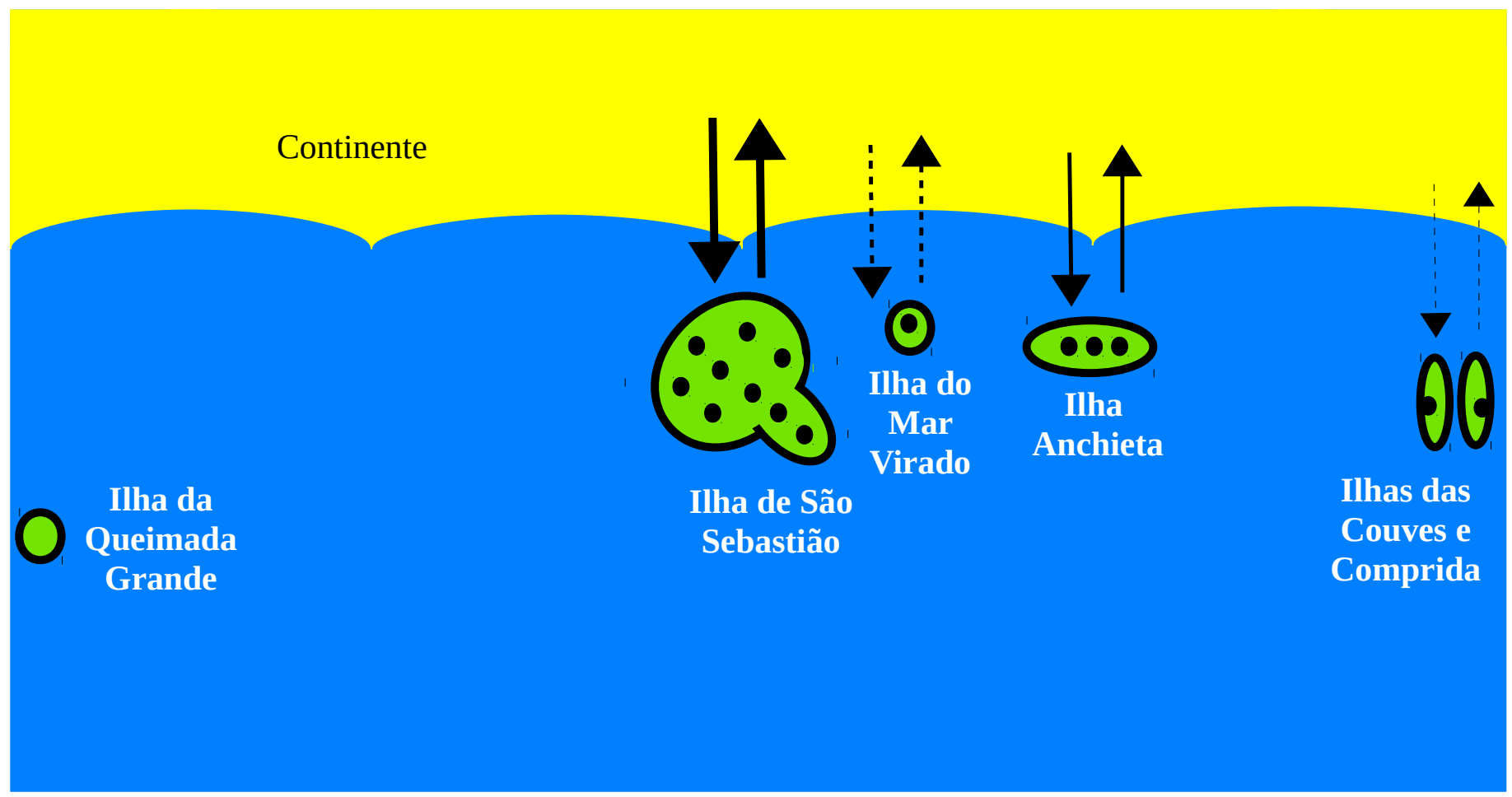

Figura 44. Modelo gráfico das ilhas paulistas do Mar Virado, das Couves, Comprida (Ubatuba) e Anchieta

241 Observa-se que a referência aqui é a ilha pertencente aos domínios de Ubatuba, no litoral norte de São Paulo, e não o município de mesmo nome, no litoral sul do estado, de que falamos páginas atrás.

242 PEREIRA et al., Op. cit., p. 14-23 


\section{Hierarquia}

\subsection{Ponto}

Círculos de vários raios, ilhas de tamanhos distintos. Eis a relação. E não apenas em termos de área física (em hectares), porém, por intermédio de outras métricas, segundo poder de influência, grau de atividade, população absoluta ou relativa, pujança econômica.

\subsubsection{Comores}

A União de Comores, no Índico, faz jus a seu antenome oficial. É, de fato, uma comunhão de povos agrupados em torno de um único espírito nacional: árabes, persas, hindus, indonésios, bantos e malgaxes amalgamaram-se (não sem conflitos) ao longo do tempo e ocuparam desigualmente seus lugares nas terras emersas disponíveis. Como princípio basilar da realidade geográfica, novamente, é ocasião para concentrar-se em torno da gravitação. Deveras, o arquipélago pode ser resumidamente explicado como um conjunto de ilhotas-satélite em torno de ilhas principais (tanto nas posições de área quanto nas de população e poder de influência). Citem-se, assim, em ordem decrescente segundo esses critérios, a Grande Comore (com Moroni, a capital), Anjouan (com Moutsamoudou, o segundo centro urbano em poder de influência, e Domoni) e, a termo, Mohéli (com Fomboni). Exclua-se, está claro, a ilha de Mayotte, fisicamente aderente ao arquipélago, politicamente subordinada à França ${ }^{243}$.

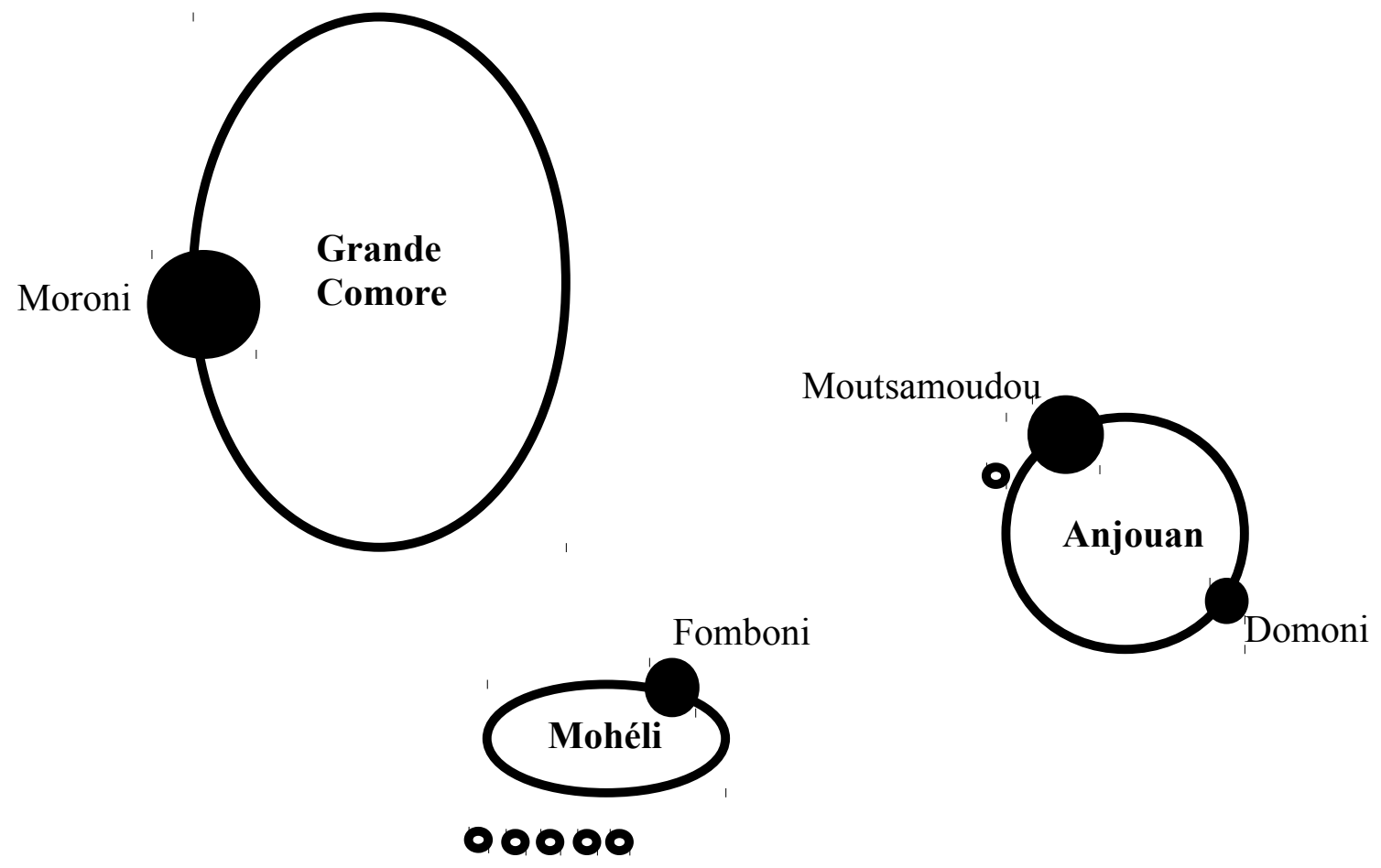

Figura 45. Modelo gráfico do arquipélago de Comores

243 CIA. The World Factbook. Verbete consultado: Comoros. 


\subsection{Linha}

Quando expostas as malhas, as linhas ora eram internas aos círculos (limites intrainsulares), ora exteriores a eles (limites interinsulares). Em uma análise transescalar, elas assumem-se por dentro e por fora, corroborando um entendimento hierárquico das unidades político-administrativas. Exemplificando-se: a localidade no contexto da região, a região no contexto da ilha, a ilha no contexto do arquipélago.

\subsubsection{Filipinas}

Com 100 milhões de habitantes distribuídos por um território esmigalhado em mais de 7.000 fragmentos de terra ${ }^{244}$, as Filipinas concorrem com seus parceiros asiáticos para uma crescente relevância no cenário internacional. E não debruçamos nosso olhar sobre o arquipélago apenas em virtude de seu crescimento econômico, porém, mormente, por força de seu retalhamento territorial, interessantíssimo para os estudos geográficos. Desse caráter, dimanam questões como: qual a influência da condição arquipelágica de um país na sua unidade política? Quais os trunfos e os constrangimentos do parcelamento superespecializado do território? Quais os fatores para a autonomização administrativa de algumas regiões? Eis o inquérito. Que investigações posteriores deem conta dessas indagações, parece-nos imperioso.

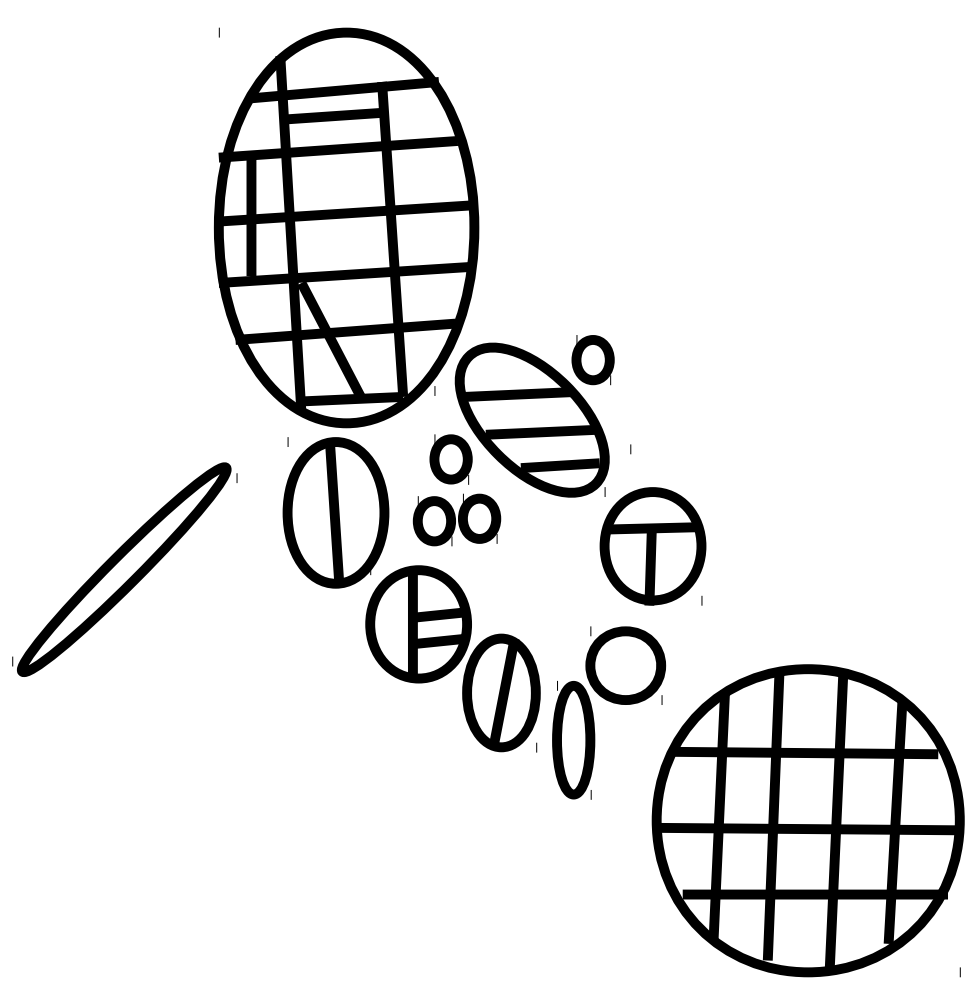

Figura 46. Modelo gráfico das Filipinas

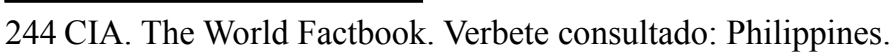




\section{3. Área}

Elipses ou circunferências são capazes de circunscrever concentricamente outras formas geométricas de mesma natureza. Troquem-se as cores, estabeleça-se a concentricidade e obtenha-se uma hierarquia. A ilha verde no mar circundante azul constitui o todo numa ordem de análise. Em outra, hierarquicamente superior, é a unidade, o menor dos fragmentos. Isso porque unidade, parte e todo não são mais que expressões da relatividade universal: o que representa um arquipélago algures, não passa de um subsistema de outro alhures.

\subsubsection{Aruba}

Os fenômenos variam conforme as escalas. Antigo e atual chavão geográfico. E não só. Unidade, parte e todo são conceitos relativos de e em todas as disciplinas científicas. Efetivamente, há copiosos exemplos insulares nesse sentido. Didático é, pois, um exercício com Aruba, pretérita possessão das Antilhas Holandesas, corrente país constituinte do Reino dos Países Baixos. Principiando no maior detalhe e findando na escala regional, Aruba é 1. ilha ao largo da costa venezuelana. 2. Uma das ilhas ABC (Aruba, Bonaire e Curaçao). 3. Parte de um dos arquipélagos de Sotavento. 4. Uma das Pequenas Antilhas. 5. Território do Caribe (América Central Insular) ${ }^{245}$.

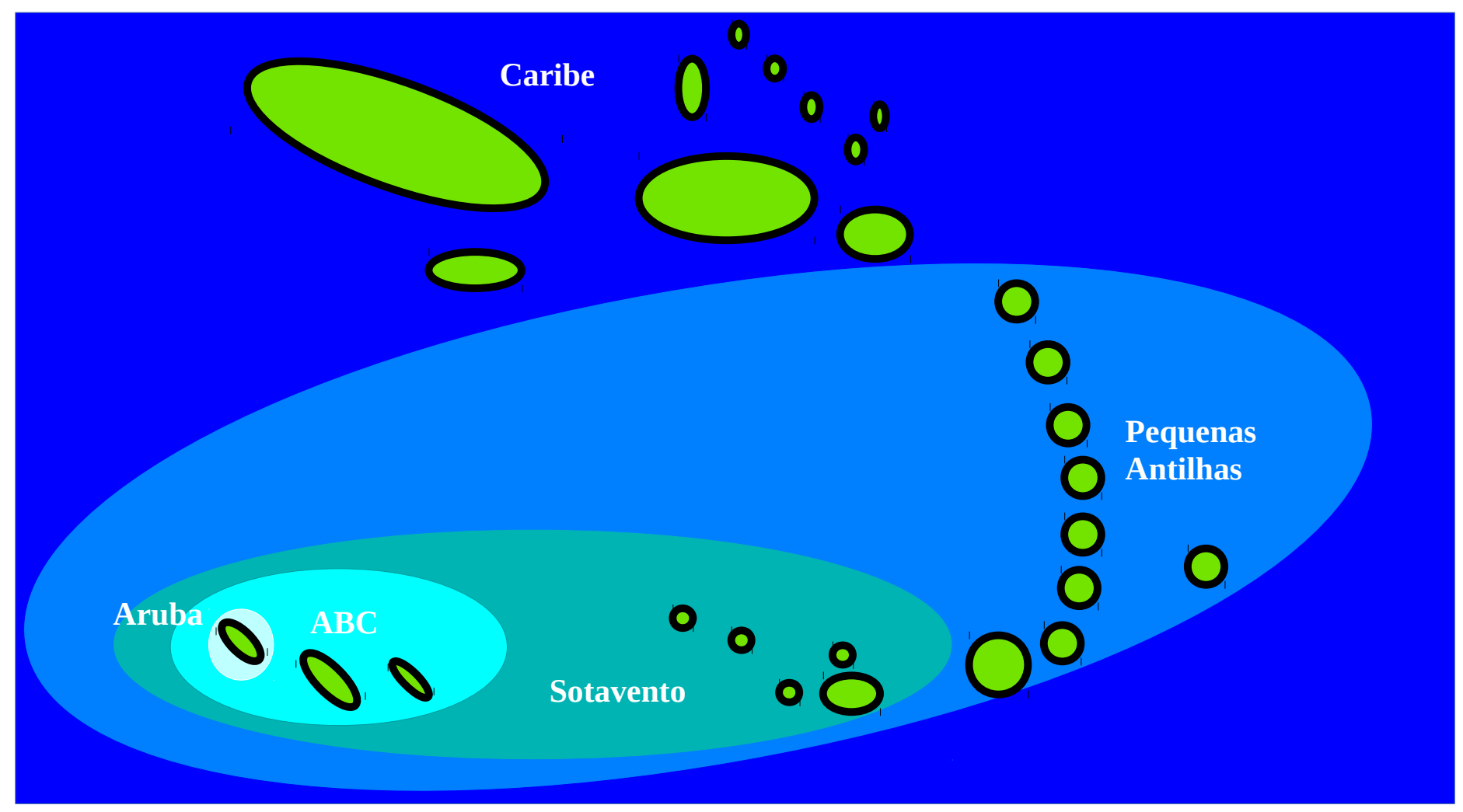

Figura 47. Modelo gráfico das escalas e contextos regionais de Aruba

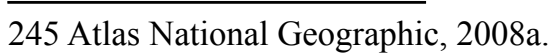




\subsection{Rede}

Adicionem-se aos anéis concêntricos do exercício predecessor as consagradas linhas orientadas e as áreas de maior tamanho. Enfim, assomam-se toda sorte de relações: horizontais (de mesmo patamar) e verticais (hierárquicas); intrainsulares e interinsulares; intra-arquipelágicas e interarquipelágicas; insulares-continentais e insulares-marítimas.

\subsubsection{Dependências da Coroa britânica (ilha de Man, ilhas do Canal)}

O Reino Unido da Grã-Bretanha e Irlanda do Norte é um instigante objeto para aqueles que desejam desbravar as relações políticas possíveis entre os territórios. Acima do fato de ser um Estado soberano internacionalmente reconhecido como unitário, mas, a sério, composto por quatro países constituintes, estrutura-se como uma espécie de administração confederada com as Dependências da Coroa, designadamente, as ilhas do Canal (bailiados de Jersey e Guernsey) e a ilha de Man, sem tratá-las como colônias de ultramar, tampouco como parte integrante do Reino. Com efeito, situam-se entre o nível da Escócia (território constitutivo do governo britânico) e a posição de Gibraltar (possessão à mercê das decisões centrais), possuindo sistemas administrativo, legislativo, legal e fiscal próprios, mas sem qualquer autonomia para assuntos de política externa, como o são os países legalmente independentes da Comunidade Britânica ${ }^{246}$.

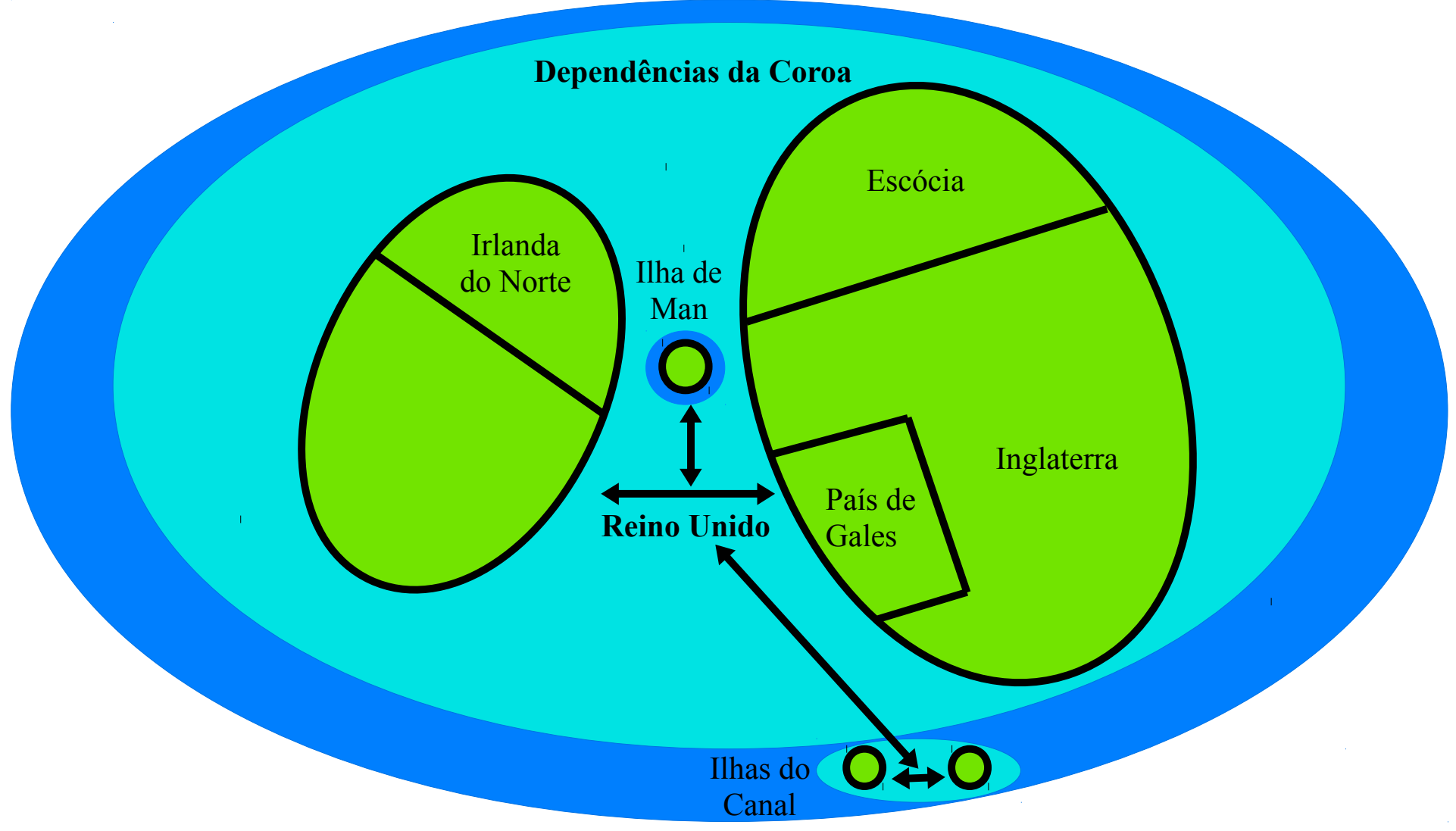

Figura 48. Modelo gráfico das ilhas de Man e do Canal

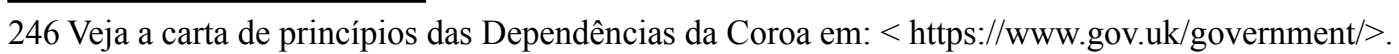


ELEMENTOS DE BASE DA REPRESENTAÇÃO ICÔNICA

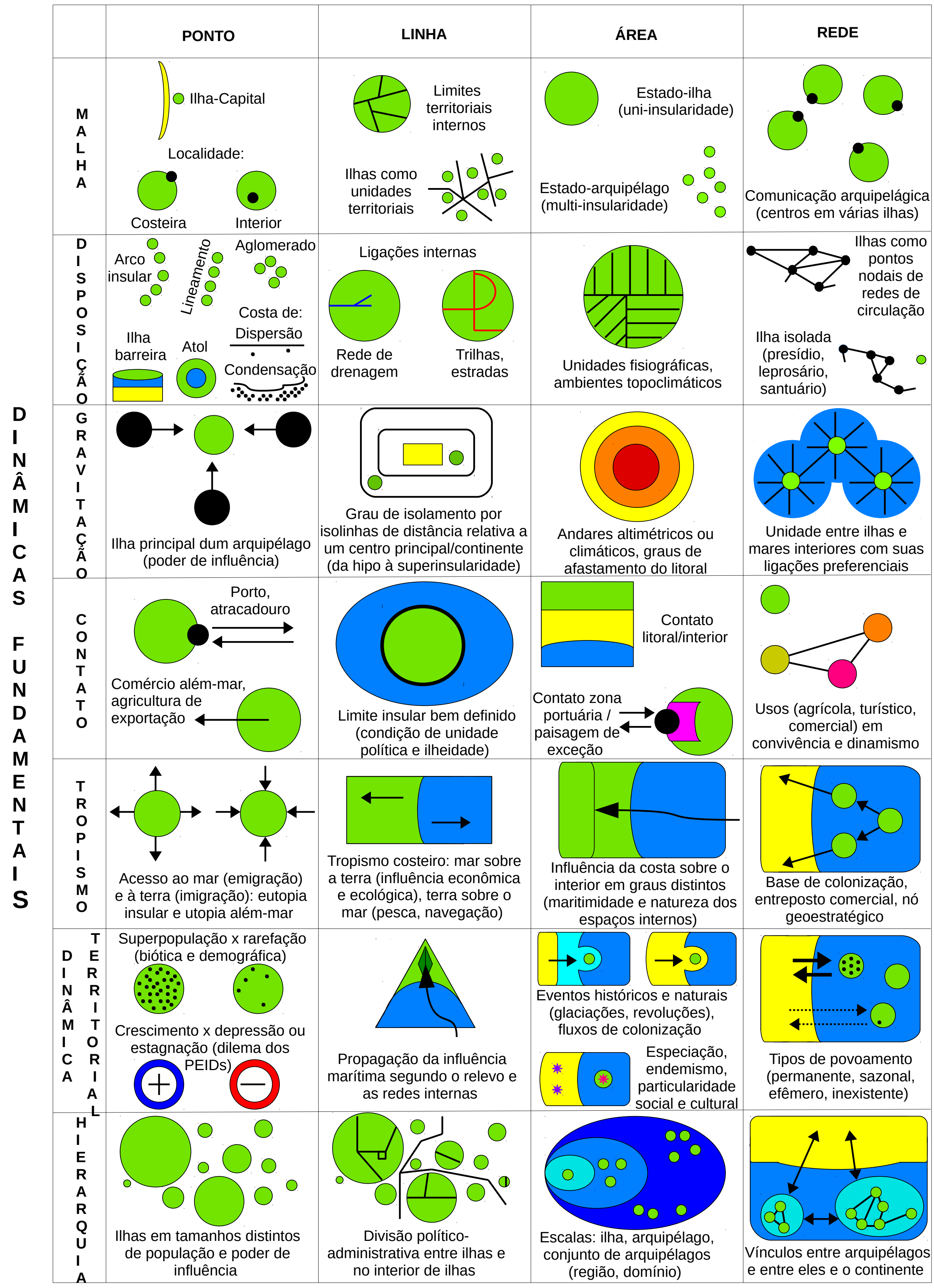




\section{CAP. IV. MODELIZAÇÃO GRÁFICA DA ILHA MONTÃO DE TRIGO}

\section{A. Caracterização geográfica}

\section{Localização e dimensões}

A ilha Montão (ou Monte) de Trigo localiza-se no litoral de São Sebastião, a 10 km da linha de costa, entre a praia do Juquehy e a Barra do Una ${ }^{247}$. A $27 \mathrm{~km}$ de Alcatrazes ${ }^{248}$, figuram, em raio próximo, As Ilhas, a ilha dos Gatos e a ilha das Couves, todas desabitadas. Em termos de

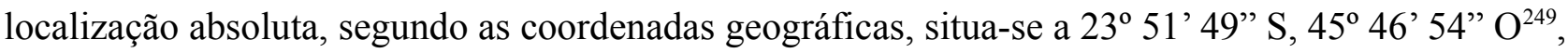
e, em coordenadas planorretangulares (projeção Universal Transversa de Mercator, Fuso 23, Sistema Geocêntrico para as Américas - SIRGAS 2000), a $420.600 \mathrm{~m}$ E, $7.360 .600 \mathrm{~m} \mathrm{~N}^{250}$. Com efeito, está posicionada na plataforma continental do Atlântico, ao largo do litoral norte paulista.

Dada esta localização, para alcançá-la, é necessário, por intermédio da rodovia Rio-Santos, acessar o promontório entre as praias supracitadas e, de lá, com barco motorizado e se as condições meteorológicas estiverem favoráveis, percorrer uma distância-tempo de aproximadamente 20 minutos. Caso a embarcação ou o estado de tempo atmosférico sejam diversos ou, quiçá, adversos, pode-se demorar próximo a uma hora para atracar no costão monteiro.

A ilha não está nem na rota das embarcações comerciais (que atracam no porto de São Sebastião), nem em boa parte das embarcações turísticas, o que, de saída, contribui para aumentar sua insularidade. Realmente, note-se que não é apenas a distância topográfica em relação ao continente que constitui um fator de isolamento, mas também seu apartamento topológico frente às rotas de navegação. Em contrapartida, dentre os barcos pesqueiros e os mergulhadores, o Montão tem adquirido, ano após ano, certa notoriedade, mormente sobre as embarcações com partida no litoral dos municípios de São Sebastião, Caraguatatuba e Ilhabela ${ }^{251}$.

Com alta declividade e formato elíptico, a toponímia lhe faz justiça. Bem se a assemelha a

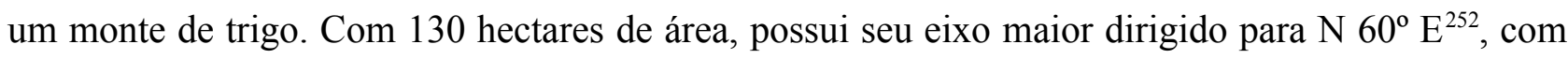
comprimento aproximado de 1,5 km. Fisiograficamente, a ausência de litorais arenosos e a presença constante de matacões arredondados por efeito erosivo oferecem à ilha uma orla rochosa estável,

247 ENRICH ROJAS, 2000, p. 1

248 LIMA, 2014, p. 13

249 Segundo folha SF-23-Y-D-V-1 (Salesópolis). Disponível em: <http://biblioteca.ibge.gov.br/visualizacao/mapas/ GEBIS\%20-\%20RJ/SF-23-Y-D-V-1.jpg>.

250 Coletadas em campo por ponto de GPS no sistema geodésico WGS 84 e, em trabalho ulterior de gabinete, convertidas para SIRGAS 2000.

251 SILVA, 2014, p. 30

252 COUTINHO e MELCHER, 1973, p. 244 
sem grandes articulações que chamem à vista, porém com pontos de referência de inolvidável interesse para moradores e pesquisadores.

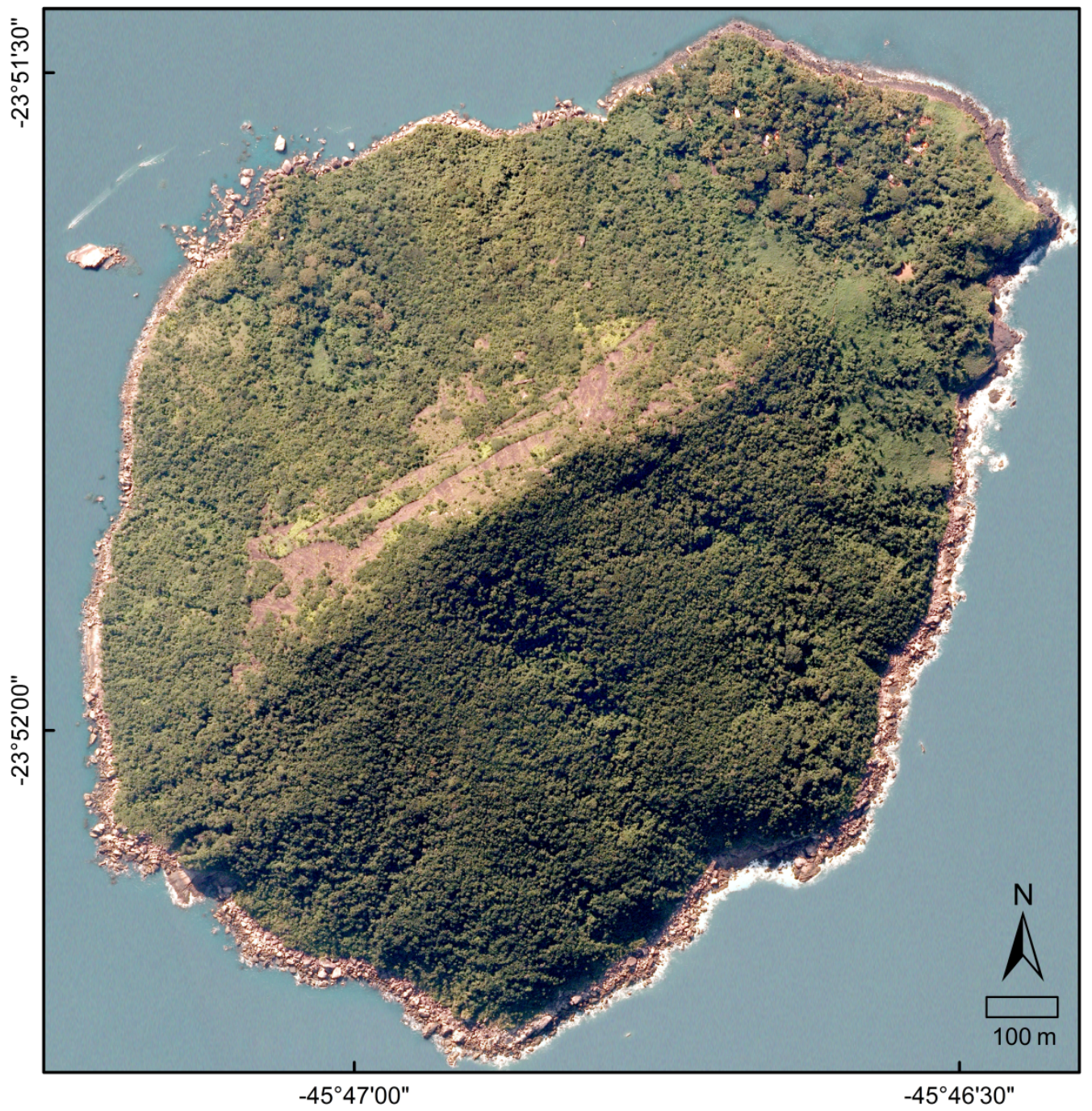

MONTÃO DE TRIGO SOB A ÓTICA DA ORTOFOTOGRAFIA

Elaboração: Menegatto, 2017 Base de referência: Ortofotos - Emplasa (2011)

Figura 49. Ortofotografia da ilha Monte de Trigo. Fonte: Emplasa (2011) 


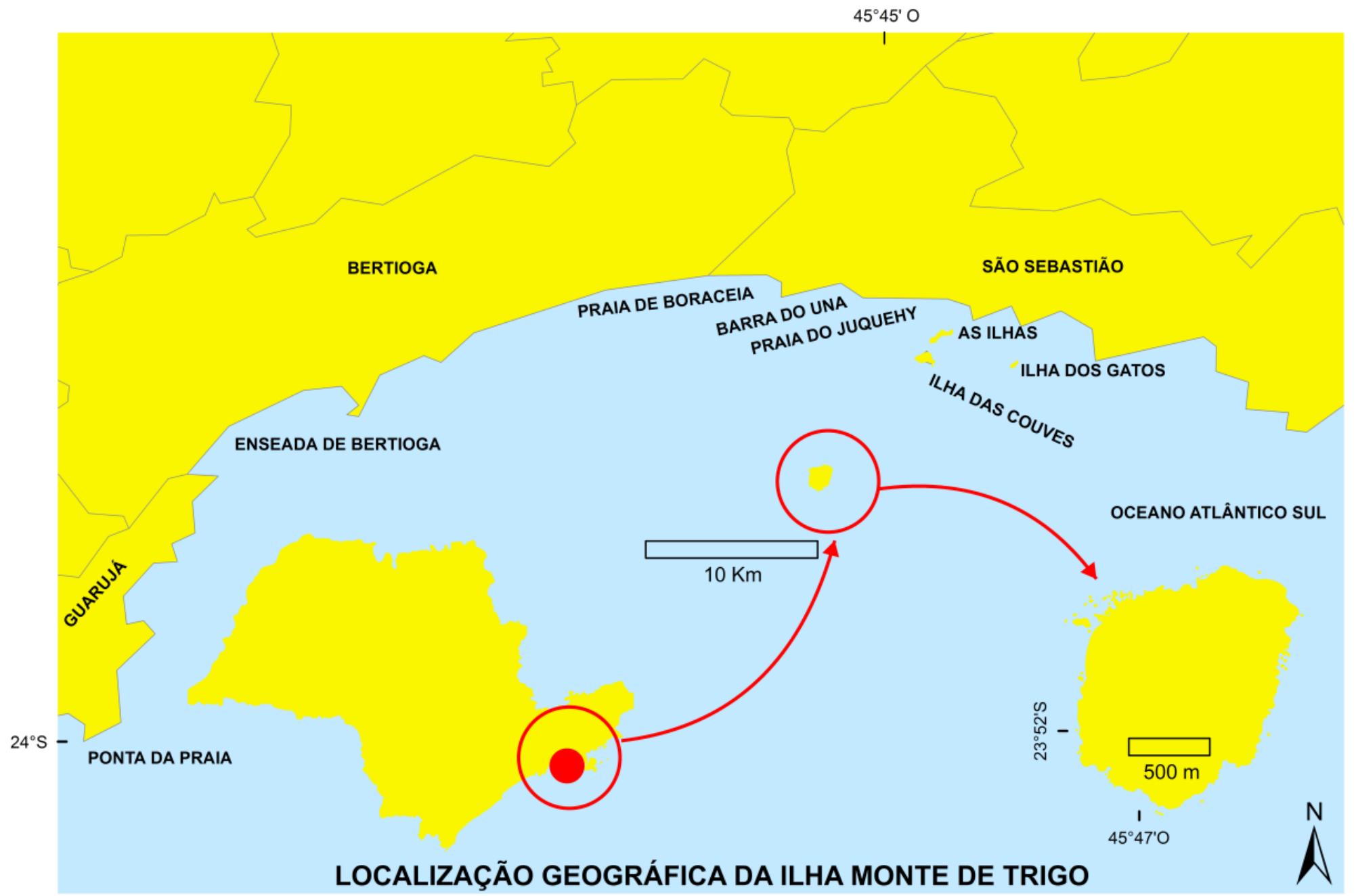

Elaboração: Menegatto, 2017
Bases de referência: Ortofotos - Emplasa (2011); Limites Muncipais - IGC (2015); Limites Estaduais - IBGE (2010) 


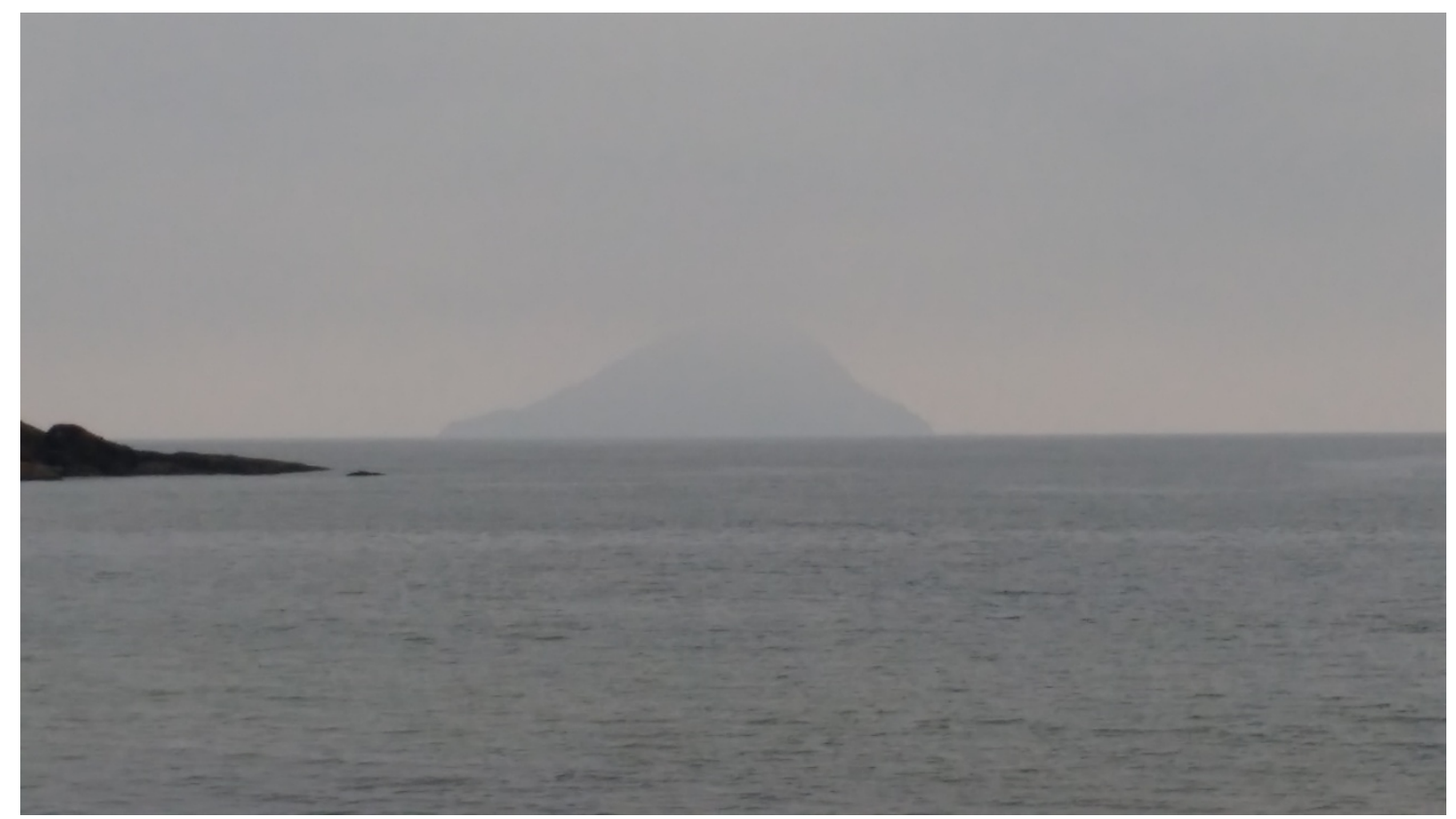

Figura 51. Fotografia da ilha Monte de Trigo vista da Barra do Una, São Sebastião. Créditos: Douglas Scaramussa Pereira

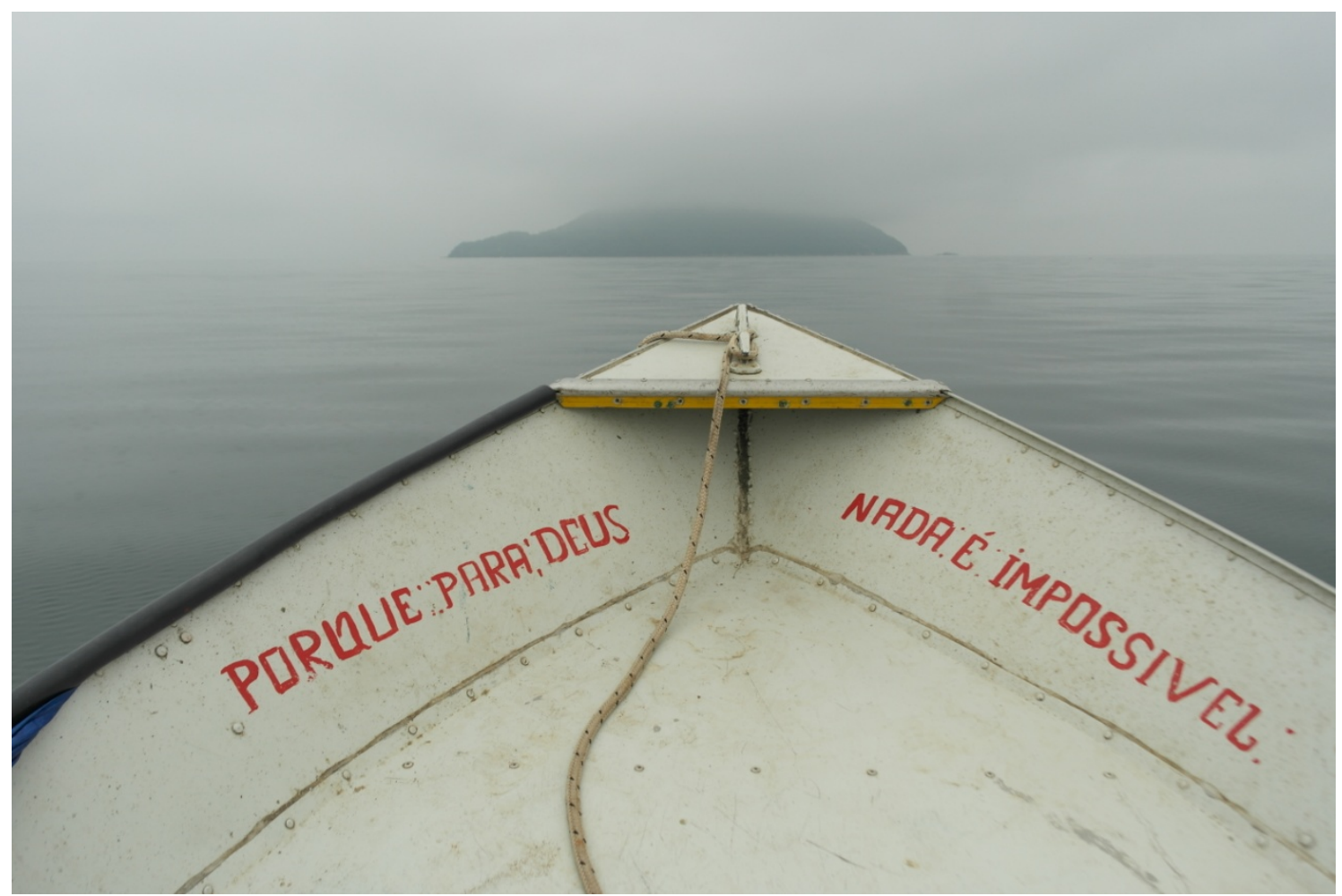

Figura 52. Fotografia da ilha Monte de Trigo vista do barco que usamos na travessia partindo da Barra do Una. Créditos: Douglas Scaramussa Pereira 


\section{Topônimos e lugares notáveis}

Preliminarmente, em termos direcionais, quer dizer, no que tange à situação das massas terrais umas em relação às outras, é praticável discriminar uma costa voltada ao continente, o mar noroeste, e, diametralmente oposta a ela, um costão íngreme ladeado pelo mar grosso, para bem valer-se da terminologia monteira. Partindo-se, pois, deste ponto de mar aberto e de acentuado desnível litorâneo e seguindo-se em sentido anti-horário, tem-se, a nordeste, a Ponta Negra (dada a maficidade de sua constituição rochosa); ao norte, o Porto do Imbiru (sutil reentrância costeira do mar abrigado, opondo-se às correntes marítima e de vento do sul, típicas do mar bravo); a noroeste, as Tocas (escolhos e lajeados marinhos, com destaque para a Lage, de maior dimensão); a oeste, costão pouco articulado; e, enfim, ao sul, as ilhotas e a Ponta do Sul (sendo esta uma saliência entre duas reentrâncias, uma a ocidente, Itapeva, e outra a oriente, Leme $)^{253}$.

Afora as articulações da costa, há acidentes tanto na linha vertical quanto no interior insular que merecem exame acurado nesta etapa de caracterização inicial. Quem, de súbito, apreciar as curvas de nível da ilha, mesmo que com equidistância insatisfatória para a escala de análise ${ }^{254}$, não terá alternativa senão notar um terreno íngreme a sudoeste quando contrastado com o nordeste mais habitado, o Platô da Vila dos Pescadores. Por configuração fisiográfica que lhe é característica, o sopé da vertente setentrional do morro impõe-se como terreno irregular - sulcado, constitui também referência por abrigar as Cavernas e a Toca da Caveira. O pico, com seus $289 \mathrm{~m}$, abriga uma torre de transmissão de sinal.

No que tange às localidades, há uma a noroeste, de relevância pretérita, e uma a nordeste, centro humano da atualidade. A primeira, o Sítio de Fora, não constitui, a rigor, uma localidade, por não dispor de uma aglomeração humana permanente. Há apenas uma construção, com a Capela de São Benedito. Já o segundo, a Vila dos Pescadores, tem a oferecer habitações, uma escola com roçado, caixas d'água, uma ponte, uma igreja, um campo de futebol (ponto de reunião masculina por excelência) e plantações de cana-de-açúcar. Nesta povoação, entre as trilhas para o Pico e o Sítio de Lá, destacam-se dois pontos referenciais, a Pedra do 13 (onde há mudança de código de área da telefonia móvel) e a ponte sobre o rio Pardo, um dos riachos ou regatos que correm vertente abaixo em direção ao mar.

253 Ibidem, p. 244-245

254 Ibidem, p. 244 


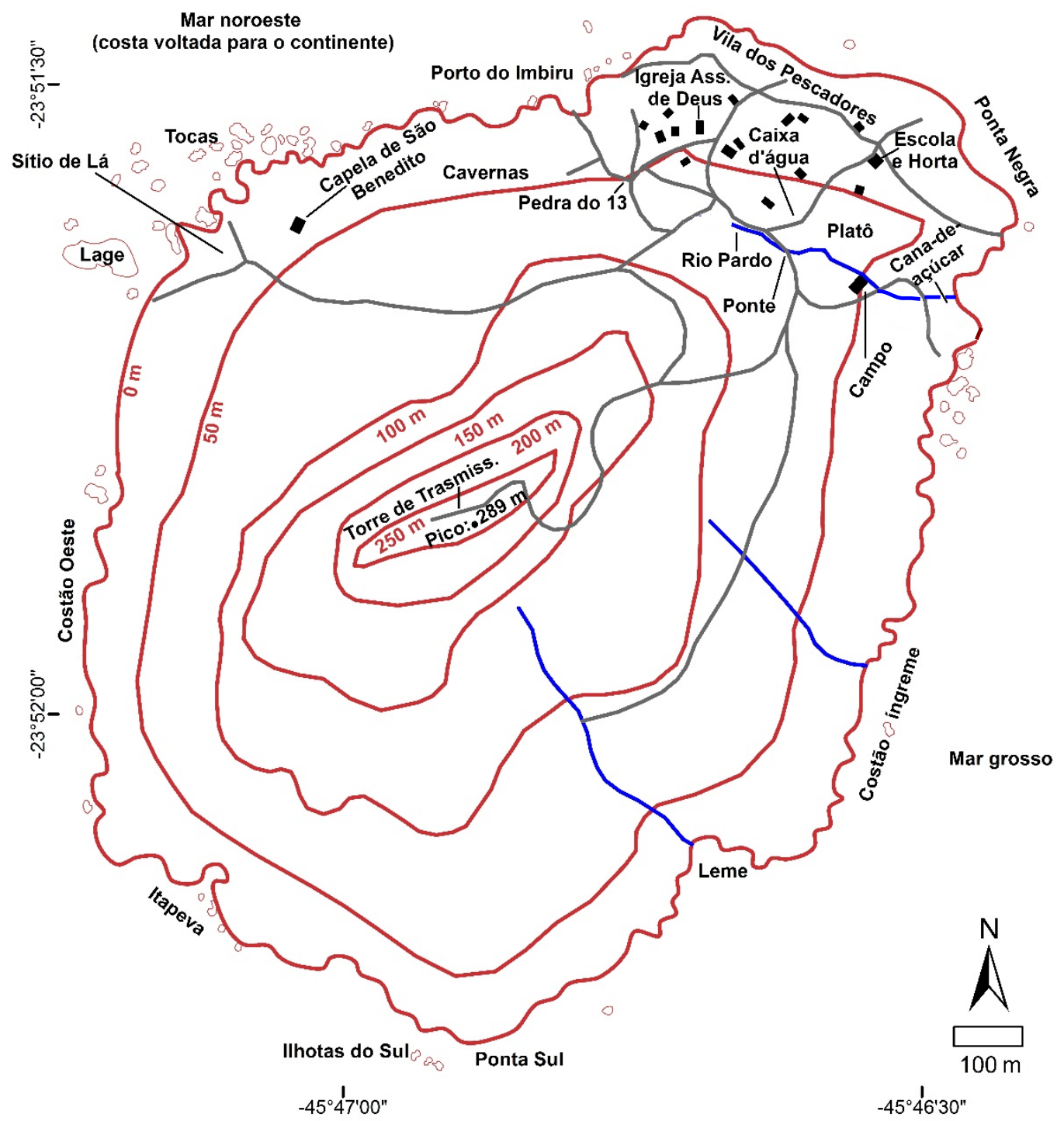

PLANIALTIMETRIA DE REFERÊNCIA

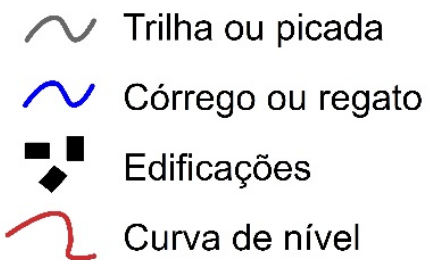

Elaboração: Menegatto, 2017

referência: Ortofotos - Emplasa (2011)

Fonte: Coutinho e Melcher (1973)

Alguns topônimos levantados em campo

Figura 53. Mapa planialtimétrico de Monte de Trigo 


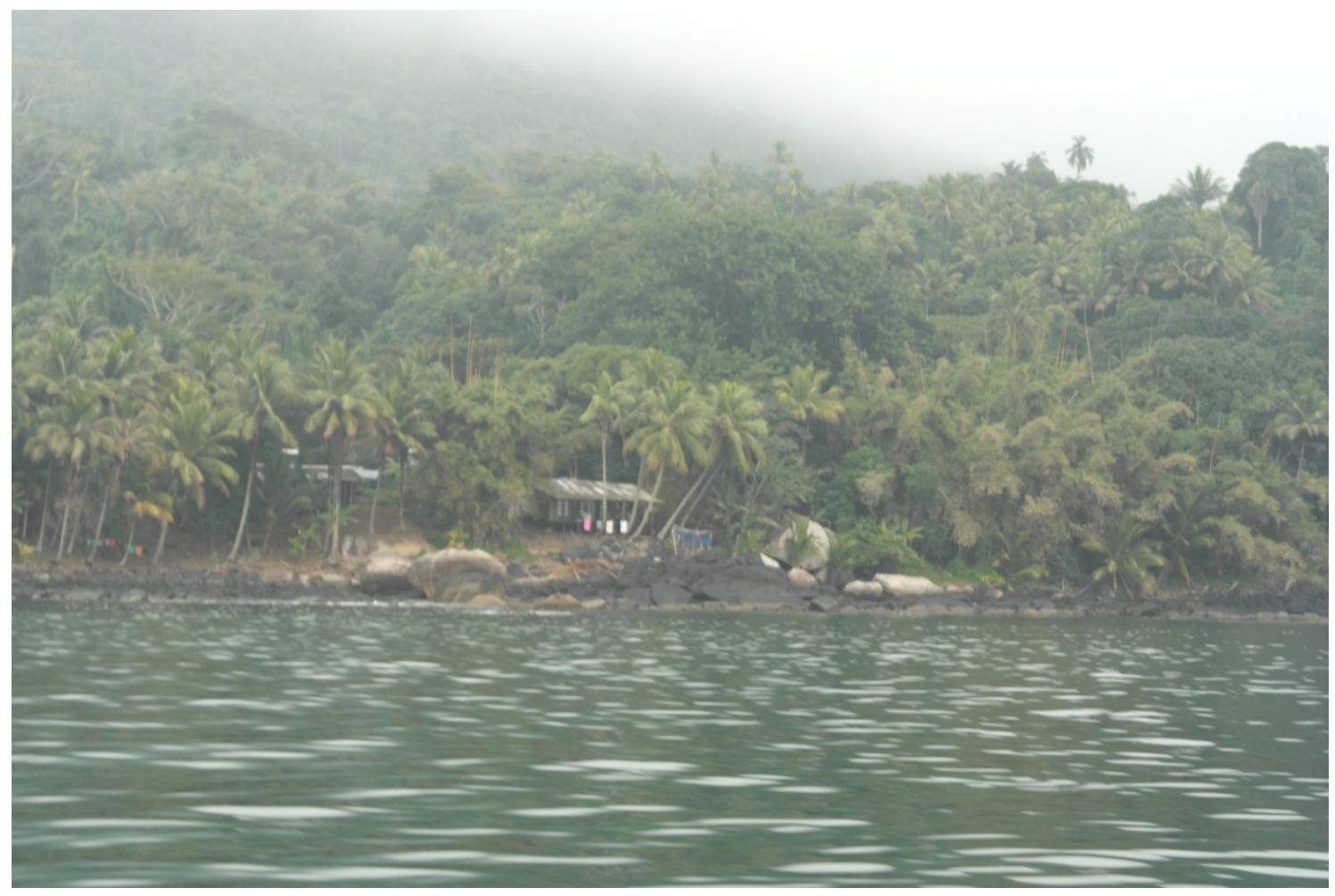

Figura 54. Fotografia da Vila dos Pescadores, localizada no platô. Créditos: Douglas Scaramussa Pereira

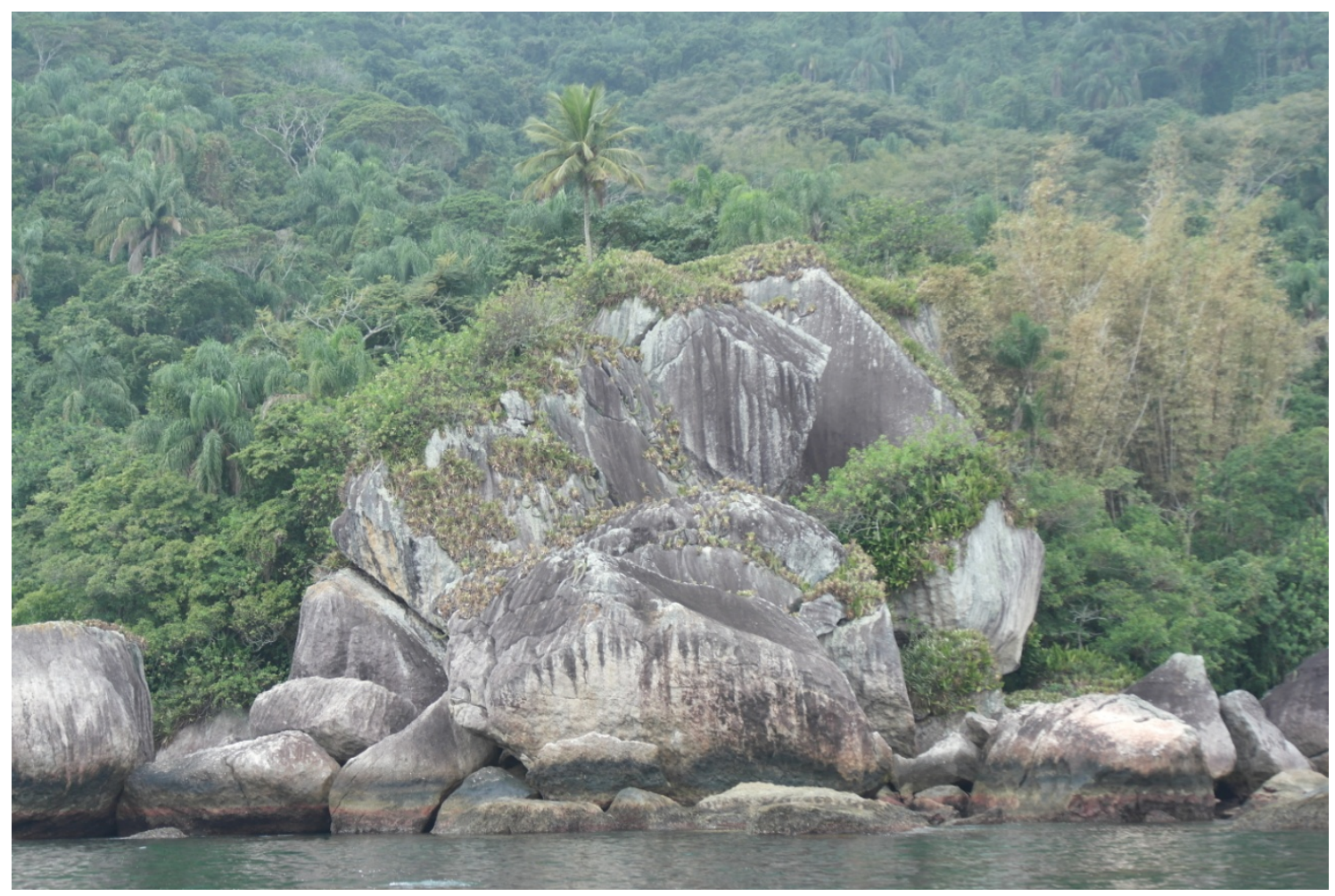

Figura 55. Fotografia do ponto de atracamento no Sítio de Lá. Créditos: Douglas Scaramussa Pereira 


\section{Retrato geológico-geomorfológico}

Posicionada, do ponto de vista morfoestrutural e tectônico, na Província da Serra do Mar, despontando como terra de gênese magmática, a realidade insular em questão é uma suíte alcalina do Cretáceo e do Terciário ${ }^{255}$. Com efeito, esse tipo de magmatismo confere-lhe peculiaridade. “Ao contrário do magmatismo toleítico, presente em grandes volumes, como derrames, exames de diques e sills, o magmatismo alcalino e carbonático está presente como pequenas ocorrências pontuais" ${ }^{256}$. Eis o caso do Montão. E, nessa condição, partilha de características geoquímicas similares às de outras ilhas oceânicas de origem e localização relativamente próximas, como Vitória, Búzios e São Sebastião ${ }^{257}$.

Se empreendermos uma história geológica de Monte de Trigo, teremos a ocorrência de vários pulsos magmáticos de natureza distinta, com intrusão do embasamento granítico-gnáissico da Faixa Ribeira. A gênese insular está, pois, relacionada aos demais corpos alcalinos vizinhos contemporâneos (outras ilhas do entorno), ao longo de falhamentos regionais. Veja-se, a valer, a pujante influência da tectônica regional. De seu partido, o principal mecanismo de evolução magmática parece ter sido a cristalização fracionada, evidenciada pelas estratificações e pela litodiversidade (de melanocrática a ultramáfica). Ora, caso se estabeleça uma sequência de cristalização do magma, tenha-se, nessa ordem, a olivina e o piroxênio; a magnetita; o plagioclásio associado às fatias marginais do piroxênio; a biotita e o anfibólio intersticiais, juntamente aos feldspatos; e, finalmente, a nefelina. Acrescente-se, para além, que os minerais máficos acumularam-se cada qual a seu modo na base da câmara magmática ${ }^{258}$.

Estudos geocronológicos sugerem, por meio de datação isotópica $40 \mathrm{Ar} / 39 \mathrm{Ar}^{259}$, que as rochas monteiras acumulam 86,5 milhões de anos de existência ${ }^{260}$. Nesse tempo, marcam-se cinco fases do magmatismo insular: a primeira, máfica e ultramáfica intrusiva; a segunda, um pipe de brecha magmática; a terceira, a existência de nefelina sienítica intrusiva; a quarta, a ocorrência de diques de lamprófilos a fonólitos; e a última, fatos finais associados ao recuo erosivo da Serra do $\operatorname{Mar}^{261}$.

255 HEILBRON et. al., 2004 apud ENRICH ROJAS, 2006, p. 27

256 ALMEIDA, 1983 apud ENRICH ROJAS, 2006, p. 26

257 SPINELLI, 2007, p. 5

258 ENRICH ROJAS, 2006, p. 42

259 A datação deu-se, como se vê, pela análise do decaimento radioativo de isótopos de argônio (Ar), muito comuns para esse tipo de investigação.

260 Ibidem, p. 48

261 Ibidem, p. 27, 45 


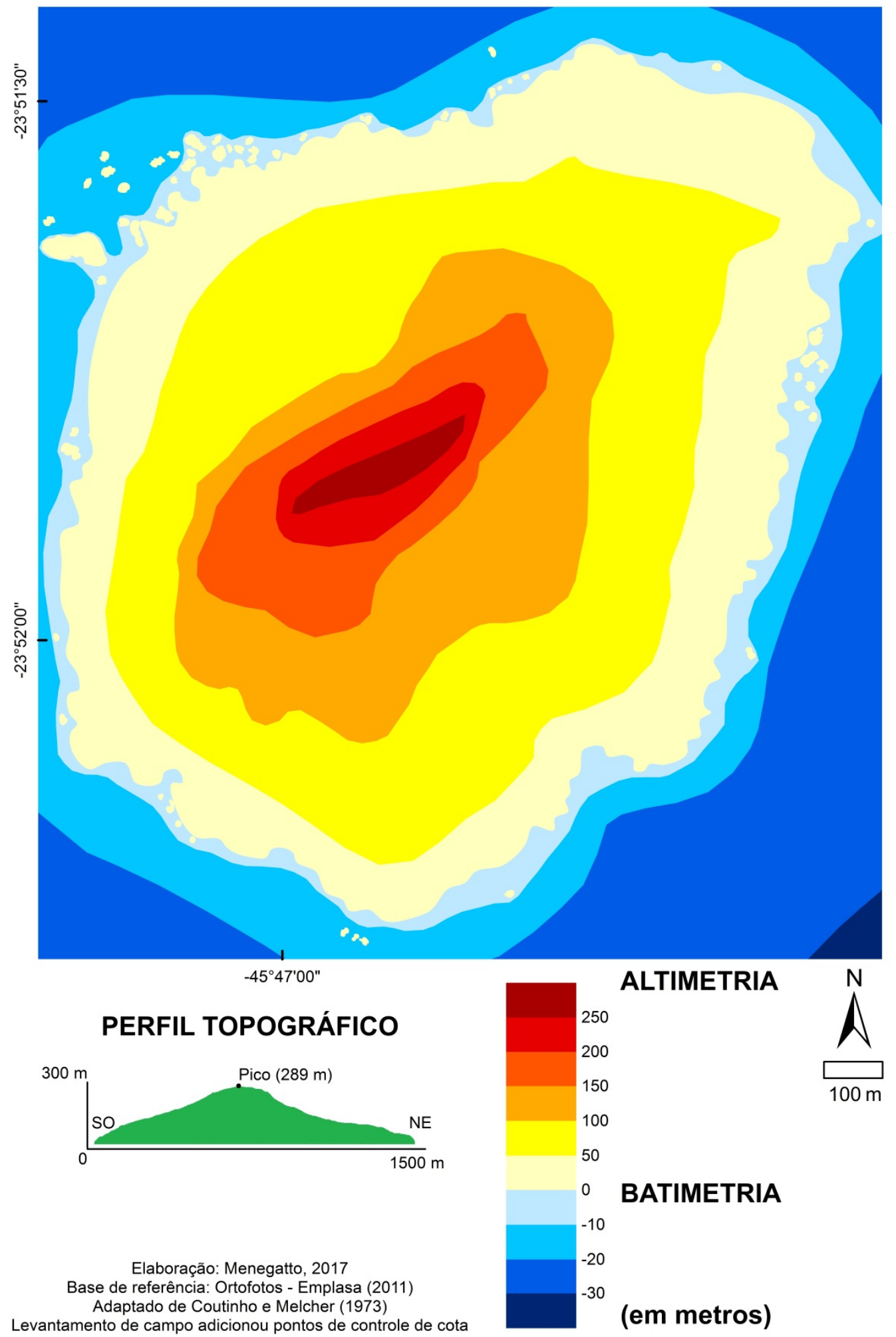

Figura 56. Mapa orobatimétrico e perfil topográfico de Monte de Trigo 
Investigações científicas pioneiras segmentaram o terreno monteiro em dois domínios plutônicos contrastantes: os teralitos, melanocráticos, a nordeste (Ponta Negra), e os foiaítos, leucocráticos, na parcela centro-meridional. No que tange à sua área total de ocorrência, os primeiros ocupariam apenas $12 \%$, enquanto os segundos, $88 \%{ }^{262}$. Acompanham essa matriz teralítico-foiaítica numerosos diques posteriores com brechas vulcânicas e outras rochas compostas de minerais ora félsicos, ora máficos ${ }^{263}$.

Ulteriormente, numa combinação de análise de campo e laboratório, derivou-se uma Cartografia geológica mais precisa do espaço monteiro. Neste, as rochas plutônicas ramificam-se em quatro domínios petrográficos distintos ${ }^{264}: 1$. Sienítico ( $90 \%$ da área), representado por um stock, zonado quanto à saturação em sílica de modo a abranger tanto a nefelina sienito I, no centro geométrico insular, quanto a nefelina sienito II e o sienito com nefelina, nas áreas marginais. 2. Monzossienítico, em delgada fração sudeste. 3. Máfico, o segundo em área de ocorrência (7\% do total), constituído por melateralitos e olivina melagabros com nefelina. 4. Ultramáfico, no extremo boreal, ladeado pelo setor máfico e com representatividade inferior à dele, com exemplares de clinopiroxenitos e olivina clinopiroxenitos.

Ora, uma vez examinada sua Geologia, parece possível inferir algo sobre sua Geomorfologia. Comece-se pela forma elíptica que lhe é característica e pelas diferenças altimétricas pronunciadas e sirva-se desses fatos para voltar-se em direção aos compartimentos do relevo dessa terra emersa. De fato, a importância dessa regionalização está na própria referência que determinadas unidades de terreno assumem no contexto dos lugares. No caso específico das ilhas alcalino-sieníticas, aliás, tendem a ser "marcantes na paisagem, pois são geralmente de amplitude altitudinal maior do que as ilhas graníticas e têm formas cônicas, lembrando antigos vulcões - como Monte de Trigo e Ilha de São Sebastião - ou formam um conjunto de pães-deaçúcar, como Alcatrazes"265.

Para efeitos de contextualização inicial, é necessário afirmar que, tanto é o caso de Montão de Trigo como de outras ilhas de mesmo âmbito regional, o relevo geral do litoral norte paulista é bastante dissecado, com drenagem dendrítica (adaptada às direções das estruturas relacionadas a fraturas, falhamentos e contatos litológicos) e alta declividade de vertentes, com nível de fragilidade potencial elevado (sujeição, inclusive, a processos erosivos pluviais agressivos e a movimentos de massa $)^{266}$.

262 COUTINHO e MELCHER, Op. cit., p. 245

263 MOTOKI, 1986, p. 11

264 ENRICH ROJAS, 2000 , p. 22-23

265 SARTORELLO, Op. cit., p. 14.

266 ROSS, 1997 apud SARTORELLO, Op. cit., p. 15 


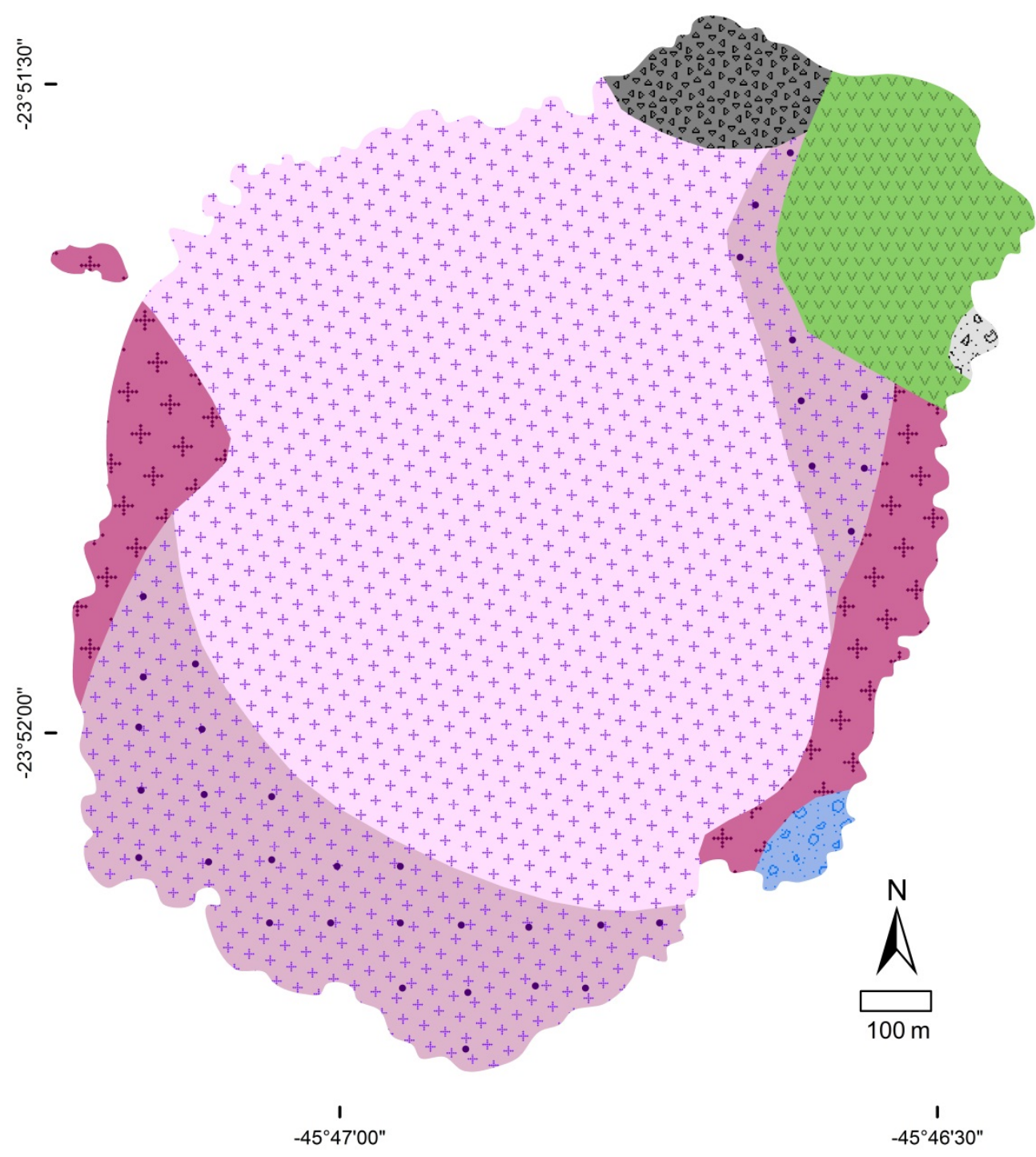

LITOLOGIAS

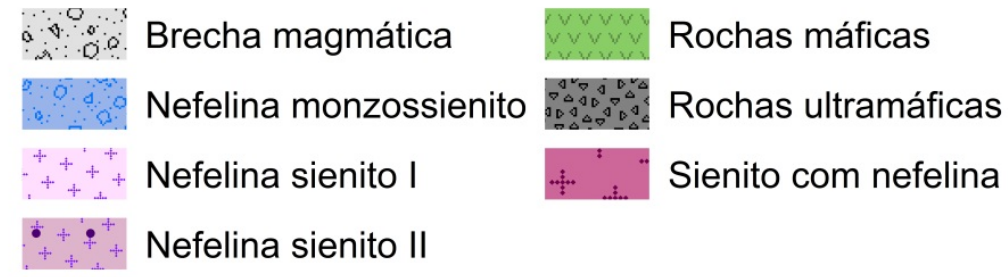

Elaboração: Menegatto, 2017 Adaptado de Enrich Rojas (2000)

Figura 57. Mapa litológico de Monte de Trigo. Adaptação: Enrich Rojas (2000)

Ademais, não apenas praticável é a compartimentação litológica do espaço monteiro, como também são nele discerníveis algumas unidades fisiográficas. Adentrando-se o costão rochoso, há rochas com direções de diáclase produzidas por "mecanismo de resfriamento geometricamente 
condicionado à forma do maciço" 267 . Os matacões de sopé e média vertente abundam na medida em que o gradiente topográfico médio de $48 \%$ desencadeia um contínuo processo de deposição gravitacional $^{268}$. Os sedimentos são grosseiros, não havendo quaisquer praias arenosas ou pontos com volume avantajado de aluviões finos.

Com $300 \mathrm{~m}$ por $600 \mathrm{~m}$, há um platô de aspecto melânico ao norte, particularizado em relação ao maciço mais austral. Sua declividade relativamente mais módica é, sem titubear, fator de fixação populacional. No maciço, há um costão oriental bastante íngreme e um costão ocidental repleto de blocos decamétricos empilhados (constituidores daquilo que os habitantes locais denominam "cavernas") ${ }^{269}$. Não fosse a exuberância da cobertura vegetal, as rochas expostas seriam o distintivo do espaço monteiro. A valer, o topo insinua-se com paredão adjacente mais declivoso que a média do conjunto insular, tendo-se, em paralelo, nas cotas altimétricas inferiores, uma exposição esparsa de lajes segundo uma franja litoral de articulação mediana, postos os minerais resistatos que se combinam em sua litologia. Enfim, é notório o fato de o terreno, eleja-se uma encosta do maciço em qualquer direção, ser entrecortado por blocos dispersos (em isolado, nos setores mais retilíneos; combinados, nas parcelas de maior concavidade).

Comparando o inventário arrolado e os mapas altimétrico ${ }^{270}$ e geológico ${ }^{271}$ de Monte de Trigo, individualizam-se, do ponto de vista da análise geomófica em escalas de maior detalhe, dois conjuntos de unidades. De um lado, as formas da vertente, e, de outro, os afloramentos de rocha nua. $\mathrm{O}$ item antecedente apresenta, de sua parte, uma baixa vertente com blocos fragmentados a nor-noroeste; uma vertente convexa floresta com desnível acentuado na latitude mediana, ao redor do pontão do maciço principal; e uma vertente, também convexa florestada, com desnível abrupto na porção centro-austral. O consequente, por sua vez, é representado pelas tocas aquáticas (escolhos de pequenas dimensões e lajeado marinho de área mais avantajada), pelo costão rochoso e pelo penedo de topo aguçado (pontão). Neste final, como é de se esperar, a linha de cumeada desenvolve-se segundo o eixo maior da elipse monteira. São, ainda, diferenciáveis outras duas áreas: uma forma baixa medianamente tabuliforme, ao norte, na Vila dos Pescadores, constituindose, na verdade, um prolongamento do maciço magmático central; e uma forma de dissecação na vertente oriental, resultante de erosão hídrica de fluxo linear (como é característico do sistema encosta).

267 COUTINHO e MELCHER, Op. cit., p. 244-245

268 Idem, loc. cit.

269 ENRICH ROJAS, 2006, p. 1-5

270 COUTINHO e MELCHER, loc. cit.

271 ENRICH ROJAS, 2000, p. 23 

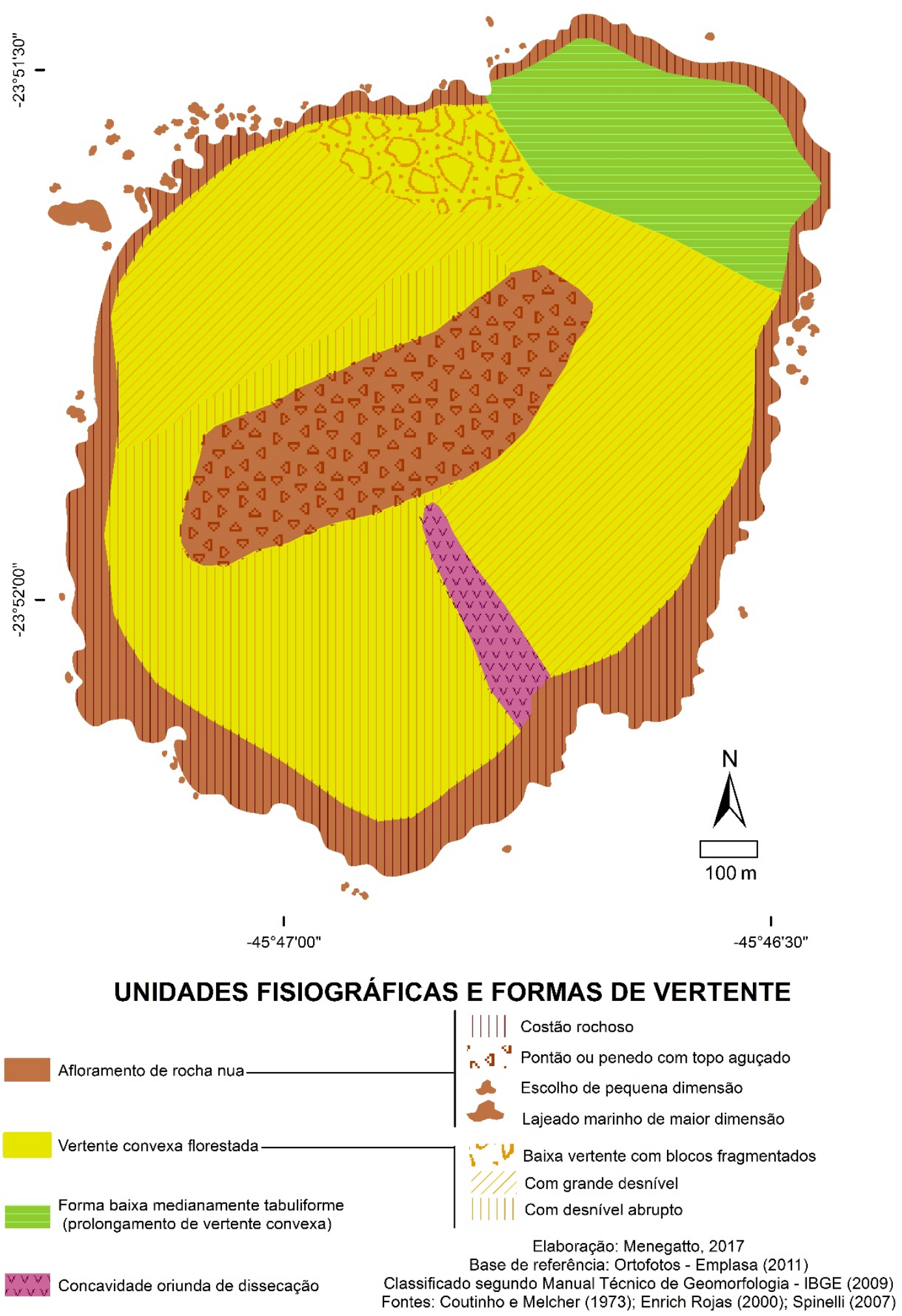

Figura 58. Mapa de unidades fisiográficas e formas de vertente de Monte de Trigo 


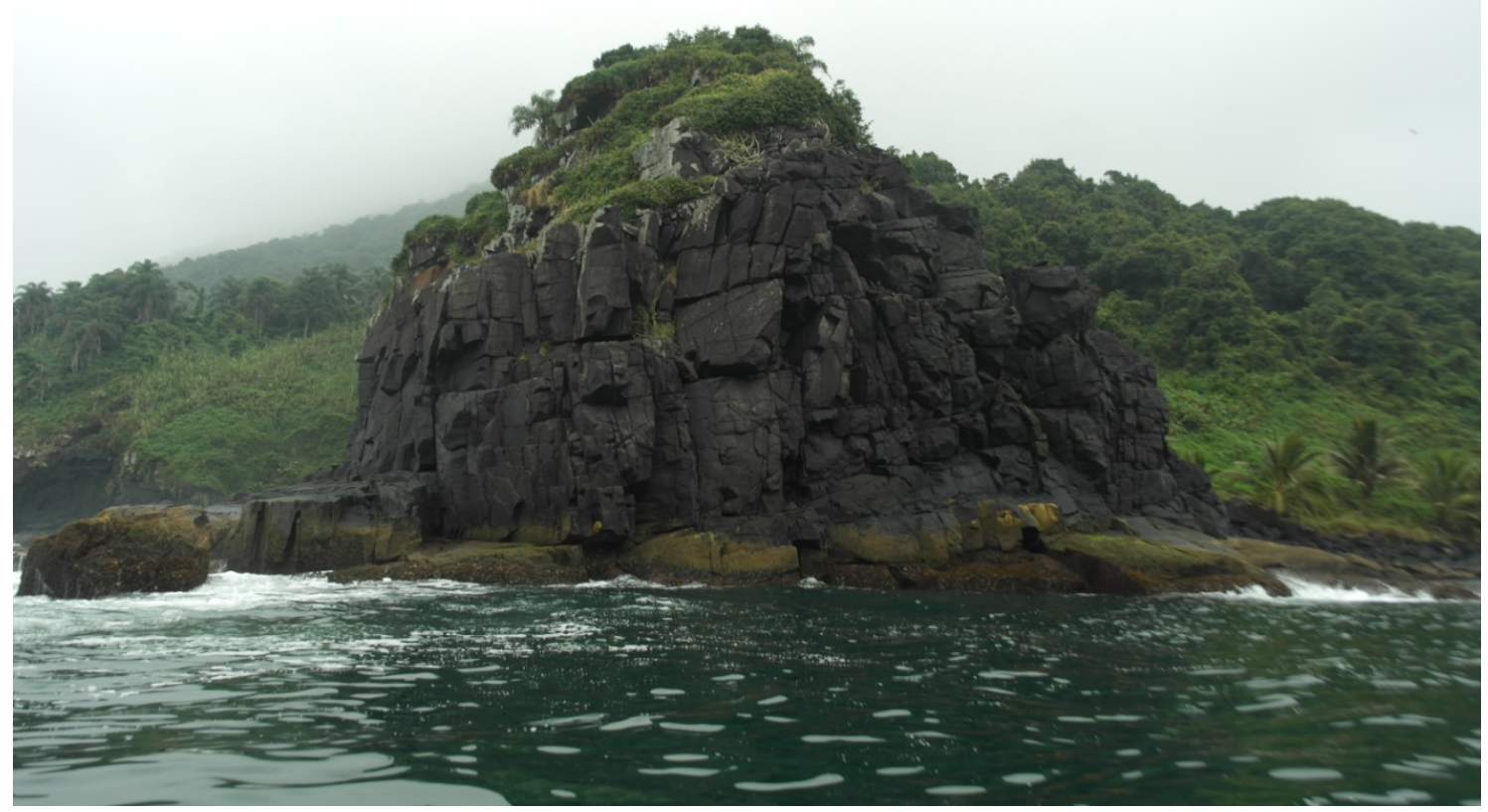

Figura 59. Fotografia da Ponta Negra. Créditos: Douglas Scaramussa Pereira

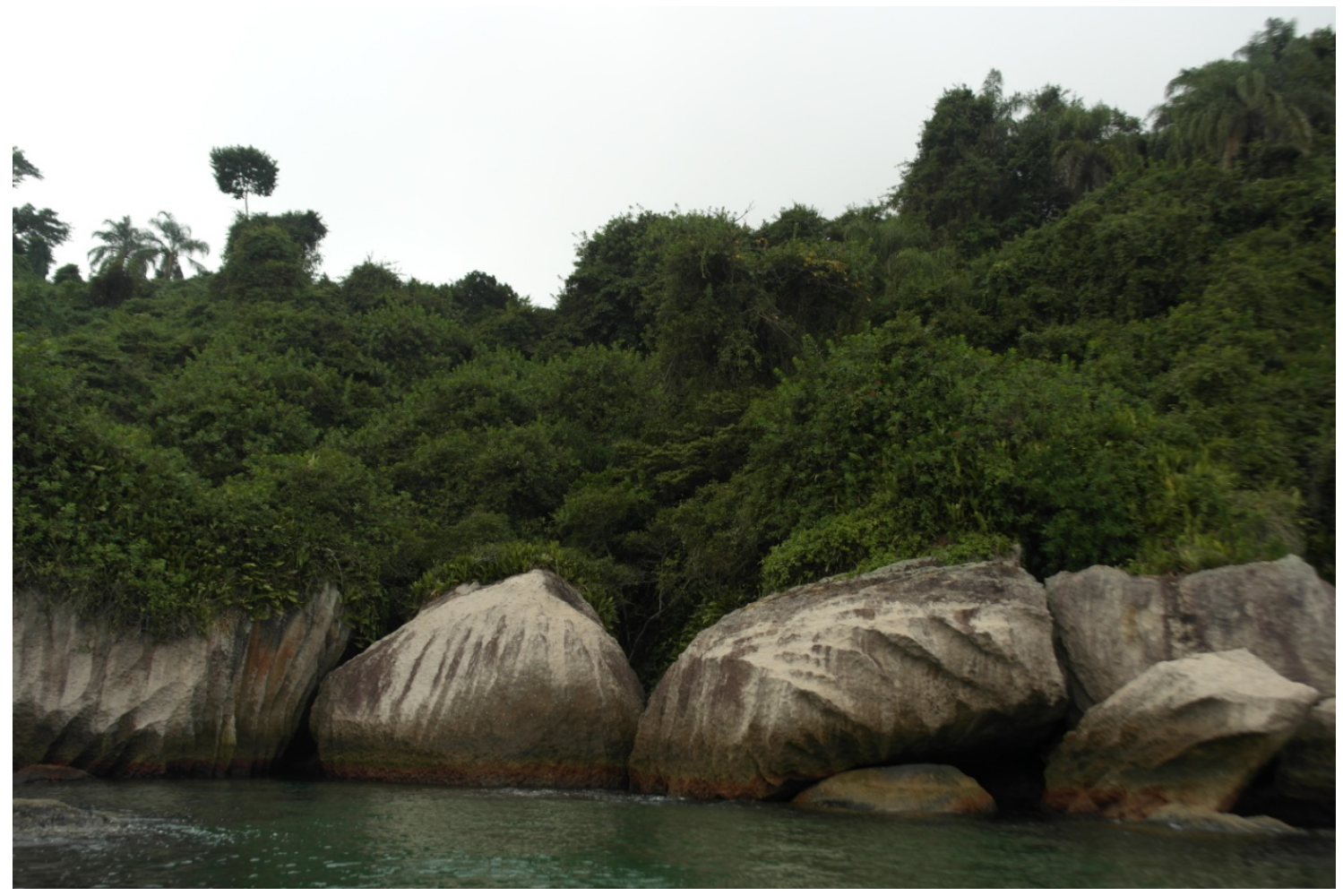

Figura 60. Fotografia de escolhos próximos ao costão das Tocas. Créditos: Douglas Scaramussa Pereira 


\section{Ambientes topoclimáticos}

Empregando-se a classificação climática de Köppen ${ }^{272}$, o clima do litoral norte paulita define-se caracteristicamente como tropical, com precipitação média anual superior a $1.500 \mathrm{~mm}$, total de chuvas do mês mais seco superior a $60 \mathrm{~mm}$, temperatura média do mês mais frio superior a $18^{\circ} \mathrm{C}$, sem estação invernal bem definida e com verões, como é frequente, excessivamente úmidos. De mais a mais, a zona onde se localiza Monte de Trigo é típica de transição de sistemas atmosféricos, com grandes oscilações ao longo dos anos, amplitude térmica diária mais ou menos acentuada (por vezes, abrandada pela maritimidade), vento predominante de sudeste, período chuvoso (valores de até $2.000 \mathrm{~mm}$ ) de outubro a março e período mais seco (totais mais baixos, porém normalmente acima de $1.000 \mathrm{mmm}$ ) de abril a setembro ${ }^{273}$.

Ademais, a distribuição das precipitações vale-se tanto da maritimidade quanto do efeito orográfico da Serra do Mar e da dinâmica das frentes ${ }^{274}$. Comprova-se, o sistema oceano-atmosfera é a base do clima insular e, no caso das terras monteiras, ocorre por meio dos embates entre a massa polar e a massa tropical atlânticas, bem como segundo o regime atmosférico desempenhado pelo Anticiclone e, principalmente, pela Zona de Convergência do Atlântico Sul. No caso do Montão, dada sua localização junto às isóbatas menos profundas da costa, os aspectos oceanográficos da Plataforma Continental de Sudeste (PCSE) tendem a influenciar o clima, bem como a sofrer suas influências diretas. A valer, "os movimentos das águas na PCSE são gerados por uma combinação de diferentes forçantes, tais como a Corrente do Brasil, as marés, os ventos e as descargas fluviais" 275. Ademais, a penetração dos ventos úmidos no terreno dos monteiros depende sobremaneira da circulação e da mistura sazonal das Águas Tropical (com maior salinidade e temperatura geralmente acima de $20^{\circ} \mathrm{C}$ ), Costeira (menor salinidade devido à descarga dos rios no continente, com maior pujança no inverno) e do Atlântico Sul (menor temperatura e salinidade, impõe-se à camada mais subsuperficial da plataforma, notadamente no verão) ${ }^{276}$.

Se, aos fatores climáticos apontados, somarmos a ação dos nevoeiros, que, em Montão de Trigo, tem participação mais evidente no pico rochoso aguçado, relativamente mais frio que o costão, torna-se factível meditar sobre possíveis ambientes topoclimáticos na ilha. Naturalmente, extrapole-se a distinção higroscópica entre pico e cotas mais modestas, há que se reconhecer outras duas regiões: a vertente do mar bravo e a vertente do mar abrigado, sendo a primeira comparativamente mais úmida que a segunda.

272 SARTORELLO, Op. cit., p. 11

273 MONTEIRO, 1973, 1976 apud SARTORELLO, loc. cit.

274 SCHRODER, 1956 apud SARTORELLO, loc. cit.

275 MAZZINI, 2009, p. 3

276 Ibidem, p. 5 


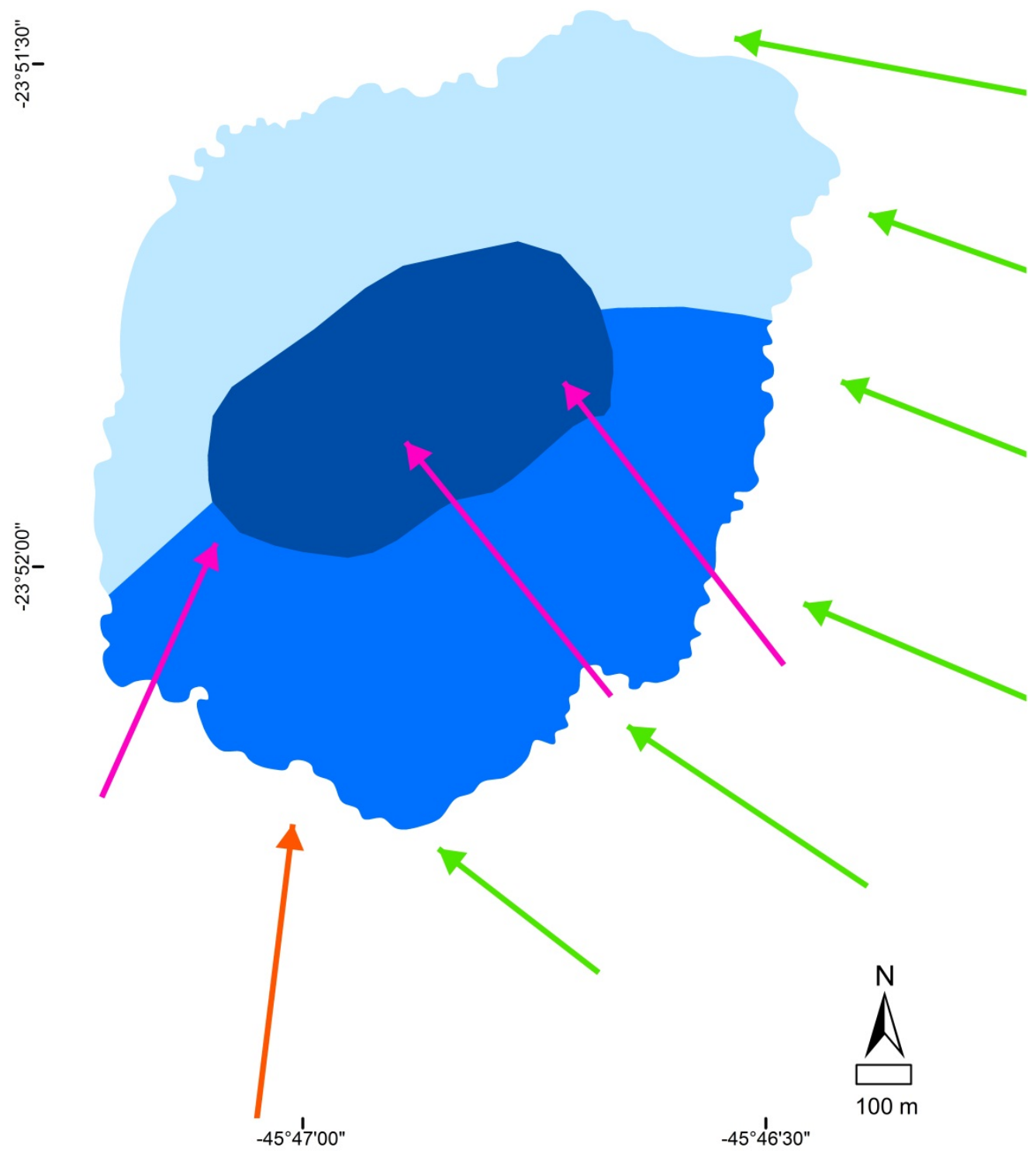

Unidades Topoclimáticas Condicionantes geográficos

Pico úmido
Vertentes do mar bravo
Vertentes mais abrigadas

Elaboração: Menegatto, 2017

Base de referência: Ortofotos - Emplasa (2011) Fontes: Mazzini (2009), Sartorello (2010)
Corrente de leste (normal à costa)

$\longrightarrow$ Fluxo de ascenção higroscópica

Fluxo da Água Tropical e da Água Central do Atlântico Sul na Plataforma Continental de Sudeste (influência atenuada da Corrente do Brasil)

Figura 61. Croqui climático esquemático de Monte de Trigo 


\section{A natureza como recurso}

Ora, se intrínseca é a relação atmosfera-oceano, também é de se analisar a existência ou não de um nexo entre clima e águas interiores. Decerto, o clima tropical úmido, quando combinado com uma suíte alcalina como a de Montão de Trigo, é capaz de ensejar uma série de fluxos hídricos vertente abaixo, alguns deles formando verdadeiramente riachos ou, até mesmo, regatos coincidentemente às concavidades de dissecação. A alta declividade, a área diminuta insular e a resistência do leito rochoso não permitem, a sério, a formação de um rio de maior caudal ou hierarquicamente mais significativo, apesar de figurarem nomes como "rio Pardo" na Vila dos Pescadores. Algumas dessas águas interiores, por seu lado, localizam-se na vertente do mar bravo e próximo ao costão austral. Um olhar atento a uma ortofotografia ${ }^{277}$ ou a uma carta planialtimétrica $^{278}$ permite distinguir com facilidade um entalhamento fluvial com foz próxima ao Leme.

Pesquisas de campo anteriores apontaram a existência de sete nascentes em média vertente $^{279}$, donde despontam cursos d'água de baixa vazão, com destaque para o córrego do Rio Pardo, mais setentrional ${ }^{280}$. Por sua vez, os moradores servem-se das águas de nascentes localizadas nas áreas mais elevadas, utilizando-se, para tal, de trilhas de difícil acesso e manutenção, algumas, inclusive, voltadas para a vertente oriental. Os monteiros também se valem de mangueiras conectadas diretamente nesses pontos de início de drenagem, bem como de caixas d'água em suas residências $^{281}$.

Frutos do clima úmido, orientando-se segundo a gravidade oferecida pelo relevo, a despeito de seus obstáculos, os recursos hídricos, uma vez perenes, permitiram a colonização permanente da ilha. A luz solar, dadivosamente oferecida num contexto de tropicalidade, não é recurso menos importante: precisamente, a energia elétrica utilizada é de matriz fotovoltaica. A fonte dá-se por painéis solares acionados por baterias de carro, e, posto o fato de não haver outra opção existente, faz-se imperioso ter em uso apenas equipamentos de baixo consumo (televisores, rádios, carregadores de celular), excluindo-se, assim, geladeiras e chuveiros elétricos, que requerem maiores níveis de eletricidade ${ }^{282}$.

277 Ortofotos gentilmente cedidas pela Empresa Paulista de Planejamento Metropolitano S.A. (Emplasa)

278 Há a folha topográfica SF-23-Y-D-V-1 (Salesópolis). É também possível consultar COUTINHO e MELCHER, Op. cit., p. 244.

279 CARDOSO, 1996, p. 37

280 CAROLINO, 2010, p. 45

281 PEREIRA et al., Op. cit., p. 32

282 CAROLINO, Op. cit., p. 58 


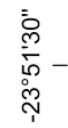

啇

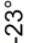

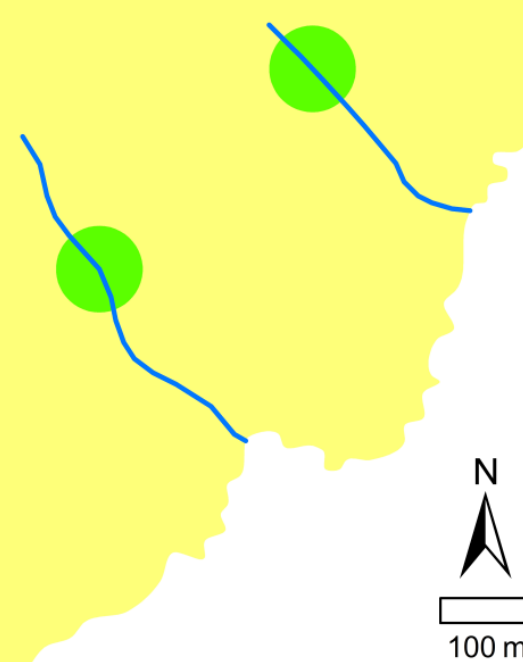

$\frac{1}{-45^{\circ} 47^{\prime} 00^{\prime \prime}}$

।
$-45^{\circ} 46^{\prime} 30^{\prime \prime}$

\section{ABASTECIMENTO DE ÁGUA E ENERGIA ELÉTRICA}

Abastecimento de água
Paineis fotovoltaicos
$\sim$ Córrego ou regato confirmado

Elaboração: Menegatto, 2017 Base de referência: Ortofotos - Emplasa (2011)

Figura 62. Mapa de abastecimento de água e energia elétrica em Monte de Trigo 


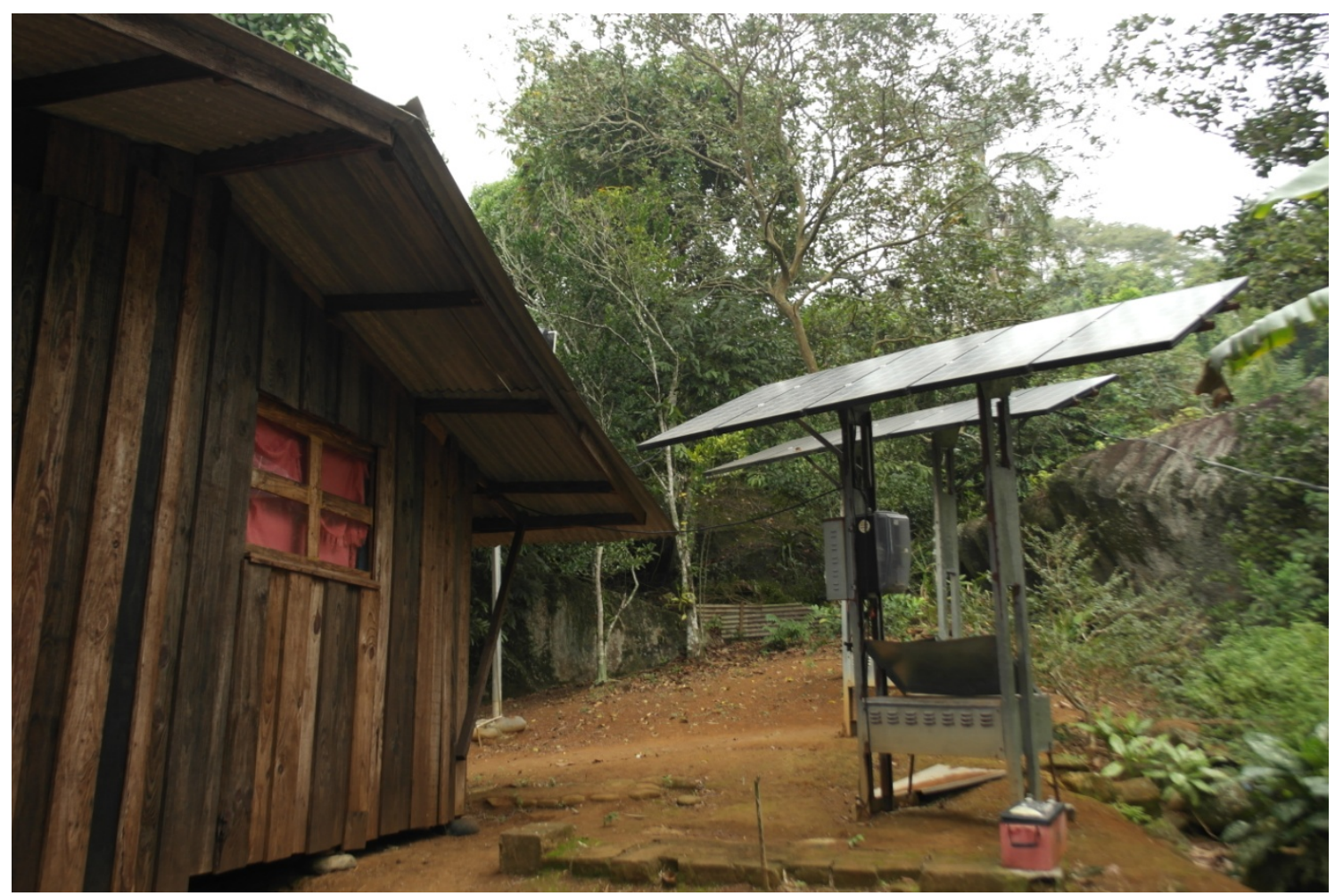

Figura 63. Fotografia de painel fotovoltaico na Vila dos Pescadores. Créditos: Douglas Scaramussa Pereira

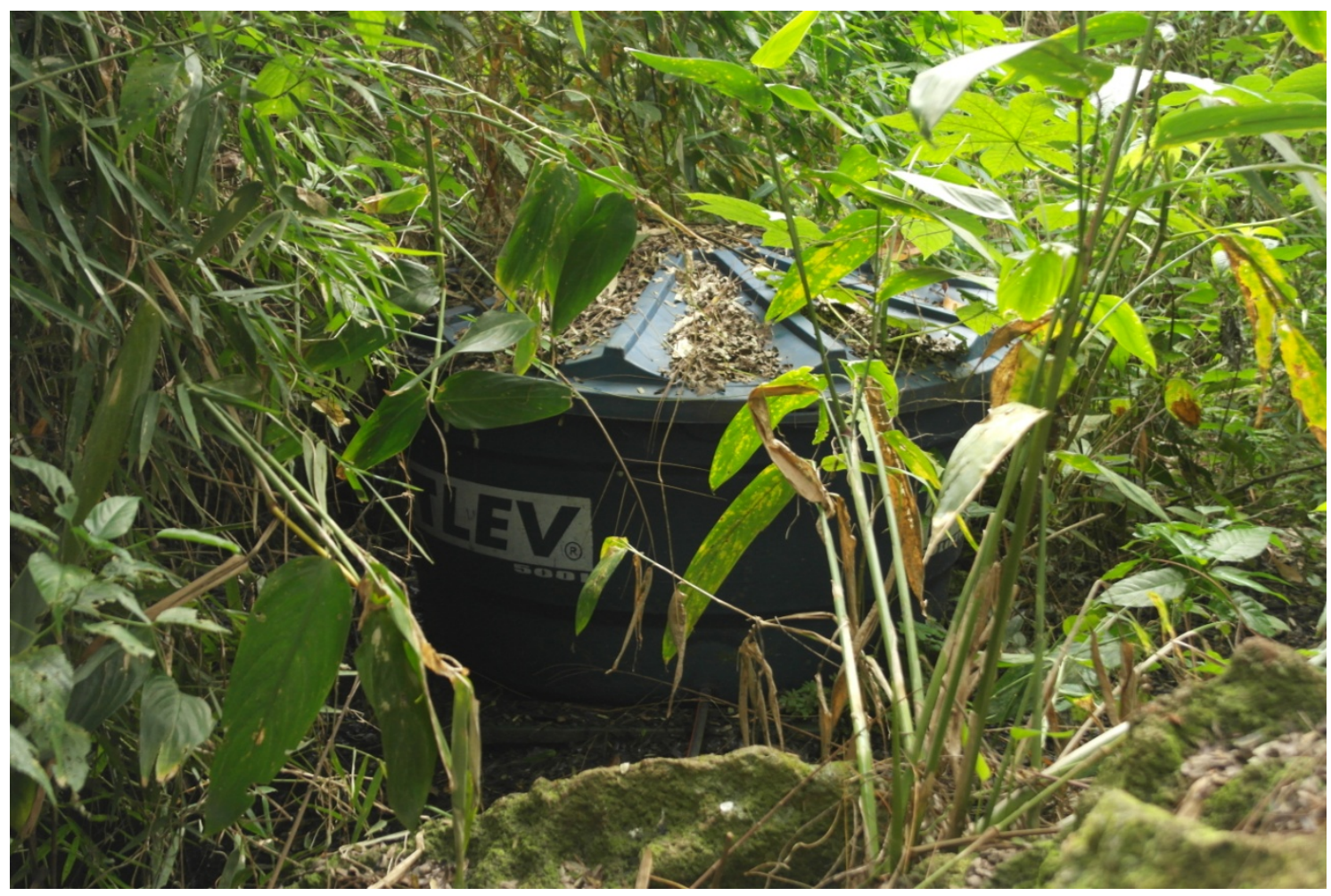

Figura 64. Fotografia de caixa d'água na Vila dos Pescadores. Créditos: Douglas Scaramussa Pereira 


\section{Solos e afloramentos rochosos}

Na condição de ilha alcalino-sienítica, a paisagem monteira está, a exemplo de seu contexto geral, marcada por depósitos de piemonte e de encosta, representados por materiais rudáceos de tálus e colúvio ${ }^{283}$. De mais a mais, como já se viu, abundam afloramentos rochosos por toda parte, tanto em termos de campos de matacões em altas e médias vertentes, como em termos de blocos decamétricos empilhados em baixa vertente a nor-noroeste, como, ainda, em áreas lajeadas da costeira e do pontão na cumeada ${ }^{284}$. De seu lado, a orientação subvertical das vertentes e do costão, combinada ao considerável gradiente topográfico e à resistência das rochas à intemperização, oferta, como consequência imediata, solos aparentemente rasos e cobertos por matacões ${ }^{285}$.

Como em outras ilhas similares ${ }^{286}$, é possível inferir a existência de cambissolos e, nos trechos de encosta mais íngremes, tais quais o centro-meridional e o oriental de baixa altitude, neossolos litólicos, já circundantes aos afloramentos de rocha nua. No primeiro tipo de solo, há um horizonte de perdas de argilas, ferro e alumínio (A) assentado sobre um horizonte de acumulação incipiente (Bi), sendo todo o perfil pedregoso. De seu lado, a segunda classe pedológica caracterizase pela minguada espessura, pela alta rochosidade e, de fato, pela inexistência de um verdadeiro horizonte de acumulação $(\mathrm{B})^{287}$.

A paisagem monteira, apesar desse cenário pedológico, dada a umidade climática e os minerais ofertados pelo magmatismo, é caracteristicamente marcada por florestamentos introduzidos, com espécimes frutíferas, em contraste com uma "vegetação do tipo floresta tropical úmida", que "se desenvolve de modo exuberante nas encostas da face sul e em alguns cílios de vale, na metade norte da ilha" ${ }^{288}$.

283 SARTORELLO, Op. cit., p. 14 284 ENRICH ROJAS, 2000, p. 1-5 285 CARDOSO, 1996, p. 37 286 SARTORELLO, Op. cit., p. 15

287 Segundo critérios do Sistema Brasileiro de Classificação de Solos, da Empresa Brasileira de Pesquisa Agropecuária (Embrapa), constante em: IBGE, 2015, p. 287, 303.

288 COUTINHO e MELCHER, Op. cit., p. 244 


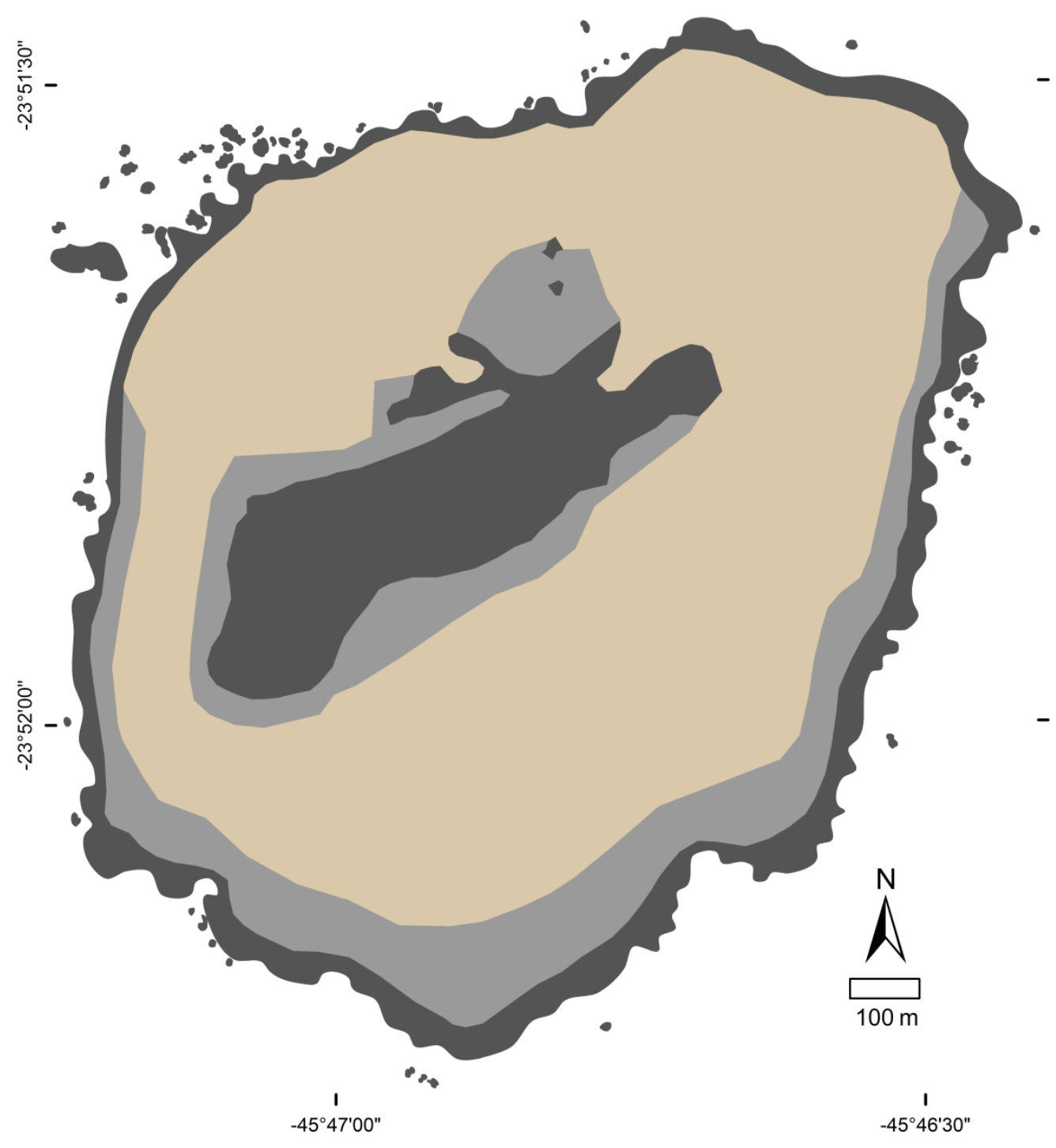

SOLOS (UM ESBOÇO)

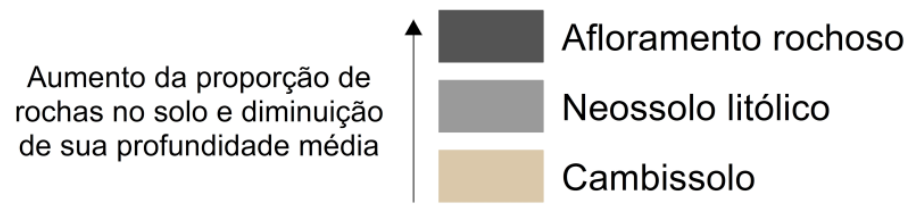

Elaboração: Menegatto, 2017

Base de referência: Ortofotos - Emplasa (2011)
Segundo Sistema Brasileiro de Classificação de Solos, da Embrapa - IBGE (2015) Fontes: Cardoso (1996); Enrich Rojas (2000);

Sartorello (2010)

Figura 65. Croqui pedológico esquemático de Monte de Trigo 


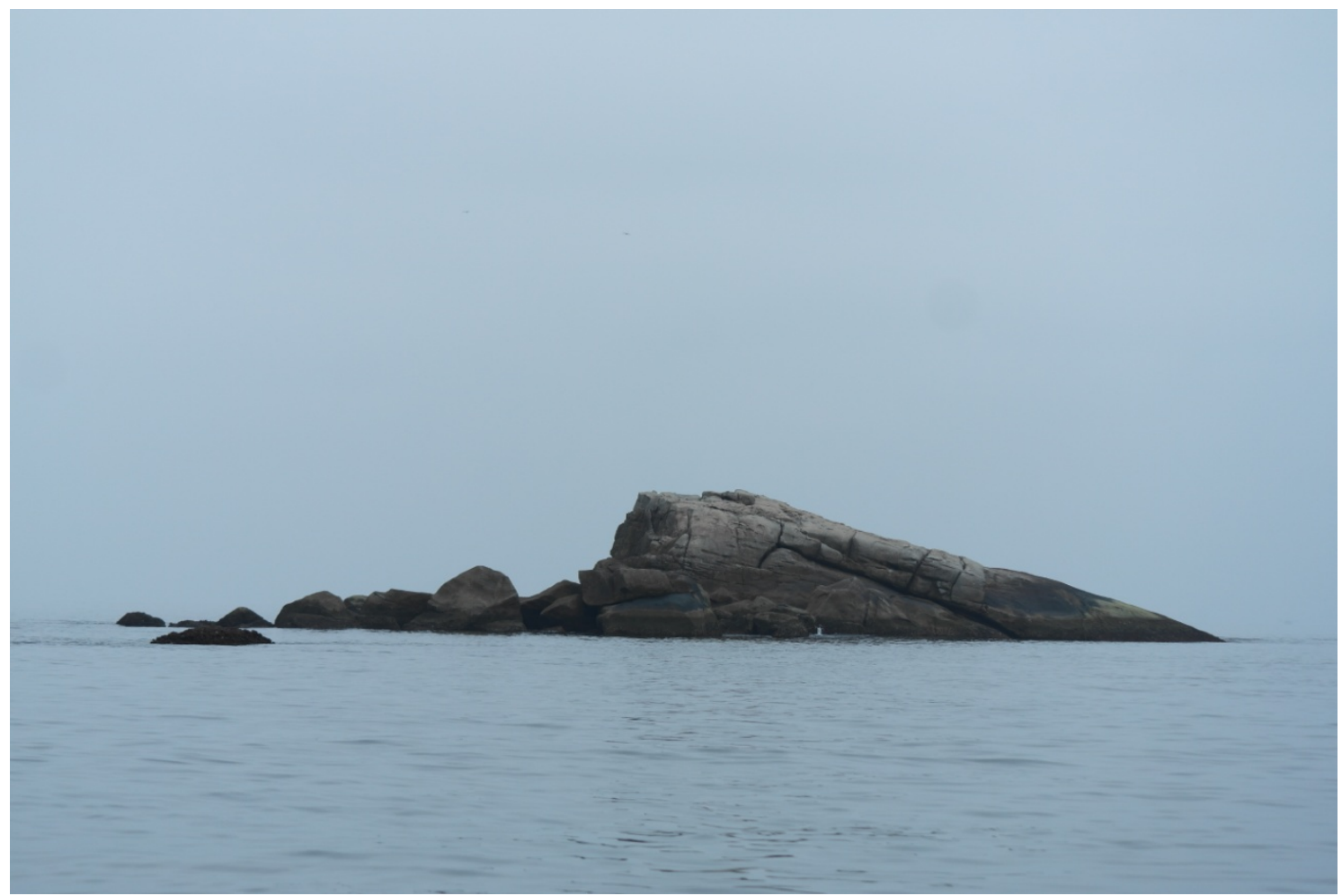

Figura 66. Fotografia da Lage, maior dos escolhos marinhos próximos a Monte de Trigo. Créditos: Douglas Scaramussa Pereira

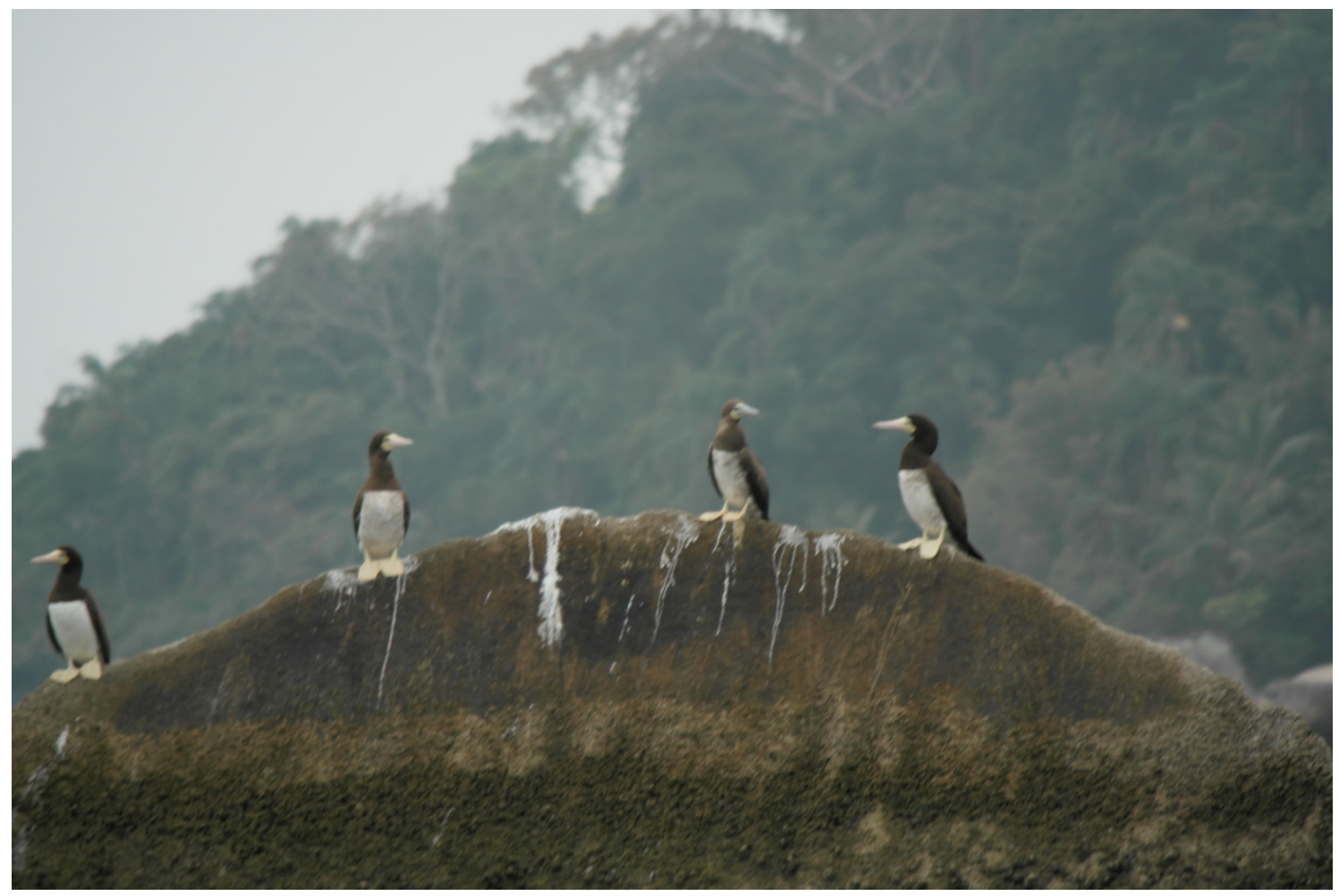

Figura 67. Avifauna dos escolhos adjacentes à ilha Monte de Trigo. Créditos: Douglas Scaramussa Pereira 


\section{Roça, pesca e pomar}

Em estudos preliminares de campo, identificaram-se formações vegetais associadas a costões rochosos e com mecanismos adaptativos à salinidade oceânica, bem como campos de gramíneas e samambaias. O domínio da Mata Atlântica, por sua vez, parece ser o aspecto dominante, com menor presença na proximidade do povoado setentrional, onde ocorre "a extração mais intensa de madeira para lenha, construção de casas e utensílios como remos e cabos de

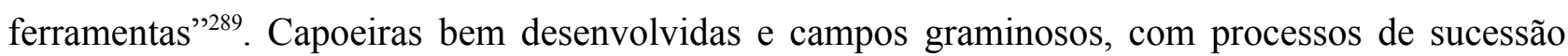
ecológica em andamento, podem ser observadas no Sítio de Lá e nos arredores da Vila dos Pescadores, dado o abandono paulatino, notadamente em finais da década de 1980, do roçado em ambas as localidades e a partida daqueles que habitavam a primeira delas ${ }^{290}$.

Tempos atrás, o binômio roça-pesca, base econômica dos caiçaras por excelência, manifestava-se de modo mais marcante na paisagem. Que se pode recuperar no histórico de produção primária da ilha, havia cultivos de batata, feijão e mandioca, hoje em número bem reduzido, quase ascendendo à vista do observador em pontos específicos do espaço insular como verdadeiros vestígios arqueológicos. A derrocada da roça deu-se, em principal, por conta de dois processos: num contexto específico, pela infestação de ratos quando da construção da escola primária; num contexto geral, dadas as transformações socioespaciais do litoral norte paulista, que inserem as comunidades tradicionais num âmbito de mercado de certo modo descompassado com suas práticas de subsistência e comercialização de excedentes agrícolas ${ }^{291}$. A cana-de-açúcar e o café ainda vigoram ${ }^{292}$.

Traço distintivo caiçara é, por seu turno, o conhecimento profundo das espécies vegetais e seu aproveitamento, seja para a produção econômica, seja para o autoconsumo (construção, alimentação, medicamentos). Entretanto - e, pela descrição, já deve ser perceptível -, não há uma distribuição geográfica uniforme de tais espécies pela ilha. O que se tem, antes, é uma regionalização de ocorrências da flora que merece menção particular. De um lado, próximo às casas dos monteiros, há uma verdadeira floresta-pomar, com coqueiros e árvores frutíferas, cujos frutos são essenciais à manutenção da vida do ilhéu e cuja estrutura conjunta de dossel e raizame protege os solos e sombreia as residências ${ }^{293}$. De outro, no maciço propriamente dito, mais ao sul, ocorre a Floresta Ombrófila Densa, com fisionomia e densidade elevadas e uma diversidade considerável de formas biológicas e estratos vegetacionais. Neste ínterim, por vezes, tão sombrios e úmidos serão os 289 CARDOSO, 1996, p. 38

290 loc. cit.

291 Ibidem, p. 53

292 BARROS, Op. cit., p. 140-141

293 CARDOSO, 1996, p. 38 
estratos inferiores quanto for o potencial de obstrução da radiação solar e retenção hídrica das lianas, epífitas, palmeiras e fetos arborescentes altimetricamente superiores. Já em linhas de cumeada ou em vertente, ao contrário do que ocorre nos fundos de vale, as árvores altas e seu intenso dossel impedem a existência de sub-bosque ${ }^{294}$. A termo, na condição de espaço intergrades, a floresta secundária e os campos graminosos impõem-se ao espaço monteiro como alternativas para o extrativismo vegetal. Aliás, em levantamento de campo, pudemos verificar o aproveitamento da madeira e da folha da bananeira para, em respectivo, a construção de casas e o trabalho artesanal. Afora tais fatos, podem-se citar os seguintes frutos e plantas aproveitados pelos ilhéus: maracujá, goiaba, pitanga, mamão, jabuticaba, banana, manga, jaca, coentro, capim cidreira, ervadoce, boldo, hortelã, quebra-pedra e grumixama ${ }^{295}$, para bem empregar a nomenclatura popular, afora algumas cactáceas e suculentas situadas na picada rumo ao topo do Montão.

Sobre a atividade pesqueira monteira, esta sim, a base estruturante dessa comunidade de pouco mais de meia centúria de almas, tanto do ponto de vista material quanto do simbólico, alargam-se as referências de pesquisa. Nelas, é possível verificar quatro modalidades principais de pesca quanto à armadilha utilizada: de rede (ora de fundo, ora de cerco, ora de boiada), de linha (parada ou de currico), de zangarelho e de espinhel. Tenha-se em vista, anteriormente, a natureza de cada uma delas, e, posteriormente, a fauna marinha capturada, e o retrato será: no primeiro caso, via redes de espera ou por cerco ao cardume por duas ou mais canoas, os alvos são, com frequência, as tainhas; no segundo, o fundeamento próximo aos parcéis dá-se individualmente, focando os famigerados peixes de pedra (garoupas, caranhas, chernes, meros), além de enchovas e bicudas; no terceiro, indivíduos ou duplas empregam canoas a remo para a captura de lulas; e, finda a listagem, um cabo de vários anzóis alveja cações, garoupas e cernes ${ }^{296}$.

Até meados da década de 1970, a pesca monteira era mais sólida - em termos de ganhos monetários e de espaço e peixes disponíveis - do que o é na atualidade. A chegada de embarcações de arrastos e de parelhas (em enorme medida, advindas do Rio de Janeiro e de Santa Catarina), nos anos subsequentes, acabou por constranger esses caiçaras, quer porque precisavam competir com empresas pesqueiras de capacidade técnica superior, quer porque não possuíam força política tampouco unidade estratégica para firmarem raízes territoriais nos mares circundantes à ilha. Não obstante, nas águas próximas ao Montão, os conflitos também se dão entre monteiros e pescadores artesanais do continente, sendo potencialmente mais intensos no verão (de dezembro a março), quando as atividades se tornam mais concentradas, haja vista tanto o número de recursos disponíveis nessa estação do ano quanto o mar mais abrigado (menos grosso, no linguajar dos 
ilhéus) das frentes frias (de frequência mais acentuada no inverno). De remate, tenha-se em mente que a pesca não é apenas considerada uma atividade arriscada como também é competitiva, uma vez que "o mar é considerado patrimônio comum" 297 .

Cada vez mais, a pressão sobre os monteiros intensifica-se, fomentando, inclusive, episódios emigratórios. Isso porque suas três bases econômicas estão em situação de confrangimento - as roças minguaram, o extrativismo vegetal encontrou (mais recentemente) os impeditivos da legislação ambiental e os conflitos por peixes, crustáceos e moluscos tendem a se alastrar.

\footnotetext{
No entanto, como a ilha sempre foi um local estratégico para a pesca e para a navegação, contando com inúmeras lajes e parcéis e servindo aos navegantes de abrigo e de descanso, os moradores sempre se viam em uma situação dúbia e conflitante. Ao mesmo tempo em que praguejavam contra a presença dos grandes barcos e o tipo de pesca criminosa que era realizada no entorno da ilha, aceitavam, sem o menor questionamento, as irrisórias doações dos embarcados, como, por exemplo, alguns quilos de gelo, camarão ou, até, peixes (LIMA, 2014, p. 54).
}

Se adequada mostrar-se a fiscalização, com o estabelecimento de uma Área de Preservação Ambiental (APA) na região marítima onde se situa a ilha Monte de Trigo, espera-se minimizar conflitos. Pois, sendo uma Unidade de Conservação de Uso Sustentável, haveria impeditivos à pesca empresarial de grande envergadura, ao passo que continuariam possíveis, do ponto de vista da legislação, as atividades haliêuticas artesanais das populações tradicionais (realizadas nos padrões culturais historicamente estabelecidos), bem como as de modalidade amadora e esportiva, desde que praticadas de modo sustentável. Ademais, na persistência do conflito, o zoneamento pesqueiro e a limitação do número de embarcações de frete seriam alternativas talvez praticáveis ${ }^{298}$.

Além do autoconsumo, a pesca monteira possui traços tipicamente comerciais, a despeito de seus resultados monetários frequentemente irrisórios. A venda de peixes na Barra do Una, na praia do Juquehy e, no máximo, em outras localidades próximas no município de São Sebastião, inserem Montão de Trigo no padrão tipicamente insular paulista, “com descarga em localidade próxima ao centro de comercialização" ${ }^{299}$. Por sua vez, as embarcações externas que pescam no entorno da ilha descarregam também na costa continental, contudo um pouco mais ao sul ${ }^{300}$.

297 TERAMOTO, 2014, p. 75, 81-82

298 Ibidem, p. 71, 87

299 SILVA, 2014, p. 32

300 Ibidem, p. 22 
$45^{\circ} 45^{\prime} \mathrm{O}$

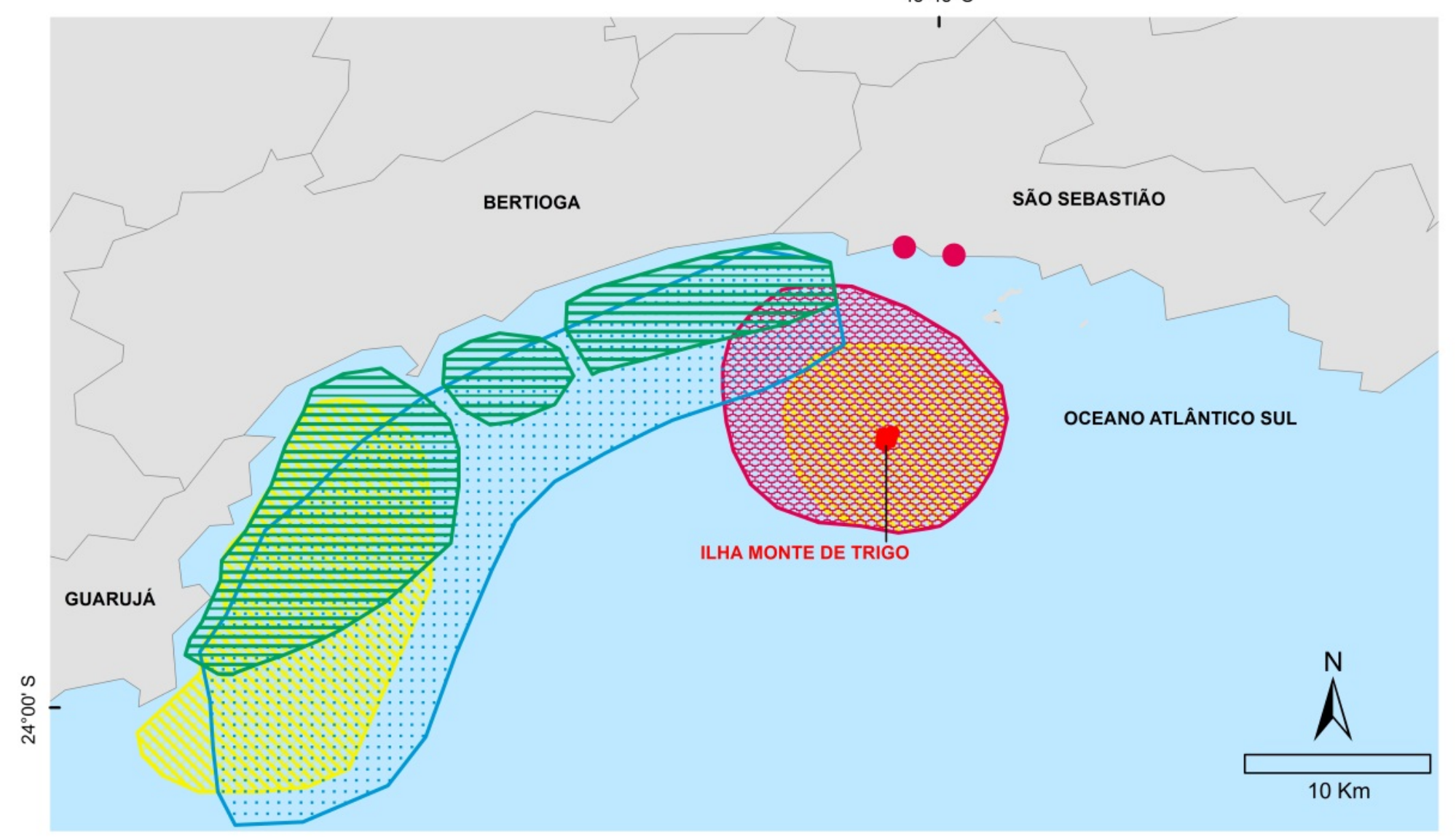

\section{ATIVIDADE PESQUEIRA}

Artesanal (de comunidades caiçaras) Comercial (não caiçara)

F 5 Pescadores amadores

E de Bertioga (rede-de-malhe de espera) $\quad \ldots:$.: Frota de pesca de arrasto-duplo

Pontos preferenciais dos monteiros para a comercialização de seus peixes
Elaboração: Menegatto, 2017
Base de referência: Ortofotos - Emplasa (2011)
Limites municipais - IGC (2015)
Adaptado de Teramoto (2014)

Figura 68. Mapa da atividade pesqueira nas regiões de Bertioga e São Sebastião 


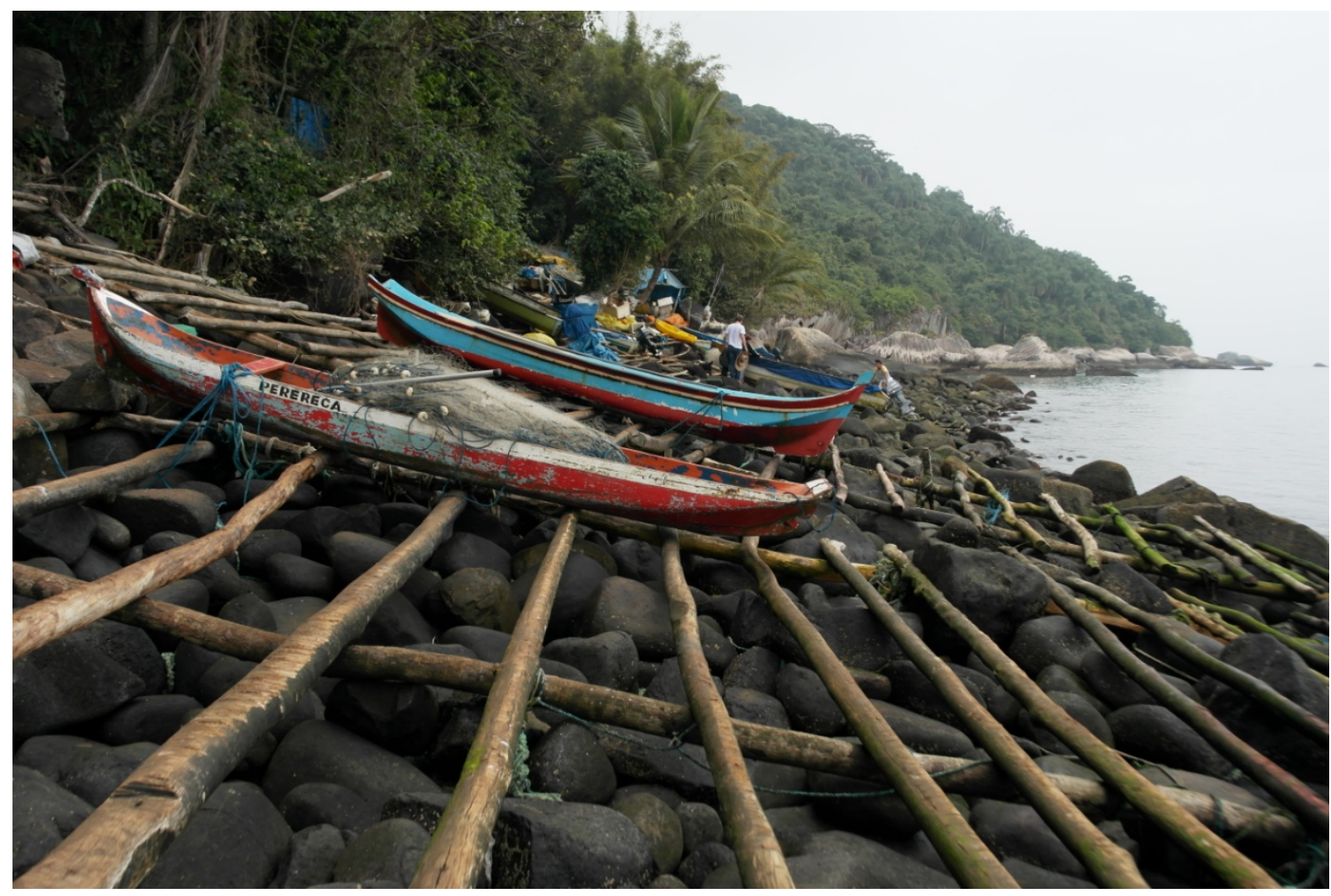

Figura 69. Fotografia do atracadouro com suas estivas características. Créditos: Douglas Scaramussa Pereira

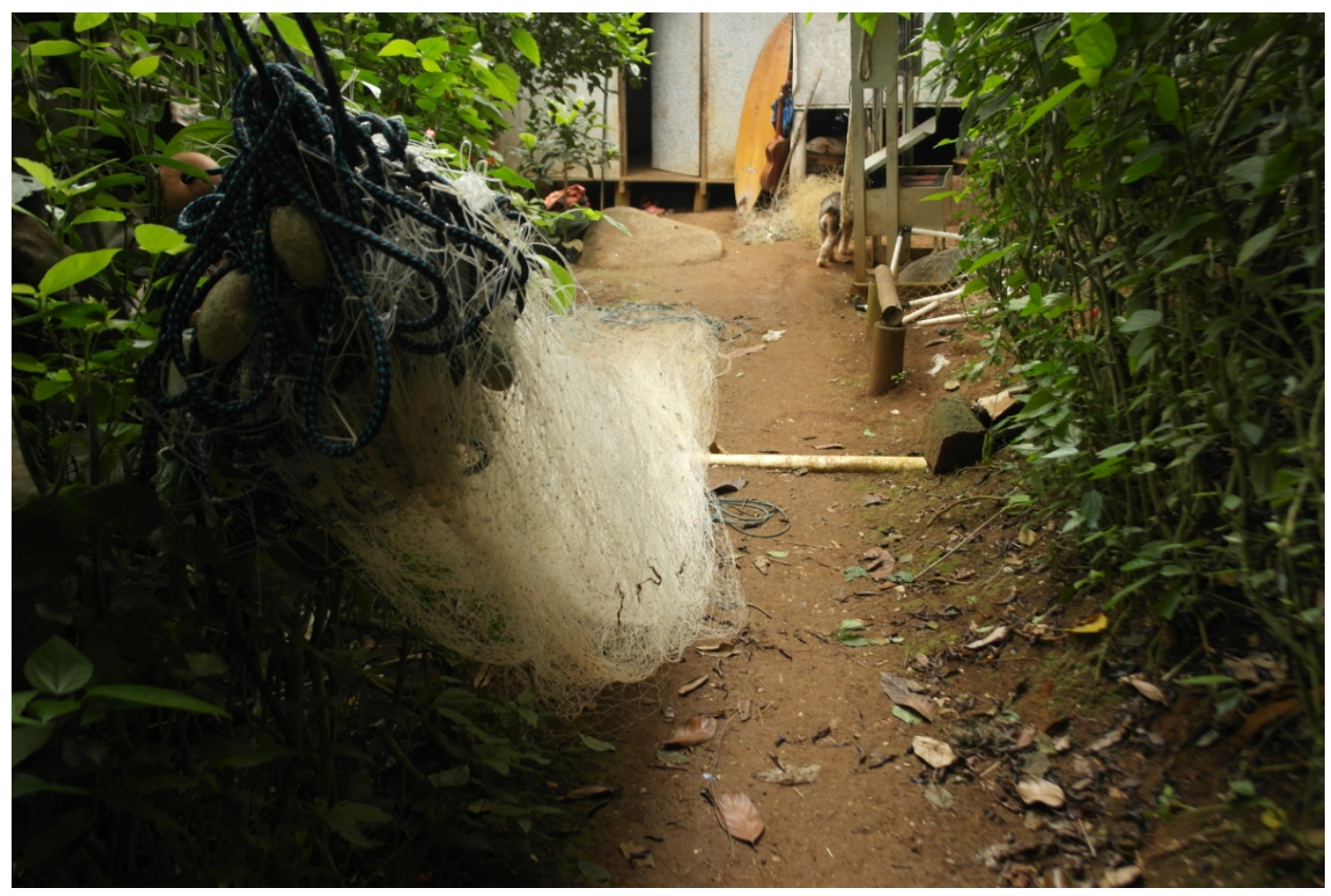

Figura 70. Fotografia de rede de pesca utilizada pelos monteiros. Créditos: Douglas Scaramussa Pereira 
Em movimento contrário à pressão econômica que vêm sofrendo os monteiros ou, talvez, em virtude dela, nota-se já certa mudança no padrão tecnológico das embarcações de pesca dos ilhéus. Se, na década de 1990, havia sido identificada a existência de quatro embarcações motorizadas (duas canoas, um bote e uma chata de alumínio), sendo apenas duas dessas de propriedade monteira, transcorridos vinte anos, encontram-se, no mesmo local, sete embarcações de pescaria organizada (todas dos habitantes da ilha, seis delas constituídas de chatas de alumínio); donde se derivam tanto vantagens (maior rapidez de deslocamento, facilidade de guarda nas estivas construídas nos costões rochosos da ilha) como desvantagens (baixa capacidade de carga e alto custo dos combustíveis) ${ }^{301}$.

Ora, se bem elencamos os espaços florestados com níveis de antropização mais modestos e se já apresentamos a distribuição e o papel desempenhado pela agricultura, pela pesca e pelo extrativismo vegetal no âmbito do ambiente insular, para bem operarmos um mapa de uso e cobertura das terras de Monte de Trigo, falta-nos discorrer sobre três tópicos capitais: 1. As diferenciações existentes internamente à floresta ombrófila densa; 2. A fauna continental e aquática; 3. As demais atividades econômicas praticadas em terras emersas. Vejamos, parágrafo a parágrafo, cada um deles.

\section{Manifestações da floresta ombrófila}

No que concerne às diferenciações intestinas da pluvissilva sempre-verde, típica do maciço monteiro, observam-se, nas concavidades oriundas de dissecação da vertente oriental, a floresta ombrófila densa aluvial (com dossel emergente uniforme, fanerófitos de rápido crescimento e ocorrência de epífitas e lianas); nas isoípsas imediatamente adjacentes ao costão meridional, a floresta ombrófila densa de terras baixas (de pouca representatividade e com menor densidade de submata); e, a termo, no restante do maciço, tirante o topo de relicto campestre e lajeado, a floresta ombrófila densa submontana (predominante e bem distribuída, com fanerófitos de altura aproximadamente uniforme) $)^{302}$.

\section{Fatos da fauna}

Já no caso de empreendermos um inventário faunístico do espaço monteiro, temos, dentre os representantes terrestres, dois grupos principais de mamíferos, o das espécies nativas (em que se

301 CARDOSO, 2012, p. 54-55

302 IBGE, 2012, p. 67-71 
elencam o ratinho do mato, o morcego, o gambá e o quati) e os introduzidos (cotias, cabras, ratos, porcos, gatos e cães $)^{303}$. Somem-se a essa classe de animais as aves (galinhas, gansos, patos e pássaros, como sabiás-pretos), os lagartos e os aracnídeos, bem como um sem par número de insetos. Inclusive, em estudos de distribuição geográfica de mosquitos culicídeos (transmissores de enfermidades como malária, filariose, dengue, febre amarela e encefalite), foram encontrados, na ilha, exemplares da espécie Stegomyia albopicta, ainda não incriminados, até o presente momento, como vetores de qualquer uma dessas doenças tropicais ${ }^{304}$. Diferentemente de outras ilhas do litoral paulista, como Búzios, Vitória e Queimada Grande, não há quaisquer serpentes ${ }^{305}$, consequência, decerto, do insularismo, condição de isolamento que bloqueou o fluxo migratório desses répteis oriundos de outras terras, insulares ou continentais.

Geograficamente, se se intenta compreender a distribuição dos organismos písceos, é factível a compartimentação das águas circundantes ao costão rochoso subvertical tendo por referências três pontos distintos: o Portinho (ou, como já a ele se aludiu, Porto do Imbiru), cujo mar de águas abrigadas dos ventos de sul possui profundidade de 6 a 9 metros, substrato arenoso com matacões esporádicos e representação de linguados, sargentinhos, donzelas e tartarugas marinhas; o costão do sudoeste, cujo mar de águas abrigadas dos ventos de leste e sudeste conta com profundidade de 7 a 18 metros, grandes rochas de notável adjacência (formadoras de tocas, grutas, salões e passagens de toda sorte) e presença de salemas, cirurgiões, budiões, pargos, badejos, lagostas e pequenos crustáceos; e, afinal, a Ponta Negra, cujas águas agitadas (abertas aos ventos de leste) valem-se de nítida ação das correntes marítimas e encobrem um fundo de lajes onde figuram salemas, sargentinhos, xareletes, budiões e jaguareçás ${ }^{306}$. De mais a mais, na sequência desses peixes e animais correlatos de interesse para a pesca e para o mergulho, na zona entremarés e no infralitoral raso do costão rochoso, registram-se ascídias, "organismos incrustantes que constituem uma parte importante da fauna bêntica de substratos consolidados"307.

\section{Atividades econômicas}

Enfim, dentre os aspectos tangentes à economia monteira, é de se frisar outras atividades afora os incipientes cultivos e o extrativismo (vegetal terrestre e animal aquático). De saída, elencam-se as atividades domésticas, o ensino formal (pagamento de salário a uma professora e à

303 VARJABEDIAN, 1996 apud CARDOSO, 1996, p. 38-39

304 PEREIRA et al., Op. cit., p. 69

305 CARDOSO, 1996, p. 39

306 Para mais informações acerca desses suprarreferidos pontos do costão monteiro, acesse o sítio eletrônico do Brasil

Mergulho: <http://www.brasilmergulho.com/port/points/sp/montao_trigo.shtml $>$.

307 ROCHA et al., 2011, p. 750-754 
merendeira da escola), a limpeza das trilhas e da escola (remuneradas pelo Iate Clube da Barra do Una e pela Prefeitura Municipal de São Sebastião, respectivamente), a manutenção das embarcações e o artesanato ${ }^{308}$. Quanto a este, citam-se os remos, as miniaturas de embarcações e gaiolas (produção majoritariamente masculina); as toalhas, os tapetes e as bolsas e chapéus de palha (confecção predominantemente feminina) ${ }^{309}$; sendo que sua comercialização está voltada para os turistas no continente ou nas próprias ilhas (onde aportam alguns mergulhadores e pesquisadores). 
Uso e Cobertura das Terras

\section{VEGETAÇÃO NATURAL}

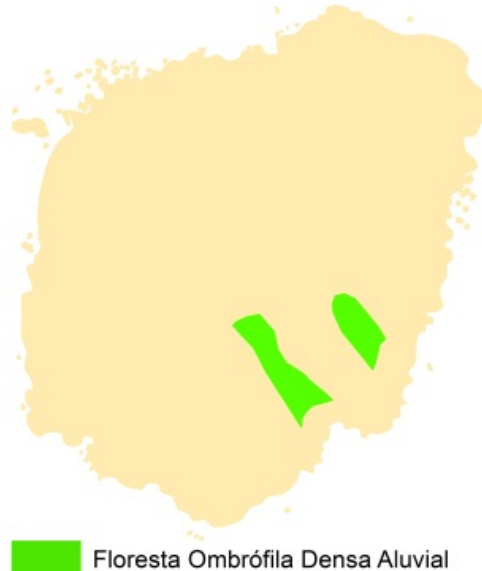

Floresta Ombrófila Densa Aluvial

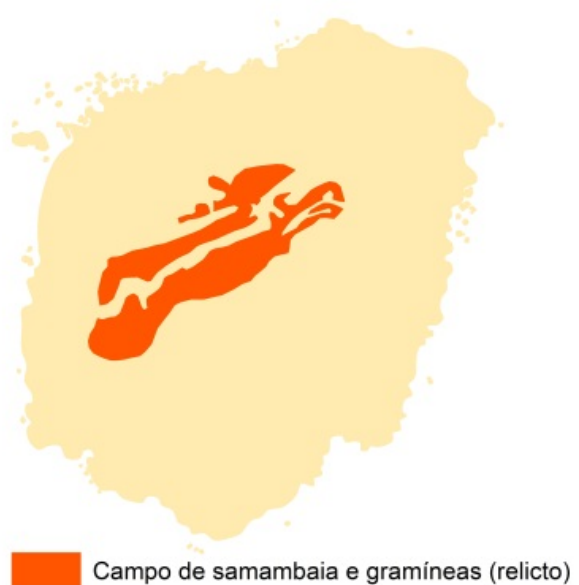

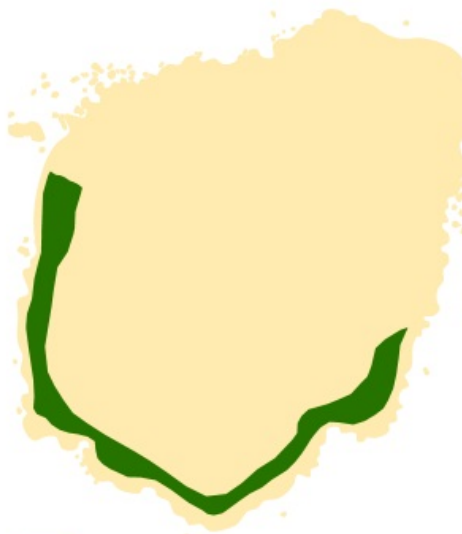

Floresta Ombrófila Densa de Terras Baixas AFLORAMENTO ROCHOSO

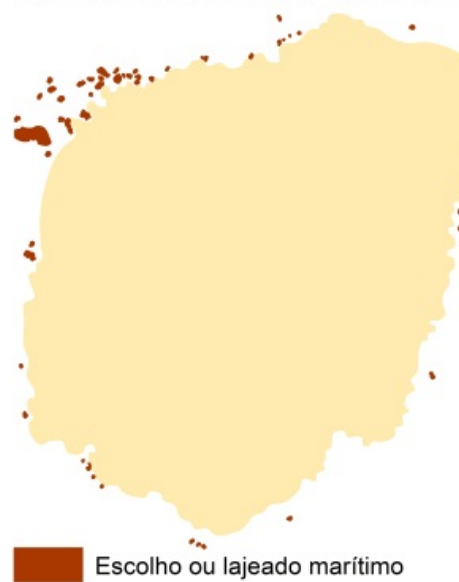

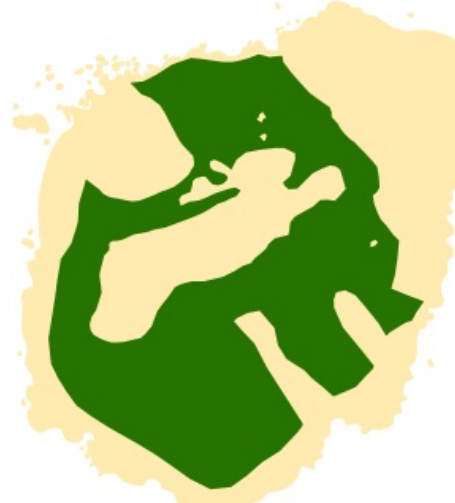

Floresta Ombrófila Densa Submontana $45^{\circ} 47^{\prime} \mathrm{O}$

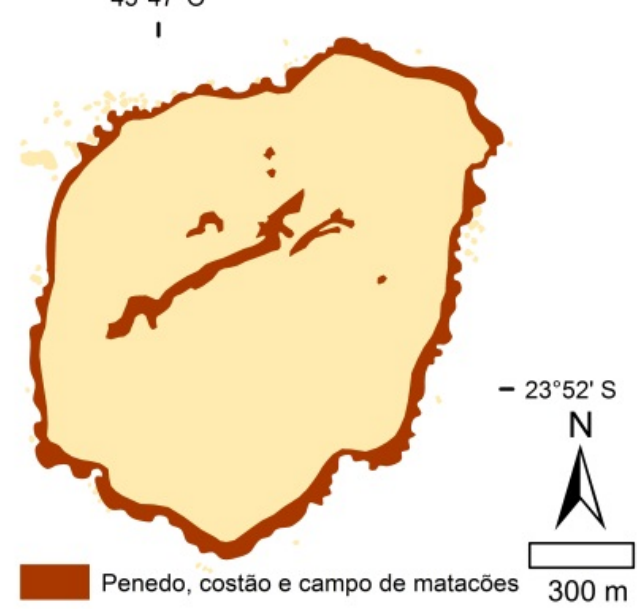

Elaboração: Menegatto, 2017. Base de referência: Ortofotos - Emplasa (2011). Classificaçao dos Manuais Técnicos de Uso da Terra e da Vegetação Brasileira - IBGE (2012, 2013)

Figura 71. Mapa de uso e cobertura das terras (vegetação natural e afloramentos rochosos) em Monte de Trigo 
Uso e Cobertura das Terras

\section{TRATOS ANTRÓPICOS}

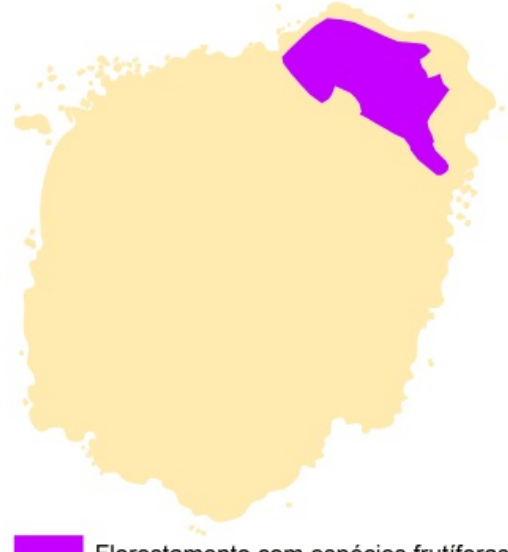

Florestamento com espécies frutiferas

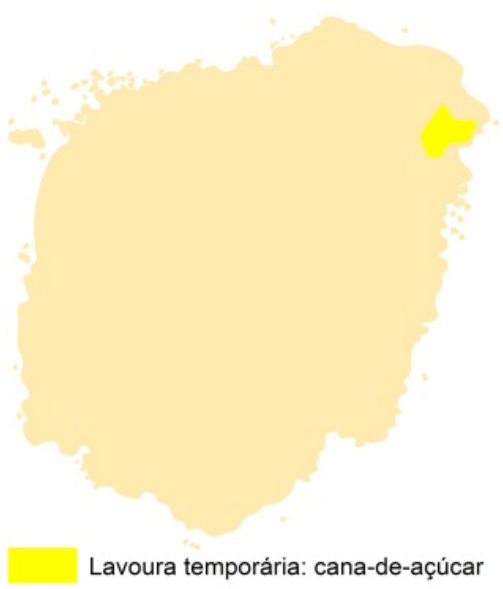

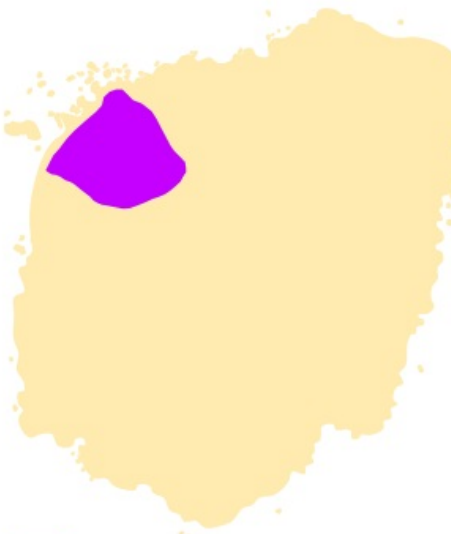

Vegetação secundária (capoeira) e florestamento frutifero

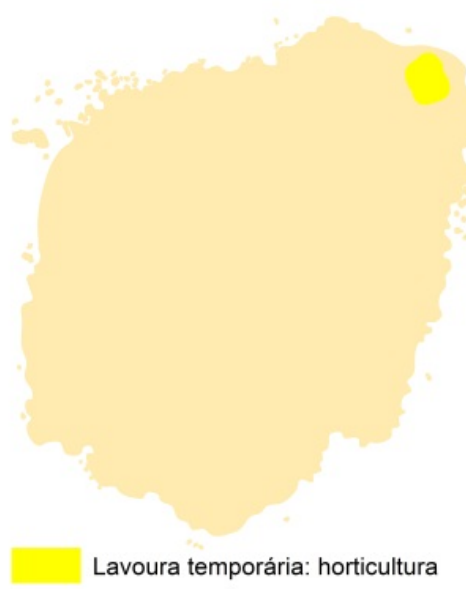

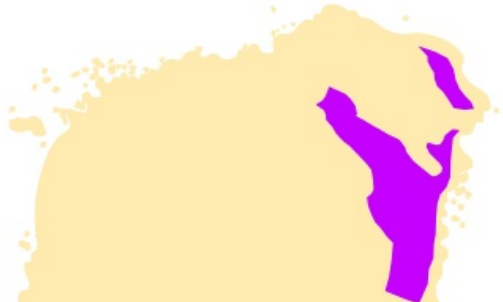

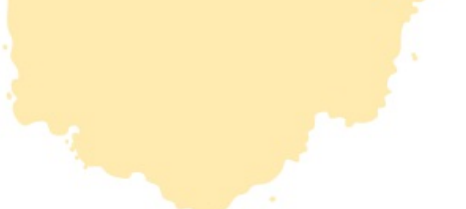

Vegetação secundária (capoeira) e áreas de coleta vegetal

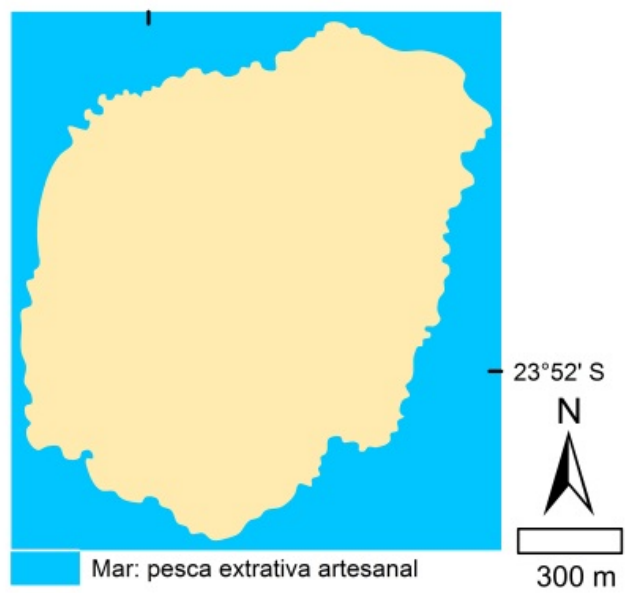

Elaboração: Menegatto, 2017. Base de referência: Ortofotos - Emplasa (2011). Classificaçao dos Manuais Técnicos de Uso da Terra e da Vegetação Brasileira - IBGE (2012, 2013)

Figura 72. Mapa de uso e cobertura das terras (tratos antrópicos) em Monte de Trigo 


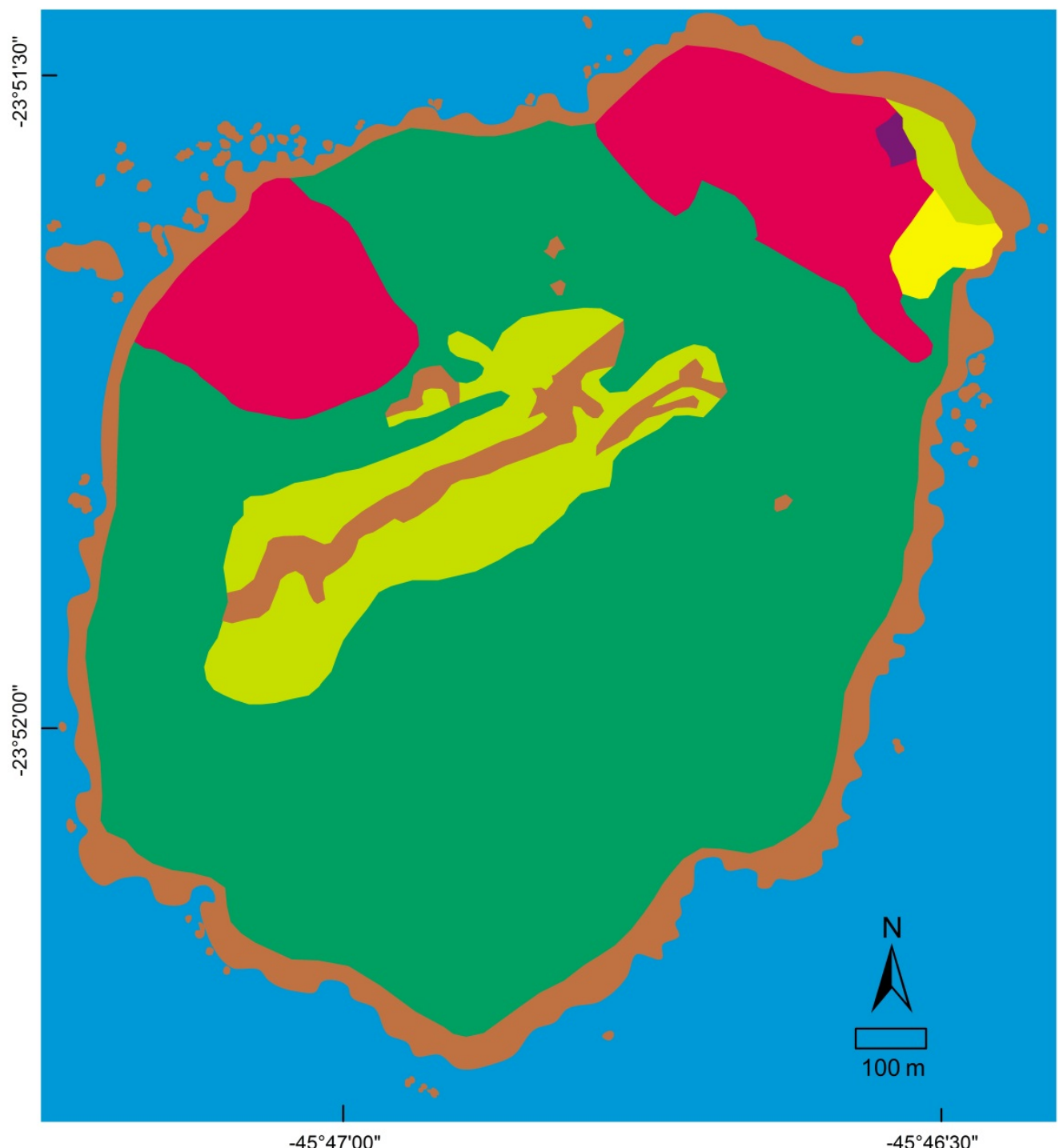

Uso e Cobertura das Terras: Vocabulário Caiçara

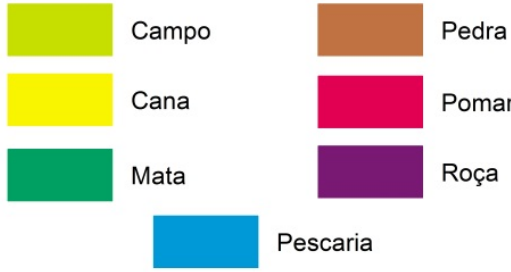

Elaboração: Menegatto, 2017

Classificação segundo vocabulário do Dicionário Caiçara - Németh (2010) Base de referência: Ortofotos - Emplasa (2011)

Figura 73. Mapa de uso e cobertura das terras em Monte de Trigo segundo o vocabulário caiçara 


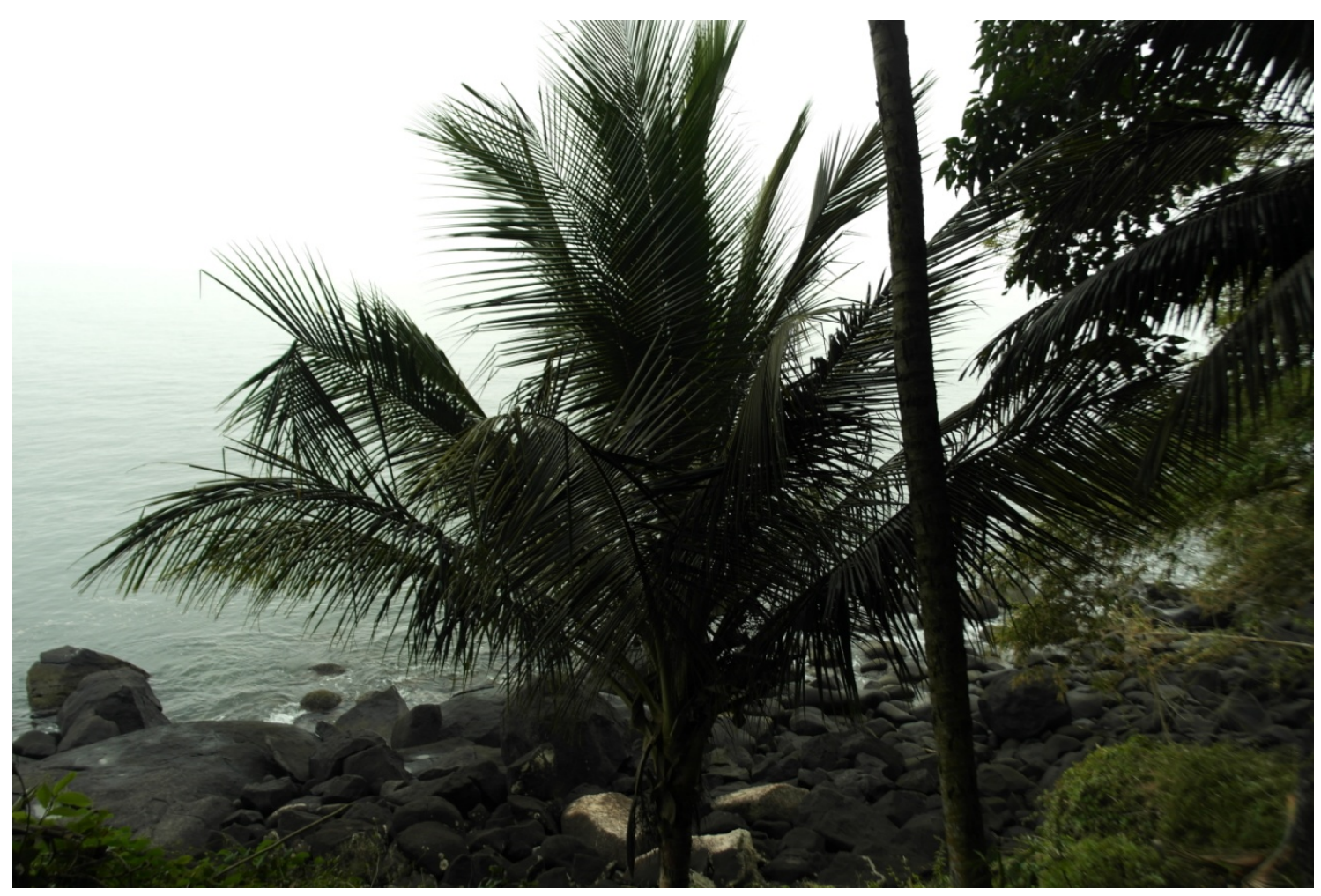

Figura 74. Fotografia de coqueiro na Vila dos Pescadores. Créditos: Douglas Scaramussa Pereira

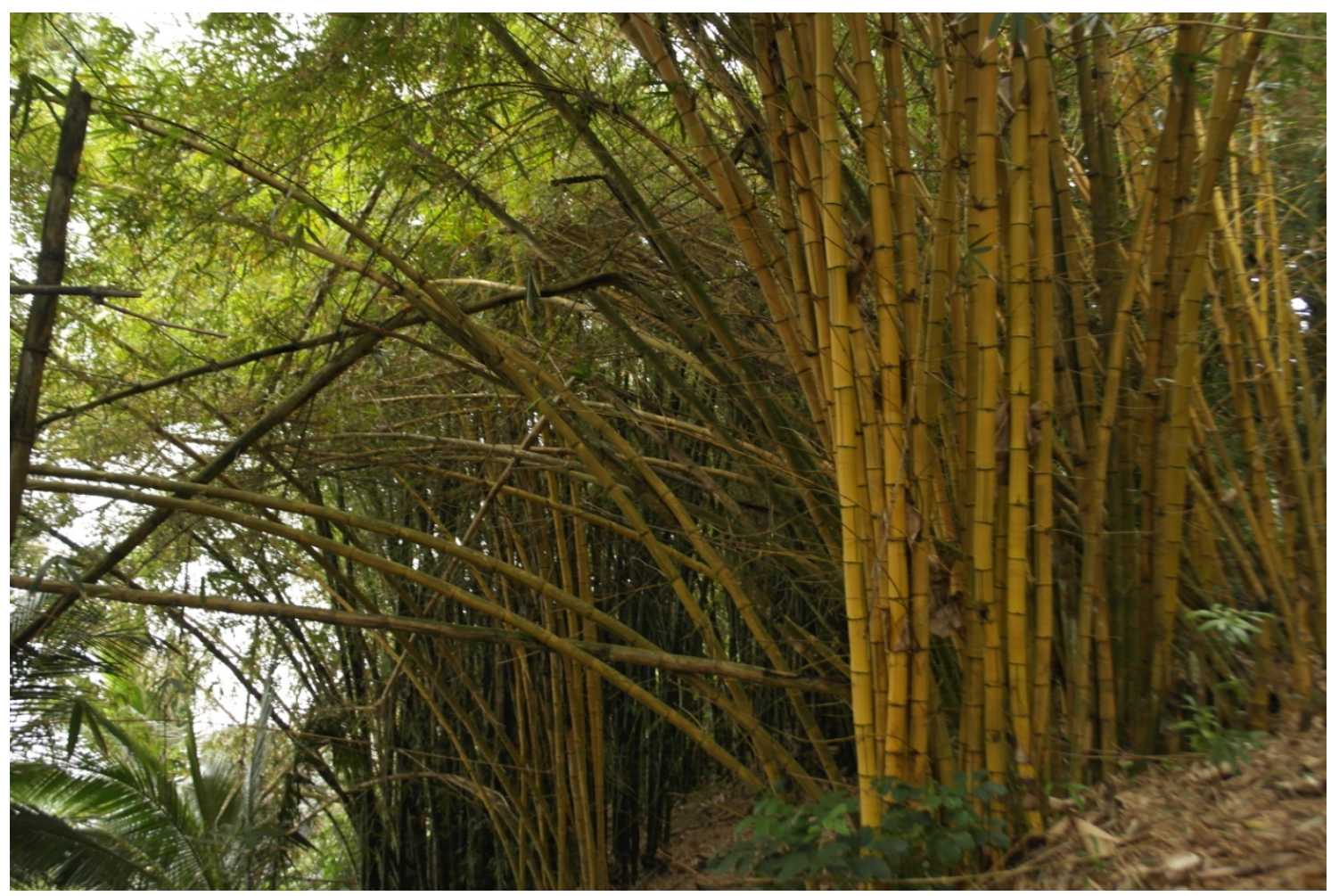

Figura 75. Fotografia de bambuzal na Vila dos Pescadores. Créditos: Douglas Scaramussa Pereira 


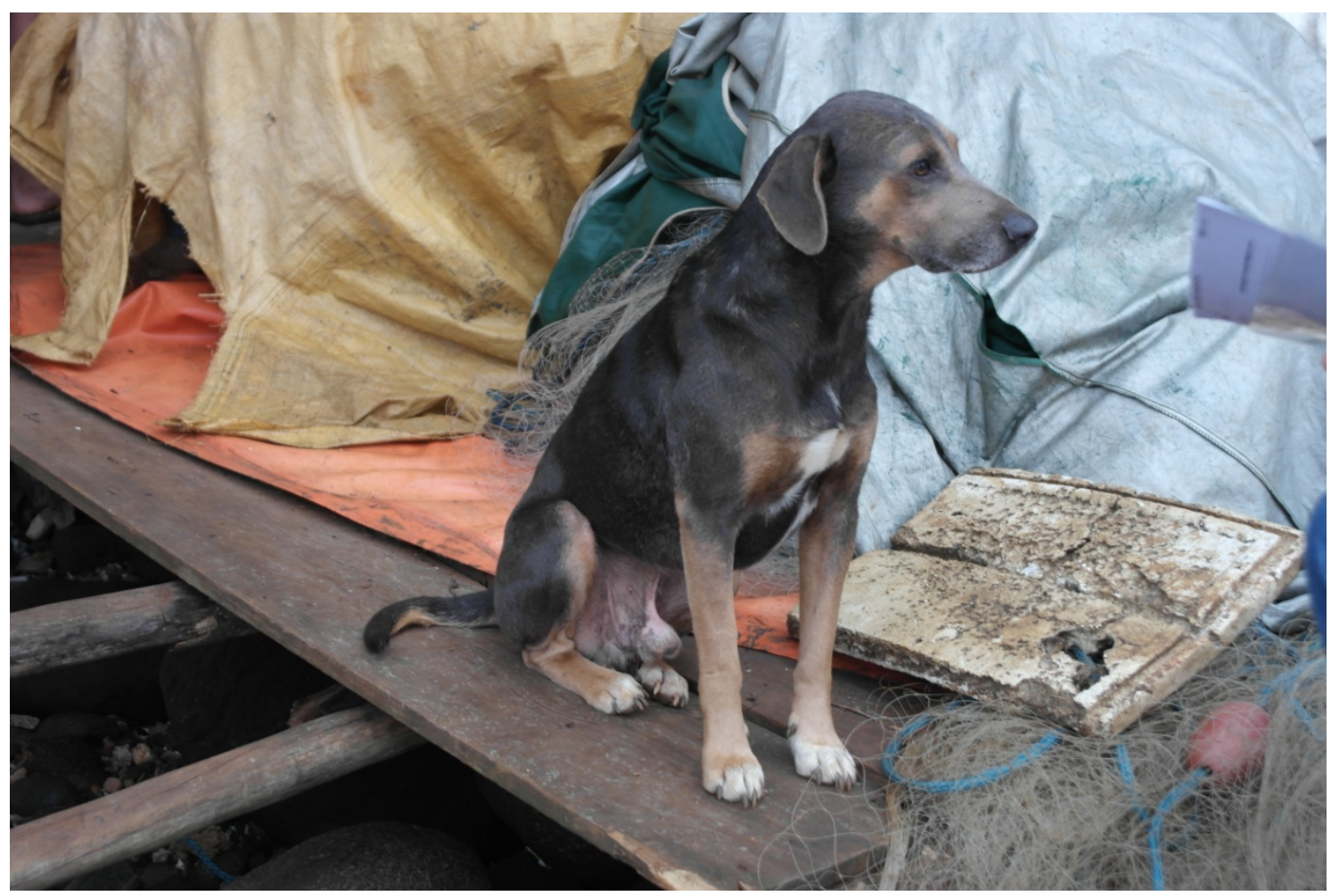

Figura 76. Fotografia de cão, espécie introduzida em Monte de Trigo. Créditos: Douglas Scaramussa Pereira

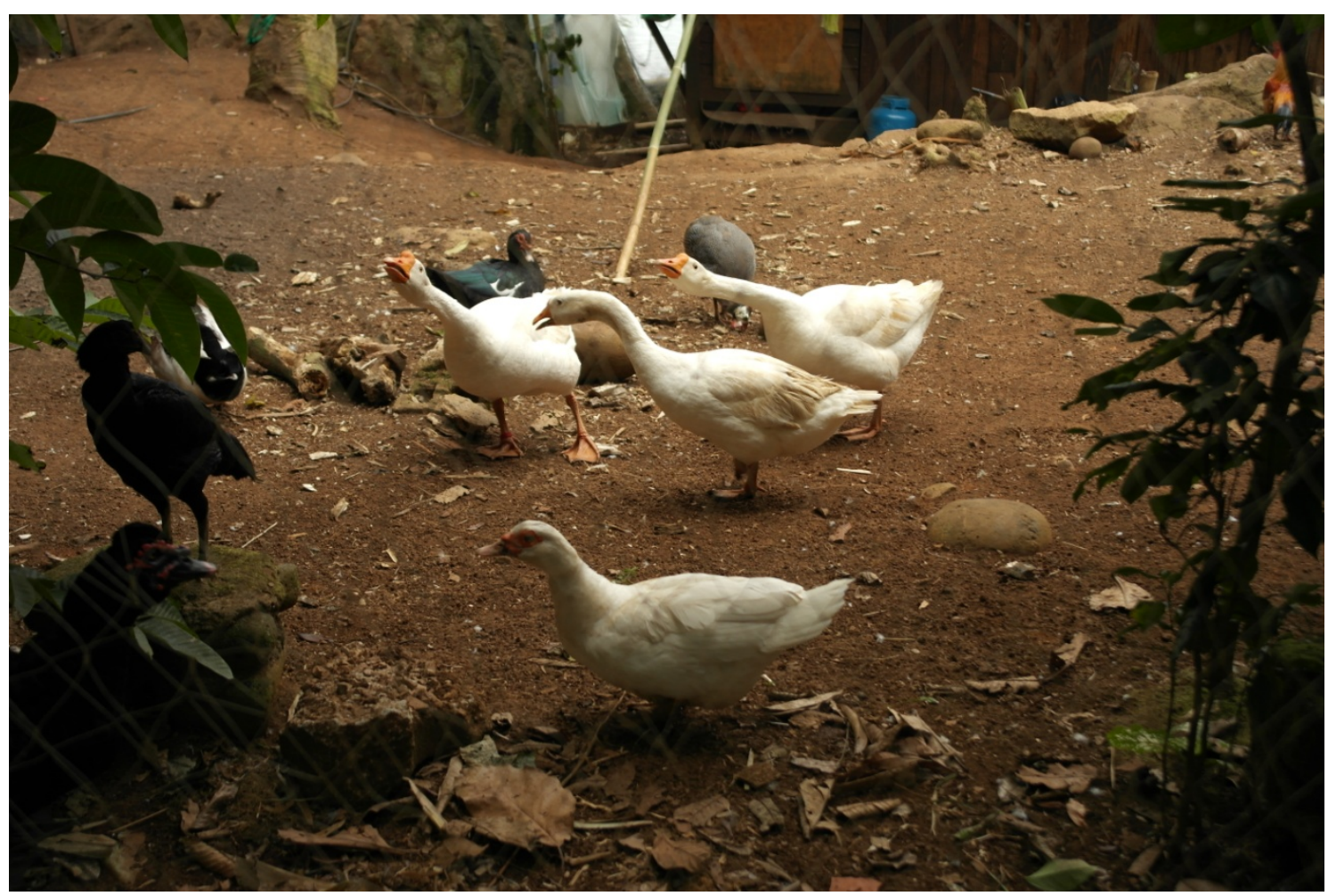

Figura 77. Fotografia de galinhas, patos e gansos, também espécies introduzidas em Monte de Trigo. Créditos: Douglas Scaramussa Pereira 


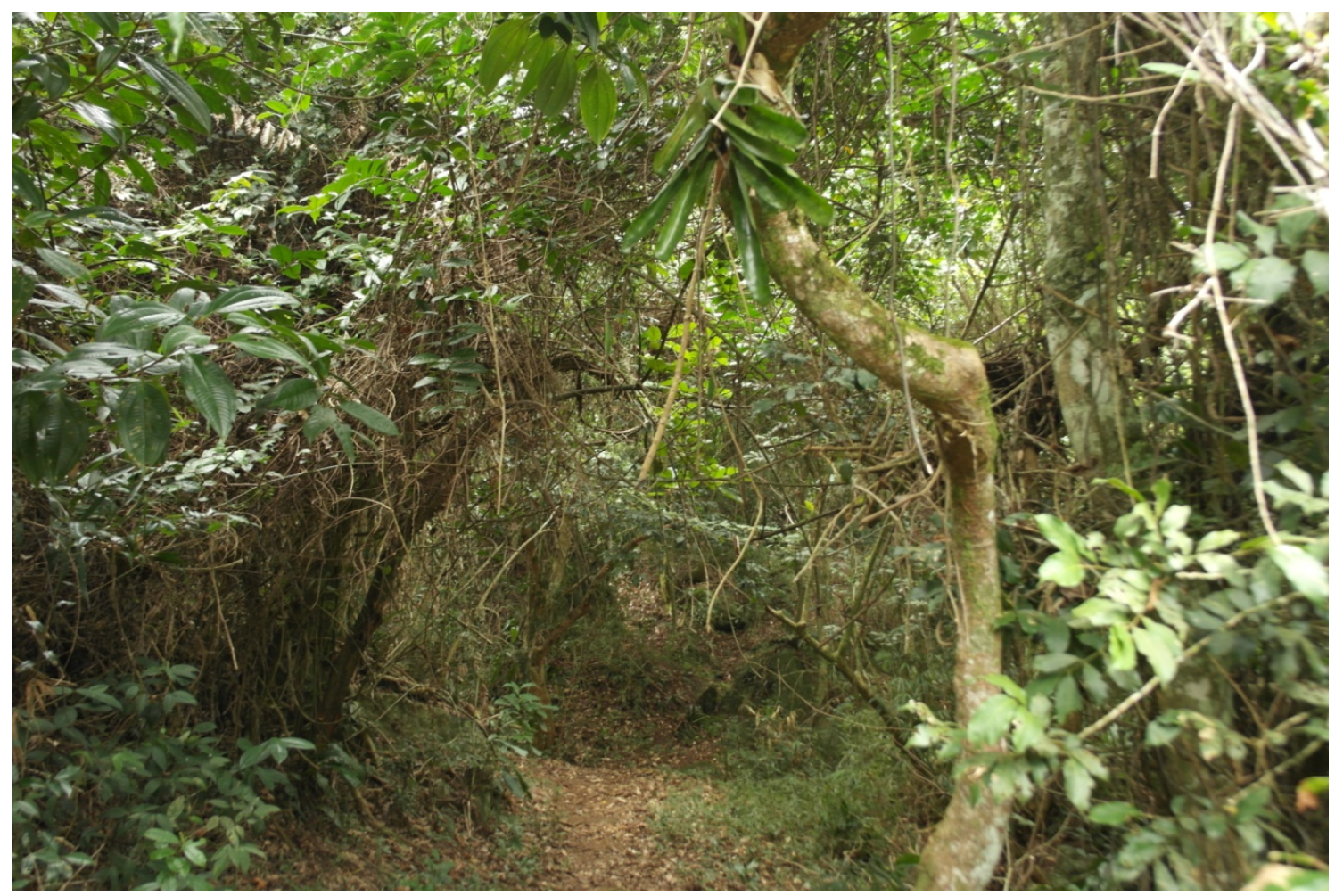

Figura 78. Fotografia de fanerófitos com lianas, vistos da trilha. Créditos: Douglas Scaramussa Pereira

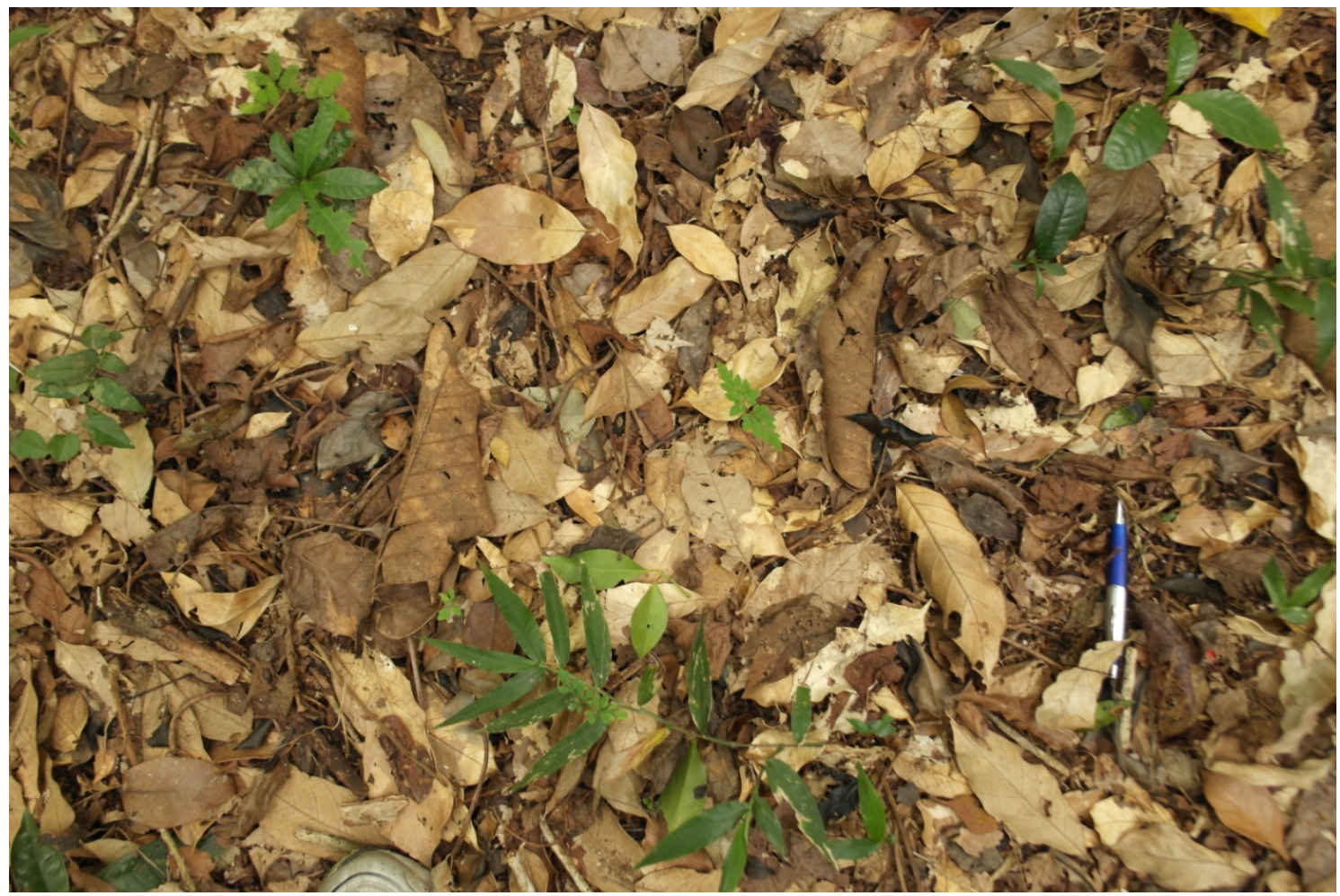

Figura 79. Fotografia da serrapilheira florestal. Créditos: Douglas Scaramussa Pereira 


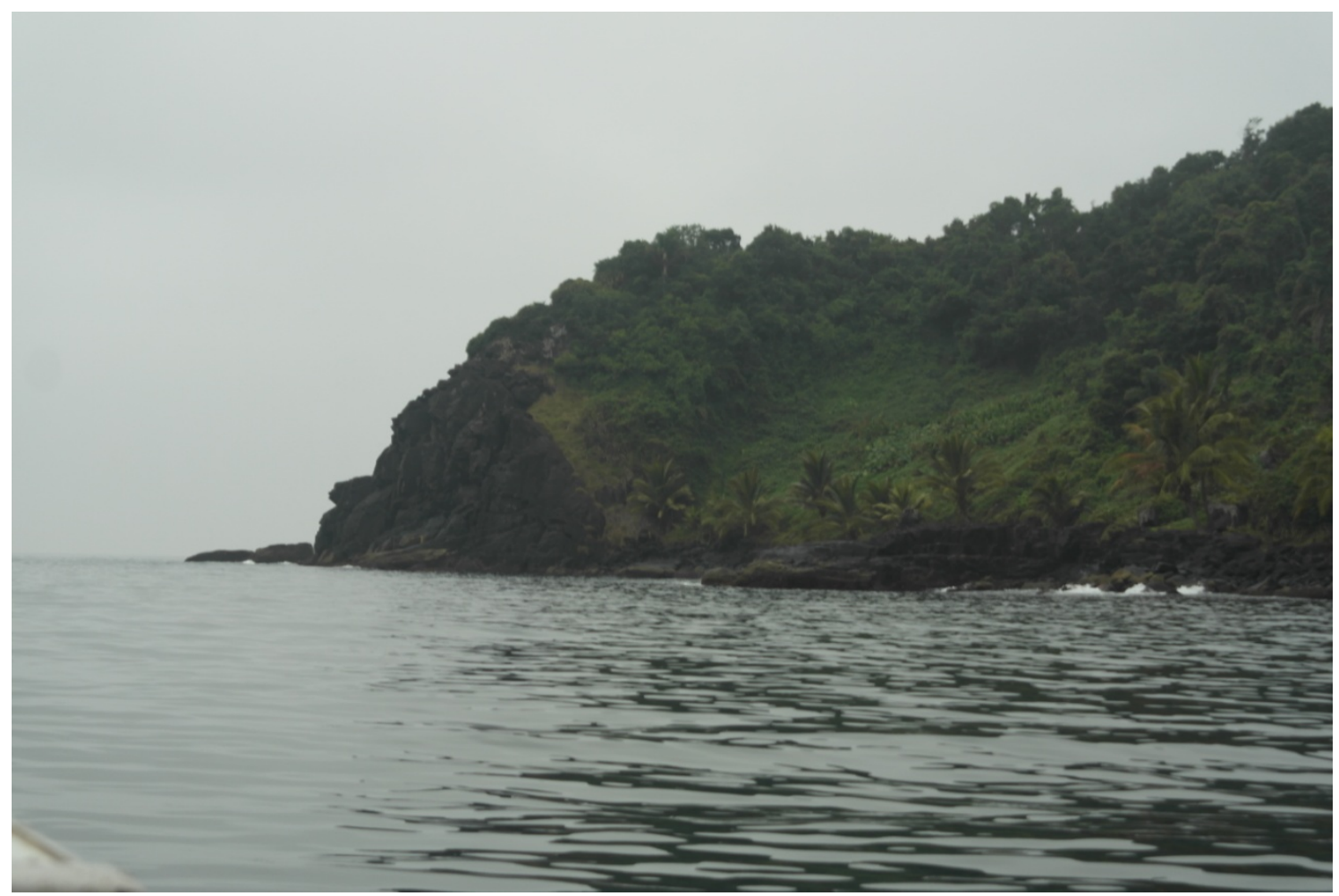

Figura 80. Fotografia do costão com presença de espécies vegetais nativas (de porte herbáceo e arbóreo) e introduzidas (cana-de-açúcar, coqueiros). Créditos: Douglas Scaramussa Pereira

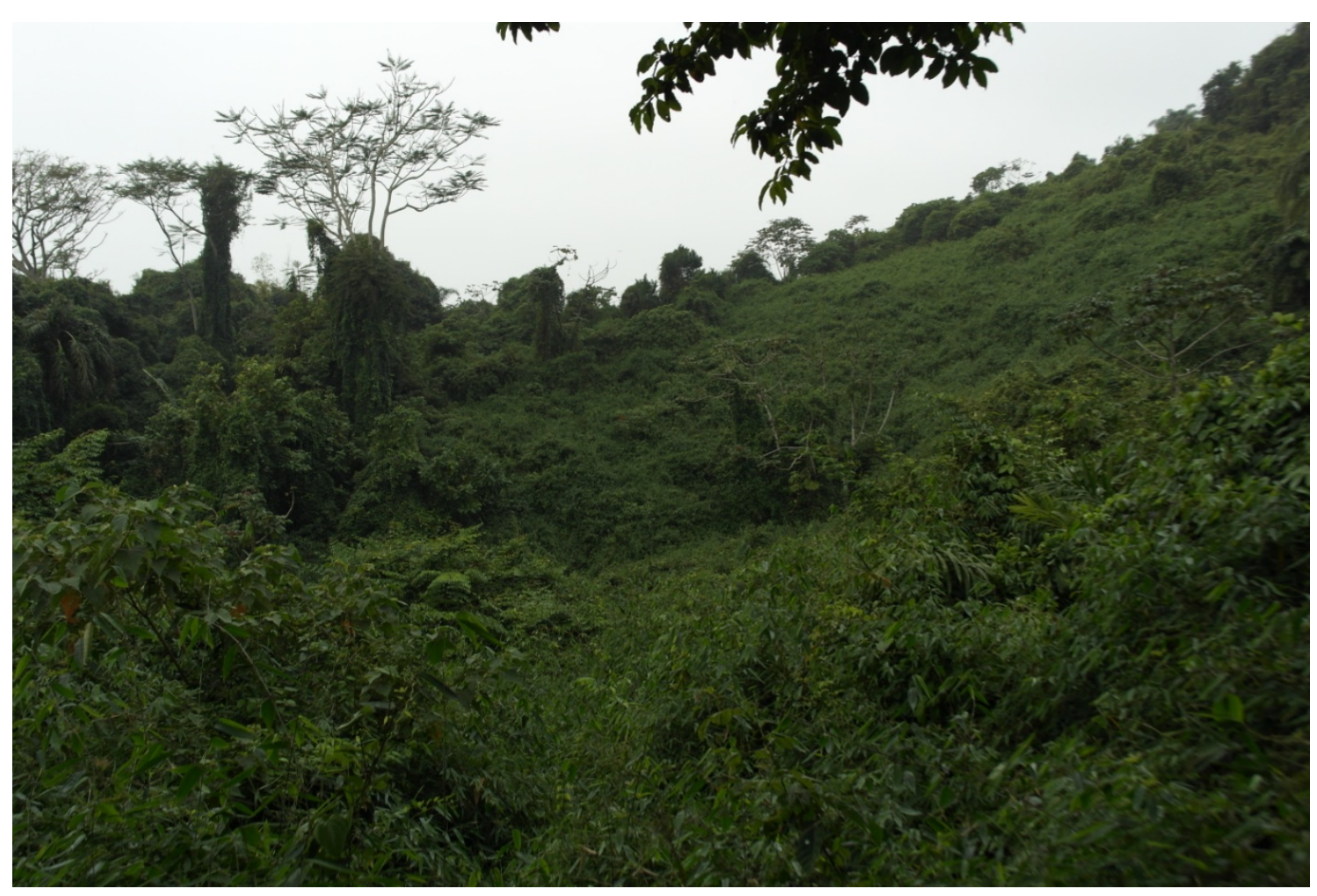

Figura 81. Fotografia de porção íngreme do terreno, com campos graminosos e árvores de menor porte. Créditos: Douglas Scaramussa Pereira 


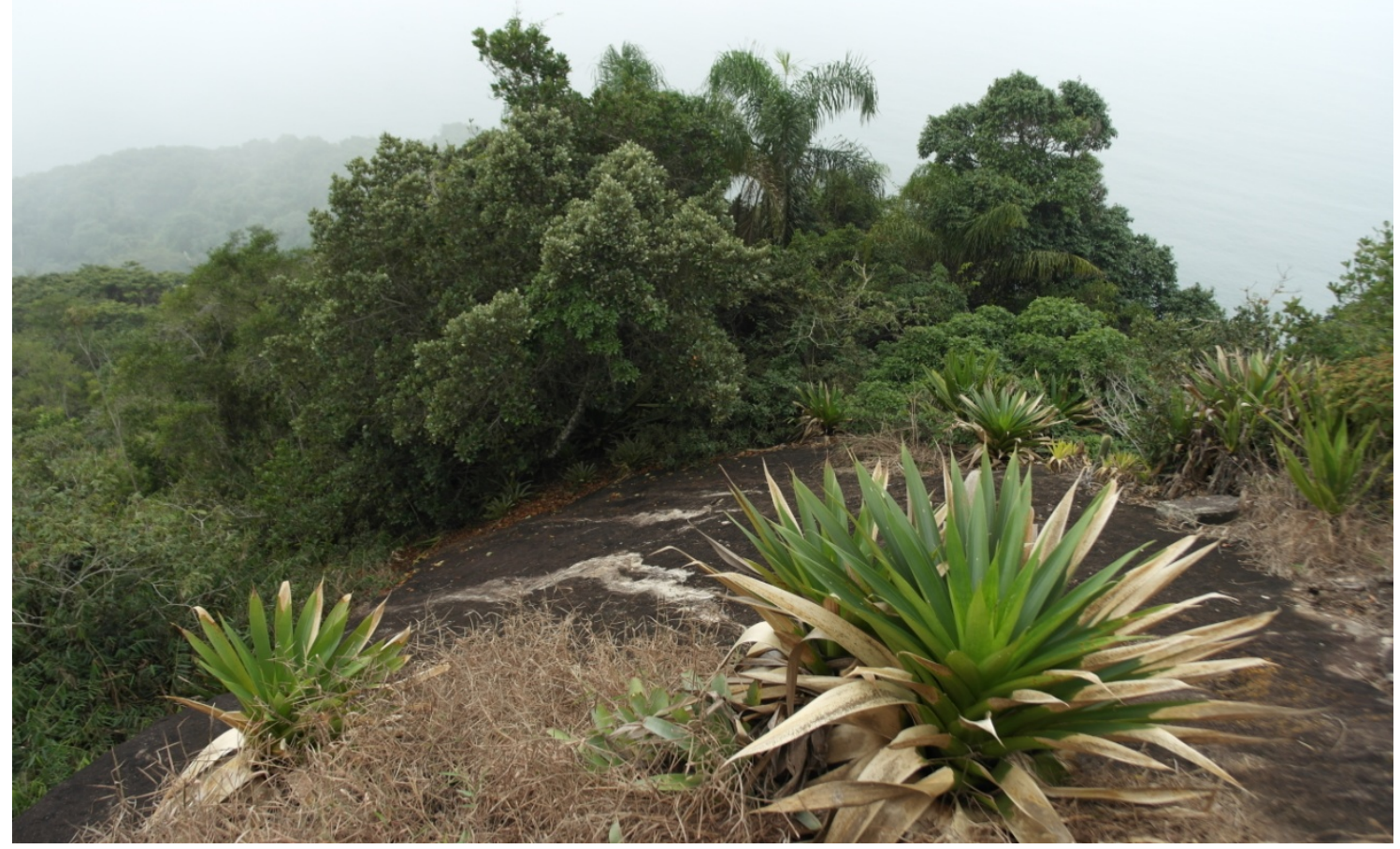

Figura 82. Fotografia de espécies rupícolas e saxícolas. Créditos: Douglas Scaramussa Pereira

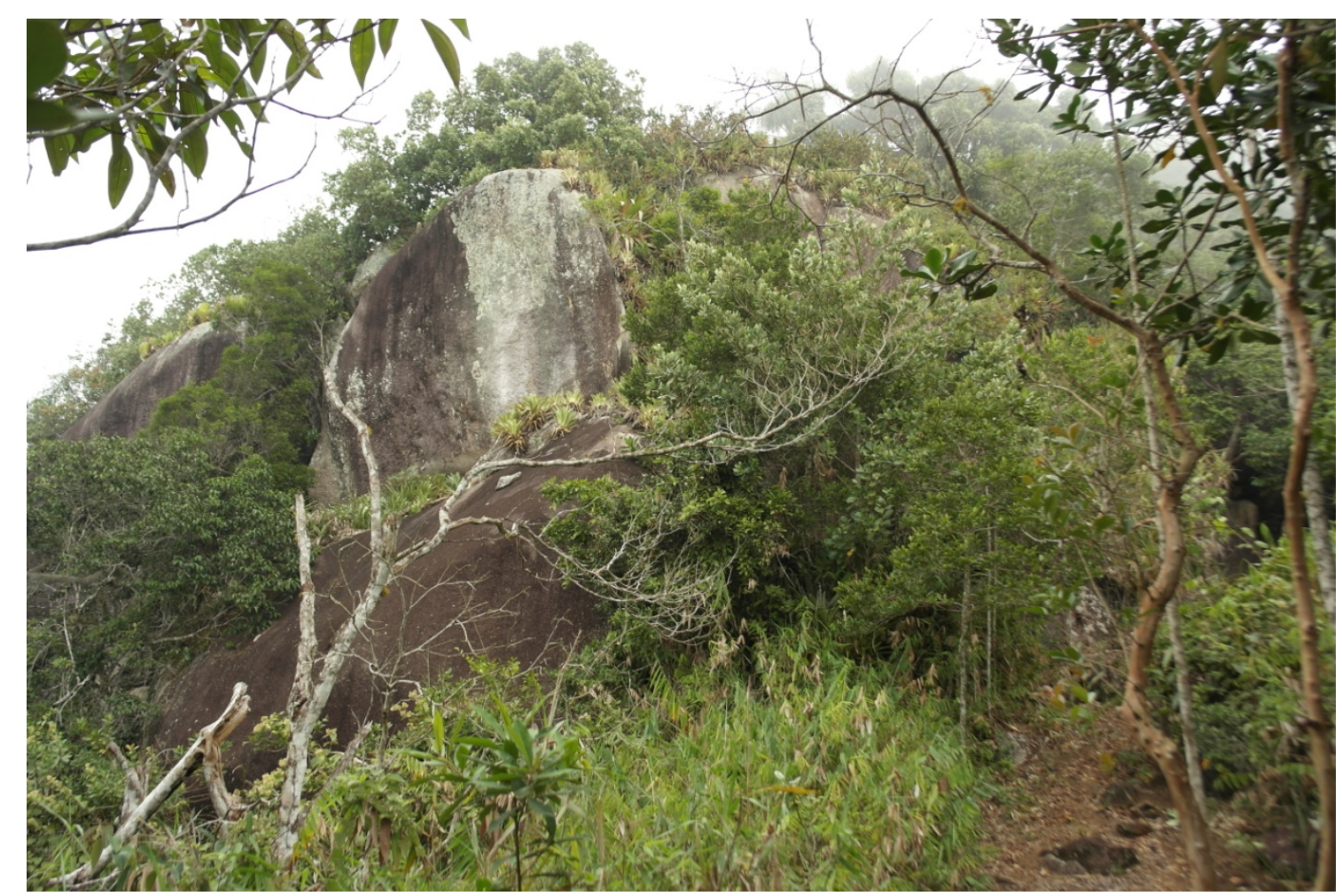

Figura 83. Fotografia de afloramentos de rocha nua, litófitos e fanerófitos já próximos ao cume da ilha. Créditos: Douglas Scaramussa Pereira 


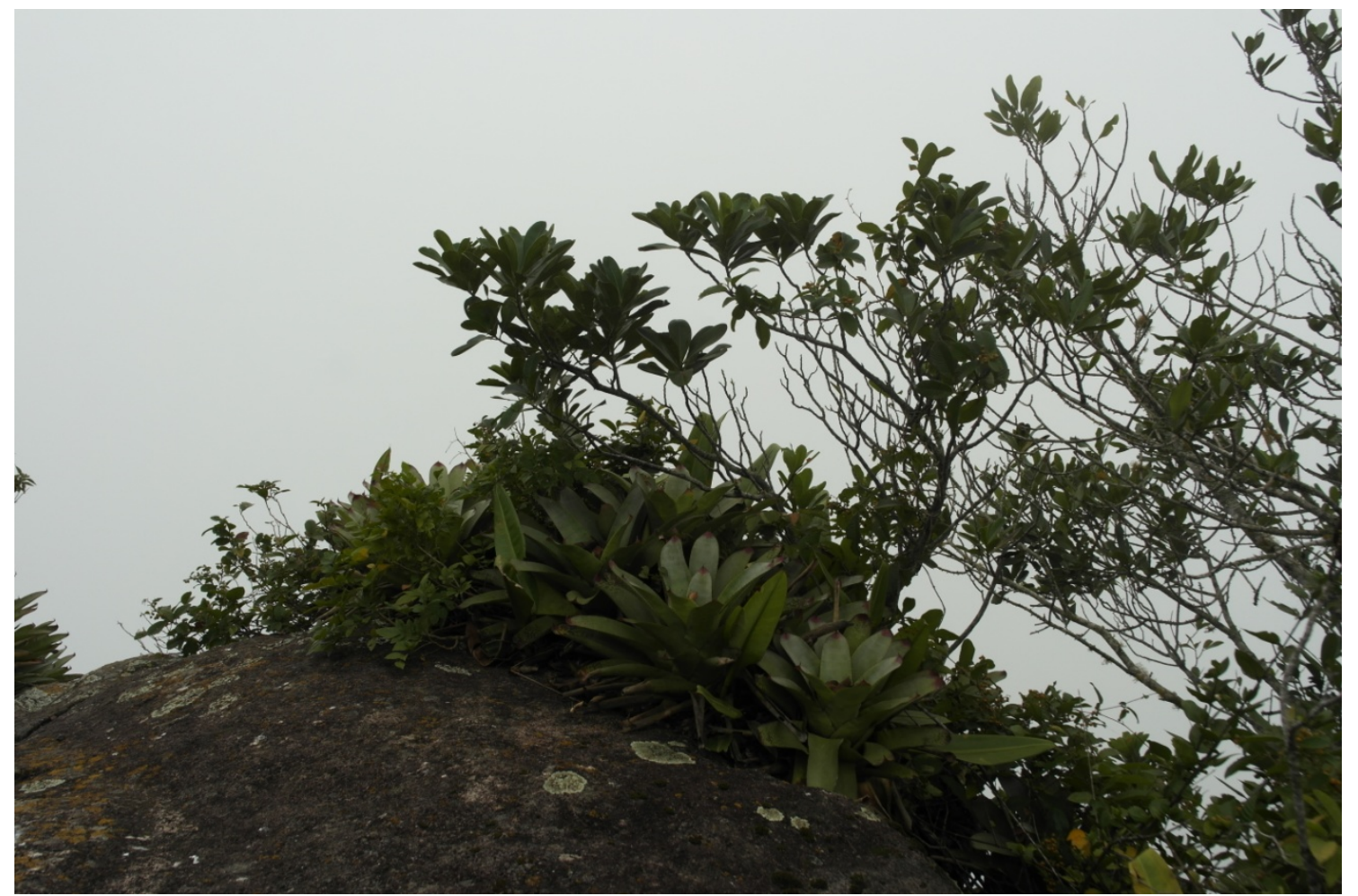

Figura 84. Fotografia do pontão úmido da ilha com bromeliáceas. Créditos: Douglas Scaramussa Pereira

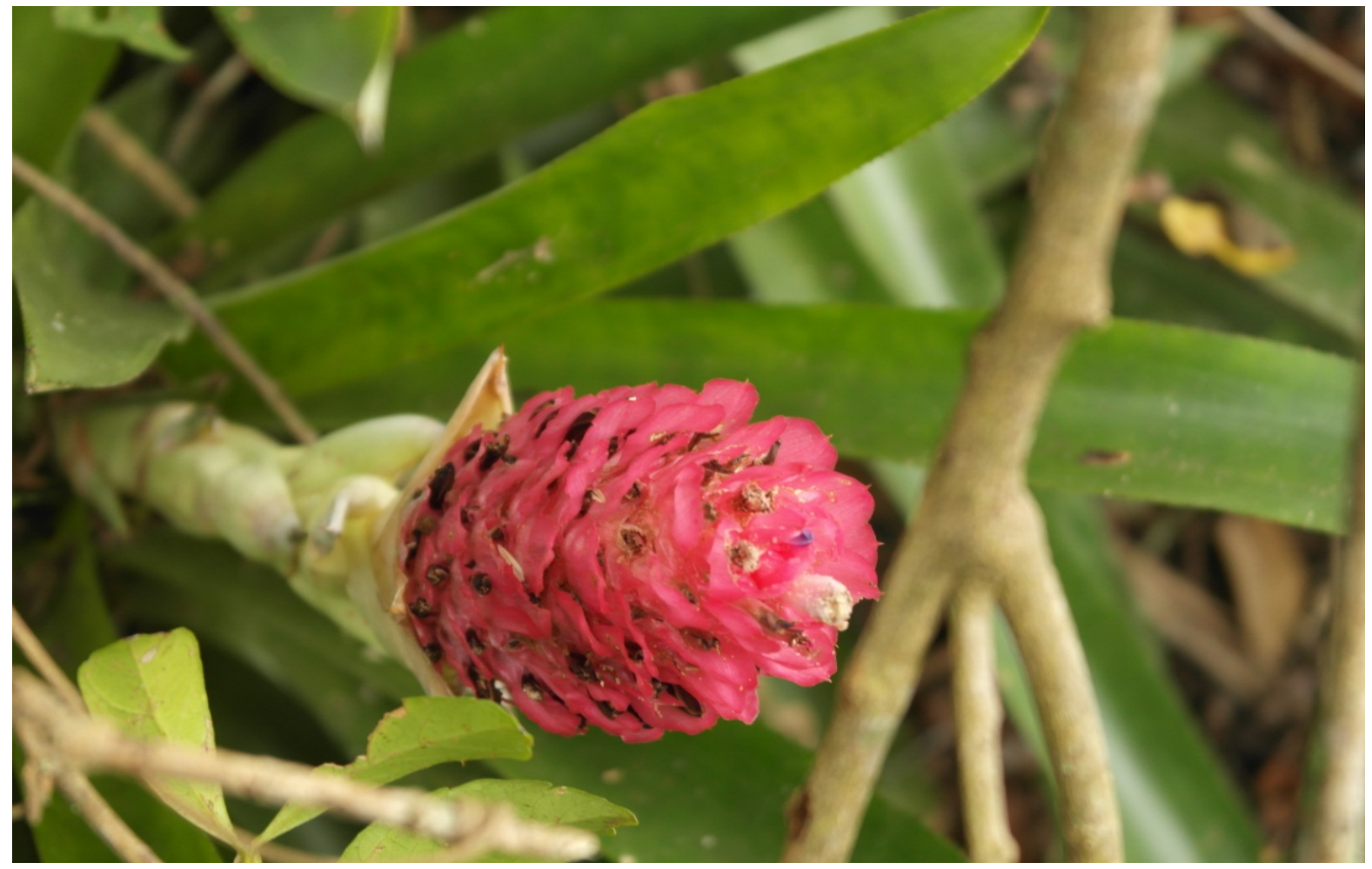

Figura 85. Fotografia de detalhe da flora do cume de Monte de Trigo. Créditos: Douglas Scaramussa Pereira 


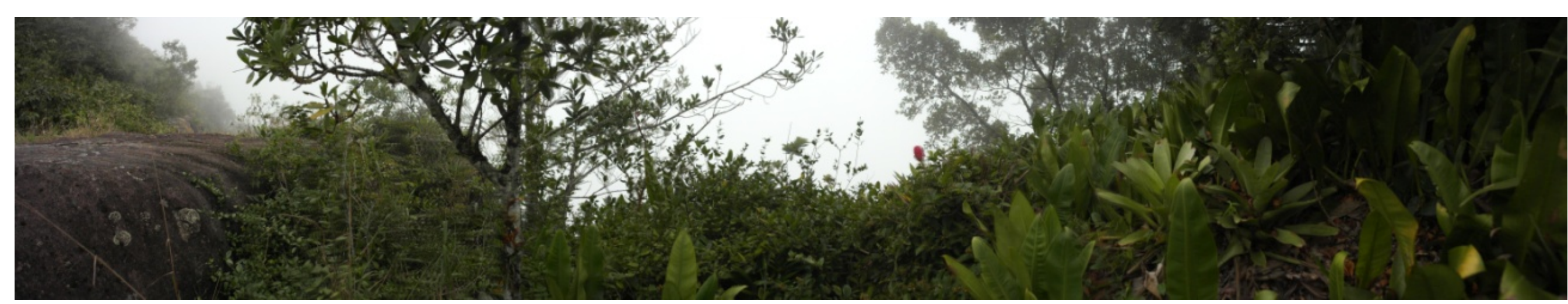

Figura 86. Fotografia da vegetação dos lajeados de altitude. Créditos: Douglas Scaramussa Pereira

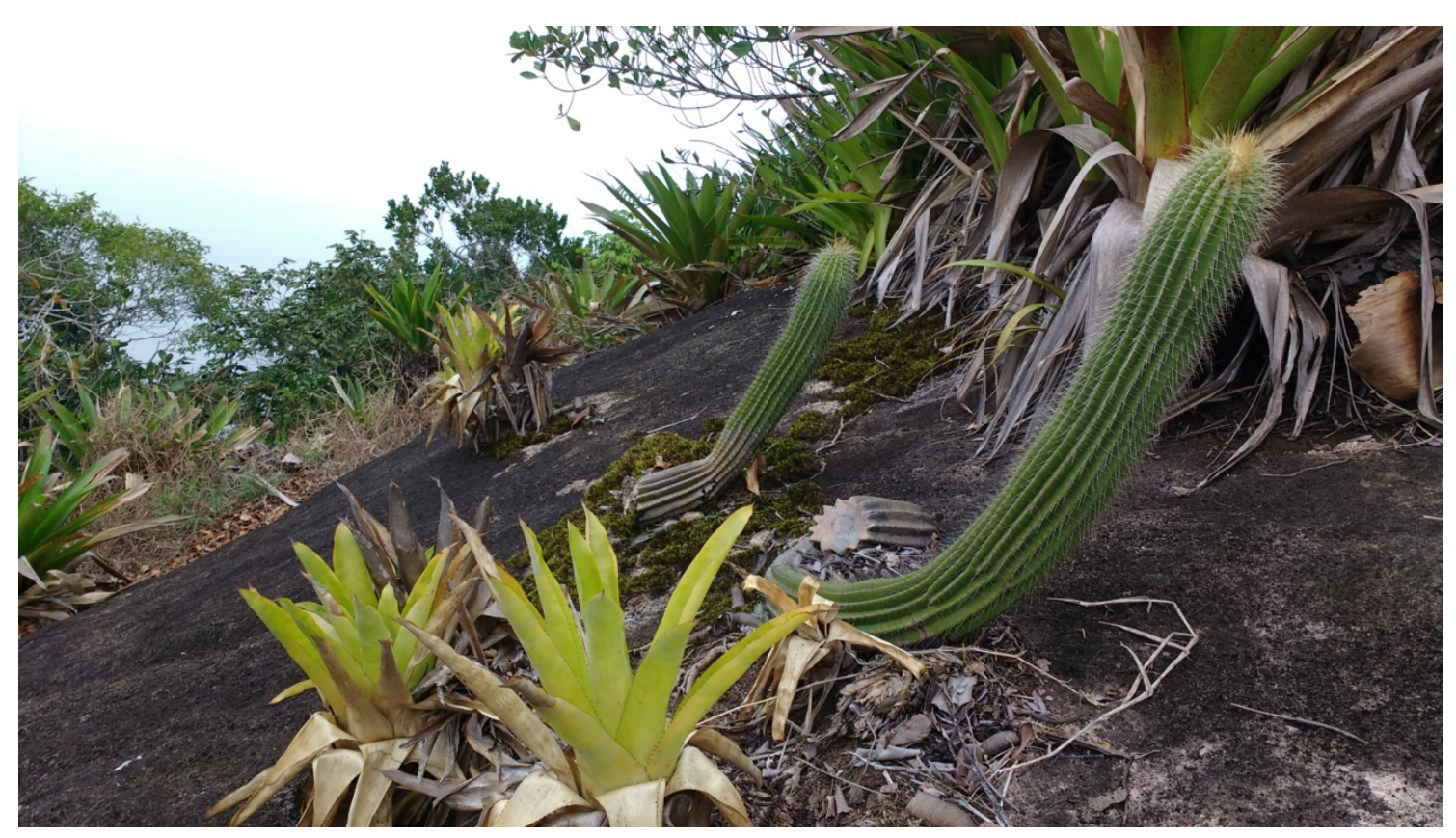

Figura 87. Fotografia de matacão próximo ao topo aguçado da ilha, com presença de cactáceas. Créditos: Douglas Scaramussa Pereira 


\section{Infraestrutura e situação socioeconômica}

Dentre as picadas de circulação ${ }^{310}$, há caminhos de certa densidade na Vila dos Pescadores, com a clara função de interligar as residências e os equipamentos de uso comunitário, assim como há trilhas em direção ao pico, às nascentes do costão do mar bravo e ao sul. Como verificamos em campo, dado o gradiente topográfico, as distâncias físicas raramente coincidem com as distânciastempo. A título de exemplo, numa caminhada empreendida por uma pessoa de condicionamento físico médio e sem limitações de locomoção conferidas pela idade ou por outra sorte de fatores, partindo-se da escola, são necessários 5 minutos para que se alcance a Ponta Negra; 8 minutos, o costão oriental adjacente ao campo de futebol e aos cultivos de cana-de-açúcar; outros tantos, o Portinho; 30 minutos, o Sítio de Lá; 35 minutos, as nascentes da vertente oriental; 50 minutos, isto é, quase uma hora cheia, o Pico de $289 \mathrm{~m}$, perceptivelmente, a mais íngreme das caminhadas.

Outras infraestruturas de relevância e interesse na Vila parecem ser as moradias (construções de madeira ou de material reciclado, cômodos diminutos, nem sempre contando com banheiros, eventualmente suspensas se declivoso o terreno onde se assentam), a escola (em alvenaria, com fossa séptica), o Portinho ou Porto do Imbiru (sem píer, com canoas puxadas mediante estiva de madeira), a Igreja Evangélica Assembleia de Deus (de alvenaria), o campo de futebol (utilizado pelos ilhéus e outros pescadores eventualmente aportados) e as antenas retransmissoras (localizadas no cume, funcionando por intermédio de placas solares pertencentes ao Iate Clube da Barra do Una). No Sítio de Lá, tem-se a capela de São Benedito, padroeiro da ilha ${ }^{311}$.

No levantamento acima, é de se ressaltar que não existem quaisquer infraestruturas de saúde (quiçá, há visitas nas épocas de vacinação), tampouco voltadas ao turismo. Sugere-se, pois, aqui o patamar socioeconômico dos monteiros. A educação está representada única e exclusivamente pela escola municipal, originalmente construída em 1969, ulteriormente desativada e tendo reiniciado suas atividades apenas em 1991, ofertando, com o auxílio de uma única docente, em classes multisseriadas, aulas que equivalem até o patamar do $5^{\circ}$ Ano do Ensino Fundamental. Assim, do ponto de vista formal, a escolaridade dos adultos é, por conseguinte, baixa, a despeito dos níveis diminutos de analfabetismo ${ }^{312}$. Dessarte, na ausência de postos de saúde, o que constitui fato grave nas ilhas de ocupação consolidada, como o é Monte de Trigo, os ilhéus necessitam transladar ao continente para consultas ou urgências médicas (sendo que, se vespertinas ou se, após sua conclusão, houver alteração no estado do mar, impõe-se como única opção o pernoite no continente). De mais a mais, podem-se enumerar outros fatos que justifiquem a viagem, quais 
sejam, a comercialização do pescado (à mercê do preço estabelecido pelo atravessador), a compra de produtos de uso essencial e a resolução de assuntos de âmbito civil (batizados, matrimônios, divórcios $)^{313}$. Eis a insularidade manifesta.

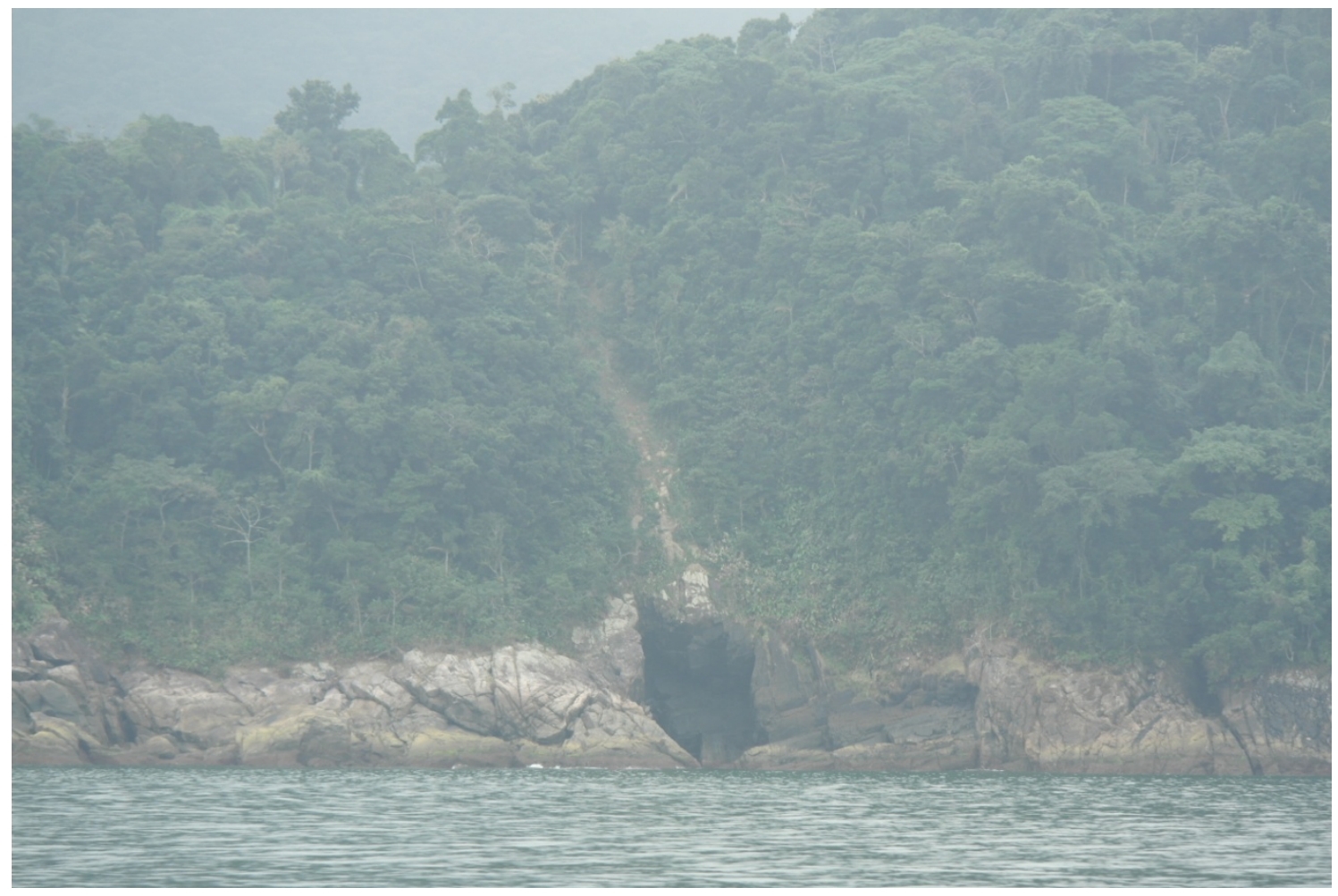

Figura 88. Fotografia de picada íngreme aberta próximo ao costão de Monte de Trigo. Créditos: Douglas Scaramussa Pereira

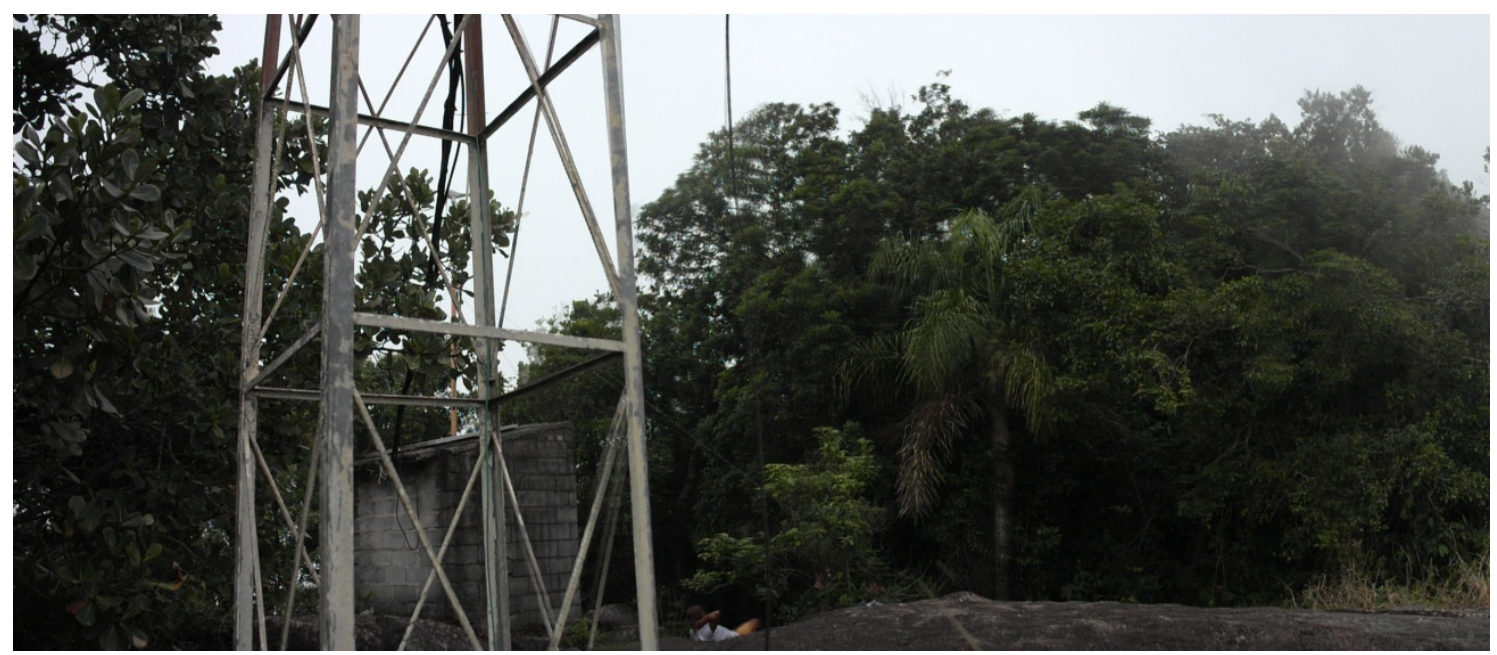

Figura 89. Fotografia da torre de transmissão localizada junto ao pico. Créditos: Douglas Scaramussa Pereira

313 PEREIRA et al., Op. cit., p. 33 


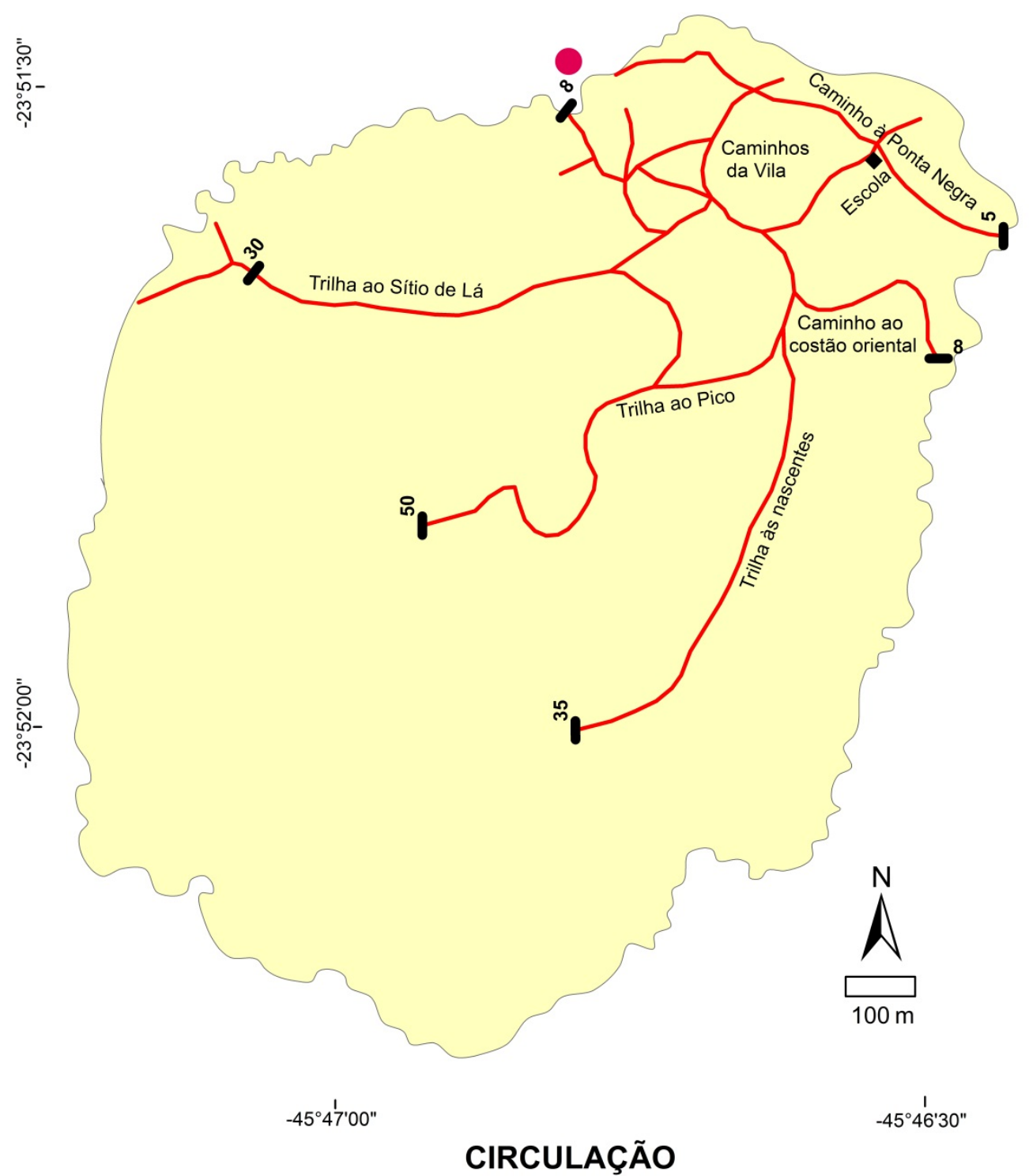

Porto do Imbiru

Trilhas e picadas

- Marcador de distância-tempo

Tempo necessário médio para uma pessoa comum percorrer, a pé, um trajeto com início na escola da Vila dos Pescadores até o ponto assinalado por esse marcador (em minutos)

Elaboração: Menegatto, 2017

Base de referência: Ortofotos - Emplasa (2011)

Figura 90. Mapa das trilhas e picadas de Monte de Trigo, com algumas marcações de tempo de deslocamento 


\section{Alma insular, vida comunitária}

As fontes secundárias parecem sugerir, e se verifica em campo, a religião é, sem dúvida, aspecto essencial da vida monteira. Notório o é, as formas de solidariedade grupal em torno dos festejos católicos de outrora (nas festividades a São Sebastião e ao santo padroeiro, cada uma com duração de três dias) vão, em paulatino, cedendo lugar ao respaldo mútuo diariamente manifesto pelos irmãos de culto. Isso porque a divisão entre catolicismo e evangelicalismo é fato recente. Não poderíamos deixar de citá-lo, os primeiros contatos estabelecidos para o trabalho de campo no Montão deram-se com os Pastores Adílson e Celso, que constituem referência de nicho comunitário significativo.

Conquanto os encontros da igreja compõem segmento importante no cotidiano do ilhéu, outras atividades, como a visita ao continente, a reunião noturna para assistir aos noticiários e às novelas, o banho próximo ao desembarcadouro e as partidas de futebol, ocupam assente frequência na vida desse lugarejo insular ${ }^{314}$.

Contrastando-se com as suprarreferidas infraestruturas físicas da ilha, há também as imateriais, que seja, aquelas que compõem o universo cultural caiçara. Nesse sentido, são disseminados, sem distinção de distribuição geográfica, os seguintes itens e hábitos alimentares: uma ou duas refeições-padrão (com arroz, feijão e farinha, comprados do continente, e peixe como item principal ou mistura, pescado no local e preparado frito ou ensopado), café-de-cana (café adoçado com garapa), paçoca de cará ou pão local (cará cozido e secado no pilão) ${ }^{315}$. 

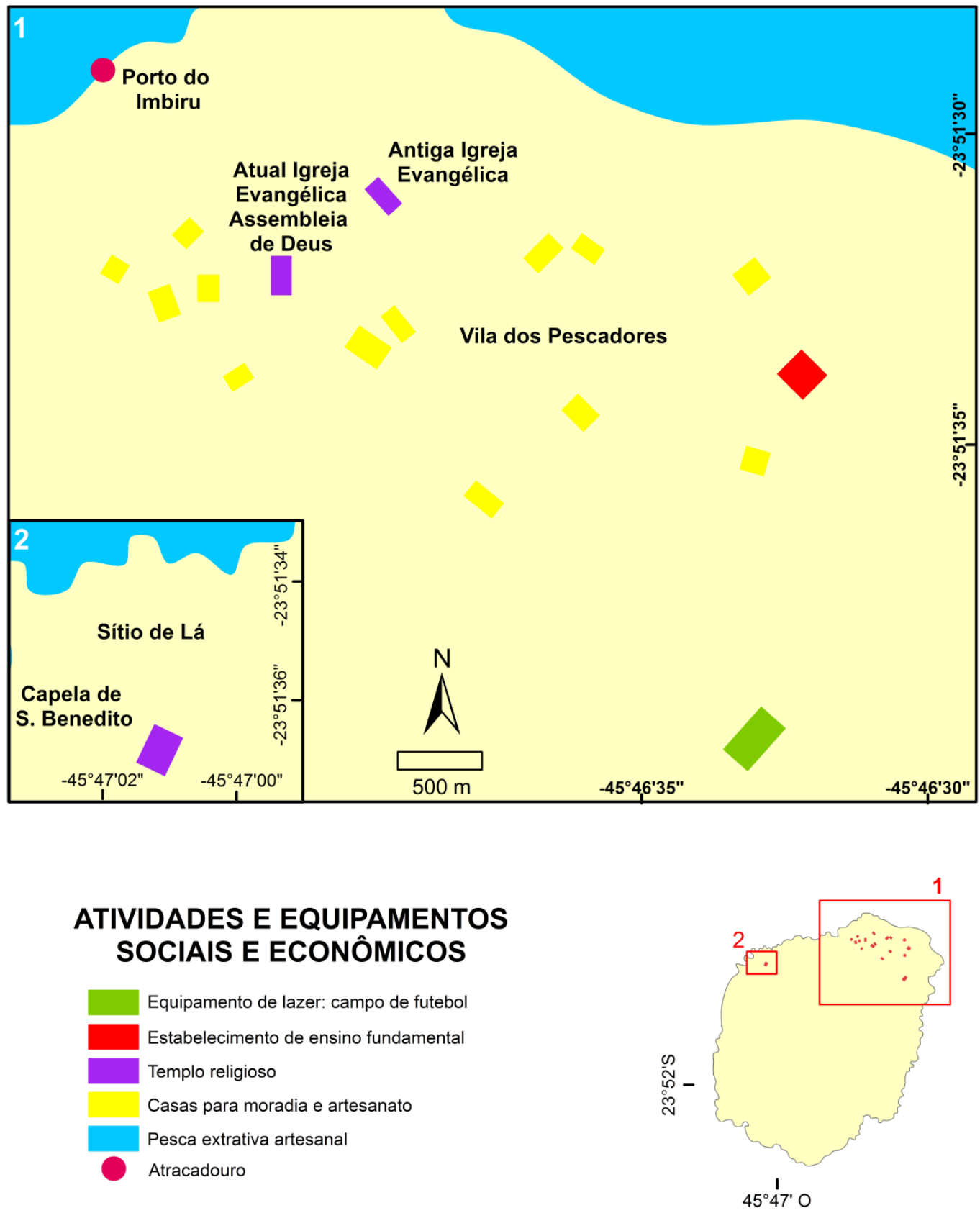

Elaboração: Menegatto, 2017

Base de referência: Ortofotos - Emplasa (2011)

Figura 91. Mapa de atividades e equipamentos sociais e econômicos de Monte de Trigo 


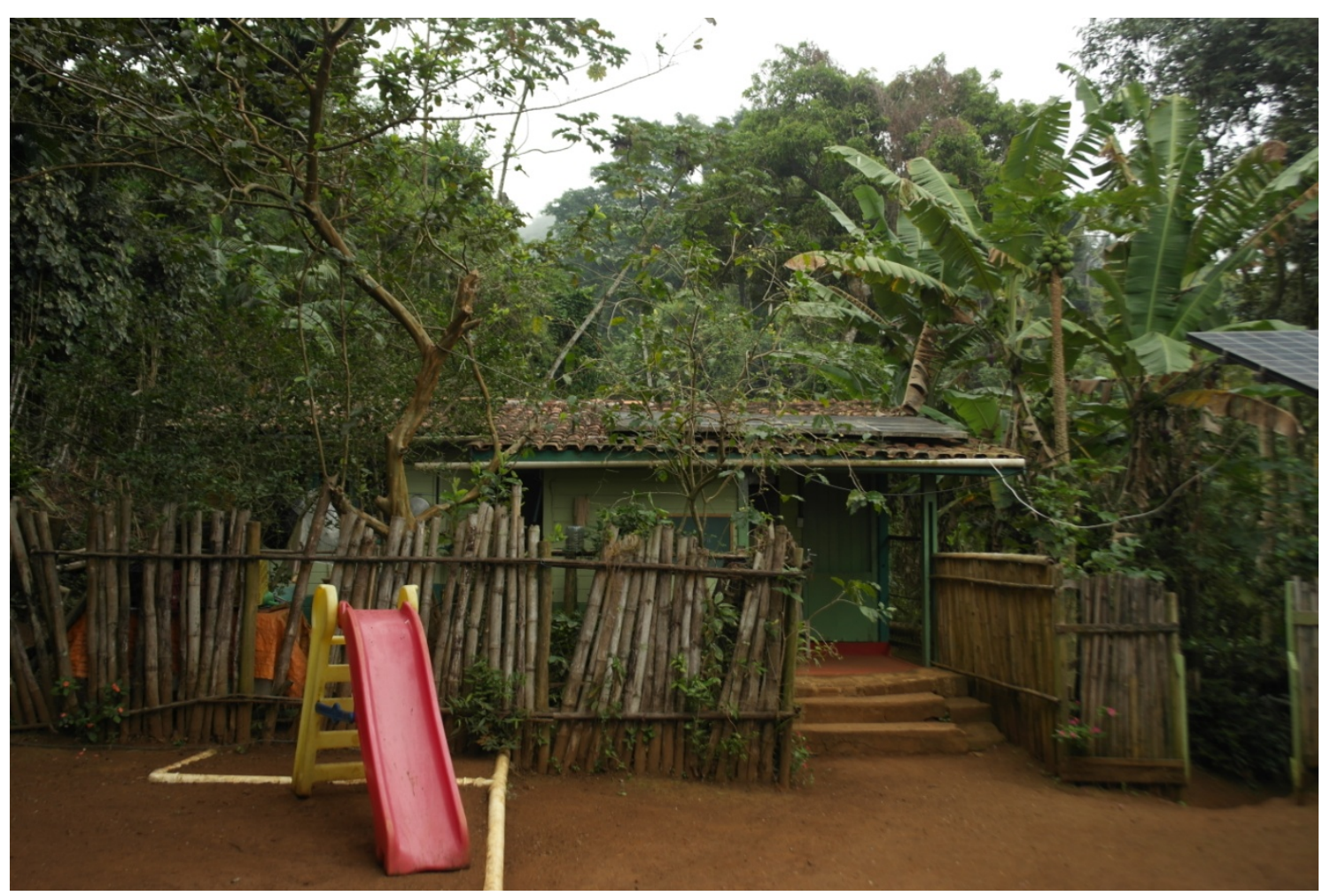

Figura 92. Fotografia da escola, na Vila dos Pescadores. Créditos: Douglas Scaramussa Pereira

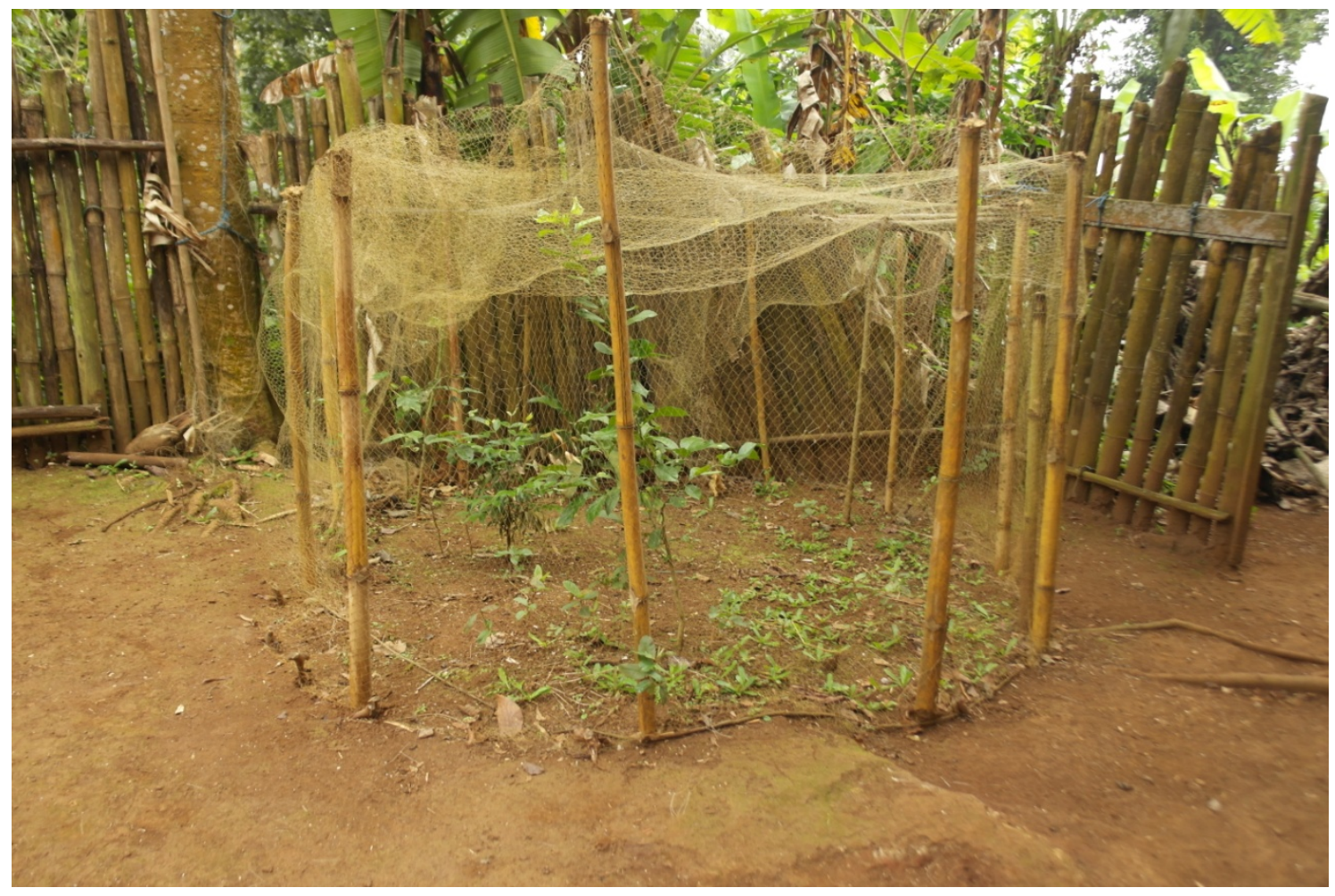

Figura 93. Fotografia de roça próxima à escola. Créditos: Douglas Scaramussa Pereira 


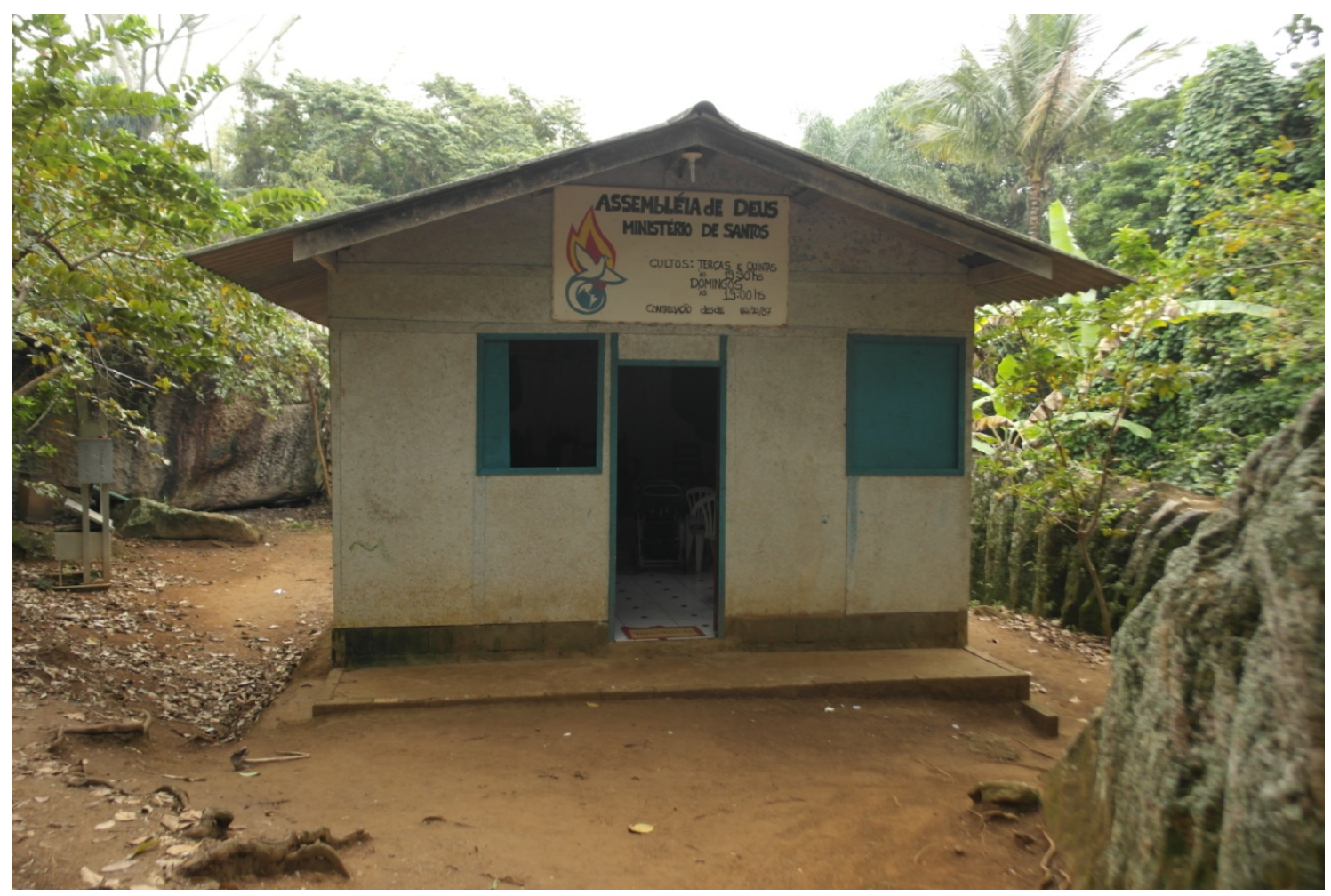

Figura 94. Fotografia da Igreja Evangélica Assembleia de Deus, única edificação religiosa de funcionamento corrente na Vila dos Pescadores. Créditos: Douglas Scaramussa Pereira

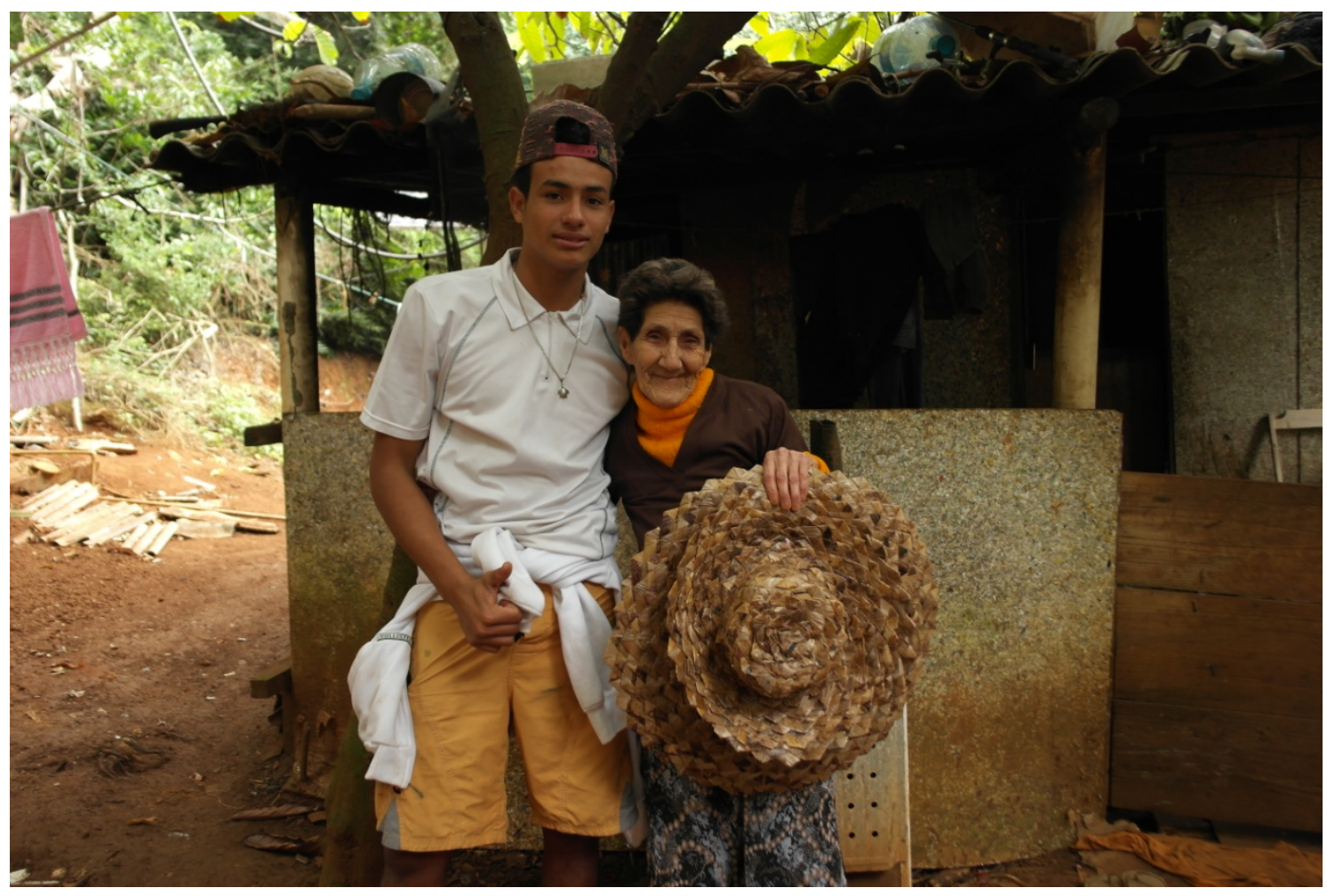

Figura 95. Fotografia dos monteiros. No caso, neto e avó. O chapéu e o tapete circular, feitos a partir da folha de bananeira, são exemplos do artesanato desenvolvido na ilha. Créditos: Douglas Scaramussa Pereira 
Se o assunto suscitado é o espírito comunitário, ora fruto da religião, ora produto do trabalho, que seja mercê do lazer, vale ressaltar que os monteiros possuem propriedades comuns, como é o caso da escola, dos remanescentes da roça de cana-de-açúcar, da floresta e dos víveres nela presentes, mas, tal como outras sociedades caiçaras, não são exatamente coletivistas. Cada um, pois, tem sua propriedade. Há, inclusive, posse pessoal de árvores frutíferas, mesmo daquelas plantadas em áreas comuns, e de pontos no desembarcadouro, constituindo, a valer, objetos de venda, aluguel e herança. Fato este, porém, sem qualquer prejuízo ou demérito às demonstrações cotidianas de ajuda mútua.

Deveras, é propriedade incontestável aquela constituída pela residência e área de entorno (quintal). São, contudo, raras as construções físicas criadas por mão humana capazes de estabelecer formalmente a segmentação dos terrenos, uma vez que as seções territoriais são mais ou menos compreendidas pelos moradores a partir de marcos divisórios naturais (córregos, rochas, árvores) ou já apropriados para o uso social (costão de desembarque). Mas, note-se, fato curioso, a maioria dos monteiros descende da mesma família (de sobrenome Oliveira) ${ }^{316}$, o que dá certo sentido comunal ao espaço organizado, conferindo certa fluidez a essa divisão aparentemente rígida. Geralmente, a propriedade com casa e pomar é herdada dos pais, passando de geração em geração ${ }^{317}$.

316 Consultar reportagens sobre Monte de Trigo na revista "Veja São Paulo" e no jornal "Folha de São Paulo". 317 CAROLINO, Op. cit., p. 64-66 


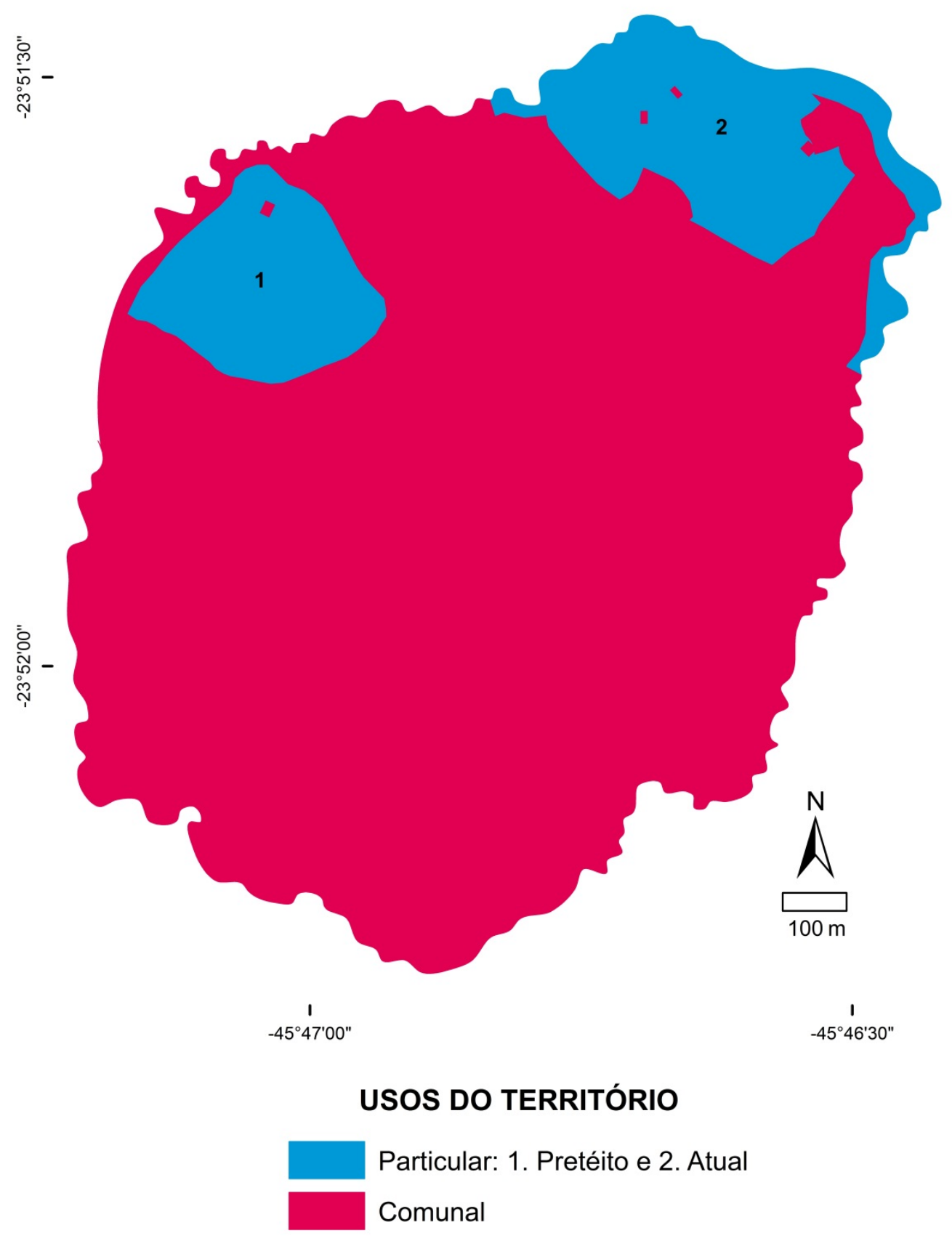

Elaboração: Menegatto, 2017

Base de referência: Ortofotos - Emplasa (2011) Fonte: Carolino (2010)

Figura 96. Mapa de usos do território em Monte de Trigo 


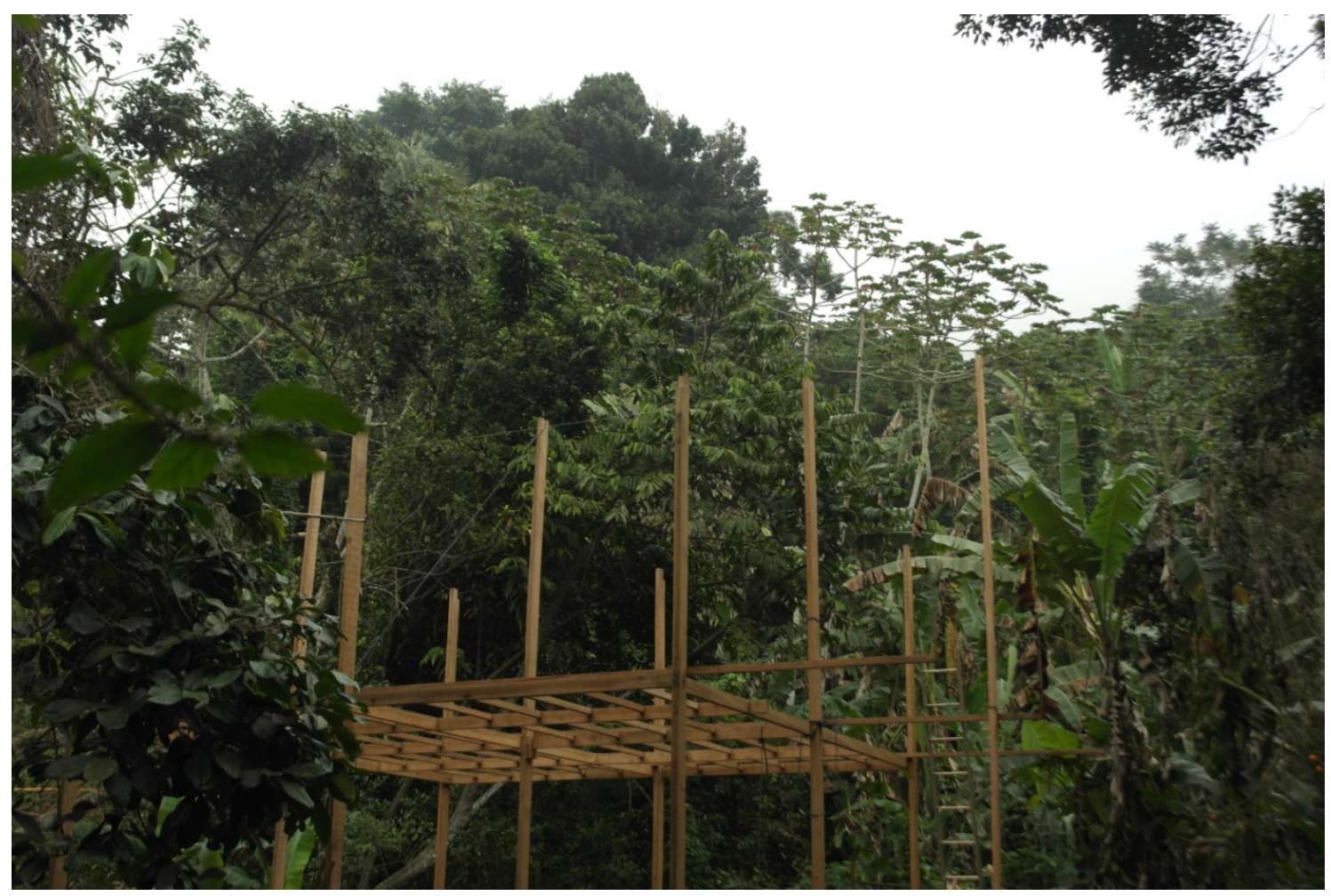

Figura 97. Fotografia de construção em madeira na Vila dos Pescadores. Créditos: Douglas Scaramussa Pereira

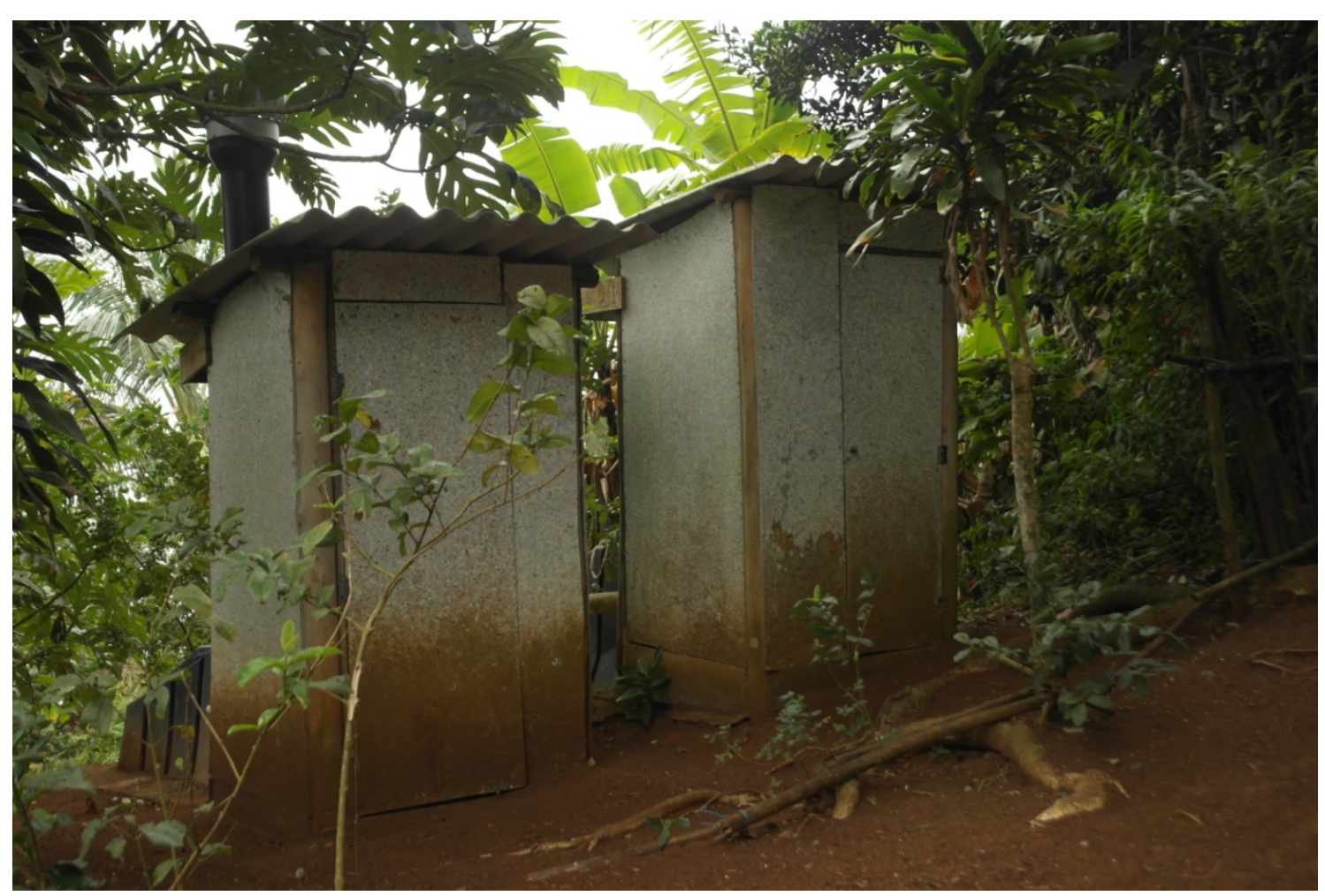

Figura 98. Fotografia de banheiros externos às moradias. Créditos: Douglas Scaramussa Pereira 


\section{Histórico da ocupação}

A ocupação ininterrupta da família Oliveira em Montão de Trigo parece remontar, pelo menos, dois séculos. Não obstante, registros arqueológicos demonstram sinetes de homens mais pretéritos. Há ossadas humanas tanto no topo da ilha como em toca da costeira (a Toca da Caveira), sendo as primeiras talvez de indígenas, dados os artefatos proximais encontrados (conchas de marisco e vasos de cerâmica), e as segundas resultantes de provável massacre promovido pelos corsários em suas incursões pelos litorais do sudeste brasileiro ${ }^{318}$. "Índios, piratas ou gente ruim", nas palavras dos ilhéus.

Há quem atribua o início do povoamento a uma espécie de mito de origem, no qual dois casais de irmão habitavam, cada qual, um costado da ilha e, uma vez em contato, relacionaram-se entre si, povoando o espaço monteiro. Mais factível, porém, parece-nos a versão oral coletada por Cardoso $^{319}$ : Antônio Pantaleão, Manuel e João aforaram a ilha junto à Igreja do Carmo, erigindo, em 1777, a construção onde hoje se assenta o desabitado Sítio de Lá. Com o gradual povoamento, a ilha transmutou-se numa paisagem organizada por duas centenas de moradores, que, pescadoresagricultores que eram, estabeleciam, com Bertioga e praias adjacentes, o comércio daquilo que era produzido na ilha ou nos seus mares circundantes.

Fatos anteriores são apontados pela Sociedade Amigos do Bairro do Una (SABU) ${ }^{320}$ : o Montão pertencia à Fazenda Una, concedida, em 1656, à família Vasconcellos por meio de uma carta de sesmarias, e, em 1866, vendida a Antônio de Goés Filho.

Finalmente, o século XX parece ter sido, nessa ordem de sucessão, o nascente e o poente do sucesso monteiro: momento primevo, o Sítio de Lá destacava-se pela aglomeração humana, sendo que seus habitantes, para suas pescarias, partiam rumo a plagas relativamente distantes, como Alcatrazes e a Laje de Santos. Com o desequilíbrio demográfico (alta taxa de masculinidade, sobretudo) e o patamar socioeconômico desvalorado, Monte de Trigo experimentou, adiante, o deslocamento interno do Sítio de Fora para a Vila dos Pescadores e o êxodo de vários moradores.

\section{Perfil da população}

Com base no Mapeamento de Unidades Territoriais e no Censo Demográfico de 2010, ambos realizados pelo Instituto Brasileiro de Geografia e Estatística (IBGE) ${ }^{321}$, sabe-se que Monte

318 BARROS, Op. cit., p. 138

319 CARDOSO, 1996, p. 42

320 SABU, 1983 apud CAROLINO, Op. cit., p. 47-51

321 Para mais informações, consultar, no caso do Mapeamento de Unidades Territoriais, $<$ http://www.ibge.gov.br/home/geociencias/cartografia/default_territ_int.shtm?c=3>, e, para os dados do Censo, 
de Trigo assenta-se, escala por escala, na Região Metropolitana do Vale do Paraíba e Litoral Norte (RMVPLN), mesorregião do Vale do Paraíba Paulista, microrregião de Caraguatatuba, município de São Sebastião, distrito e subdistrito de Maresias, setor censitário único de número 0042, com limites definidos pela ilha e orbitado em torno da Vila dos Pescadores, um lugarejo rural. Sua população em torno de 50 habitantes (mais especificamente, 49 pessoas à época), distribuída por 12 residências fixas, possui um perfil mais que heterogêneo, desigual: 31 homens, 18 mulheres; 4 crianças de 0 a 4 anos, todas brancas; 12 crianças de até 10 anos de idade, todas com registro de nascimento; 38 alfabetizados dos 45 habitantes com 5 anos ou mais; 26 católicos, 24 evangélicos; em 8 domicílios, os homens são os únicos responsáveis pela renda familiar; em 4, a mulher possui corresponsabilidade.

\section{A ilha: território de quem?}

A termo, os instrumentos jurídicos que recaem sobre a ilha são inúmeros. A licença para os ilhéus morarem no Montão está asseverada por um Termo de Autorização de Uso Sustentável (TAUS), expedido pela Secretaria do Patrimônio da União (SPU) ${ }^{322}$ em benefício das comunidades tradicionais ${ }^{323}$. Ademais, Monte de Trigo é, concomitantemente, "área de proteção permanente" (artigo 156 da Lei Orgânica do Município de São Sebastião), "área sob proteção especial” (artigo 33 do Plano Diretor do Município de São Sebastião), "recurso ambiental” juntamente ao mar que o circunda (artigos 2, inciso IV, e 44 da Lei Federal no 9.998, de 18 de julho de 2000), "bem da União" tal qual o mar territorial (artigo 20, incisos IV e VI, da Constituição Federal de 1988), "espaço especialmente protegido" no Estado (artigo 196 da Constituição Estadual de 1989), "bem imóvel da União" (artigo 1, idem “d”, do Decreto-Lei Federal n 9.760, de 5 de setembro de 1946), parte do Setor 3 (Ypautiba) da Área de Proteção Ambiental (APA) Marinha Litoral Norte (artigo 2, inciso II, do Decreto Estadual $\mathrm{n}^{\mathrm{o}} 53.525$, de 8 de outubro de 2008), terra emersa inclusa no mar territorial (artigo 3 da Convenção das Nações Unidas sobre o Direito do Mar, em vigor, no Brasil, por intermédio do Decreto Federal $n^{0} 1.530$, de 22 de junho de 1995) e "área natural tombada" (artigo 1 da Resolução SC 40 do Conselho de Defesa do Patrimônio Histórico, Arqueológico, Artístico e Turístico do Estado de São Paulo, de 6 de junho de 1985).

coletados em 2010 e sistematizados em 2015, <http:/www.ibge.gov.br/home/estatistica/populacao/ censo2010/resultados_gerais_amostra/resultados_gerais_amostra_tab_uf_microdados.shtm>.

322 Para ler o TAUS na íntegra, acessar a página 114, Seção 3, do Diário Öficial da União (DOU), de 23 de outubro de 2012.

323 Mais informações estão disponíveis em matéria do Jornal "Folha de São Paulo": $<$ http://www1.folha.uol.com.br/multimidia/videocasts/2012/01/1028233-caicaras-ganham-ilha-no-litoral-norte-desp-veja-video.shtml>. 
B. Propostas de modelização 


\section{MONTÃO DE TRIGO E SUAS ESTRUTURAS FUNDAMENTAIS}

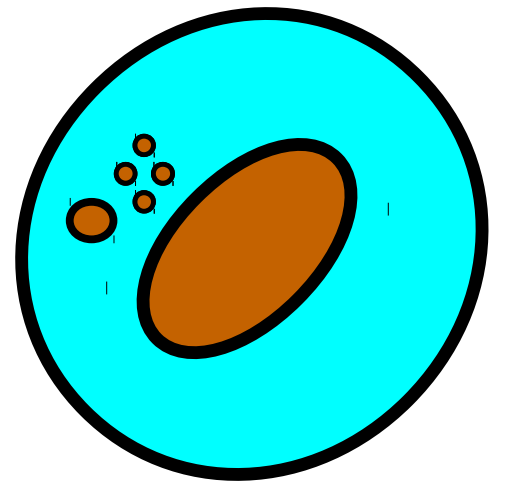

Quase arquipélago na diferenciação terra-mar:

Ilha Montão de Trigo como único ecúmeno;

Penetração da influência marítima na vertente do mar bravo:

córregos e concavidades de dissecação como facilitadores

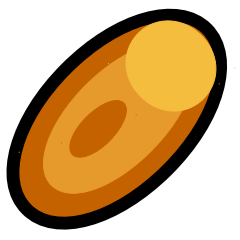

Unidades fisiográficas, compartimentação edáfica e ambientes topoclimáticos: verticalidade do costão rochoso e do pontão úmido de campos abertos; horizontalidade relativa do platô máfico; inclinação acentuada de vertentes convexas sieníticas com floresta assentada sobre cambissolos e neossolos litólicos
Laje e escolhos marinhos como pontos de pesca e referência geográfica

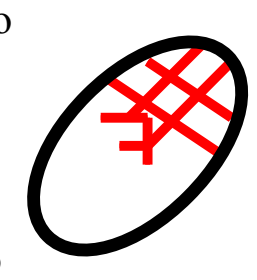

Ligações internas: trilhas e picadas

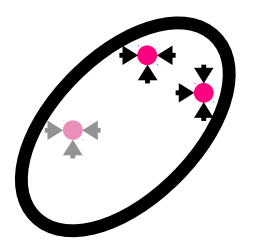

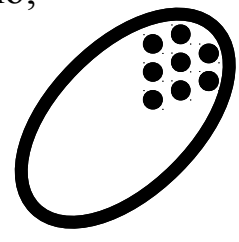

Dinâmica territorial: conquista do direito de uso da terra por uma população rarefeita e em declínio

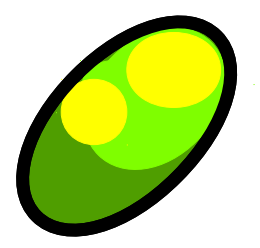

Gradações do selvagem, graus de antropização:

floresta ombrófila densa submontana e campos de samambaias e gramíneas (relictos) no interior; capoeira intergrades; ambientes antrópicos com pomar, roça remanescente $\mathrm{e}$ cultivo de cana-deaçúcar

Centralidades intrainsulares: marcas na paisagem de um antigo centro no

Sítio de Lá; pontos de atual referência comunitária (igreja, campo de futebol, escola com roça) Elaboração: Menegatto, 2017

Figura 99. Modelos gráficos de análise e síntese retratando a ilha Monte de Trigo 


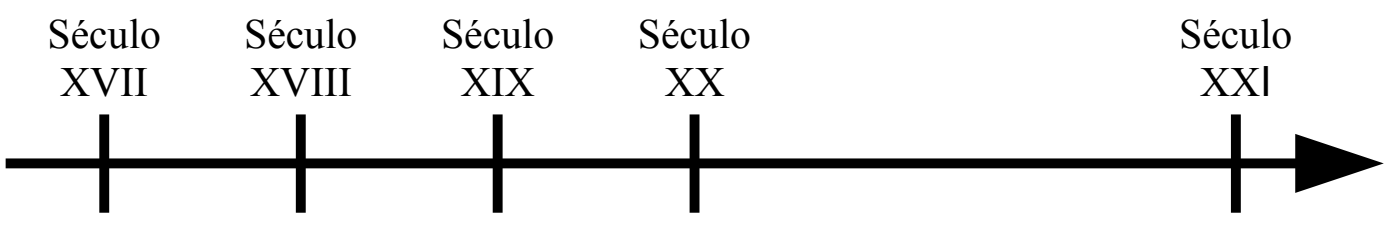

Distintivo e densidade do povoamento humano
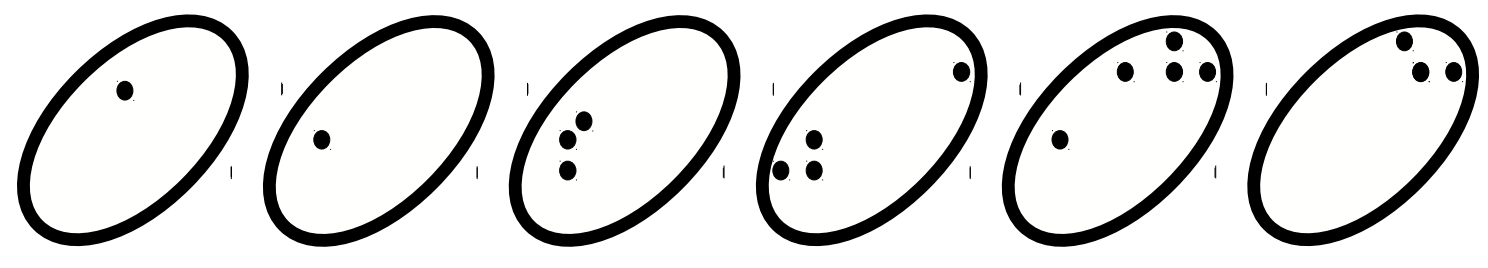

Centralidades intrainsulares
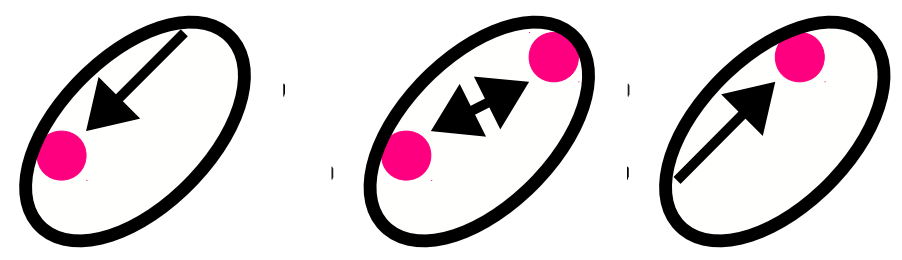

Níveis de afastamento do litoral ( centro geométrico, periferia da colonização; o fator maritimidade)

Patamares da antropização
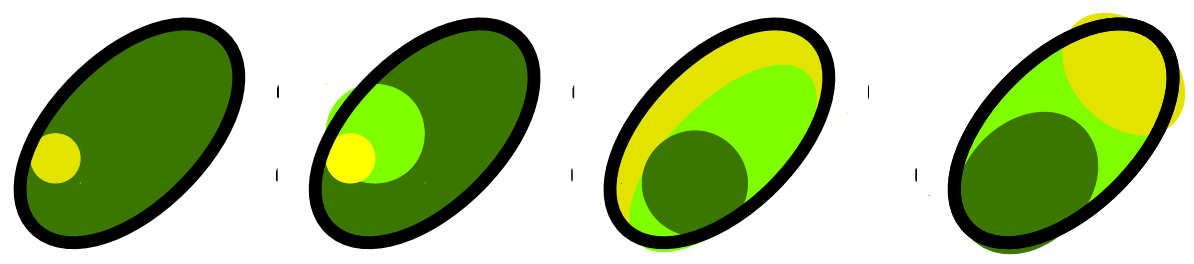

Eutopia insular pretérita, utopia além-mar contemporânea
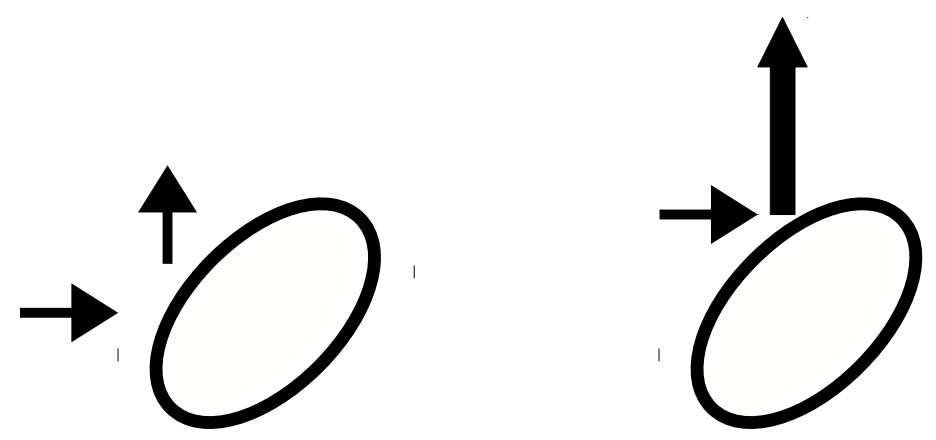

Sinapses intestinas
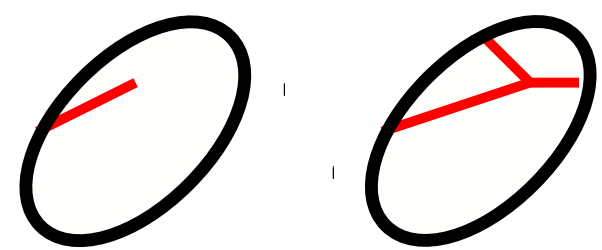

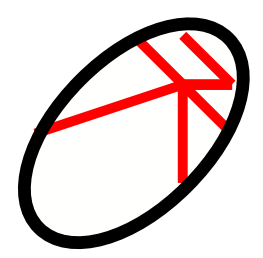




\section{CONSIDERAÇÕES FINAIS}

“Os mapas são representações que obedecem a um princípio de transposição analógico, do referente para a representação. Isto é: (re) apresentam os objetos segundo as mesmas disposições, relações e dimensões pelas quais elas são percebidas na realidade" ${ }^{324}$. Deveras, não intentando imitar e, sim, reproduzir segundo aquilo que se considera estruturante para aquele espaço, o mapa possui potencial de modelo. Sugere suprimindo.

Outrossim, se o mapa representa um espaço, o modelo gráfico, pós-cartográfico que é, em sua especificidade, anseia transmitir a forma espacial por excelência. Não simplesmente o espaço físico banal, não tão somente o espaço geométrico representacional; porém, a sério, o espaço terrestre onde o homem trama sua vida, o espaço humano, de significados, manifesto no nível mais superficial da crosta telúrica. Entretanto, nenhum cartógrafo é capaz de captá-lo em sua integralidade, já que, por definição, todo modelo da realidade tem sua utilidade na seleção, isto é, na eliminação. Quem seleciona, elimina, assim como o que é, é isto, e não aquilo. São, antes, aproximações da forma espacial que se é possível esboçar.

A forma ilha, definida pelos conceitos de insularidade e amparada nas noções de maritimidade, litoralismo, ilheidade e condição arquipelágica, é já um aspecto possível do espaço social teluricamente manifesto ou do espaço terrestre socialmente apropriado. Sendo, contudo, categoria do ser geográfico, sua complexidade parece afastá-la da representação. Para persegui-la, para dar-lhe forma, roupagem conceitual, é necessário modelá-la. Daí a modelização gráfica.

Os resultados da pesquisa não são senão periféricos à essência das ilhas. Constituem, pois, conjecturas seletivas que a Geografia, ao longo de sua antiga história de pensamentos e de suas mais recentes empresas em termos de modelos coremáticos, foi capaz de produzir sobre o espaço insular. Nesse contexto, os modelos gráficos conferem visualidade à forma abstrata insular, combinando coremas, estruturas elementares do espaço. E, assim como há uma gramática semiótica para os coremas dos espaços genéricos, é-se praticável esmiuçar um quadro coremático para a realidade das ilhas.

De fato, uma miríade de possibilidades parece orbitar em torno do centro conceitual em questão. Destarte, em vez de respondermos o que é uma ilha, optamos por demonstrar o que uma ilha pode ser, ou melhor, o que tem a oferecer. Como exórdio da análise, buscamos reconhecer, na realidade insular ideal, traços do isolamento, da quase presença impositiva do mar, da exiguidade espacial, do endemismo, do confrangimento territorial, da identidade imposta pelos limites da orla. Isso já é, aliás, sugerido pelos estudiosos desde o determinismo geográfico até a análise espacial, 324 FONSECA, Op. cit., p. 230 
entrecortados pelos paradigmas do possibilismo, da conservação ambiental e, mesmo, da ciência humanística. Mas as manifestações concretas na superfície do globo auxiliam-nos a expandir os horizontes da análise no sentido de destinar-lhe criticidade e, portanto, fornecer-lhe um sem número de reservas capaz de deixá-la a salvo duma simplificação tentadora que, do essencial, mais elimina que seleciona. A termo, esse percurso analítico depara-se com coremas de naturezas diversas, e é nessa multiplicidade de manifestações que, precisamente, reside o imperativo de estudos ulteriores a este e a outros trabalhos. Dentre elas, citam-se as ilhas-capital, as localidades costeiras e interiores, os limites territorias intra e interinsulares, os Estados-ilha (uni-insularidades) e os Estados-arquipélago (multi-insularidades), os centros de comunicação arquipelágica (cada qual numa ilha), as disposições de um arquipélago (arcos insulares, aglomerados, lineamentos), as ilhas barreiras, os atóis, as costas de dispersão e de condensação, as redes de drenagem e as estradas como sinapses interiores, os ambientes topoclimáticos e as compartimentações edáficas e fisiográficas possíveis, as ilhas como antimundos (servindo a centros de detenção, paraísos ecológicos, lazaretos) ou como pontos nodais de uma rede de comunicação ou circulação, a gravitação de um conjunto de ilhas ao redor de outra ou de um continente, as sinapses arquipelágicas por intermédio de mares interiores, os graus de afastamento do litoral (hipoinsularidades e superinsularidades), os pontos de conexão com o mundo exterior (portos, cidades) e o comércio além-mar, a franja litoral como condição de unidade política e ilheidade, a diferenciação costa-interior, as inúmeras funções econômicas de uma ilha (agrícola, comercial, turística), o embate entre a rarefação demográfica ou biótica e a superpopulação, as dinâmicas de crescimento vertiginoso e de estagnação ou depressão (dilema dos Pequenos Estados Insulares em Desenvolvimento), a propagação da influência marítima segundo o relevo e as redes internas, o isolamento e a ligação com o continente por eventos históricos de ordem natural e social, o particularismo sociocultural e o endemismo, os tipos de povoamento insular (permanente, sazonal, ocasional), os vínculos entre terras emersas nas mais multímodas escalas. Pistas, enfim.

Como remate, a realidade monteira parece ter muito a ensinar. Com efeito, sua utilidade de estudo não se deu somente na perspectiva da aplicação de uma teoria coremática para as ilhas, mas e, sobretudo, de acordo com o rico universo de estruturas e dinâmicas que a ilha parece encerrar. $\mathrm{O}$ sol, a tropicalidade, o maciço magmático alcalino, o mar sempre à vista. Trunfos e adversidades à permanência dos monteiros no território a eles atado, seja pela tradição, seja pela necessidade. A esses fatores, somem-se a especulação imobiliária, o turismo, novas e velhas perspectivas jurídicas e políticas sobre a ilha, em especial, e o litoral paulista, em geral.

Em verdade, o habitante de Montão de Trigo é, concomitantemente, caiçara e monteiro, identidade que lhe é, em certo sentido, complementar e, em outro, contraditória. Pois, como 
monteiro, ele tem amor à sua terra e, pela pesca e pela religião, parece conservar um pouco da vida comunitária que ainda lhe resta. Não obstante, como caiçara, ele não está sozinho - nem ele, nem sua comunidade; é, mormente, mais um dentre tantos moradores tradicionais do litoral paulista que, na busca pela diversificação de suas atividades, quer queira, quer a isso seja pressionado, elege a utopia do além-mar em detrimento da eutopia insular. De mais a mais, se assim o faz, sua ilheidade nunca é extinta por completo, uma vez que é dela que vem o nutriente cultural e psicológico para definir-se, segundo sua situação ou posição social, como sujeito do mundo ou, ao menos, no mundo. 


\section{REFERÊNCIAS}

\section{A. BIBLIOGRÁFICAS}

ALMADA E SANTOS, A. C. V. A insularidade e as suas condicionantes económicas. O caso dos pequenos Estados insulares em desenvolvimento. 2011. 411 p. Tese (Doutorado em Geografia Humana) - Instituto de Geografia e Ordenamento do Território, Universidade de Lisboa, Lisboa, 2011. Disponível em: <http://repositorio.ul.pt/bitstream/10451/5738/1/ulsd062207_td_Aquiles _Santos.pdf.> Acesso em 20/11/2014.

ARISTÓTELES. Tratados de Lógica. Volume I. Madri: Gredos, 1991. 390p. Tradução e notas: Quintín Racionero.

ARGENTIÈRE, R. Espaço, tempo e matéria. São Paulo: Pincar, 1958. 256 p.

AZEVEDO, A. Geografia do Brasil. Bases físicas, vida humana e vida econômica. São Paulo: Nacional, 1970. 316 p.

BABAU, M. C.; ALVES, L. M. SILVA, R. L. "Les conditions générales au Cap Vert”. In: ABREU, A. T. e SOARES, H. (org.). Desenvolvimento e pesquisa no longo prazo em Cabo Verde. Oeiras: Fundação Calouste Gulbenkian, 1983. p. 33-109.

BALTRUSIS, N.; MACHADO, C. B.; JESUS, D. A.; ROQUE, A. A. “Os impactos do anúncio da construção da ponte Salvador - Ilha de Itaparica no território da ilha”. Anais do CONINTER 3. Congresso Internacional Interdisciplinar em Ciências Sociais e Humanidades. Salvador (BA), UCSal, $\mathrm{n}^{\circ} 3$, v. 12 , p. 38-56, 2014. Disponível em: <http://aninter.com.br/Anais\%20CONINTER \%203/GT\%2012/03.\%20BALTRUSIS\%20MACHADO\%20JESUS\%20E\%20ROQUE.pdf>.

Acesso em 03/03/2017.

BARROS, L. F.. “A Ilha Monte de Trigo: impressões de viagens”. In: DIEGUES, A. C. (Org.). Ilhas e Sociedades Insulares. São Paulo: NUPAUB-USP (Núcleo de Apoio à Pesquisa de Populações Humanas e Áreas Úmidas Brasileiras da Universidade de São Paulo), 1997. p. 137-154. BERRY, B. J. "Approaches to regional analysis: a synthesis". Annals of American Association of Geographers. Whasington D.C., v. 54, n. 3, p. 2-11, 1964.

BERTIN, J. "Ver ou ler". Seleção de Textos. Associação dos Geógrafos Brasileiros (AGB). São Paulo, n 18, p. 45-62, ed. de maio, 1988. Tradução de Margarida M. de Andrade.

BOARD, C. "Os mapas como modelos". In: CHORLEY, R. e HAGGETT, P. (Org.). Modelos físicos e de informação em Geografia. São Paulo: Edusp, 1975. p. 139-184. Tradução de Arnaldo Viriato de Medeiros. 
BOUCHET, P. e GAY, J. "Les hauts de la Réunion conquis par lês loisirs". M@ppemonde. Avignon, v. 51, n. 3, p. 31-37, 1998. Disponível em: <http://www.mgm.fr/PUB/Mappemonde /M398/Bouchet.pdf>. Acesso em 18/09/2017.

BRASIL. Decreto-Lei Federal $\mathbf{n}^{\circ}$ 9.760. Brasília, 05 de setembro de 1946. Disponível em: $<$ http://www.planalto.gov.br/ccivil_03/decreto-lei/De19760.htm>. Acesso em 09/09/2015.

. Constituição da República Federativa do Brasil. Brasília, 05 de outubro de 1988. Disponível em: < http://www.planalto.gov.br/ccivil_03/Constituicao/Constituicao.htm>. Acesso em $08 / 09 / 2015$.

Lei Federal 9.998. Brasília, 18 de julho de 2000. Disponível em: <http://www. planalto.gov.br/ccivil_03/LEIS/L9985.htm>. Acesso em 04/09/2015.

. Secretaria de Patrimônio da União. Extrato de Autorização. Termo de Autorização de Uso Sustentável (TAUS) Coletivo de Área da União. Brasília, p. 114, Seção 3, Diário Oficial da União (DOU), de 23 de outubro de 2012.

BRICEÑO-GARMENDIA, C. M. e BENITEZ, D. A. "As infraestruturas em Cabo Verde: uma perspectiva continental". In: BANCO MUNDIAL. Africa infrastructure country diagnostic. Washington: BM, 2010. 30 p..

BROOKFIELD, H. Melanesia: a geographical interpretation of an island world. Londres: Methuen, 1971. $464 \mathrm{p}$.

BRUNET, R.. Le croquis de géographie régionale et économique. Paris: Société d'Édition d’Enseignement Supérieur 5, 1962. 249 p.

“Une épure de la Guadeloup”. M@ppemonde. Avignon, v. 4, n. 4, p. 24-25, 1986.

Disponível em: <http://www.mgm.fr/PUB/Mappemonde/M486/p24-25.pdf>. Acesso em 25/09/2016.

. La carte, mode d'emploi. Paris: Fayard/Reclus, 1987. 270 p..

. Le déchiffrement du monde. Théorie et pratique de la géographie. Paris: Belin, 2001. $402 \mathrm{p}$.

. “La Corse, région d’Europe”. M@ppemonde. Avignon, v. 76, n. 4, p. 1-16, 2004.

Disponível em: <http://mappemonde-archive.mgm.fr/num4/articles/art04407.pdf $>$. Acesso em $16 / 09 / 2016$.

BRUNET, R.; FERRAS, R.; THÉRY, H. (Org.). Les mots de la géographie. Dictionnaire critique. Montpellier/Paris: Reclus/La Documentacion, 1993. 518 páginas.

BRUNHES, J. Geografia humana. Rio de Janeiro: Fundo de Cultura, 1962. 507 p. Tradução de Ruth Magnanini. 
CALMONT, A. e VASSOIGNE, C. "Guadeloup, Martinique, Guyane: des espaces tropicaux entre insularité et continentalité”. M@ppemonde. Avignon, v. 54, n. 2, p. 10-14, 1999. Disponível em: $<$ http://www.mgm.fr/PUB/Mappemonde/M299/Calmont.pdf $>$. Acesso em 25/09/2016.

CANET, G. e RAISZ, E. Atlas de Cuba. Cambridge (Massachusetts): Harvard University Press, 1949. $55 \mathrm{p}$.

CARDOSO, E. S. Vitoreiros e monteiros: ilhéus do litoral norte paulista. 1996. 78 p. Dissertação (Mestrado em Geografia Humana). Faculdade de Filosofia, Letras e Ciências Humanas, Universidade de São Paulo, São Paulo. 1996.

. "Pesca e trabalho insular em Vitória e Monte de Trigo - Ilhas do litoral norte paulista". Okara: Geografia em debate. João Pessoa, v. 6, n. 1, p. 50-59, 2012. Disponível em: $<$ http://www.okara.ufpb.br>. Acesso em 24/09/2015

CARDOSO, P. “As ilhas de Cabo Verde. Um arquipélago do Sahel”. In: Atlas da lusofonia. Volume: Cabo Verde. Lisboa: Instituto Português de Conjuntura Estratégica/Prefácio, 2006. 196 p.

CAROLINO, K. Direitos territoriais das comunidades tradicionais: um estudo de caso da comunidade da ilha de Monte de Trigo, São Sebastião. 2010. 105 p. Dissertação (Mestrado em Ciência Ambiental), Universidade de São Paulo. São Paulo, 2010. Disponível em:

$<$ http://ws1.iee.usp.br/biblioteca/producao/2010/Teses/DissertacaoKatiaCarolino.pdf $>$. Acesso em: $13 / 08 / 2015$.

CARVAlHO, C. M. D. Geographia do Brazil. Tomo I - Geographia Geral. Rio de Janeiro: Empresa Photo-Mechanica do Brazil, 1913. 253 p.

CID, M. C. B. "O Chipre e sua importância geoestratégica durante a Guerra Fria”. Anais do IX ENABED. IX Encontro Nacional da Associação Brasileira de Estudos de Defesa - Forças armadas e sociedade civil: atores e agendas da defesa nacional no século XXI. Eixo temático 6 - História Militar. UFSC, Florianópolis (SC). Publicação: Escola de Comando e Estado-Maior do Exército Marechal Castello Branco. Rio de Janeiro, 2016. 22 p. Disponível em: <http://www.enabed2016. abedef.org/resources/anais/3/1465570268_ARQUIVO_ArtigoChipre.pdf>. Acesso em 05/04/2017. COGNARD, F. “Géohistoire de la Nouvelle-Zélande: unité territoriale et intégration à l'espacemonde". M@ppemonde. Avignon, n 105, v. 1, p. 1-11, 2012. Disponível em: $<$ http://mappemonde.mgm.fr/num33/articles/art12102.html > . Acesso em 09/12/2014.

COUIX, G. e DESSE, M. “Îles tropicales et chorèmes”. M@ppemonde. Avignon, v. 27, n. 3, p. 4346, 1992. Disponível em: <http://www.mgm.fr/PUB/Mappemonde/M392/TROPIQUIL.pdf>. Acesso em 25/09/2016. 
COUTINHO, J. M. V. e MELCHER, G. C. "Levantamento geológico e petrográfico da Ilha do Monte de Trigo (Litoral Norte de São Paulo, Brasil)”. Revista Brasileira de Geociências. São Paulo, v. 3, p. 243-253, 1973.

DANTAS, E. W.. Maritimidade nos trópicos: por uma geografia do litoral. Fortaleza: Edições UFC, 2010. 127 p.

DE MARTONNE, E. Traité de géographie physique. Paris: Armand Colin, 1913. 922 p.

DIEGUES, A. C. "As ilhas e arquipélagos tropicais brasileiros: práticas sociais e simbólicas”. In: . (Org). Ilhas e Sociedades Insulares. São Paulo: NUPAUB-USP, 1997. p. 3-36.

DOMINGO, J. "Le Japon dans le système mondial des échanges de marchandises et de capitaux". M@ppemonde. Avignon, v. 31, n. 3, p. 1-9, 1993. Disponível em: $<$ http://www.mgm.fr/PUB/Mappemonde/M393/JAPON1.pdf>. Acesso em: 16/09/2016.

DOSSE, F. História do estruturalismo. São Paulo: Ensaio, 1993. 110 p. Volume II.

DOUMENGE, F. Geografia dos mares. São Paulo: Difusão Cultural do Livro, 1967. 308 p. Tradução de Octavio Mendes Cajado.

DOUMENGE, F. e MONNIER, Y. Les antilles françaises. Paris: Presses Universitaires de France, 1989. $125 \mathrm{p}$.

DUTENKEFER, E.. Representações do espaço geográfico: mapas dasimétricos, anamorfoses e modelização gráfica. 2010. 140 p. Dissertação (Mestrado em Geografia Humana) - Faculdade de Filosofia, Letras e Ciências Humanas, Universidade de São Paulo, São Paulo. 2010. Disponível em: $\quad<$ http://www.teses.usp.br/teses/disponiveis/8/8136/tde-25022011-115539/.$\quad$ Acesso em: $09 / 12 / 2015$.

ELISSALDE, B. "Situation”. Hypergéo. Spatialité des societés. Rouen, 2004. Disponível em: $<$ http://www.hypergeo.eu/spip.php?article3>. Acesso em 06/09/2014.

ENRICH ROJAS, G. E. Geologia e química mineral da Ilha Monte de Trigo, Litoral Norte do Estado de São Paulo. 2000. 227 p. Dissertação (Mestrado em Mineralogia e Petrologia). Instituto de Geociências, Universidade de São Paulo, São Paulo, 2000.

. Petrogênese da suíte alcalina da Ilha Monte de Trigo, SP. 2006. 229 p. Tese (Doutorado em Mineralogia e Petrologia). Instituto de Geociências, Universidade de São Paulo, São Paulo, 2006. Disponível em: <http://www.teses.usp.br/teses/disponiveis/44/44135/tde04022014-164218/>. Acesso em: 06/08/2015.

ESTRABÃO. Geografía. Madri: Gredos, 1991. Tradução e notas: J. L. García Ramón e J. García Blanco. Volumes I (559 p.) e VIII (566 p.).

EUCLIDES. Elementos. Madri: Gredos, 1991. Volume I. 365 p. Tradução e revisão: Paloma Ortiz. 
ÉVORA, I. "De emigrantes/imigrantes a migrantes transnacionais; possibilidades e limites de uma nova categoria de análise da identidade e migração cabo-verdianas”. In: Anais do III Congresso da APA. Congresso da APA “Afinidade e Diferença”, III. Lisboa: CesA, ISEG, UTL, 10 p., 2006. Disponível em: <http://pascal.iseg.utl.pt/ cesa/files/publicacoes/OP1.pdf > . Acesso em 12/12/2015. FEBVRE, L.. A geographical introduction to history. Londres: Routledge \& Kegan Paul, 1950. 388 p. Tradução de E. G. Mountford e J. H. Paxton.

FOLHA DE SÃO PAULO. Reportagem. Jornal. Caiçaras 'ganham' ilha no litoral norte de SP. De José Benedito da Silva. São Paulo, 2012. Disponível em:

$<$ http://www1.folha.uol.com.br/multimidia/videocasts/2012/01/1028233-caicaras-ganham-ilha-nolitoral-norte-de-sp-veja-video.shtml>. Acesso em 26/08/2015. . Reportagem. Jornal. Seção "Folha Cotidiano". Falta de tudo, menos quem tenha Oliveira no sobrenome. De José Benedito da Silva. São Paulo, 2012. Disponível em: <http:// www1.folha.uol.com.br/fsp/cotidiano/18940-falta-de-tudo-menos-quem-tenha-oliveira-nosobrenome.shtml>. Acesso em 27/08/2015.

FONSECA, F. P. A inflexibilidade do espaço cartográfico, uma questão para a geografia: análise das discussões sobre o papel da cartografia. 2004. 250 p. Tese (Doutorado em Geografia Física) - Faculdade de Filosofia, Letras e Ciências Humanas, Universidade de São

Paulo, São Paulo. 2004. Disponível em: <http://www.teses.usp.br/teses/disponiveis/8/ 8135/tde-09082010-130954/>. Acesso em: 08/11/2015.

FURLAN, S. A. (org.). Ilhas do litoral paulista. São Paulo: CONDEPHAAT/FFLCH-USP, 1989. $49 \mathrm{p}$. "As ilhas do litoral paulista: turismo e áreas protegidas". In: DIEGUES, A. C. Ilhas e Sociedades Insulares. São Paulo: NUPAUB-USP, 1997. p. 37-66.

GAY, J. "La mise em tourisme des ilês intertropicales". M@ppemonde. Avignon, v. 58, n. 2, p. 1722, 2000. Disponível em: <http://www.mgm.fr/PUB/Mappemonde/M200/Gay1.pdf>. Acesso em $17 / 09 / 2016$.

. "La diffusion du tourisme dans l'archipel comorien”. M@ppemonde. Avignon, v. 64, n. 4, p. 15-18, 2001. Disponível em: <http://www.mgm.fr/PUB/Mappemonde/M401/Gay.pdf $>$. Acesso em 17/09/2016.

GIRARDI, E. P. Proposição teórico-metodológica de uma cartografia geográfica crítica e sua aplicação no desenvolvimento do atlas da questão agrária brasileira. 2008. 347 p. Tese (Doutorado em Geografia) - Faculdade de Ciências e Tecnologia, Universidade Estadual Paulista "Júlio de Mesquita Filho", Presidente Prudente. 2008. Disponível em: $<$ https://repositorio.unesp.br/handle/11449/105064>. Acesso em 12/12/2016. 
GONÇALVES, A. F. Avaliação de território e coremática. Aplicação ao município de São Paulo. 2012. 162 p. Dissertação (Mestrado em Geografia Humana) - Faculdade de Filosofia, Letras e Ciências Humanas, Universidade de São Paulo, São Paulo. 2012. Disponível em: $<\mathrm{http}: / /$ www.teses.usp.br/teses/disponiveis/8/8136/tde-10122012-121403/>. Acesso em: $14 / 05 / 2015$.

GONÇALVES, R. L. "Utopia e emigração. Abordagem micro-sociológica na freguesia da Ribeira Quente, São Miguel”. Arquipélago. Revista da Universidade dos Açores. São Miguel, v. 8, n 1, p. 107-132, 1986.

GRATALOUP, C.. "Modélisation graphique”. In: LEVY, J. LUSSAULT, M. (Org.). Dictionnaire de la Géographie et de l'espace des sociétés. Paris: Belin, 2003. p. 629-631. Tradução de Fernanda Padovesi Fonseca e Jaime Tadeu Oliva.

GUÉBOURG, J. "Socotra, une ilê hors du temps”. M@ppemonde. Avignon, v. 57, n. 1, p. 37-43, 2000. Disponível em: <http://www.mgm.fr/PUB/Mappemonde/M100/Guebourg.pdf>. Acesso em $17 / 09 / 2016$.

GUÉBOURG, J. e THÉRY, H. “Une épure de la Réunion”. M@ppemonde. Avignon, v. 11, n. 3, p. 12-13, 1988. Disponível em: <http://www.mgm.fr/PUB/Mappemonde/M388/p12-13.pdf>. Acesso em 18/09/2017.

GUEDES, C. C. F. Evolução sedimentar quaternária da Ilha Comprida, estado de São Paulo. 2009. 133 p. Dissertação (Mestrado em Geotectônica) - Instituto de Geociências, Universidade de São Paulo, São Paulo. 2009. Disponível em: $<$ http://www.teses.usp.br/teses/disponiveis/44/44141/tde-14102009-085840/pt-br.php>. Acesso em $14 / 08 / 2016$.

GUERRA, A. T. Dicionário Geológico-Geomorfológico. Rio de Janeiro: IBGE, 1993. 446 p.

HAGGETT, P. e CHORLEY, R.. "Modelos, paradigmas e a Nova Geografia" In: . (Org.). Modelos físicos e de informação em Geografia. São Paulo: Edusp, 1975. p. 1-19. Tradução de Arnaldo Viriato de Medeiros.

HANSEN, B. U. "Monitoring natural vegetation in Southern Greenland using NOAA AVHRR and field measurements". Arctic Journal. Calgary, University of Calgary, Arctic Institute of North America, v. 44, sup. 1, p. 94-101 1991. Disponível em: $<$ http://pubs.aina.ucalgary.ca/arctic/Arctic44-S-94.pdf>. Acesso em 04/09/2016

HARVEY, D. Explanation in Geography. Londres: Edward Arnold, 1973. 521 p.

HAYES, B. "Graph theory in practice". Part I. American scientist. Chapel Hill, Carolina do Norte, v. $88,2000$. 
HORWITZ, T. Blue latitudes. Boldly going where Captain Cook has gone before. Nova York: Henry Holt and Co., 2003. 453 p.

IBGE. Instituto Brasileiro de Geografia e Estatística. Manual Técnico de Geomorfologia. Rio de Janeiro: IBGE, 2009. 174 p.

. Manual Técnico da Vegetação Brasileira. Rio de Janeiro: IBGE, 2012. 271 p.

. Manual Técnico de Uso da Terra. Rio de Janeiro: IBGE, 2013. 170 p.

. Manual Técnico de Pedologia. Rio de Janeiro: IBGE, 2015. 430 p.

IBGE. Instituto Brasileiro de Geografia e Estatística e MB. Marinha do Brasil. Atlas geográfico das zonas costeiras e oceânicas do Brasil. Rio de Janeiro: IBGE, 2011. 176 p.

JADÉ, E. “Organisation spatiale d'île de Ténériffe”. M@ppemonde. Avignon, v. 60, n. 4, p. 29-32,

2000. Disponível em: <http://www.mgm.fr/PUB/Mappemonde/M400/Jade.pdf $>$. Acesso em $17 / 09 / 2016$.

JAUZE, J. "L'île de La Réunion: deux modèles de la dynamique spatiale des villes". M@ppemonde. Avignon, v. 42, n. 2, p. 32-43, 1996. Disponível em: $<$ http://www.mgm.fr/PUB/Mappemonde/M296/Jauze.pdf>. Acesso em 18/09/2017.

JOLY, F. A cartografia. Campinas: Papirus, 1990. 136 p. Tradução: Tânia Pellegrini.

KASPEROVICZUS, K. N. e ALMEIDA-SANTOS, S. M. "Instituto Butantan e a jararaca-ilhoa: cem anos de história, mitos e ciência". Cadernos de História da Ciência. São Paulo, v. 8, nº 2, 2012. Disponível em: $<$ http://periodicos.ses.sp.bvs.br/scielo.php?script=sci_arttext\&pid=S180976342012000200005\&lng=es\&nrm=iso>. Acesso em 17/06/2016.

KLUGE, P. F. "Oceanos e ilhas". In: NATIONAL GEOGRAPHIC SOCIETY. Atlas National Geographic. São Paulo: Abril, 2008. Volume 18. Oceanos e o Universo em imagens. 96 p.

KNAFOU, R. "Le tourisme à la Réunion et à Maurice". M@ppemonde. Avignon, v. 11, n. 3, p. 911, 1988. Disponível em: <http://www.mgm.fr/PUB/Mappemonde/M388/p9-11.pdf>. Acesso em $18 / 09 / 2016$.

KONINCK, R. e THÉRY, H. "Les quatre faces de La Malaisie: structure et dynamique". M@ppemonde. Avignon, v. 15, n. 3, p. 40-43, 1989. Disponível em: <http://www.mgm.fr/ PUB/Mappemonde/M389/p40-43.pdf>. Acesso em 16/09/2016.

LA BLACHE, P. V. Princípios de geografia humana. Volume I. Lisboa: Cosmos, 1921. 387 p. Tradução, notas e prefácio: Fernandes Martins. Original póstumo publicado por Emmanuel De Martonne.

LÉVI-STRAUSS, C. Antropologia estrutural. Volume I. Rio de Janeiro: Tempo Brasileiro, 1962. 456 páginas. Tradução: Chaim Samuel Katz e Eginardo Pires. 
. Antropologia estrutural. Volume II. Rio de Janeiro: Tempo Brasileiro, 1973. 366 p.

Tradução e coordenação de Maria do Carmo Pandolfo.

LIBAULT, A. Geocartografia. São Paulo: Nacional/Edusp, 1975. 388 p.

LIMA, G. G. Pesca artesanal e conservação do meio marinho: atividade pesqueira dos monteiros. São Paulo. 2014. 75 p. Trabalho de Graduação Individual (Bacharelado em Geografia). Faculdade de Filosofia, Letras e Ciências Humanas. Universidade de São Paulo. São Paulo, 2014. LING, A. Golden dreams of Borneo. Bloomington (Indiana): Xlibris Co., 2013. 326 p. LOBATO, M. Os faroleiros. In: . Urupês. São Paulo: Brasiliense, 1994. p. 19-25.

LOPES, B. O dialecto crioulo em Cabo Verde. Lisboa: Imprensa Nacional/Coroa da Moeda, 1984. $391 \mathrm{p}$.

LUSSAULT, M. “Imagem”. In: LÉVY, J. e LUSSAULT, M. (Org.). Dictionnaire de la géographie et de l'espace des societés. Paris: Belin, 2003, p. 485-489. Tradução de trabalho de Fernanda Padovesi Fonseca e Jaime Tadeu Oliva.

MACARTHUR, R. H. e WILSON, E. O. The theory of island biogeography. Princeton (Nova Jersey): Princeton University Press, 2001. 203 p.

MARANHÃO. Constituição do Estado do Maranhão. São Luís, 05 de outubro de 1989. Edição SUSUCI/CGE/MA. Publicação e atualização até a Emenda Constitucional no 69 de 12/02/2014 pela Secretaria de Estado de Transparência e Controle (STC). Disponível em: $<$ http://www.stc.ma.gov.br/files/2013/03/CONSTITUI\%C3\%87\%C3\%83O-DO-ESTADO-DOMARANH\%C3\%83O_atualizada_at\%C3\%A9_emenda69.pdf>. Acesso em 10/05/2017. MARTINELli, M. Curso de Cartografia Temática. São Paulo: Contexto, 1991. 180 p. MAZZINI, P. L. F. Correntes subinerciais na Plataforma Continental interna entre Peruíbe e São Sebastião: observações. 2009. 112 p. Dissertação (Mestrado em Oceanografia Física). Instituto Oceanográfico, Universidade de São Paulo. São Paulo, 2009.

MERCIER, G. “Etude de l'insularité (rapport sur le premier thème)”. Norois. Poitiers, v. 37, $\mathrm{n}^{0}$ 145, 9-14, 1990.

MERLEAU-PONTY, M. Fenomenologia da percepção. São Paulo: Martins Fontes, 1999. 465 p. Tradução de Carlos Alberto Ribeiro de Moura.

MILANESI, M. A. Avaliação do efeito orográfico na pluviometria de vertentes opostas da Ilha de São Sebastião (Ilhabela-SP). 2007. 141 p. Dissertação (Mestrado em Geografia Física) Faculdade de Filosofia, Letras e Ciências Humanas, Universidade de São Paulo, São Paulo, 2007. MOLES, A. e ROHMER, E. Labyrinthes de vécu. L'Espace: matière d'actions. Paris: Librairie des meridiens, 1982. 183 p. 
MOTOKI, A. Geologia e petrologia do maciço alcalino da ilha da Vitória, SP. 1986. 244 p. Tese (Doutorado em Mineralogia e Petrologia). Instituto de Geociências, Universidade de São Paulo. São Paulo, 1986. Disponível em:

$<$ http://www.iaea.org/inis/collection/NCLCollectionStore/_Public/25/048/25048909.pdf $>$. Acesso em 03/09/2015.

NATIONAL GEOGRAPHIC. Atlas National Geographic. Volume 6. América do Norte e Central. São Paulo: Abril, 2008. 112 p.

. Atlas National Geographic. Volume 10. África. Tomo II. São Paulo: Abril, 2008. $96 \mathrm{p}$.

NÉMETH, P. S. Glossário caiçara de Ubatuba. Pequeno vocabulário de palavras e locuções que compõem o falar do povo caiçara do litoral norte de São Paulo. São Paulo: All Print, 2010. 129 p.

NEYROUD, M. "Sri Lanka: modèle d'île”. M@ppemonde. Avignon, v. 31, n. 3, p. 1-6, 1993.

Disponível em: <http://www.mgm.fr/PUB/Mappemonde/M393/SRILANKA.pdf>. Acesso em $16 / 09 / 2016$.

ONU. Organização das Nações Unidas. Convenção das Nações Unidas sobre o Direito do Mar. Montego Bay, Jamaica, 10 de dezembro de 1982. Em vigor pelo Decreto Federal $\mathrm{n}^{\circ} 1.530$. Brasília 22 de junho de $1995 . \quad$ Disponível em: $<$ https://www.egn.mar.mil.br/arquivos/cursos/csup/CNUDM.pdf $>$. Acesso em 09/09/2015.

PANIZZA, A. C. "O litoral do Rio Grande do Norte: dinâmica e modelo espacial”. Confins. Revista Franco-Brasileira de Geografia. Paris/São Paulo, n 3, 2008. Disponível em:

$<$ http://confins.revues.org/3473\#tocto1n1 $>$. Disponível em: $<01 / 02 / 2015>$.

PANIZZA, A. C. e FONSECA, F. P. "Técnicas de interpretação visual de imagens". GEOUSP Espaço e Tempo. São Paulo, $\mathrm{n}^{\circ}$ 30, pp. 30-43, 2011. Disponível em: $<$ http://www.revistas.usp.br/geousp/article/view/74230/77873>. Acesso em 02/10/2017.

PANIZZA, A. C.; FOURNIER, J; LUCHIARI, A. “L'urbanisation littorale au Brésil: Ubatuba (São Paulo)”.M@ppemonde. Avignon, v. 73, n. 1, p. 1-9, 2004. Disponível em: <http://mappemondearchive.mgm.fr/num1/articles/art04107.html>. Acesso em 25/09/2016.

PELLETIER, P. "La distance japonésienne, unne approche géohistorique et géoculturelle”. Atala. Paris, v. 12, Edição “La distance, objet géographique”, p. 229-246, 2009. Disponível em: $<$ http://www.lycee-chateaubriand.fr/cru-atala/publications/ATALA12/PelletierAtala12.pdf $>$. Acesso em 09/10/2015.

PEREIRA, C. S.; NOVAES JÚNIOR, R. A.; CUNHA, A. B. P. V.; MARIANO, L. Mapeamento e caracterização sócio-ambiental das ilhas ocupadas do litoral norte do Estado de São Paulo. 
São José dos Campos: INPE, 2009. Disponível em: <http://urlib.net/sid.inpe.br/mtcm19@80/2009/12.01.11.56>.Acesso em 18/08/2015.

PÉRON, F. Des îles et des Hommes, l'insularité aujourd'hui. Paris: Éditions de la Cité, 1993. $286 \mathrm{p}$.

PLATÃO. "Fédon ou da alma". In:

Diálogos. São Paulo: Abril Cultural, 1999. p. 115-190.

PONCET, P. “Quel fond de carte pour l'Australie?”. M@ppemonde. Avignon, n 74, v. 2, p. 1-18, 2004. Disponível em: <http://mappemonde.mgm.fr/num2/articles/art04206.html>. Acesso em $09 / 12 / 2014$.

RATZEL. F. Geografia. São Paulo: Ática, 1990. 199 p. Organização: Antonio Carlos Robert de Moraes.Tradução: Fátima Murad e Denise Bottman.

REINO UNIDO. Ministério da Justiça. Gabinete de Dependências da Coroa. Fact sheet on the UK's relationship with the Crown Dependencies. Londres, 2014. Disponível em: $<$ https://www.gov.uk/government/uploads/system/uploads/attachment_data/file/564373/factsheeton-the-uks-relationship-with-the-crown-dependencies.pdf>. Acesso em 11/02/2017.

ROBINSON, H. E. Biogeography. Aspect Geographies. Londres: McDonald \& Evans Ltda, 1972. $560 \mathrm{p}$.

ROCHA, R. M.; DIAS, G. M. D.; LOTUFO, T. M. C.. "Checklist das ascídias (Tunicata, Ascidiacea) do Estado de São Paulo, Brasil”. Biota Neotropica. São Paulo, v. 11, suplemento 1, p. 749-759, 2011. Disponível em: <http://www.biotaneotropica.org.br/v11n1a/en/abstract?inventory +bn0391101a2011>. Acesso em 03/09/2015.

ROYLE, S. A. A geography of islands: small islands insularity. Londres e Nova York: Routledge, 2001.237 p.

RÜE, E. A.. L'homme et les îles. Paris: Gallimard, 1935. 194 p.

SÃO SEBASTIÃO. Lei Orgânica do Município de São Sebastião, Estado de São Paulo. São Sebastião (SP), $1999 . \quad$ Disponível em: $<$ http://www.camarasaosebastiao.com.br/site2013/site/upload/upleisorganicas/a1a71696ddedfb7167 9976aa11595ae1.pdf $>$. Acesso em 21/08/2015.

Plano Diretor do Município de São Sebastião. São Sebastião (SP), 2007. Disponível em <http://www.saosebastiao.sp.gov.br/finaltemp/planodiretor/pd_30_08_07/pl_pd_30_ 082007.pdf $>$. Acesso em 21/08/2015.

SÃO PAULO. Conselho de Defesa do Patrimônio Histórico, Arqueológico, Artístico e Turístico do Estado de São Paulo (Condephaat). Resolução SC 40. São Paulo, 06 de junho de 1985. Publicada no Diário Oficial Estadual (DOE) em 15/06/1985. Disponível em: 
$<$ http://www.prefeitura.sp.gov.br/cidade/upload/db122_RES.\%20SC\%20N\%2040\%20-\%20Area $\% 20 \mathrm{da} \% 20$ Serra\%20do\%20Mar\%20e\%20Paranapiacaba.pdf $>$. Acesso em 11/09/2015.

Constituição do Estado de São Paulo. São Paulo, 05 de outubro de 1989.

Disponível em: <http://www.legislacao.sp.gov.br/legislacao/dg280202.nsf/a2dc3f553380ee 0f83256cfb00501463/46e2576658b1c52903256d63004f305a?OpenDocument>. Acesso em 08/09/2015.

. Decreto Estadual $n^{\circ}$ 53.525. São Paulo, 8 de outubro de 2008. Disponível no repositório da Assembleia Legislativa do Estado de São Paulo, em: <http://www.al.sp.gov.br/ repositorio/legislacao/decreto/2008/decreto-53525-08.10.2008.html>. Acesso em 09/09/2015.

SÃO TOMÉ E PRÍNCIPE. Assembleia Nacional de São Tomé e Príncipe. Constituição da República Democrática de São Tomé e Príncipe. Promulgação em 25 de janeiro de 2003. Disponível em: <http://www.parlamento.st/>. Acesso em 23/02/2017.

SARTORELLO, R. Ilhas do litoral norte do estado de São Paulo: paisagem e conservação. 2010. 160 p. Dissertação (Mestrado em Geografia Física) - Faculdade de Filosofia, Letras e Ciências Humanas, Universidade de São Paulo, São Paulo, 2010. Disponível em: $<$ http://www.teses.usp.br/teses/disponiveis/8/8135/tde-19072010-135902/>. Acesso em: $10 / 08 / 2015$.

SAUSSURE, F. Curso de linguística geral. São Paulo: Cultrix, 1975. 280 p.

SEMPLE, E. C.. Influences of geographic environment on the basis of Ratzel's system of anthropo-geography. Londres: Constable \& Company, 1941. 683 p.

SILVA, I. M. C.. A rede que pesca gente: o caso da comunidade Cajueiro na ilha de Mosqueiro/PA. 2015. 96 P. Dissertação de Mestrado. Programa de Pós-Graduação em Ecologia Aquática e Pesca do Instituto de Ciências Biológicas da Universidade Federal do Pará. Belém (PA), 2015. Disponível em: $\quad<$ http://ppgeap.propesp.ufpa.br/ARQUIVOS/dissertacoes/2015/PPGEAP_Dissertacao_ ISABELLE\%20MARIA\%20DAS\%20CHAGAS\%20SILVA.pdf>. Acesso em 20/10/2016.

SILVA, L. C. Análise da dinâmica das pescarias na enseada de Caraguatatuba e arquipélago de Ilhabela (São Paulo, Brasil) e a influência de fatores ambientais sobre sua produtividade. 2014. 68 p. Dissertação (Mestrado em Aquicultura e Pesca). Instituto de Pesca, Agência Paulista de Tecnologia dos Agronegócios, Secretaria de Agricultura e Abastecimento do Governo do Estado de São Paulo. São Paulo, 2014. Disponível em: <ftp://ftp.sp.gov.br/ftppesca/Disserta14LuisaCandancan_daSilva.pdf>. Acesso em 03/09/2015.

SPINELLI, F. P. As rochas alcalinas de Cananeia, litoral sul do Estado de São Paulo: estudos mineralógicos, geoquímicos e isotópicos. 2007. 139 p. Tese (Doutorado em Petrologia Ígnea e Metamórfica). Instituto de Geociências, Universidade de São Paulo. São Paulo, 2007. 
TEIXEIRA, S. G. e MARTINS E SOUZA FILHO, P. W. "Mapeamento de ambientes costeiros tropicais (Golfão Maranhense, Brasil) utilizando imagens de sensores remotos orbitais". Revista Brasileira de Geofísica. São Paulo, v. 27, supl. 1, 2009. Disponível em: $<$ http://www.scielo.br/scielo.php?script=sci_arttext\&pid=S0102-261X2009000500006>. Acesso em $10 / 05 / 2017$.

TERAMOTO, C. S. Conflitos entre pescadores artesanais e amadores em Bertioga/SP e adjacências. 2014. 101 p. Dissertação (Mestrado em Ciência Ambiental). Instituto de Energia e Eletrotécnica, Universidade de São Paulo. São Paulo, 2014. Disponível em:

$<$ http://200.144.182.130/iee/sites/default/files/Carolina\%20Sayuri\%20Teramoto.pdf $>$.

Acesso em: 03/09/2015.

THÉRY, H. "Modelização gráfica para a análise regional: um método”. Geousp. Espaço e Tempo. São Paulo, n 15, p. 179-188, 2004.

. “A dimensão temporal na modelização gráfica”. Geousp. Espaço e Tempo. São Paulo, $\mathrm{n}^{\circ} 17$, p. 171-183, 2005.

THIERRY, N. “'L'Hypo-insularité', une nouvelle condition insulaire: l'exemple des Antilles françaises”. Espace géographique. Paris, nº 4, p. 329-241, 2005.

TUAN, Y. Topofilia: um estudo da percepção, atitudes e valores do meio ambiente. São Paulo: DIFEL, 1980. 288 p. Tradução: Lívia de Oliveira.

. Espaço e lugar: a perspectiva da experiência. São Paulo: Difel, 1983. 250 p. Tradução: Lívia de Oliveira.

VEJA SÃO PAULO. Reportagem. Revista. Moradores de ilhas do litoral paulista vivem no isolamento. De Angela Pinho. Seção "Praia". São Paulo, 2014. Disponível em: $<$ http://vejasp.abril.com.br/materia/moradores-das-ilhas-isoladas-do-litoral-paulista/>. Acesso em $27 / 08 / 2015$.

WALLACE, A. R. Island life or the phenomena and causes of insular faunas and floras including a revision and attempted solution of the problem of geological climates. N. York: AMS, 1975. 563 p. WHITTAKER, R. J. \& FERNÁNDEZ-PALACIOS, J. M. Island biogeography: ecology, evolution and conservation. Oxford: Oxford University Press, 2008. 401 p.

WITHERICK, M.; ROSS, S.; SMALL, J. A modern dictionary of Geography. Londres: Arnold/Nova York: Oxford University Press, 2001. 293 p. 


\section{B. ELETRÔNICAS}

AOSIS. Alliance of Small Island States. Disponível em: $<$ http://aosis.org/>. Acesso em 06/06/2016.

BRASIL MERGUlHO. Montão de Trigo. Reportagem da Redação. 10/04/2000. Disponível em: $<$ http://www.brasilmergulho.com/port/points/sp/montao_trigo.shtml >. Acesso em 03/03/2015.

CABO VERDE. Instituto Nacional de Estatística. Disponível em: <http://www.ine.cv/>. Acesso em 03/02/3017.

CHILE. Instituto Nacional de Estatísticas. Disponível em: <http://www.ine.cl/>. Acesso em 20/02/2017.

CIA. Central Intelligence Agency. The World Factbook. Publicações com atualizações até 2016. Disponível em: $\quad<$ https://www.cia.gov/library/publications/the-world-factbook/geos/nr.html $>$. Acesso em 04/07/2016. Verbetes consultados: Australia; Comoros; Greenland; Mauritius; Micronesia, Federated States of; Nauru; Philippines; Saint Helena, Ascencion and Tristan da Cunha; Saint Lucia; Singapure; Tuvalu.

EMPLASA. Empresa Paulista de Planejamento Metropolitano S.A. Projeto de Atualização Cartográfica do Estado de São Paulo - Projeto "Mapeia São Paulo". 2010, 2011. Disponível em: $\quad<$ https://www.emplasa.sp.gov.br/ProjetoMapeia/Sistema-Mapeia-Sao-Paulo>. Acesso em 07/12/2016.

ESPÍRITO SANTO. Companhia Docas do Espírito Santo. CODESA. Disponível em: $<$ http://www.vitoriaport.com.br/site/>. Acesso em 23/04/2016.

ESRI. Environment Systems Research Institute. Disponível em: $<$ http://www.esri.com/>. Acesso em 09/12/2015.

IBGE. Instituto Brasileiro de Geografia e Estatística. Censo Demográfico 2010. Sistematização de dados: 2015. Disponível em: <http://www.ibge.gov.br/home/estatistica/populacao/ censo2010/resultados_gerais_amostra/resultados_gerais_amostra_tab_uf_microdados.shtm>. Acesso em 31/08/2015.

Cidades. Portal eletrônico. Disponível em: <https://cidades.ibge.gov.br/xtras/ home.php?lang=>. Acesso em 11/02/2017.

. Limites Estaduais do Brasil. 2010. Disponível em: $<$ https://mapas.ibge.gov.br/basese-referenciais/bases-cartograficas/malhas-digitais.html>. Acesso em 06/12/2016.

Mapeamento Sistemático Brasileiro. Carta Topográfica SF-23-Y-D-V-1 (Folha

Salesópolis). Disponível em: $\quad<$ http://biblioteca.ibge.gov.br/visualizacao/mapas/GEBIS\%20\%20RJ/SF-23-Y-D-V-1.jpg>. Acesso em 13/12/2014. 
. Mapeamento Sistemático Brasileiro. Carta Topográfica SF-23-Z-C-II-2 (Folha Ilha

Grande). Disponível em: <http://biblioteca.ibge.gov.br/visualizacao/mapas/GEBIS\%20-\%20RJ/SF23-Z-C-II-2.jpg>. Acesso em 19/04/2016.

. Mapeamento de Unidades Territoriais. 2010. Disponível em: $<$ http://www.ibge. gov.br/home/geociencias/cartografia/default_territ_int.shtm?c=3>. Acesso em 23/10/2016.

IGC. Instituto Geográfico e Cartográfico. Limites Municipais do Estado de São Paulo. 2015. Disponível em: <http://www.igc.sp.gov.br/servicos/demarcacao.html>. Acesso em 06/12/2016.

ISLÂNDIA. Vegagerdin. Administração Viária e Costeira da Islândia. Disponível em: $<$ http://www.road.is/>. Acesso em 20/02/2017.

M@PPEMONDE. Revue M@ppemonde. Disponível em: <http://mappemonde.mgm.fr/>. Acesso em 12/12/2016.

OPEN STREET MAP. Plataforma Open Street Map. Disponível em: $<$ https://www.openstreetmap.org/\#map=10/33.9018/131.8716>. Acesso em 26/01/2017.

PNUD. Programa das Nações Unidas para o Desenvolvimento. Conferência dos Pequenos Estados Insulares em Desenvolvimento. 2014. Disponível em: $<$ http://www.undp.org/content/undp/fr/home/presscenter/events/2014/september/smallislands2014.h tml>. Acesso em 06/06/2016.

PORTUGAL. Instituto Nacional de Estatística. Disponível em: $<$ https://www.ine.pt $>$. Acesso em $03 / 02 / 2017$.

UNIÃO EUROPEIA. Rede Europeia de Migração (EMN). Disponível em: $<$ http://emn.ie/index.jsp?p=128\&n=229>. Acesso em 22/04/2017. 